\title{
Dysertacje
}

Wydziału Neofilologii UAM w Poznaniu

Marta Olga Janik

Adjektivbøyning i norsk - kongruenstilegnelse hos polskspråklige norskinnlærere

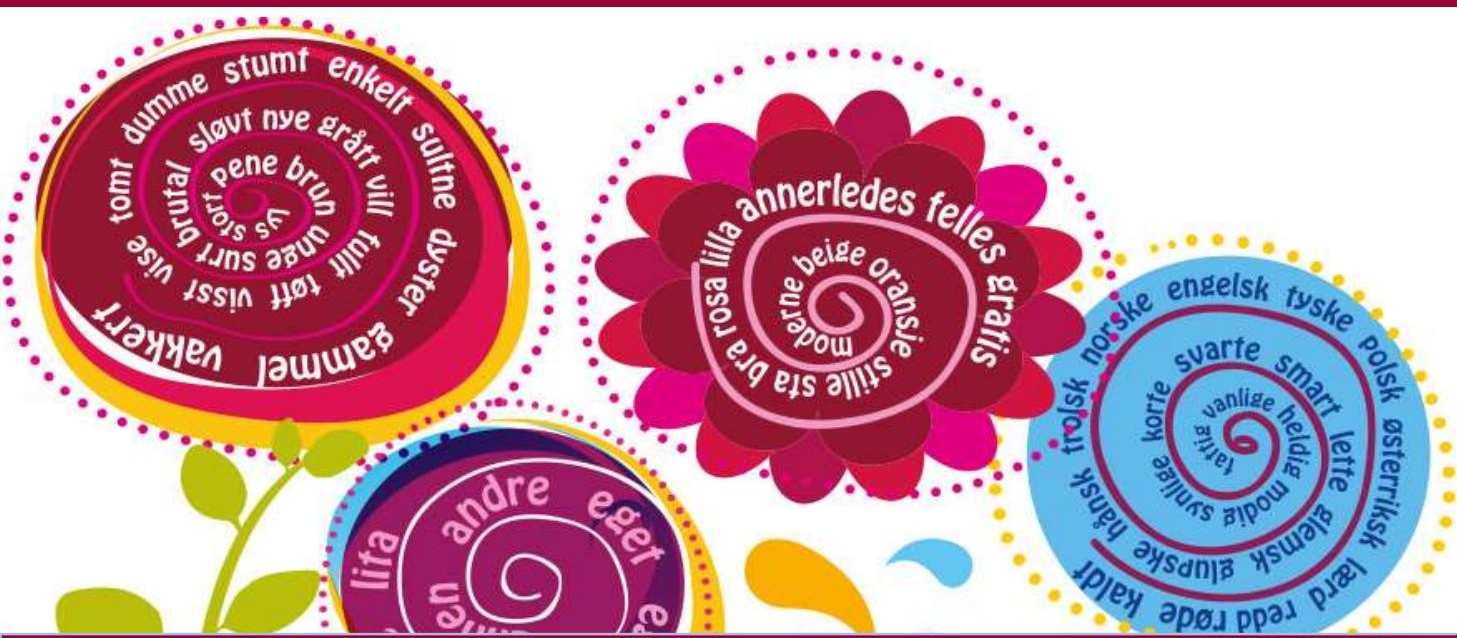





\section{Adjektivbøyning i norsk - kongruenstilegnelse hos polskspråklige norskinnlærere}





\section{Marta Olga Janik}

\section{Adjektivbøyning i norsk - kongruenstilegnelse hos polskspråklige norskinnlærere}

Wydział Neofilologii UAM w Poznaniu

Poznań 2016 
Projekt okładki:

Marta Olga Janik

Wykonanie projektu:

Urszula Wasilczuk

Recenzja:

dr hab. Witold Maciejewski

Copyright by:

Marta Olga Janik

Wydanie I, Poznań 2016

\section{ISBN 978-83-947198-8-3}

*DOI: $10.14746 / 9788394719883 *$

Wydanie:

Wydział Neofilologii UAM w Poznaniu al. Niepodległości 4, 61-874 Poznań e-mail: dziekneo@amu.edu.pl www.wn.amu.edu.pl 


\section{Innholdsfortegnelse}

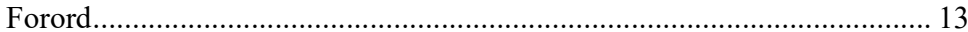

1 Innledning .................................................................................... 15

1.1 Teoretisk utgangspunkt og formålet med avhandlingen ..................... 17

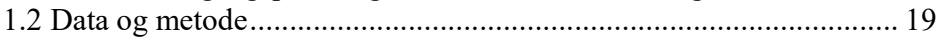

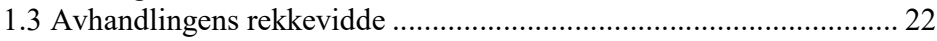

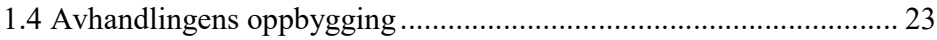

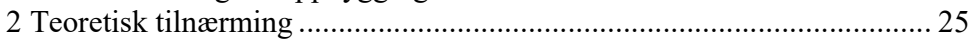

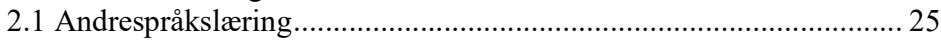

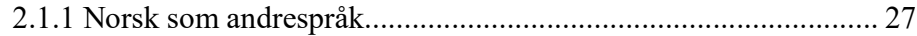

2.2 Kognitive teorier om andrespråkslæring.......................................... 28

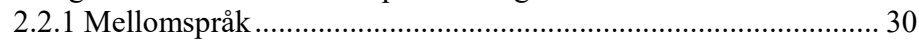

2.2.2 Transfer................................................................................ 31

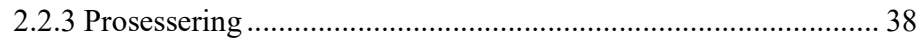

2.2.4 Utviklingsmønstre i mellomspråk ................................................ 44

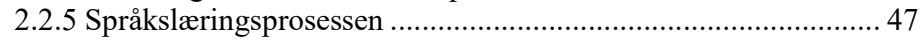

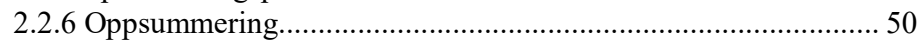

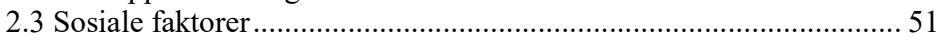

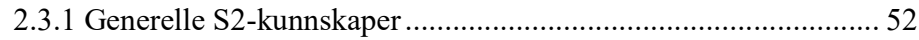

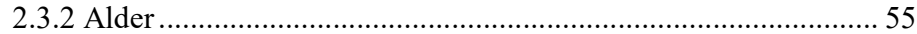

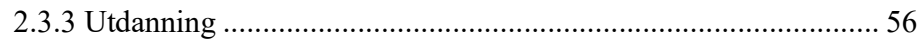

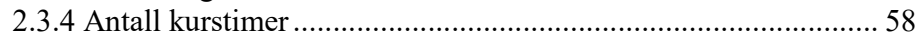

2.3.5 Oppholdstid i S2-landet og daglig bruk av S2 ............................. 60

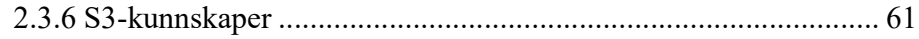

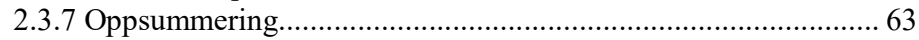

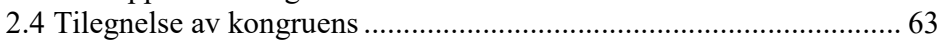

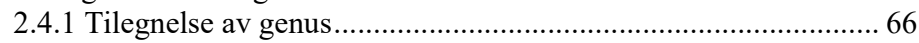

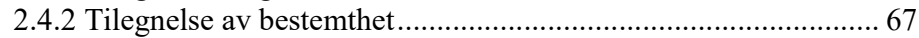

2.4.3 Tilegnelse av adjektivets semantikk........................................... 68

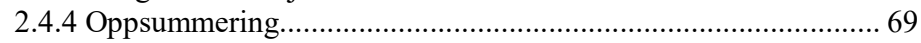

2.5 Hypoteser og forskningsspørsmål.................................................... 70

3 Adjektiver og kongruens ...................................................................... 74

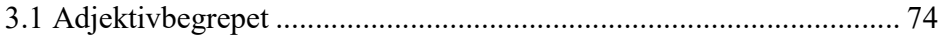

3.1.1 Adjektiv som en av ordklassene................................................ 74

3.1.2 Adjektiver i norske grammatikker ............................................. 76

3.1.3 Adjektiver i polske grammatikker............................................... 83

3.1.4 Adjektiver i engelske grammatikker .......................................... 85

3.1.5 Adjektiver i tyske grammatikker................................................. 86

3.1.6 En prototypedefinisjon av adjektivklassen i norsk ...................... 87

3.1.6.1 Adjektiver vs. substantiver ................................................... 92

3.1.6.2 Adjektiver vs. adverb ........................................................ 93

3.1.6.3 Adjektiver vs. partisipper .................................................... 94

3.1.6.4 Adjektiver vs. possessiver ..................................................... 95 
3.1.6.5 Adjektiver vs. ordenstall ................................................ 95

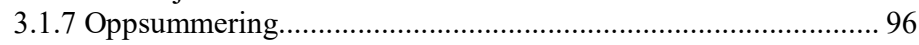

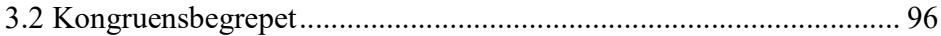

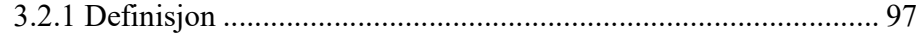

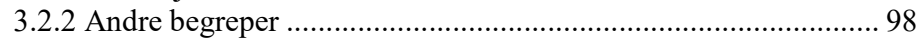

3.3 Egenskaper ved adjektiver ...................................................... 101

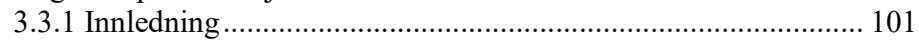

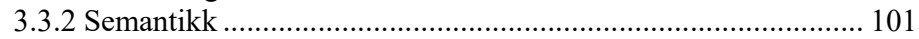

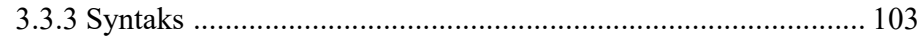

3.3.3.1 AP - funksjon i setningen ............................................ 104

3.3.3.1.1 Adledd i NP ........................................................... 104

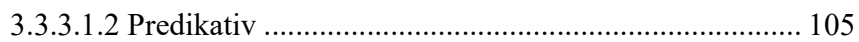

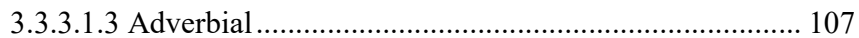

3.3.3.1.4 Adledd i AP .......................................................... 108

3.3.3.2 AP - interne struktur ................................................... 108

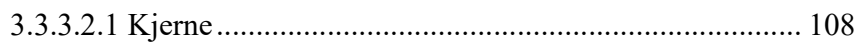

3.3.3.2.2 Premodifikator.......................................................... 110

3.3.3.2.3 Postmodifikator ..................................................... 112

3.3.4 Morfologi............................................................................ 115

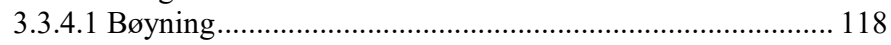

3.3.4.1.1 Hovedregelen...................................................... 118

3.3.4.1.2 Modifikasjoner av hovedregelen ............................. 120

3.3.4.1.3 Avvikende bøyning ............................................... 123

3.3.4.2 Bruk av formene...................................................... 128

3.3.4.2.1 Adjektiver $i$ attributiv stilling ................................... 129

3.3.4.2.2 Adjektiver i predikativ stilling................................. 132

3.3.4.2.3 Adjektiver i adverbialfunksjonen og som adledd i AP 134

3.3.5 Samsvarsbøyning i norske målformer og dialekter .................. 135

3.3.5.1 Bokmål og nynorsk ...................................................... 135

3.3.5.2 Dialektale forskjeller ....................................................... 136

3.3.6 Adjektivbøyning i polsk, engelsk og tysk ............................. 137

3.3.6.1 Adjektivbøyning i polsk ............................................... 137

3.3.6.2 Adjektivbøyning $i$ engelsk ........................................... 139

3.3.6.3 Adjektivbøyning i tysk ................................................. 140

3.3.6.4 Sammenlikning med norsk.............................................. 141

3.3.7 Oppsummering ................................................................ 142

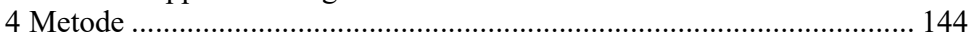

4.1 Korpuslingvistikk ....................................................................... 144

4.2 Datamaterialet...................................................................... 148

4.2.1 ASK-korpuset ............................................................. 148

4.2.2 Informanter - innlærervariabler ......................................... 150

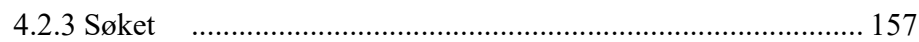

4.2.4 Bearbeidelsen av data ........................................................ 158

4.3 Kvantitative /statistiske metoder................................................ 161

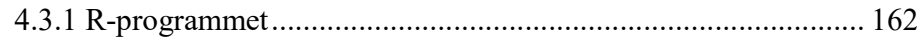




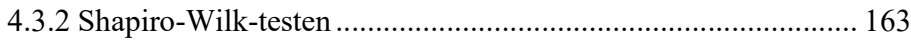

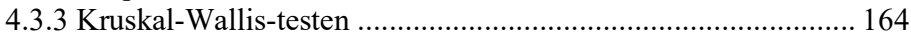

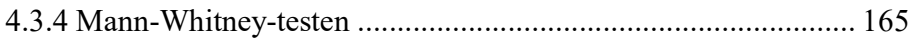

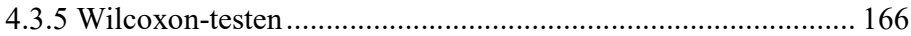

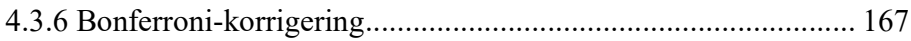

4.4 Metoden i transferanalysen.......................................................... 167

4.4.1 Intragruppe-homogenitet......................................................... 168

4.4.2 Intergruppe-heterogenitet..................................................... 170

4.4.3 Tverrspråklig performansesamsvar......................................... 172

4.4.4 Innenspråklige ulikheter...................................................... 173

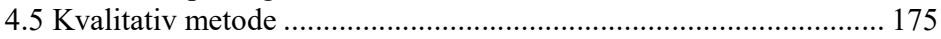

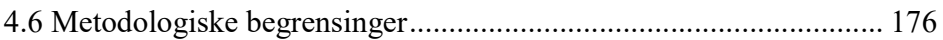

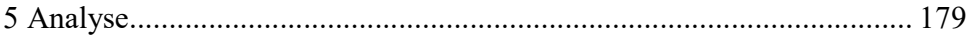

5.1 Samsvarsbøyning av adjektiver i de polskspråkliges mellomspråk . 180

5.1.1 Mangel på kongruens............................................................. 182

5.1.1.1 Mangel på -t-endelse .......................................................... 184

5.1.1.2 Mangel på -e-endelse …………………………………....... 188

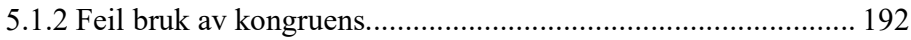

5.1.2.1 Overbruk av -t-endelse ...................................................... 194

5.1.2.2 Overbruk av -e-endelse ..................................................... 196

5.1.3 Feil bruk av kongruensendelse................................................. 199

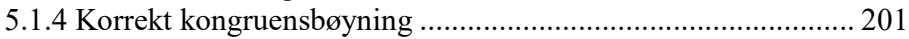

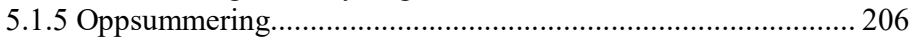

5.2 Påvirkning av sosiale faktorer på de polskspråkliges

performanse i norsk samsvarsbøyning............................................ 207

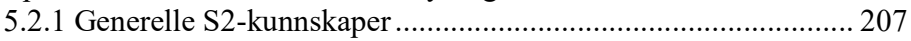

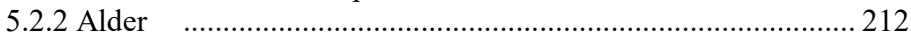

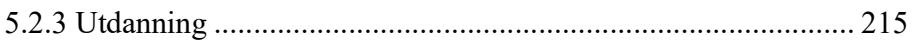

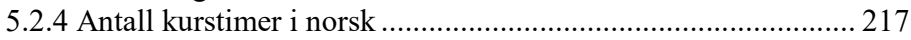

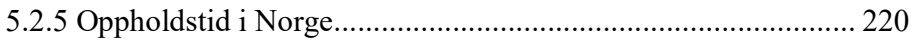

5.2.6 Kunnskaper i engelsk som S3 ............................................... 222

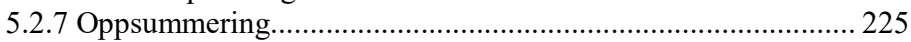

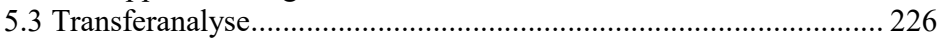

5.3.1 Intragruppe-homogenitet og intergruppe-heterogenitet............. 234

5.3.2 Tverrspråklig performansesamsvar.......................................... 235

5.3.2.1 Mangel på kongruens …………………………….............. 237

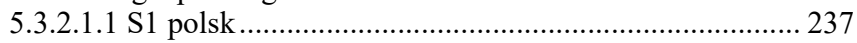

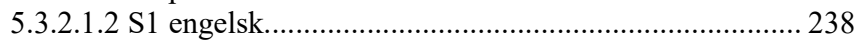

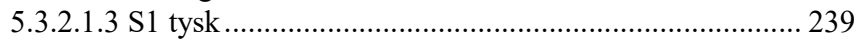

5.3.2.2 Feil bruk av kongruens .................................................... 241

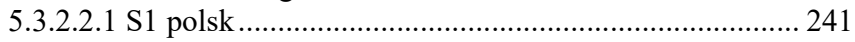

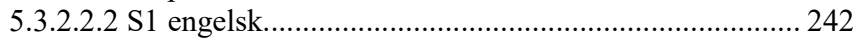

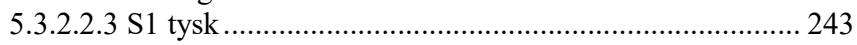

5.3.2.3 Feil kongruensendelse ...................................................... 244

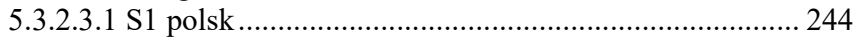


5.3.2.3.2 S1 engelsk............................................................... 245

5.3.2.3.3 S1 tysk ................................................................... 247

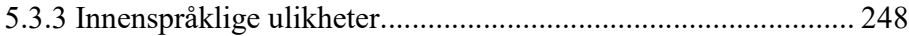

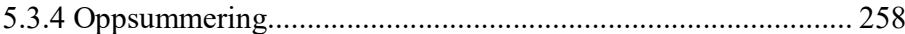

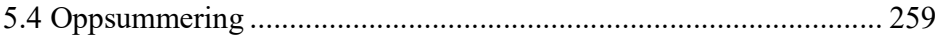

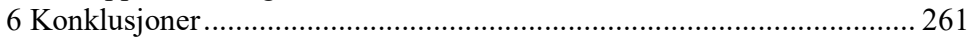

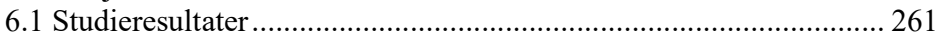

6.1.1 Adjektiver brukt ukorrekt av innlærerne ................................... 261

6.1.2 Den grammatiske konteksten til kongruens ............................. 262

6.1.3 Den psykolingvistiske faktoren - transfer .................................. 268

6.1.4 De sosiale faktorene.............................................................. 274

6.2 Konklusjoner for didaktiske formål ............................................... 277

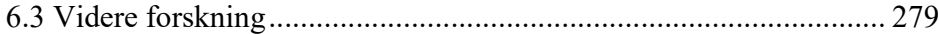

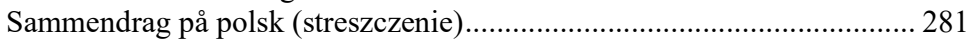

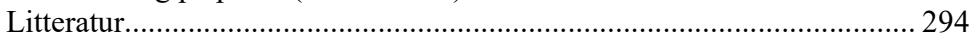

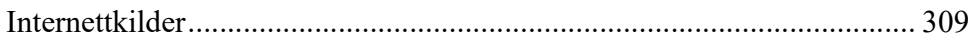

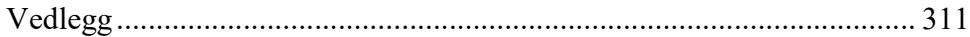




\section{Liste over tabeller}

Tabell 1: Et vanskehierarki av kontrastene som oppstår som et resultat av en kontrastiv analyse av to språk............................................ 33

Tabell 2: Fordelingen av endelsene ved norske adjektiver ....................... 119

Tabell 3: Anvendelse av norske samsvarsbøyningsendelser ved adjektiver........................................................................ 119

Tabell 4: Fordeling av endelsene ved polske adjektiver ........................ 138

Tabell 5: Sterk adjektivbøyning i tysk................................................... 141

Tabell 6: Svak adjektivbøyning i tysk - etter bestemte artikler ................. 141

Tabell 7: Svak adjektivbøyning i tysk - etter ubestemte artikler .............. 141

Tabell 8: Typer adjektivbøyning i norsk, polsk, engelsk og tysk ............ 142

Tabell 9: Informantenes alder............................................................... 151

Tabell 10: Informantenes kjønn.......................................................... 151

Tabell 11: Informantenes utdanning................................................. 152

Tabell 12: Informantenes oppholdstid i Norge ......................................... 152

Tabell 13: Antall kurstimer i norsk informantene har tatt før Språkprøven ............................................................................ 153

Tabell 14: Vurdering av informantenes tekster ved hjelp av CEFR-nivåer ......................................................................... 154

Tabell 15: Informantenes norskbruk.................................................... 154

Tabell 16: Informantenes motivasjon / kursmål ...................................... 155

Tabell 17: Informantenes sysselsetting i Norge...................................... 155

Tabell 18: Informantenes yrke............................................................. 156

Tabell 19: Antall adjektiver som resultat av søket i ASK-korpuset........... 158

Tabell 20: Antall adjektiver etter korreksjonen, totalantall ord og relativt antall adjektiver ift. alle ordene i tekstene.................... 158

Tabell 21: Antall adjektiver etter bøyningstyper ...................................... 160

Tabell 22: Rasjonalet for intragruppe-homogenitet.................................. 169

Tabell 23: Rasjonalet for intergruppe-heterogenitet............................... 171

Tabell 24: Rasjonalet for tverrspråklig performansesamsvar .................. 172

Tabell 25: Typer adjektivbøyning hos de polskspråklige informantene .... 181

Tabell 26: Adjektiver i attributiv og predikativ posisjon brukt av de polskspråklige informantene .................................... 181

Tabell 27: Antall feil i attributiv og predikativ posisjon gjort av de polskspråklige informantene ....................................................... 182

Tabell 28: Typer feil i kongruens gjort av de polskspråklige informantene .................................................................... 182

Tabell 29: Mangel på kongruens hos de polskspråklige informantene...... 183

Tabell 30: Adjektivene som ikke ble markert med endelsen - $t$ av de polskspråklige informantene............................................... 188

Tabell 31: Adjektivene som ikke ble markert med endelsen -e av de polskspråklige informantene............................................... 192

Tabell 32: Feil bruk av kongruens hos de polskspråklige informantene.... 193 
Tabell 33: Adjektivene som ble markert med endelsen -t av de polskspråklige informantene $\mathrm{i}$ kontekster der det ikke var nødvendig.

Tabell 34: Adjektivene som ble markert med endelsen -e av de polskspråklige informantene $\mathrm{i}$ kontekster der det ikke var nødvendig....

Tabell 35: Feil bruk av kongruensendelsene hos de polskspråklige informantene

Tabell 36: Fordeling av CEFR-nivåer blant de polskspråklige norskinnlærerne $(\mathrm{N}=200)$

Tabell 37: Feil i adjektivkongruens etter CEFR-nivå gjort av de polskspråklige informantene

Tabell 38: Korrelasjonen mellom antallet feil i adjektivisk samsvarsbøyning i norsk og CEFR-nivå i S2 norsk hos S1-polskspråklige; resultater fra Mann-Whitney-testen med Bonferroni-korrigering ..... 211

Tabell 39: De polske informantenes alder

Tabell 40: Feil i adjektivkongruens etter aldersgruppe gjort av de polskspråklige informantene

Tabell 41: Feil i adjektivkongruens etter utdanningsnivå gjort av de polskspråklige informantene

Tabell 42: Antall kurstimer i norsk de polskspråklige norskinnlærerne har tatt før Språkprøven $(\mathrm{N}=100)$.

Tabell 43: Feil i adjektivkongruens etter antallet kurstimer de polske informantene har tatt før Språkprøven

Tabell 44: Feil i adjektivkongruens for oppholdstid i Norge

Tabell 45: Ferdigheter i engelsk som S3 hos de polskspråklige informantene

Tabell 46: Feil i adjektivkongruens etter kunnskaper i engelsk som S3 gjort av de polskspråklige informantene ..................................... 224

Tabell 47: Antallet forekomster av adjektivkongruens for $\mathrm{S} 1$.................. 228

Tabell 48: Feil i adjektivkongruens for S1-gruppene ............................. 231

Tabell 49: Feiltyper i kongruens for S1 .............................................. 236

Tabell 50: Adjektiver brukt i samsvarsbøyning i attributiv stilling for $\mathrm{S} 1$

Tabell 51: Adjektiver brukt i samsvarsbøyning i predikativ stilling for $\mathrm{S} 1$

Tabell 52: Feil i adjektivisk samsvarsbøyning i attributiv stilling for $\mathrm{S} 1$

Tabell 53: Feil i adjektivisk samsvarsbøyning i predikativ stilling for S1 ... 253

Tabell 54: Resultater fra pilotundersøkelsen

Tabell 55: Studentenes svar i pilotundersøkelsen 314 


\section{Liste over diagrammer og figurer}

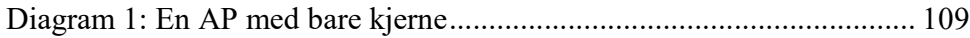

Diagram 2: En AP med to kjerner .............................................................. 109

Diagram 3: En AP med AdvP som premodifikator ..................................... 111

Diagram 4: En AP med AP som premodifikator ....................................... 111

Diagram 5: En AP med PP som premodifikator...................................... 112

Diagram 6: En AP med AdvP som postmodifikator................................... 113

Diagram 7: En AP med VP (infinitivskonstruksjon) som post-

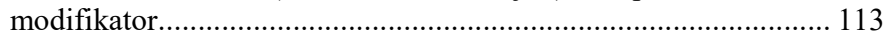

Diagram 8: En AP med PP som postmodifikator ...................................... 114

Diagram 9: En AP med NP som postmodifikator..................................... 114

Diagram 10: En AP med leddsetning som postmodifikator ....................... 115

Diagram 11: Hagens (2008: 115) hierarki for adjektivkategoriene ............ 116

Diagram 12: En modifisert hierarki av adjektivkategoriene....................... 117

Diagram 13: Ulike varianter av feil i 'mangel på kongruens' versus resterende typer feil i kongruens gjort av de polskspråklige informantene

Diagram 14: Ulike varianter av feil i 'feil bruk av kongruens' versus resterende typer feil i kongruens gjort av de polskspråklige informantene

Diagram 15: Korrelasjonen mellom antallet feil i adjektivkongruens og CEFR-nivå i S2-norsk hos S1-polskspråklige informantene.

Diagram 16: Adjektiver brukt i kongruens for S1 ................................... 229

Diagram 17: Feil i adjektivisk samsvarsbøyning i S1 polsk ........................ 232

Diagram 18: Feil i adjektivisk samsvarsbøyning i S1 engelsk ................... 232

Diagram 19: Feil i adjektivisk samsvarsbøyning i S1 tysk ......................... 233

Diagram 20: Adjektiver i kongruens i attributiv stilling for S1 ................. 251

Diagram 21: Adjektiver i kongruens i predikativ stilling for S1 ............... 251

Diagram 22: De S1-polskspråkliges feil i adjektivkongruens som prosent av alle adjektiver i kongruens de produserte $\mathrm{i}$ attributiv og predikativ stilling ………………............................................ 255

Diagram 23: De S1-engelskspråkliges feil i adjektivkongruens som prosent av alle adjektiver $i$ kongruens de produserte $i$ attributiv og predikativ stilling

Diagram 24: De S1-tyskspråkliges feil i adjektivkongruens som prosent av alle adjektiver $\mathrm{i}$ kongruens de produserte $\mathrm{i}$ attributiv og predikativ stilling

Figur 1: En 'computational' modell av S2-tielgense

(hentet fra R. Ellis 2012: 35)

Figur 2: Formering av et mellomspråksregel (hentet fra Færch \& Kasper 1980:66). 
Figur 3: Fordeling av CEFR-nivåer i norsk som S2

blant de polskspråklige norskinnlærerne $(\mathrm{N}=200)$ 208

Figur 4: Relativt antall feil i adjektivisk samsvarsbøyning etter CEFRnivå gjort av de polskspråklige informantene 210

Figur 5: Relativt antall feil i adjektivisk samsvarsbøyning for alder... 215

Figur 6: Relativt antall feil i adjektivisk samsvarsbøyning etter utdanningsnivået gjort av de polskspråklige informantene .... 217

Figur 7: Relativt antall feil i adjektivisk samsvarsbøyning etter antallet kurstimer i norsk de polskspråklige informantene har tatt før Språkprøven

Figur 8: Relativt antall feil i adjektivisk samsvarsbøyning for oppholdstid i Norge 222

Figur 9: Relativt antall feil i adjektivisk samsvarsbøyning etter kunnskaper i engelsk som S3 hos de polskspråklige informantene. 225

Figur 10: Typer adjektivbøyning for S1 ........................................... 227

Figur 11: Relativt antall feil i adjektivisk samsvarsbøyning for $\mathrm{S} 1$.......... 235

Figur 12: Relativt antall feil $i$ attributiv stilling for $\mathrm{S} 1$............................ 257

Figur 13: Relativt antall feil i predikativ stilling for S1......................... 257 


\section{Forord}

Arbeidet med denne avhandlingen har pågått i fire år, og nå vil jeg benytte meg av anledningen til å takke alle som har bidratt til at jeg kom i mål.

Jeg vil først takke min veileder prof. Grzegorz Skommer og min biveileder dr. Paulina Horbowicz for deres gode råd og innspill. Deres tålmodighet, oppmuntring og konstruktive kommentarer har betydd mye for meg, og har sikkert bidratt til at denne avhandlingen har blitt til. Også mine kolleger på Katedra Skandynawistyki må takkes for det faglige utbyttet og den gode atmosfæren de skaper. Spesielt takk til prof. Dominika Skrzypek, dr. Joanna Cymbrykiewicz, dr. Aldona Zańko, dr. Mikołaj Sobkowiak og mgr. Aleksandra Wilkus for all støtte jeg har fått.

Takk også til mine to veiledere i Norge, prof. Kari Tenfjord og prof. Ingvild Nistov, for inspirasjon, faglige diskusjoner og entusiasme. En stor takk fortjener også deltakerne i ASKeladden-prosjektet som var min støtte og inspirasjonskilde under oppholdet ved Universitetet i Bergen, og som hjalp meg med å utvikle og ordne mine ulike ideer. En spesiell takk vil jeg rette mot Anne Golden, Jon Erik Hagen, Scott Jarvis, AnnKristin Helland Gujord, Silje Ragnhildstveit og Marte Nordanger. Jeg vil også takke Victoria Rosén som er lederen i Forskerskolen i lingvistikk og filologi ved UiB, og alle deltakerne $\mathrm{i}$ forskerskolen. Jeg har lært mye både på de tallrike kursene vi har hatt, og på de vanlige lunsjene vi har spist sammen.

Mine lange opphold ved UiB var mulige takket være stipendet Yggdrasil tildelt av Norges forskningsråd fra september 2012 til august 2013, og Semesterstipendet tildelt av Senter for internasjonalisering av utdanning i mai 2015.

Jeg vil i tillegg rette en takk til Espen Iden for norskkonsultasjon, Christiane Sanders for tyskkonsultasjon, Mikołaj Sobkowiak for engelskkonsultasjon, og Hanna Winiszewska 
for polskkonsultasjon. En takk fortjener mine studenter, som har inspirert meg til å utforske tilegnelsen av kongruensbøyning i norsk som andrespråk.

Til slutt vil jeg takke min familie og mine venner for støtte og motivasjon. Takk!

Poznań, september 2015

Marta Janik 


\section{Innledning}

Despite extensive research, agreement remains deeply puzzling. There was time when it was treated mainly as a tool for researching other syntactic phenomena. Yet there has also been a tradition of recognizing it as a challenging problem in its own right. (Corbett 2006: 1)

Kongruens er et utfordrende fenomen ikke bare for (tradisjonelle) lingvister, men også for andrespråksforskere, og særlig innlærere av andrespråk. Som Lyons (1971: 239) påstår, faller kongruens inn under det man vil kalle 'kontekstsensitivitet' ('context-sensitivity'). Kontekstsensitiviteten kan forstås som kunnskap om hvilke elementer i et utsagn som hører sammen, og viser samhørigheten gjennom bøyning. Riktignok kan det antas at kunnskapen om hvilke elementer som hører sammen i et utsagn, er noe alle mennesker står til rådighet med, men kunnskapen om hvilke av disse elementene som viser denne samhørigheten gjennom bøyning, er snarere språkspesifikk. For andrespråksinnlærere betyr det at de må lære seg kontekstsensitiviteten i målspråket for å være i stand til å tilegne seg kongruensbøyning.

$\AA$ tilegne seg denne sensitiviteten er ikke lett arbeid, noe som jeg selv kan bekrefte på grunnlag av mine erfaringer som andrespråksinnloerer og andrespråkslcerer. Det var nettopp mine studenter ved Universitetet som i 2010 inspirerte meg til å undersøke problemet forbundet med tilegnelsen av samsvarsbøyning av norske adjektiver. De gjorde nemlig mange feil i adjektivbøyningen, både på første og tredje året (jeg underviste da bare de to årstrinnene). Dette gjorde meg nysgjerrig på hvorfor de gjorde så mange feil, og det til tross for at adjektivbøyning i norsk ikke er altfor komplisert, iallfall i forhold til noen andre grammatiske trekk i norsk (f.eks. bestemthet, perfektum), og i forhold til adjektivbøyning $i$ andre språk, for eksempel tysk. Studentene gjorde feil både i muntlige og skriftlige utsagn. Flere ganger forklarte jeg samsvarsbøyningsreglene for dem, og flere ganger testet jeg deres kunnskaper i 
ulike prøver. Feilandelen lå da vanligvis på cirka 20-25\%, slik som i pilotundersøkelsen ${ }^{1}$. Den var en del av en annen test andreårsstudentene ${ }^{2}$ tok, og besto av 9 setninger hvor adjektivene ble tatt bort og satt i parentes i ubøyd form. Studentenes oppgave var å bøye adjektivene i samsvar med kontrolløren (kontrollørene var substantiver, pronomener eller kvantoren begge). Det var 21 studenter som tok testen, og andelen feil var $29 \%$ i dette tilfellet.

I doktorgradsprosjektet har jeg bestemt meg for å bruke korpuset $A S K$ og ikke universitetsstudentene som datakilde, og det har jeg gjort av to grunner. For det første kan det gi upålitelige data å teste de samme studentene man underviser, da undervisningen lett kan bli påvirket av forskningsspørsmålene man har stilt, slik at det oppstår en risiko for undervisningseffekt på informantenes performanse. For det andre ville jeg i studien min bruke ASK-korpuset som gir større generaliseringsmuligheter enn en undersøkelse av noen få studenter. Jeg ble kjent med dette verktøyet da jeg arbeidet på min masteroppgave med tittelen En polakk $i$ norsk fortid. Om feil gjort av polskspråklige norskinnloerere $i$ bruk av perfektum og preteritum som jeg leverte i 2010. Jeg var svært imponert over mulighetene et innlærerkorpus gir. En stor innflytelse på at jeg valgte ASK, hadde også deltakelse i forskningsprosjektet ASKeladden hvor ASK var et grunnleggende verktøy i forskningen, og ble brukt i mange ulike prosjekter, for å få større innsikt i og kunnskap om tverrspråklig innflytelse, mellomspråk, og språk generelt.

${ }^{1}$ Oppgaven brukt i pilotundersøkelsen er vedlagt (se s. 262).

${ }^{2}$ Det var i 2011 da jeg underviste første- og andreårsstudenter. 


\subsection{Teoretisk utgangspunkt og formålet med avhandlingen}

Denne avhandlingen er skrevet innen fagfeltet norsk som andrespråk. Pioneren i dette feltet, som har blitt utviklet siden 1997, er Kari Tenfjord, nå professor ved Universitetet i Bergen. Tenfjord har bidratt til utviklingen av feltet blant annet ved å etablere og lede ulike forskningsprosjekter hvorav den mest kjente kanskje er det NFR ${ }^{3}$-støttete prosjektet ASKeladden morsmålstransfer $i$ norsk innlcererspråk - en korpusbasert tilnoerming.

Andrespråksloring er definert av Berggreen og Tenfjord (1999: 15) som studien om det å lære et nytt språk (et andrespråk, eng. second language) etter å ha først tilegnet seg sitt førstespråk - morsmålet. Den viktigste grunnen til at denne fagdisiplinen oppsto på 1960-tallet, var (og er fremdeles) behovet for å forstå prosessene som ligger bak det å lære og det å kunne to eller flere språk ettersom behovet for tospråklighet er stadig blitt større (N. Ellis 1997: 3). Fordi innvandrerantallet i Norge utgjør nå over 800.000 personer ${ }^{4}$, er utviklingen av fagfeltet norsk som andrespråk begrunnet ikke bare med vitenskapelige, men også samfunnsmessige årsaker.

Det teoretiske utgangspunktet til denne avhandlingen er kognitive teorier om andrespråkslæring hvor man går ut fra at det å lære et andrespråk er lik enhver annen læring (Berggreen \& Tenfjord 1999: 291). Andrespråkslæringen skjer hos mennesker i deres hjerne, og ulike mentale prosesser er ansvarlig for den. Ifølge kognitive teorier påstås det at man gjennom andrespråkslæringen utvikler et språklig system, noe man kaller for mellomspråk (eng. interlanguage) som Gass og Selinker beskriver på følgende måte:

The basic assumption in SLA research is that learners create a language system, known as an interlanguage (IL). This concept validates learners' speech, not as a deficit system, that is, a

${ }^{3} \mathrm{NFR}=$ Norges forskningsråd.

${ }^{4}$ Kilde: SSB_3, SSB_4. 
language filled with random errors, but as a system of its own with its own structure. This system is composed of numerous elements, not the least of which are elements from the NL and the TL5. (Gass og Selinker 1994:14)

Det å forske på andrespråkslæring dreier seg derfor om å forske på mellomspråket til en person som tilegner seg et andrespråk. Fordi mellomspråk er mentale systemer, kan de ikke undersøkes direkte, men bare på grunnlag av språkbruken eller performansen («the actual use of language in concrete situations», Chomsky 1965: 4).

Ved å undersøke performansen/mellomspråket kan man altså trekke konklusjoner angående kompetansen («the speakerhearer' knowledge of his language», ibid.) og de mentale prosessene som står bak dens utvikling. Det er ulike fenomener som kan påvirke mellomspråket: psykolingvistiske, rent lingvistiske, sosiale og individuelle ${ }^{6}$ (R. Ellis 2012). Til de psykolingvistiske aspektene av mellomspråket hører blant annet tverrspråklig innflytelse og prosesseringsoperasjoner, til de lingvistiske faktorene som kan ha påvirkning på mellomspråket hører: markerthet, saliens, frekvens, blant de sosiale kan man nevne frekvensen andrespråket er brukt i, og noen av eksemplene på individuelle faktorer er alder, utdanningsnivå og motivasjon (ibid.). Å undersøke mellomspråket betyr altså å undersøke de psykolingvistiske, lingvistiske, sosiale og individuelle prosessene som er knyttet til det.

Formålet med avhandlingen er å gi en større innsikt $\mathrm{i}$ prosessene bak tilegnelsen av norsk som andrespråk hos polskspråklige norskinnlærere. Jeg skal ta hensyn både til de psykolingvistiske, lingvistiske og sosiale (i den bredere betydningen) aspektene til tilegnelsen av adjektivkongruens $i$ norsk som andrespråk hos innlærere med polsk som morsmål. Jeg skal derfor finne ut hvilken rolle morsmålstransferen fra

${ }^{5}$ Forkortelsene betyr: $\mathrm{NL}=$ native language (førstespråk), $\mathrm{TL}=$ target language (målspråk).

${ }^{6}$ I avhandlingen bruker jeg imidlertid begrepet sosiale både i forhold til de rent sosiale faktorene, og til de individuelle. 
polsk spiller i tilegnelsen av norsk samsvarsbøyning av adjektiver, og hvilke andre sosiale faktorer som påvirker den. I tillegg skal jeg undersøke hvordan den lingvistiske konteksten adjektivene befinner seg i, og hvordan bøyningsparadigmet adjektivene hører til, påvirker innlærernes evne til å samsvarsbøye dem korrekt. På dette grunnlaget vil jeg prøve å bestemme et utviklingsmønster adjektivene er tilegnet etter. Jeg er imidlertid klar over at både den typen data jeg har og metoden jeg bruker, ikke gjør det mulig å bestemme utviklingsmønsteret med den sikkerhet som er nødvendig i et vitenskapelig arbeid.

\subsection{Data og metode}

Datamaterialet brukt i denne avhandlingen er hentet utelukkende fra Norsk andrespråkskorpus ASK. ASK er et elektronisk innlærerkorpus som er blitt videreutviklet ved Universitetet i Bergen av forskergruppen ASKeladden, som jeg selv var medlem av. Korpuset inneholder tekster skrevet av morsmålsbrukere av ti ulike språk: albansk, engelsk, nederlandsk, polsk, russisk, serbokroatisk, somali, spansk, tysk, vietnamesisk. Tekstene er autentiske besvarelser (stiler) i to språktester: Språkprøven i norsk for voksne innvandrere og Test $i$ norsk - høyere nivå. Det er 200 tekster skrevet av hver morsmålsgruppe, 100 på hvert av testnivåene. Fordi prosjektet mitt gjelder de polskspråkliges tilegnelse av norsk adjektivkongruens, er det bare deres tekster som er brukt i analysen i denne avhandlingen. Unntaket utgjør transferanalysen hvor jeg sammenligner de polskspråkliges mellomspråk med mellomspråket til de engelsk- og tyskspråklige som kan derfor betraktes som kontrollgrupper i denne studien.

Opprinnelig, da prosjektet ennå var i planleggingsfasen, vurderte jeg muligheten til å utfylle analysen med å bruke også andre datakilder, for eksempel ved å teste polskspråklige norskinnlærere selv. I løpet av analysen oppdaget jeg imidlertid at korpusdataene fra ASK-korpuset ga meg mer enn nok analysemateriale. Av den grunn bestemte jeg meg for å avgrense 
meg til å analysere dataene fra ASK, og samtidig for å utnytte dette materialet i størst mulig grad. Fordi elektroniske korpuser generelt inneholder store datasett, er dataene ofte behandlet statistisk, noe som gir generaliseringsmuligheter (McEnery \& Hardie 2012: 2). Ettersom man i ASK har mulighet til å lese hele tekster skrevet av informantene, kan det i dette tilfellet også gjennomføres kvalitative undersøkelser på dette datasettet, og denne anledningen har jeg benyttet meg av.

Avhengig av forskningsspørsmål anvender jeg tre metoder $i$ analysen: en kvalitativ analyse, en kvantitativ (statistisk) analyse, og en transferanalyse som kombinerer de to andre typene. Ved hjelp av den kvalitative metoden beskriver jeg de polskspråkliges performanse i den norske adjektivkongruensen. Jeg tar for meg både korrektbruken og feilene informantene har gjort. Hovedvekten ligger imidlertid på feilene som jeg har delt opp i tre kategorier: 1) mangel på kongruens (dvs. bruk av ingen endelse når en endelse, enten $-t$ eller $-e$, er nødvendig), 2) feil bruk av kongruens (dvs. bruk av en endelse, enten - $t$ eller - $e$, når ingen endelse er nødvendig), 3) feil kongruensendelse (dvs. enten bruk av - $t$-endelsen når $-e$-endelsen er nødvendig eller omvendt). En slik feilinndeling er mulig ettersom jeg i analysen skiller mellom kontekster for adjektivisk samsvarsbøyning (dvs. adjektivforekomster som trenger enten -t- eller -e-endelse) og null-kontekster for adjektivisk samsvarsbøyning (dvs. adjektivforekomster som ikke trenger noen endelse, f.eks. når adjektiver står predikativt til et maskulint eller feminint substantiv i entall). I den kvalitative delen av analysen prøver jeg å svare på de forskningsspørsmålene som angår den grammatiske konteksten til feilene (Hvilke fraser polskspråklige innlærere bruker adjektiver i?; Hvilke av frasene skaper (ikke) problemer?; Hvorfor skaper noen av frasene problemer?), og egenskapene de feilbøyde adjektivene har (Hvilket paradigme hører de til?).

Den statistiske analysen tjener andre formål. Ved hjelp av statistiske tester prøver jeg å finne korrelasjoner mellom antallet feil i adjektivkongruens de polskspråklige gjør, med seks 
faktorer som i denne sammenhengen kalles for sosiale. De testete faktorene er: generelle norskkunnskaper (målt i CEFRnivåer), alder, utdanning, antall kurstimer i norsk, oppholdstid i Norge, kunnskaper i engelsk som S3. Testene jeg anvender i denne undersøkelsen er: Kruskal-Wallis, Mann-Whitney og Wilcoxon testen. Normaldistribusjon er sjekket ved hjelp av Shapiro-Wilk testen, og i tilfeller når jeg gjentar en test for det samme utvalget, bruker jeg Bonferroni-korrigering.

Metoden som er brukt i transferanalysen, er hentet fra Jarvis og Pavlenko (2008) og Jarvis (2010). Den bygger på fire typer observasjoner for tverrspråklig innflytelse: intragruppehomogenitet, intergruppe-heterogenitet, tverrspråklig performansesamsvar og innenspråklige ulikheter. De to første fenomenene blir i min undersøkelse testet samtidig ved hjelp av to statistiske tester: Kruskal-Wallis og Mann-Whitney testen (som er en post-hoc test). For at de to kravene blir oppfylt, må man vise at variasjoner i oppførselen innen en morsmålsgruppe er mindre enn variasjoner mellom denne morsmålsgruppen og andre morsmålsgrupper som er forskjellige med hensyn til det trekket man undersøker (Jarvis og Pavlenko 2008: 46). Tverrspråklig performansesamsvar er en type observasjon av kvalitativ karakter. Her sammenligner man innlærernes utsagn i et andrespråk med deres utsagn i morsmålet ${ }^{7}$ for å sjekke om det finnes en korrespondanse i bruken av det gitte trekket i S1 og S2 (Jarvis og Pavlenko 2008: 47). Innenspråklige ulikheter kombinerer i sin tur kvalitative og kvantitative metoder, og de består av å undersøke om innlærere viser forskjeller i bruken av strukturer av et gitt språklig S2-fenomen hvorav en del av strukturene er kongruent med S1, og en del ikke (Jarvis 2000: 175-176). Metodologisk rigorisme krever å finne bevis på alle de fire typene observasjoner, men i noen tilfeller kan en type erstattes av andre (Jarvis 2010: 182).

${ }^{7}$ Ettersom ASK ikke inneholder informantenes tekster i deres morsmål, sammenligner jeg deres utsagn i S2 med deres hypotetiske utsagn i S1. Jeg oversatte selv deres ukorrekte (når det gjelder adjektivisk samsvarsbøyning) setninger skrevet på S2 norsk til deres morsmål: polsk, engelsk og tysk. 
Jeg har bestemt meg for først og fremst å undersøke feilforekomstene i adjektivkongruens (med et lite unntak i den kvalitative delen av analysen hvor jeg også ser på korrektbruken). En slik avgjørelse er motivert med at jeg for det første ser på feil- og korrektbruk som to sider av det samme fenomenet. Hvert adjektiv er enten korrekt eller ukorrekt bøyd (det finnes ingen mellomnivåer her) slik at antall feilbøyde adjektiver og antall korrekt bøyde adjektiver utgjør $100 \%$ av alle adjektivene brukt av informantene. Feilanalysen er dessuten mer rimelig å gjennomføres ettersom det er betydelig færre feil i korpuset enn korrekt bruk av adjektivisk samsvarsbøyning (hos de polskspråklige norskinnlærerne utgjør feilkongruensbøyde adjektiver 7,4\%). Jeg skal trass i det ha Tenfjords ord i bakhode under analysen, og ikke undervurdere mellomspråk som selvstendige systemer:

Mellomspråk, som gjerne blir karakterisert i negative vendinger som avvikende, som mangelfulle, som rudimentære osv., er som studieobjekt en rik og uuttømmelig kilde, ikke bare til innsikt i mellomspråk, men til innsikt i og kunnskap om språk generelt. (Tenfjord 1997: 243)

\subsection{Avhandlingens rekkevidde}

Fordi adjektiv er et ganske uklart begrep som kan defineres på ulike måter (jf. f.eks. Hagen 1998, Kulbrandstad 2005, NRG 1997 og Rønhovd 1993), er jeg tvunget til å begrense det til et operasjonsbegrep, noe jeg gjør i kapittel 3. I avhandlingen analyserer jeg ordene jeg betegner som prototypiske adjektiver, det vil si ord som denoterer enkelte egenskaper, som kan brukes både $\mathrm{i}$ attributiv og predikativ stilling $\mathrm{i}$ setningen, og som kan grad- og samsvarsbøyes. Verken substantiver eller adverb, eller partisipper, possessiver og ordenstall (med unntak av første) er tatt med i analysen.

To andre begrensninger har sine grunner i avhandlingens tema: Adjektivbøyning i norsk - kongruenstilegnelse hos polskspråklige norskinnlarere. For det første fokuseres det her bare 
på kongruensbøyning av adjektiver, og ikke på andre typer bøyning, det vil si adverbial- og gradbøyning (gradbøyde adjektiver som kan kongruensbøyes er inkludert i analysen, mens adjektiver i komparativ, som ikke kan kongruensbøyes, er blitt ekskludert). En slik begrensning er gjort av økonomiske årsaker - det er rett og slett ikke plass i avhandlingen til å undersøke alle de tre bøyningstypene, og derfor har jeg konsentrert meg bare om samsvarsbøyningen. For det andre er analysen begrenset til norskinnlærere med polsk som morsmål. Det er imidlertid et unntak her - i transferanalysen tester jeg også to andre morsmålsgrupper: den engelske og den tyske. $\AA$ undersøke andre morsmålsgrupper er forlangt av metoden jeg bruker (framstilt i Jarvis og Pavlenko 2008 og Jarvis 2010) hvor man må sammenligne performansen til en morsmålsgruppe med en annen (eller flere andre) morsmålsgruppe(r). Jeg vil derfor også stille hypoteser som angår den engelske og den tyske morsmålsgruppen.

\subsection{Avhandlingens oppbygging}

Avhandlingen er delt opp i seks kapitler som tjener ulike formål. Hvert av kapitlene består av underkapitler som i flere tilfeller er videre delt i seksjoner, underseksjoner, og noen få ganger også avsnitt. Strukturen i avhandlingen har altså fem nivåer.

Det første kapittelet - Innledning danner bakgrunnen for hele oppgaven. I det andre kapittelet presenterer jeg den teoretiske tilnærmingen som skaper rammer for analysen. Her omtaler jeg fagdisiplinen andrespråkslæring med hovedvekt på norsk som andrespråk. Videre legger jeg fram kognitive teorier om andrespråkslæring og drøfter følgende fenomener: mellomspråk, transfer, prosessering, utviklingsmønstre i mellomspråk og språklæringsprosessen. Det tredje underkapittelet tar for seg såkalte sosiale faktorer som muligens har påvirkning på tilegnelsen av norsk samsvarsbøyning av adjektiver. Her presenterer jeg forskningsresultater fra andre studier om disse 
faktorenes innflytelse på andrespråkstilegnelsen. Videre i Kapittel 2 viser jeg resultater fra studier om tilegnelsen av kongruens, adjektiver og adjektivets bøyningskategorier: genus og bestemthet. Kapittelet slutter med en presentasjon av hypoteser og forskningsspørsmål som vil bli testet og svart på gjennom analysen.

Kapittel 3 er en støtte til analysen. Her forklarer jeg hva jeg betrakter som adjektiver i denne oppgaven slik at jeg setter en skarp grense mellom denne ordklassen og de andre ordklassene som i andre sammenhenger også kan klassifiseres som adjektiver. I dette kapittelet definerer jeg i tillegg kongruensbegrepet og andre begreper som er forbundet med det. Det tredje kapittelet inneholder dessuten et omfangsrikt underkapittel som drøfter egenskaper ved adjektiver, og som gir en omfattende presentasjon av det norske adjektivets bøyningsparadigmer, og bruken av disse paradigmene.

I det fjerde kapittelet presenterer jeg datamaterialet som er brukt i analysen, og gir grundige (så vidt der er mulig) opplysninger om informantene. I den andre delen av dette kapittelet beskriver jeg hvordan dataene mine er behandlet $\mathrm{i}$ analysen, og hvilke metoder jeg anvender i analysen.

Kapittel fem inneholder dataanalysen, og består av tre underkapitler. Først beskriver jeg de polskspråklige informantenes performanse i norsk kongruensbøyning av adjektiver, så undersøker jeg hvilke sosiale faktorer som påvirker deres performanse, og til slutt sammenligner jeg de polskspråkliges performanse med performansen til de engelsk- og tyskspråklige norskinnlærerne i en transferanalyse.

Det siste kapittelet inneholder konklusjoner, og består av tre underkapitler: i det første diskuterer jeg studieresultater, i det andre drøfter jeg resultatene i lyset av didaktiske formål, og til sist gir jeg forslag om videre forskning. 


\section{Teoretisk tilnærming}

I dette kapittelet vil jeg skissere den teoretiske tilnærmingen som danner bakgrunnen for analysen i denne avhandlingen. Det første underkapittelet tar for seg begrepet andrespråkslcering og gir en kort oversikt over fagdisiplinen norsk som andrespråk. Den sentrale plassen i denne presentasjonen, som utgjør underkapittel to, har kognitive teorier om andrespråkslæring, og det legges spesielt fokus på tverrspråklig innflytelse og prosessering her. I tillegg til det blir mellomspråkbegrepet forklart her, og et overblikk gitt over utviklingsmønstre i mellomspråket, og språklæringsprosessen. Det tredje underkapittelet behandler tilegnelse av kongruens, med hovedvekt på tilegnelse av kongruens i skandinaviske språk. Også tilegnelse av to kategorier som er sterkt forbundet med kongruens, blir drøftet her: genus- og bestemthetskategorien. Det fjerde underkapittelet tar for seg sosiale faktorer som kan påvirke tilegnelse av et andrespråk. Betegnelsen sosiale blir her brukt i generell betydning og dekker flere områder slik at følgende faktorer blir omhandlet her: generelle S2-kunnskaper, alder, utdanning, antall kurstimer, oppholdstid i S2-landet, daglig bruk av S2 samt S3-kunnskaper. Hvert av disse underkapitlene slutter med en oppsummering. Til slutt blir det presentert hypoteser og forskningsspørsmål som er basert på den teoretiske tilnærmingen som er framstilt her, og som vil bli testet videre $\mathrm{i}$ avhandlingen.

\subsection{Andrespråkslæring}

Andrespråksloering (fork. ASL, eng. Second language acquisition - SLA) er definert som studien om det å lære et nytt språk etter å ha først tilegnet seg sitt førstespråk - morsmålet (Berggreen \& Tenfjord 1999: 15). Ortega definerer ASL som:

The scholarly field of inquiry that investigates the human capacity to learn languages other than the first, during late childhood, 
adolescence or adulthood, and once the first language or languages have been acquired. (Ortega 2013: 1-2)

Denne relativt nye fagdisiplinen har vært i stadig utvikling siden slutten av 1960-tallet (ibid.) da den oppsto som svar for stadig større behov for tospråklighet og behov for å forstå prosessene som ligger bak det å lære og det å kunne to eller flere språk (N. Ellis 1997: 3). Behovet for å være tospråklig skyldes først og fremst globaliseringen, stor folkemigrasjon, internasjonal handel, kulturkontakter, utenlandsreiser (Sandøy \& Tenfjord 2006: 7), men bilingvalisme har lenge vært til stede i flere verdensdeler hvor det er vanlig å snakke to eller flere språk (Doughty \& Long 2003b: 4).

Nøkkelbegrepet i ASL er andrespråk (fork. S2, eng. second language - L2) som kan defineres som ethvert språk som blir lært etter morsmålet (Berggreen \& Tenfjord 1999: 16). I så fall kan S2 være både det andre, tredje, fjerde osv. tilegnete språket (ibid.). Morsmålet blir i andrespråkslæringsterminologien omtalt som førstespråket (fork. S1, eng. first language - L1). Skillet mellom S2 og S1 er ikke sjelden vanskelig å sette, men det er vanlig å trekke grensen mellom S2 og S1 ved trefireårsalderen (Ortega 2013: 5). Det er også mulig å ha flere morsmål, for eksempel når et barns foreldre snakker forskjellige språk, kan barnet tilegne seg to førstespråk samtidig (Engen \& Kulbrandstad 2004: 182).

Ofte skjelnes det dessuten mellom andrespråk og fremmedspråk. Andrespråket defineres da som et språk tilegnet gjennom naturlig kommunikasjon, og fremmedspråk - som et språk lært gjennom formell undervisning (Berggreen \& Tenfjord 1999: 16). I slike sammenhenger skilles det mellom uformell tilegnelse (eng. acquisition) og formell loering (eng. learning) (Engen \& Kulbrandstad 2004: 151). Det er imidlertid vanlig å bruke begrepet 'andrespråk' i bredere betydning som dekker begge definisjonene. Med det samme gjør man ingen forskjell på læringskonteksten, noe som er nyttig særlig på grunn av at mange innloerere (dvs. personer som lærer / tilegner seg et andre- / fremmedspråk) ofte kombinerer flere 
læringsmåter, for eksempel utfylles undervisningen i klasserommet med opphold i det landet språket er snakket i. I slike tilfeller er det umulig å snakke entydig om enten andre- eller fremmedspråklæring.

\subsubsection{Norsk som andrespråk}

I det siste har Norge blitt et mer og mer åpent land med stadig større innvandring. Tidligere var det i stor grad asylsøkere fra Østen som kom til landet, men i de siste årene har det kommet hit også mange (ofte høykvalifiserte) arbeidere fra Europa ${ }^{8}$. Både globaliseringen og innvandringen har fort til at norsk brukes av mennesker som ikke har det språket som sitt morsmål. I 2006 var det cirka 300.000 mennesker som snakket «innvandrernorsk» (Sandøy \& Tenfjord 2006: 12), og nå er tallet sikkert større siden innvandrertallet har økt over to ganger fra 2003 til 2015 (fra 332.793 personer i 2003 til 804.964 personer i 2015) ${ }^{9}$. Når det gjelder migrasjon fra Polen, har den øt fra 6.797 bosatte innvandrere i 2004 til mer enn 80.000 i 2014 (Friberg \& Golden 2014: 14), og den er omtalt som «den største migrasjonsbølgen til Norge noensinne» (ibid.). På grunn av innvandringen til Norge har det oppstått behov for å undervise i norsk, og med det samme for å skape kunnskap om hvordan det skal undervises i norsk som andrespråk og hvordan norsk som andrespråk tilegnes. Den første forskeren som har tatt seg av emnet norsk som andrespråk er Kari Tenfjord, nå professor ved Universitetet i Bergen (Johansen mfl. 2010: 5). I sin doktoravhandling fra 1997 beskrev hun i sin longitudinelle studie av tilegnelse av norsk av fire vietnamesiske informanter (Tenfjord 1997). Transfer er der sagt å være en av faktorene som påvirker innlærernes performanse $i$ bruk av norske fortidstempora. Til nå har det kommet ut fire ytterligere

${ }^{8}$ Kilde: SSB_2; jeg har sett bort fra innvandring av svensker, som har lenge vært en av de største innvandrergruppene i Norge (for 1.01.2015 utgjør innvandrere fra Sverige den tredje største innvandrergruppen i Norge, kilde: SSB 1)

${ }^{9}$ Kilde: SSB_3, SSB_4. 
doktorgradsavhandlinger som behandler transfer i norsk som andrespråk: Kløve (1997), Nistov (2001), Szymańska (2010) og Helland Gujord (2013). Påvirkning av førstespråket på andrespråkstilegnelsen er omtalt som et av de viktigste problemene innen forskningen om innlærerspråk, som også utgjør én av de tre utviklingslinjene innen norsk ASL ved siden av forskningen om språk- og kulturkontakt og didaktisk forskning (Golden, Kulbrandstad \& Tenfjord 2007: 12, Helland Gujord 2013: 10). Som Helland Gujord (2013: 10) oppgir, er de fleste transferstudiene av norsk mellomspråk masteroppgaver. Selv om antallet oppgaver og artikler konstant øker, er det fremdeles et bredt spekter av temaer der det er behov for å forskes i. Store forskningsprosjekter som for eksempel ASKeladden (www.uib.no/fg/askeladden) og MultiLing (www.hf.uio.no/multiling/) hjelper til med å utdype kunnskapen om norsk som andrespråk.

\subsection{Kognitive teorier om andrespråkslæring}

Kognitiv vitenskap (cognitive science) er en tverrfaglig disiplin som begynte å utvikle seg sent på 1950- og tidlig på 1960-tallet (Doughty \& Long 2003a: 867), og som legger fokus på menneskets sinn. Ettersom sinnet er en så sammensatt mekanisme, kan disiplinen utforskes fra flere vinkler: den lingvistiske, psykologiske, informatiske, nevrofysiologiske, filosofiske og antropologiske. Tverrfaglighet gjør det mulig for kognitiv vitenskap å forske på blant annet intelligens og resonnement hos mennesker, dyr og maskiner, ulikheter $\mathrm{i}$ kognisjon hos individer og i grupper, lokalisering av mentale funksjoner i hjernen, biologiske begrensninger i språktilegnelsen, måter språket er prosessert, tilegnet, oppbevart, fått tilgang til og brukt på, relasjon mellom innfødt og tilegnet kunnskap og flere andre (ibid.).

Det viktigste utgangspunktet i kognitive teorier om andrespråkslæring (det mangler kun én homogen kognitiv teori om andrespråkslæring) er at språklæring er lik enhver annen 
læring (Berggreen \& Tenfjord 1999: 291). Konsekvenser av en slik påstand er at de samme kognitive prosessene står bak både språklæringen og for eksempel bilkjøring. Som en logisk slutning finnes det, ifølge kognitivistene, ikke noen universell, mental grammatikk (UG) som mennesker er utstyrt med fra fødselen av, noe som generativister påstår (ibid.: 311). Også selve språkfenomenet er betraktet av kognitivister annerledes enn av andre språkforskere:

The most important way in which cognitive linguistics differs from other approaches to the study of language, then, is that language is assumed to reflect certain fundamental properties and design features of the human mind (Evans \& Green 2011: 5).

Ettersom det nå til dags er umulig (og sannsynligvis vil det aldri være mulig) å undersøke menneskets sinn direkte, er ASLforskere nødt til å undersøke det indirekte, det vil se på grunnlag av språkbruken eller performansen («the actual use of language in concrete situations», Chomsky 1965: 4). Man sier derfor at man kan si noe om kompetansen («the speaker-hearer' knowledge of his language», ibid.) ved hjelp av undersøkelsen av performansen, noe Ortega uttaler slik:

This is because inferences about mental processes can only be made by inspecting what is observable during processing while performing tasks, rather than by inspecting external behaviour in response to stimuli, as behaviourists used to do. (Ortega 2013: 82)

Kognitive ASL-teorier understreker spesielt to fenomener: hypotesedannelse og feedback, og ser med det samme på innlæreren som en aktiv konstruktør av grammatikken (Berggreen \& Tenfjord 1999: 294). 


\subsubsection{Mellomspråk}

Mellomspråk (eng. interlanguage) er et sentralt begrep i ASL, og det var først omtalt av Selinker i 1972 som «innlærernes systematiske viten om språk nummer to» (Berggreen \& Tenfjord 1999: 18). Men allerede i 1967 refererte Corder til det samme fenomenet ved å bruke termen transitional competence som han definerte som «[the learner of a second language's] underlying knowledge of the language to date» (Corder 1967: 166). Denne interne grammatikken konstruert av en innlærer viser noen typiske trekk. Berggreen og Tenfjord (1999: 29-30) nevner fem slike generelle trekk ved mellomspråk: enkelhet, ustabilitet, variasjon, tverrspråklig innflytelse (transfer) og forutsigbare utviklingssteg (utviklingsmønstre). De tre første trekkene blir kort omtalt i de neste avsnittene i denne seksjonen, mens de to siste blir behandlet mer omfattende i separate seksjoner.

Som Berggreen og Tenfjord (1999: 34) påstår, «Ser mellomspråksstrukturene ut til å være forenklete utgaver av de korresponderende målspråksstrukturene». Forenklingene forekommer i alle språklige nivåer: det fonologiske, morfologiske, syntaktiske, leksikalske og pragmatiske. Derfor sies det at mellomspråk er enkle språk.

Ustabilitet i mellomspråk er forbundet med utviklingen som skjer gjennom stadig rekonstruering av det språklige systemet. I tilegnelsesprosessen utvikler mellomspråket seg i retningen målspråket, og begynner å ligne mer og mer på det. Tilegnelsen beror på å inkorporere ny kunnskap i det allerede eksisterende språklige systemet som finnes i innlærerens sinn slik at det oppstår et nytt system - et nytt mellomspråk (Gass \& Selinker 2008: 230). Hvordan tilegnelsesprosessen pågår, er bredere omtalt i seksjonen om språklæringsprosessen.

Å si at mellomspråk er variable språk betyr at «At any given stage of development, learners sometimes employ one form, and sometimes another» (Ellis 2012: 25). Det er imidlertid gode grunner for å hevde at også disse variasjonene er 
systematiske, slik som mellomspråk er. Bruken av flere ulike former der det i målspråket brukes én, kan ofte forklares gjennom den spesifikke (enten lingvistiske, situasjonelle, eller psykolingvistiske) konteksten utsagnet er produsert i (ibid.: 26-27).

\subsubsection{Transfer}

Transfer eller tverrspråklig innflytelse (eng. crosslinguistic influence, fork. CLI) er definert av Jarvis og Pavlenko (2008: 1) som «the influence of a person's knowledge of one language in that person's knowledge or use of another language».

Transferbegrepet har imidlertid en over 50 -årshistorie bak seg, og det var brukt av Lado (1957: 59) som en betegnelse for en læringsmekanisme som er en naturlig og forutsigbar følge av kontrastiv analyse (eng. contastive analysis, fork. $C A$ ). Lado (1957: 2) påstår at: «Those elements that are similar to this native language will be simple for him [= innlæreren], and those elements that are different will be difficult». Lado utvikler denne påstanden på følgende måte:

Individuals tend to transfer the forms and meanings, and the distribution of forms and meanings of their native language and culture to the foreign language and culture--both productively when attempting to speak the language and to act in the culture, and receptively when attempting to grasp and understand the language and the culture as practiced by natives. (ibid.)

Problemet med kontrastiv analyse er at det ikke nødvendigvis er ulikheter mellom kilde- og målspråket som skaper innlærerne vansker, noe som Corder (1967: 162) uttrykte i sin artikkel The Significance of Learners' Errors, med hvilken han introduserte en ny retning i ASL - feilanalyse (eng. error analysis, fork. EA). For det første skilte han mellom feil (errors) og glipp (mistakes): 
It will be useful therefore hereafter to refer to errors of performance as mistakes, reserving the term error to refer to the systematic errors of the learner from which we are able to reconstruct his knowledge of the language to date, i.e. his transitional competence. (Corder 1967: 167)

Transferfeil er imidlertid bare én av de tre hovedtypene feil en andrespråksinnlærer kan gjøre, ved siden av intralingvale feil og 'unike' feil (Berggreen \& Tenfjord 1999: 52). EA har i tillegg en svakhet i forhold til CA. Nemlig den at den kun fokuserer på feil (negativ transfer), og ikke tar korrekt bruk av språket (positiv transfer) i betraktning.

Det er dessuten et annet problem ved kontrastiv analyse som Stockwell, Bowen og Martin (1965a, 1965b, referert i Gass \& Selinker 2008: 100) påpeker, og som beror på at kontrastiv analyse bare nevner to typer kontraster som kan oppstå som et resultat av en sammenligning av to språk, nemlig fravoer av en kategori (absent category) og korrespondanse mellom kategoriene (correspondence), mens det i virkeligheten kan skilles ut fem typer kontraster. Alle de fem kontrasttypene kan ordnes i et vanskehierarki ved andrespråklæringen. Vanskehierarkiet går fra vansketypene som skaper størst problemer med tilegnelsen, til de som skaper minst problemer. Tabell 1 viser hierarkiet som er basert på Stockwell, Bowen og Martins (1965a, 1965b), referert i Berggreen og Tenfjord (1999: 203) og Gass og Selinker (2008: 101), men eksemplene er mine og viser situasjon der polsk er S1, og S2 er norsk. De originale eksemplene gjaldt S1 engelsk, og S2 spansk og italiensk. 


\begin{tabular}{|c|c|c|}
\hline Vansketype & \multicolumn{2}{|c|}{ Eksempler med S1 polsk - S2 norsk } \\
\hline \multirow{2}{*}{$\begin{array}{l}\text { splittelse } \\
\text { (differentiation) }\end{array}$} & \multirow{2}{*}{$\begin{array}{l}\text { czas przeszly } \\
\text { (preteritum) }\end{array}$} & preteritum \\
\hline & & presens perfektum \\
\hline $\begin{array}{l}\text { nyhet }=\langle\text { «nullkontrast» } \\
\text { (new category) }\end{array}$ & $\varnothing$ & bestemthet \\
\hline $\begin{array}{l}\text { fravær } \\
\text { (absent category) }\end{array}$ & kasus ved subst. & $\varnothing$ \\
\hline \multirow{2}{*}{$\begin{array}{l}\text { sammenfall } \\
\text { (coalescing) }\end{array}$} & levende maskulinum & \multirow{2}{*}{ maskulinum } \\
\hline & ikke-levende mask. & \\
\hline $\begin{array}{l}\text { korrespondanse } \\
\text { (correspondence) }\end{array}$ & adjektivbøyning & adjektivbøyning \\
\hline
\end{tabular}

Tabell 1: Et vanskehierarki av kontrastene som oppstår som et resultat av en kontrastiv analyse av to språk (basert på Stockwell, Bowen og Martins (1965a, 1965b) med mine eksempler)

Berggreen og Tenfjord (1999: 203) regner med at det kan forekomme tverrspråklig innflytelse fra S1 til S2 ved alle vansketypene. Deres standpunkt er likevel ikke en selvfølge ettersom transfer ofte defineres nettopp på basis av dikotomien likhetene-ulikhetene mellom to språk som fører til en ny dikotomi: læringsletthet versus læringsvansker, slik det er hos Lado (1957:2), sitert ovenfor. Generelt sett betrakter behavioristisk læringsteori (som Lado skriver seg inn i) språktilegnelse som vanedannelse (Gass \& Selinker 2008: 95) der morsmålspåvirkning sees på som interferens (interference). Weinreich (1953) betrakter interferens som en faktor som hindrer vanedannelse i det nye språket, det vil si at det virker negativt på andrespråkstilegnelse, og han definerer begrepet på følgende måte:

Those instances of deviation from the norms of either language which occur in the speech of bilinguals as a result of their familiarity with more than one language, i.e. as a result of languages in contact. (Weinreich 1953: 1) 
I nyere transferforskning betraktes ofte tverrspråklig innflytelse som et resultat av likhetene og ulikhetene mellom to språk, men dikotomiene nevnt ovenfor er opphevet, og det er ingen direkte transmisjon mellom likhetene-ulikhetene og læringsletthetene og -vanskene. En av de mest brukte definisjone av transfer nå er Odlins (1989) definisjon:

Transfer is the influence resulting from similarities and differences between the target language and any other language that has been previously (and perhaps imperfectly) acquired. (Odlin 1989: 27)

Her legger Odlin (ibid.) merke til en sak som ikke har blitt nevnt tidligere: tverrspråklig innflytelse trenger ikke nødvendigvis stamme fra morsmålet og påvirke andrespråket, men den kan fungere i alle mulige retninger. Avhengig av hva som tas som kilde- og målspråket, er det snakk om tre typer transfer: transfer fra et S1 til et S2 - fremovertransfer (forward transfer), transfer fra et S2 til et S1 - tilbaketransfer (reverse transfer), og fra et S2 til et S3 (eller S4 osv.) og omvendt - sidetransfer (lateraltrasfer) (Jarvis \& Pavlenko 2008: 12).

Odlin (1989: 36) poengterer dessuten at transfer kan gi forskjellige typer utslag i mellomspråk. Han nevner:

1. Positiv transfer (positive transfer)

2. Negativ transfer (negative transfer)

a) Underproduksjon - unngåing (underproduction)

b) Overproduksjon - favorisering (overproduction)

c) Produksjonsfeil (production errors)

d) Mistolkning (misinterpretation)

3. Endret tilegnelsestempo (differing lengths of acquisition)

Positiv transfer er definert som korrekt bruk av kildespråkets struktur i målspråket, og negativ transfer som ukorrekt bruk av kildespråkets struktur i målspråket (ibid.). Overproduksjon er $\mathrm{i}$ sin tur betraktet som en konsekvens av underproduksjon, og beror på å produsere for mye av en bestemt 
type struktur i forhold til målspråksnormen. Når det gjelder feil, nevner Odlin (1989: 37) tre typer:

1. substitutions - a use of native language forms in the target language;

2. caiques - errors that reflect very closely a native language structure;

3. alterations of structures.

Mistolkning er forstått som ukorrekt forståelse av målspråkets meldinger, og endret tilegnelsestempo kaller Odlin «cumulative effects of cross-linguistic similarities and differences on the acquisition process» (ibid.: 38). Berggreen og Tenfjord (1999: 212-213) poengterer i tillegg at tverrspråklig innflytelse også kan endre selve læringsløypen, det vil si at «enkelte innlærere kan hoppe over utviklingstrinn eller begynne høyere oppe på 'stigen'», noe som selvfølgelig har påvirkning på læringstempoet.

En viktig observasjon gjorde Jarvis og Odlin (2000: 539) om at tverrspråklig innflytelse ikke bare gjelder innlærernes produksjon, men også forståelse (comprehension) selv om både lytte- og leseforståelse sjelden er omtalt. Ortega understreker i sin tur at:

Crosslinguistic influences go well beyond form-form or formfunction correspondences, and that L1 knowledge across all layers of language can influence L2 solutions at the levels of form, meaning and function. (Ortega 2013: 36-47)

Odlin (2003: 437) legger også merke til at språklig transfer påvirker alle lingvistiske subdomener: pragmatikk, retorikk, semantikk, syntaks, morfologi, fonologi, fonetikk og ortografi. Det er en viktig påstand som ikke alle har vært enige om. Blant annet Dulay, Burt og Krashen (1982: 102) hevder at grammatiske (dvs. morfologiske og syntaktiske) transferfeil er relativt sjeldne, noe Jarvis og Odlin (2000: 553) finner motargumenter mot med å gi bevis på 'transferability of bound morphology' . 
Et annet spørsmål gjelder årsaken til hvorfor innlæreren tyr til tverrspråklig innflytelse, og hvordan hun bestemmer hvilke strukturer som kan 'lånes' fra et språk hun kan til det språket hun lærer. Ifølge Odlin tyder mye på at:

Cross-linguistic influence depends on interlingual identifications, that is, the judgments that something in the native language and something in the target language are similar (Odlin 2003: 454).

De mellomspråklige identifikasjonene og vurderingene Odlin skriver om, kan både være bevisste og ubevisste (Ortega 2013: 33-34), og de avhenger av flere faktorer: innlærerens naturlige talent for å lære språk, personlighet, språkkunnskaper, literacy (mestring av skriftspråket), lingvistisk bevissthet, alder og den sosiale konteksten hun befinner seg i (Odlin 1989). Likevel baserer transferabilitetsbegrepet (eng. transferability) seg på tilnærmingen til Kellerman (1979) om psykotypologiske og transferable begrensninger, og på Andersen (1983) om transfer to somewhere principle (Jarvis \& Pavlenko 2008: 174, Kellerman 1995). Kellermans studie gir bevis på at innlærerne overfører trekk fra et språk til et annet når de for det første vurderer kilde- og målspråket som like, og for det andre - når de ikke betrakter kildespråkets trekk som språkspesifikke, eller med andre ord - de overfører de trekkene som de oppfatter som prototypiske. Andersens (1983) transfer to somewhere principle fokuserer i sin tur på innlærernes allerede eksisterende språkferdigheter i målspråket. Prinsippet lyder slik:

A grammatical form or structure will occur consistently and to a significant extent in interlanguage as a result of transfer if and only if there already exists within the L2 input the potential for (mis-)generalization from the input to produce the same form or structure. (Andersen 1983: 178)

Ifølge Andersen (1983) må innlæreren være klar (dvs. at hun må ha tilstrekkelig kunnskap om målspråket) til å overføre trekk fra et språk til et annet. Kellermans (1979) begrensninger 
og transfer to somewhere principle ser ut til å utfylle hverandre godt. Hos Ortega (2013: 33-34) finner man en oppsummering av diskusjonen om hva som påvirker innlærernes vurderinger om tverrspråklige likheter. Hun nevner tre hovedfaktorer:

1. The nature of the specific L2 phenomenon and the universal forces that shape its natural development;

2. Learners' perceived distance between the L1 and the L2 and their intuitions of what is transferable or not;

3. Learners' relative proficiency level.

Det er verdt å legge merke til at objektivitet finnes utelukkende i det første punktet der det er snakk om arten til et gitt trekk i S2. Det to resterende punktene gjelder innlæreren hennes persepsjon, intuisjon og språkkunnskaper. Det er særlig viktig å legge merke til at det er innlæreren selv som må observere likheter og forskjeller mellom språkene selv om det $\mathrm{i}$ mange tilfeller kan gjøres på feil grunnlag, og har ikke mye til felles med virkelig eksisterende kontraster:

While it may be clear to the linguistic analyst which of the diacritic features of the L1 apply to the L2, and which syntactic patterns are shared between the languages, there is no obvious a priori way for the learner to know this. (Pienemann mfl. 2005a: 95)

Det kan altså sies at tverrspråklig innflytelse er et subjektivt og psykolingvistisk fenomen, noe som følgelig påvirker måten den kan undersøkes på.

Problemet med å identifisere transferforekomster i innlærerutsagn er også forbundet med at det oftest samvirker flere andrespråklæringsprosesser der. Selinker (1992: 263) hevder at: «In every instance of the multiple effects principle, language transfer will be involved». Uavhengig av hvorvidt transfer er «a you-know-it-when-you-see-it phenomenon» (Jarvis 2000: 246), eller «so subtle or so obscured by other factors that it cannot be detected simply by looking at the data, no matter how carefully» (Jarvis \& Pavlenko 2008: 27), trenges 
det et koherent rammeverk til å isolere, identifisere og måle transferforekomster. I sin artikkel fra 2000 foreslår Jarvis et slikt rammeverk som også er bredt omtalt i boken Crosslinguistic influence in language and cogniotion av Jarvis og Pavlenko fra 2008. I 2010 supplerte Jarvis rammeverket med å tilføye en type evidens av transfer til - den fjerde. Hele metodologien foreslătt av Jarvis blir omtalt i Metode-kapittelet i denne avhandlingen.

\subsubsection{Prosessering}

En av de viktigste begrensningene tverrspråklig innflytelse kan ha, er kanskje prosesseringsmuligheter. Pienemann, Di Biase, Kawaguchi og Håkonsson (2005b) har testet hypotesen om at transfer fra S1 blir begrenset av en gitt strukturs prosesseringsmuligheter, og de har kommet til følgende konklusjon:

The key predictive factor is always processability. In other words, processability acts as a constraint on L2 transfer and may override typological distance. In addition to this constraining effect, processability also has a facilitating effect that sets in (given structural L1-L2 overlap) once the L2 has developed to the point at which the L1 structure is processable. (Pienemann mfl. 2005b: 147)

Transfer er altså sterkt forbundet med den gitte strukturens prosesseringsmuligheter som danner visse utviklingsmønstre. I denne seksjonen tar jeg for meg prosesseringsbegrepet, mens utviklingsmønstre er behandlet i seksjonen nedenfor.

Prosessering er en prosess som er forbundet med utviklingen av mellomspråket. Dette begrepet er psykolingvistiske kognitive ASL-teorier i stor grad opptatt av, og det stammer originalt fra psykologifeltet (Ortega 2013: 82). For å forklare begrepet sammenligner man menneskets sinn med en prosessor:

In a nutshell, the human mind is viewed as a symbolic processor that constantly engages in mental processes. These mental processes operate on mental representations and intervene between 
input (whatever data get into the symbolic processor, the mind) and output (whatever the results of performance are). (Ortega 2013: 83)

Det skilles mellom to typer prosessering: kontrollert og automatisk. Kontrollert prosessering finner sted når man må konsentrere seg på handlingen man utfører, mens automatisk prosessering skjer uten å sette fokus på den. Segalowitz forklarer forskjellen på følgende måte:

As one's skill level in a domain increases, the amount of attention and effort required to perform generally appears to decrease. For example, when we begin learning to drive a car, we invest considerable effort in order to perform well, paying close attention to our every action and decision. We are usually aware that our performance can be easily disrupted by relatively trivial distractions, such as someone talking to us. After some amount of practice, however, our skill level improves and, along with this, we no longer experience performing as being as effortful as before. We are now able to pay attention to concurrent events that previously would have disrupted us. (...) According to many authors, what has happened is that a number of the underlying components of the performance have become automatic, and it is this change that reduces the need for attention and effort. (Segalowitz 2003: 382-383)

Som Segalowtiz (2003: 387) påpeker, bør man ikke identifisere 'automatisk prosessering' med 'rask prosessering' ettersom automatisk prosessering er et bredere begrep, og omfatter en kvalitativ endring. N. Ellis (1997: 139) poengterer at automatisering av noen prosesser, frigir oppmerksomhetsressurser slik at innlæreren kan konsentrere seg om betydningen av budskapet (enten når hun vil forstå en ytring, eller produsere en ytring selv), og ikke bare dets form. Gass og Selinker (2008: 230) formulerer det slik:

Because of the limited capacity that humans have available for processing, the more that can be handled routinely - that is, automatically - the more attentional resources are available for new information. (Gass og Selinker 2008: 230) 
Det at mennesker har begrenset prosesseringskapasitet er en generell egenskap ved menneskets kognisjon, dets hukommelse og læringsmuligheter (Pienemann 2003: 679). Automatisering er forbundet med tilegnelsen av et S2 og utviklingen av andrespråkkunnskaper (Segalowitz \& Hulstijn 2005: 384), og kan i denne sammenhengen defineres som:

Generally, automaticity refers to the absence of attentional control in the execution of a cognitive activity, with attentional control understood to imply the involvement, among other things, of intention, possibly awareness, and the consumption of cognitive resources, all in the service of dealing with limited processing capacity (Kahneman 1973, referert i: Segalowitz \& Hulstijn 2005: 371)

Automatisering av prosessering er viktig i S2-tilegnelse på grunn av at den fører til restrukturering. Som Gass og Selinker (2008: 234) forklarer, innebærer den kvalitative endringen, som automatisering er, en endring av innlærerens interne representasjoner av $\mathrm{S} 2$ og prosedyrer hun gjennomfører (fra mindre til mer effektive). På dette punktet er S1- og S2-tilegnelse like, og i begge tilfeller kan restrukturering beskrives på følgende måte:

Restructuring is characterized by discontinuous, or qualitative, change as the child moves from stage to stage in development. Each new stage constitutes a new internal organization and not merely the addition of new structural elements. (McLaughlin 1990: 117)

McLaughlin minner også om at selve restruktureringsbegrepet viser til Jean Piaget - en utviklingspsykolog som forsket på hvordan strukturelle endringer i det kognitive systemet fører til kognitiv utvikling (ibid.). Gass og Selinker (2008: 234) understreker at det må foregå en restrukturering av systemet for at et nytt element kan innføre en endring i systemet. Det er altså ikke nok å kun legge til det nye elementet. For å oppnå en ny kvalitet, er restrukturering nødvendig. 
Restrukturering av mellomspråket (og også av morsmålet) er forbundet med såkalt U-formet læring som kan defineres som «the appearance of correct, or nativelike, forms at an early stage of development which then undergo a process of attrition, only to be reestablished at a later stage» (Sharwood Smith \& Kellerman 1989: 220). Det er flere årsaker til at innlæreren kan bruke strukturene hun allerede kan godt ukorrekt: hun kan for eksempel være trøtt eller befinne seg i en kommunikativt anstrengende situasjon. Det er også sannsynlig at det skjer når innlæreren går over fra kontrollert til automatisk prosessering (ibid.). Etter 'feilfasen' begynner innlæreren igjen å bruke den gitte formen korrekt. Ifølge Lightbown (1983) forekommer U-formet læring når innlæreren først blir kjent med en struktur, og klarer å mestre den, så blir hun kjent med en ny struktur, der hun må lære seg å skjelne mellom den gamle og den nye strukturen (noe som skjer på bekostning av korrekthet), for å til slutt komme tilbake til den riktige bruken av den gamle strukturen. Ortega imidlertid minner om at det er en forskjell mellom den første og siste korrekte fasen:

That is, in U-shaped learning curves, the linguistic products of the final phase cannot be distinguished from those of the first phase, as both are seemingly error-free. However, the underlying representations at the two times are qualitatively different. In the first phase, accuracy is purely coincidental, because it lacks the full representation of target-like functions and meanings that underlies the final phase. (Ortega 2013: 118).

En teori som forener prosesseringsbegrepet med utviklingsmønstre (utviklingsmønstre er omtalt i den neste seksjonen) i mellomspråk, er processability theory (PT) utarbeidet av Manfred Pienemann, og presentert i sin helhet i boken Language processing and second language development; Processability theory (Pienemann 1998). Der gjør han greie for PT på følgende måte: 
... a theory which adds to learnability theory the perspective of processability; i.e. "processability theory". In my view, the logicomathematical hypothesis space in which the learner operates is further constrained by the architecture of human language processing. Structural options that may be formally possible, will be produced by the language learner only if the necessary processing procedures are available that are needed to carry out, within the given minimal time frame, those computations required for the processing of the structure in question. (Pienemann 1998: 1)

Pienemann (2003: 686) framhever at en innlærer bare kan forstå og produsere de S2-formene som hennes språklige prosessor tillater når hun er på det språknivået som hun er. Grammatisk informasjon som kan bli prosessert av en innlærer, kan ordnes $i$ et hierarki fra de lettest prosessbare til de som krever mest prosessering. Hierarkiet ser slik ut (Pienemann 2003: 689):

1. lemma access

2. the category procedure

3. the phrasal procedure

4. the S-procedure

5. the subordinate clause procedure, if applicable

Det betyr at innlærere først kan prosessere bare enkeltord, etterpå klarer de å bøye dem innenfor samme ordklasse (f.eks. kan de legge til en flertallsmorfem til substantivet), så er de i stand til å danne fraser der elementer passer til hverandre (f.eks. kan de bruke riktig determinativ i samsvar med substantivet det står til). Senere kan de produsere hele korrekte setninger, og til slutt også leddsetninger. Pienemann (2003: 690) selv legger til at det dreier seg om et hierarki her hvor hver neste steg forutsetter tilstedeværelse av den forrige prosedyren. Innlæreren må først legge til et nytt ord i sitt ordinventar før hun kan tilskrive ordet en riktig grammatisk kategori, og forst da kan hun klare å danne en frase med det gitte ordet. 
Som Pienemann (2005) selv innrømmer, baserer PT seg på undersøkelser gjennomført på to beslektete språk: engelsk og tysk, og teorien krever bevis fra flere ulike språk før den kan tas som universelt gjeldende. Av den grunn har PT blitt testet på flere språk og grammatiske kategorier, blant annet svensk morfosyntaks (Pienemann \& Håkansson 1999), og adjektivisk samsvarsbøyning i skandinaviske språk (Glahn mfl. 2001, Hammerberg 1996). Undersøkelsen til Glahn, Håkansson, Hammerberg, Holmen, Hvenekilde \& Lund (2001) er bredere omtalt i underkapittelet om tilegnelse av kongruens, men her vil jeg si at resultatene av deres undersøkelse bekrefter prediksjoner gitt av Pienemann (1998) om at: «Phrasal morphology is acquired before interphrasal morphology, which again is acquired before the preverbal position of the negation in subordinate clauses» (Glahn, Håkansson, Hammerberg, Holmen, Hvenekilde \& Lund 2001).

Et annet interessant aspekt ved PT er hvordan den kan kombineres med transfer fra S1. Innledningsvis i denne seksjonen har jeg allerede nevnt at muligheten til å prosessere en gitt struktur kan begrense forekomst av tverrspråklig innflytelse, noe som Pienemann, Di Biase, Kawaguchi og Håkonsson (2005b) har gitt bevis på. I en annen artikkel har Pienemann, Di Biase, Kawaguchi og Håkansson (2005a) undersøkt hypotesen om at bortsett fra at transfer begrenses av prosesseringsmuligheter, er begynnerfasen i S2 ikke lik sluttfasen i S1. Som konklusjon av flere undersøkelser gjennomført på flere S1-S2kombinasjoner påstår Pienemann Di Biase, Kawaguchi og Håkansson (2005a: 111) at strukturene som er høyere oppe i prosesseringshierarkiet aldri blir overført i begynnerfasen, uansett hvor nært eller lite beslektet språkene er. Prosesseringskapasitet hos den enkelte innlæreren spiller altså en viktig rolle i å velge (ikke nødvendigvis på en bevisst måte) hva som kan overføres fra et språk til et annet, noe som også Ortega (2013: 33-34) har lagt merke til, som nevnt ovenfor. 


\subsubsection{Utviklingsmønstre i mellomspråk}

En annen karakteristikk ved mellomspråk, som er sterkt forbundet med prosessering, er forutsigbare utviklingssteg utviklingsmønstre. Man snakker da om laeringsrekkefølge (order of acquisition) og loeringsløype (sequence of acquisition). Ofte er læringsrekkefølge og -løype omtalt som ett fenomen, og forstått slik at læringsløypen er en underkategori av læringsrekkefølgen. Fenomenet blir undersøkt av Krashen og omtalt slik:

One of the most exciting discoveries in language acquisition research in recent years has been the finding that the acquisition of grammatical structures proceeds in a predictable order. Acquirers of a given language tend to acquire certain grammatical structures early, and others later. The agreement among individual acquirers is not always $100 \%$, but there are clear, statistically significant, similarities. (Krashen 1982: 12)

Dette funnet er viktig fordi det sier at S2-innlærere tilegner seg nye strukturer når de er klare for det, og ikke nødvendigvis direkte etter at de har vært undervist i dem (Dulay, Burt \& Krashen 1982: 200). Dette går i samsvar med Krashens Comprehensible Input Hypothesis (1985) som sier at:

The Input Hypothesis claims that humans acquire language in only one way - by understanding messages, or by receiving 'comprehensible input'. We progress along the natural order (hypothesis 2) by understanding input that contains structures at our next 'stage' - structures that are a bit beyond our current level of competence. (We move from $i$, our current level, to $i+1$, the next level along the natural order, by understanding input containing $i+1 \ldots$ ). (Krashen 1985: 2)

Læringsløype er forskjellig fra læringsrekkefølgen med at den gjelder tilegnelsen av kun én struktur, det er en slags intern læringsrekkefølge som finner sted innen én struktur. Berggreen 
og Tenfjord definerer læringsløype som: «En rekke overgangsformer på veg mot målspråksstrukturen, en slags gradvis mestring av et fenomen» (Berggreen \& Tenfjord 1999: 184).

Som allerede nevnt i seksjonen om mellomspråk, er det å følge en læringsrekkefølge når man lærer et språk, et generelt fellestrekk ved mellomspråk. Goldschneider og DeKeyser (2001) skriver at:

Some researchers in this area have posited a "natural" order of acquisition common to all $\mathrm{ESL}^{10}$ learners irrespective of age, learning environment, or prior languages learned (2001:2).

I henhold til Goldschneider og DeKeyser (2001) er læringrekkefølge universell for alle andrespråksinnlærere av samme språk, uavhengig av deres S1-bakgrunn, og uavhengig av andre språk de har tilegnet før. Det som transfer (fra de allerede tilegnete språk) imidlertid kan ha påvirkning på i dette tilfellet, er tiden brukt på å mestre et gitt trekk, S1 (eller et S3) kan virke fordelaktig og føre til at man bruker kortere tid for å tilegne seg et S2 (eller en viss struktur i S2), eller det kan virke hindrende og resultere $i$ at man trenger lengre tid for å tilegne seg et S2 (eller en viss struktur i S2).

Studier på «den naturlige læringsrekkefølgen» har blitt ført på både andre- og førstespråktilegnelsen, og ifølge Dulay, Burt og Krashen (1982: 209) er tilegnelse av S1 og S2 like:

Both comparisons showed that the contours for the acquisition sequences of the children and adults studied are very similar. This initial sequence study of adult morpheme acquisition permits us to suggest that whatever internal factors are interacting with language input in children to produce the results we see, they seem to be operating in adults as well. (Dulay, Burt \& Krashen 1982: 209)

I norsk ASL-forskning er læringsløyper og -rekkefølger utforsket i relativt liten grad. Et forsøk på å bestemme en læringsløype i norsk har Sørland (2010) foretatt seg. I sin studie

${ }^{10} \mathrm{ESL}$ - English as a second language. 
på utviklingen av substantivfraser utpeker han fem faser norskinnlærerne på begynnernivå går gjennom. Disse fasene er:

Fase 1: Ikke utbyggete substantivfraser - NP-er som består av kun kjerne.

Fase 2: Frasetyper som består av artikkel eller tallord + kjerne.

Fase 3: Frasetyper som består av possessiv eller beskriver + kjerne.

Fase 4: Frasetyper som består av demonstrativ + kjerne. Dessuten: Flere ledd framfor kjernen (særlig: bestemmer + beskriver + kjerne), og: etterstilte underledd (possessiver og enkle relativsetninger)

Fase 5: Frasetyper som inneholder «tunge» adledd etter kjernen (preposisjonsfraser, relativsetninger og infinitiver).

Sørlands (2010) studie av mestring av substantivfrasene tar imidlertid ikke hensyn til morfologien til substantivfraser, og konsentrerer seg kun om ordstillingen. I norsk ASL har studier av læringsrekkefølgen av inversjon vært mest populært. Blant annet tok Hagen (1992), Carlsen Toledo (1995) og Johansen (2007) seg av dette spørsmålet, og undersøkte feil-, under- og overinversjon i norske mellomspråk. I Skandinavia har svenske lingvister lenge vært opptatt av utviklingsmønstre i mellomspråks ordstilling. De to mest utforskede områdene er der: negasjon (bl.a. Hyltenstam 1977) og relativsetninger (bl.a. Hyltenstam 1984, Viberg 1987).

Utviklingsmønstre i mellomspråk kan også beskrives fra et mer globalt perspektiv, det vil si som utviklingsnivåer, siden det sies at: «Et svært generelt utviklingsmønster er at mellomspråk beveger seg fra å være 'svake' i retning til å bli 'sterke' over tid» (Berggreen \& Tenfjord 1999: 169), og med dette menes at mellomspråk utvikler seg fra å være mindre til fullt utbygget. Ved andrespråktilegnelsen er det vanskelig å påpeke hva startpunktet av utviklingen er siden selve forstespråkkunnskapen kan vurderes å være starten. Videre snakkes det ofte om stille / taus periode, begynnervarigheten, basisvarigheten, og sluttnivået som enten kan være uatskillelig fra målspråket i førstespråksvarianten (dvs. at det har oppstått et målspråksnært 
fullt utbygget system), eller tilegnelsen kan stoppe opp uten at noen målspråksnær kompetanse er oppnådd, og da snakker man om stagnasjon og fossilisering.

\subsubsection{Språkslæringsprosessen}

I kognitive teorier er sinnet ofte sammenliknet med en datamaskin fordi prosessesene som står bak språklæringen, det vil si språkbearbeiding og -oppbevaring av språklige ytringer, minner om prosessene som datamaskiner utfører. Man snakker da altså om computational model of learning hvor sinnet er kalt 'en svart boks': "The 'black box' houses some kind of apparatus that extracts information from the 'input', works on it, stores it, and subsequently uses it in 'output'» (R. Ellis 2012: 61). Andrespråkstilegnelse kan følgelig framstilles i form av en figur:

innputt (input) $\rightarrow$ inntak (intake) S2-kunnskap $\rightarrow$ ytring (output)

Figur 1: En 'computational' modell av S2-tielgense (hentet fra R. Ellis 2012: 35)

Som R. Ellis (ibid.) poengterer, foregår de to innerste prosessene (som er satt i en ramme i Figur 1) inne i sinnet på innlæreren, mens de to ytterste prosessene (utenfor rammen) er observerbare av andre. Innputt er definert som «the language to which learners were exposed» (Gass \& Selinker 2008: 304), og er forskjellig fra inntak slik at det sistnevnte refererer til kun den innputten som har blitt internalisert av innlæreren (Corder 1967: 165, Gass \& Selinker 2008: 305). Inntaket blir så til andrespråkskunnskap, som kan erfares av andre i form av ytringer.

Ifølge Færch og Kasper (1980: 64-65) danner S2innlæreren sine hypoteser om andrespråket på grunnlag av innputten for å senere teste dem i sine ytinger, som er resultatet av både mellomspråkssystemet, og bruken av lærings- og kommunikasjonsstrategier. Færch og Kasper understreker at: 
«The main process in $\mathrm{IL}^{11}$ rule formation are the formation and testing out of hypotheses about a specific L2 rule» (Færch \& Kasper 1980: 65). Som de påstår (ibid.: 67), er tilbakemeldingen innlæreren får fra samtalepartneren, kilde til et nytt inntak, som i sin tur fører til at de testete hypotesene enten blir bekreftet, eller forkastet, avhengig av samtalepartnerens feedback, noe som igjen fører til endringer i mellomspråkssystemet. Hele denne prosessen er presentert i Figur 2. Inntaket kommer altså fra to kilder: innputten (slik får innlæreren ny viten om S2), og fra tilbakemeldingen(e) på den ytringen hun har produsert, basert på hypotesene dannet på de allerede eksiterende S2-kunnskapene.

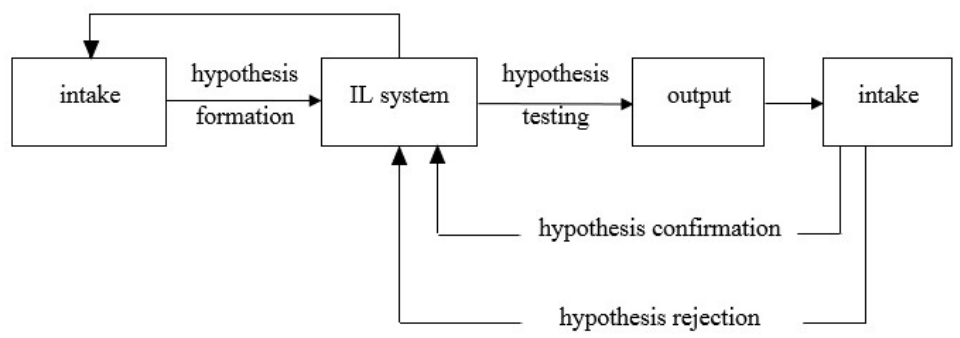

Figur 2: Formering av et mellomspråksregel (hentet fra Farch \& Kasper 1980:66)

To ting er spesielt interessante i denne sammenhengen: det hvordan innputt blir til inntak, og det som utgjør grunnlaget for språkinnlærerens hypotesedannelser. Hva slags innputt som kan bli til inntak, har allerede blitt nevnt ovenfor i seksjonen om utviklingsmønstre i mellomspråket der det har vært presentert Krashens Comprehensible Input Hypothesis (1985). Andre faktorer som kan listes opp her, er av både psykolingvistisk art (innlærernes viten om naturlige språk og verbal kommunikasjon, hennes spesifikke viten om strukturen i S1 og om målspråket, alle typer ikke-språklig viten, hukommelse) og

${ }^{11} \mathrm{IL}$ - interlanguage (mellomspråk). 
strukturell art, der saliens og frekvens spiller hovedrollen (Berggreen \& Tenfjord 1999: 90-94).

Den generelle betydningen saliens (salience) har, beror på at et trekk er iøynefallende og påfallende, og derfor mer synlig og lettere å legges merke til (Rácz 2013: 23). Mennesket har en alminnelig tendens til å legge merke til og huske start- og sluttenhetene, for eksempel de første og siste elementene i setningen (Garman 1990: 184). I ASL er det vanlig å betrakte saliens som 'the availability of input' (Bardovi-Harlig 1987, Gass \& Selinker 2008: 145). R. Ellis (1994: 379) understreker imidlertid at: «salience refers to the intensity of the subjective experience of stimuli, not of the objective intensity of the stimuli themselves».

Det er en generell forutsetning at «high-frequency constructions are more readily processed than low-frequency ones» (N. Ellis 2006: 102). Frekvente ord og strukturer er lettere å bli oppfattet og gjenkjent (Berggreen \& Tenfjord 1999: 95), noe som logisk sett fremmer læringen. Det har vært mye diskusjon om hvor mange ganger et ord må gjentas før det læres, og Golden (2009: 144) nevner at det vanlige tallet er seks til sju ganger. Gregg (2003: 847) unngår å angi noen tall, men han påstår at «Training takes time, and since the input is the trainer, that means a good deal of input is needed». R. Ellis poengterer imidlertid at:

Overall there is very little evidence to support the claim that input frequency affects L2 acquisition but there is very little evidence to refute it. Perhaps the safest conclusion is that input frequency serves as one of the factors influencing development, often in association with other factors such as L1 transfer and communicative need. (R. Ellis 1994: 273)

Gass og Mackey (2002: 257) framhever at frekvens alene ofte har liten påvirkning på tilegnelse, og først når den kombineres med andre faktorer, kan den sies å fremme læringen. Særlig saliens er en faktor som enten kan oppheve frekvensens innflytelse - i tilfellet når høyfrekvente ord er lite 
saliente, for eksempel artikler (Berggreen \& Tenfjord 1999: 96), eller den kan forsterke dens innflytelse - i tilfeller når høyfrekvente ord er høyt saliente. Man kan altså konkludere med Jarvis og Pavlenko at:

Concerning learning, the frequency, recency, and salience of a structure tend to increase the likelihood that the structure will be integrated into the person's language knowledge. (Jarvis \& Pavlenko 2008: 186)

Når det gjelder recency som Jarvis og Pavlenko nevner, har den ifølge dem påvirkning på hvilket språk som blir kilde til tverrspråklig innflytelse. De hevder at «the languages that the person has used recently tend to bear a high level of activation in the person's mind» (Jarvis \& Pavlenko 2008: 185), og av den grunn er mer sannsynlige å bli kilde til transfer.

Hvilke prinsipper som ligger til grunn for hypotesedannelse, har Slobin (1985) og Andersen (1990) vært opptatt av. Mens Slobin har undersøkt generelle prinsipper for hypotesedannelse i førstespråktilegnelsen, har Andersen (1990) fokusert på å tilpasse Slobins funn til andrespråktilegnelsen. Andersen beskrev sju kognitive operasjonsprinsipper for andrespråkslæring: én-til-én-prinsippet, multifunksjonalitet, formell determinisme, distribusjonell skjevhet, prinsippet om motiverte overføringer ('transfer to somewhere principle'), relevans og releksifisering. Ved hjelp av disse prinsippene kan man beskrive hvordan en S2-innlærer segmenterer elementer fra innputten, og danner hypoteser om målspråket ved hjelp av sin kognitive evne til å resonnere. For eksempel er én-til-én-prinsippet et overgeneraliseringsprinsipp, og sier at kun én mening er tilskrevet én form (Andersen 1984: 79).

\subsubsection{Oppsummering}

Kognitive teorier om ASL betrakter innlæreren som en aktiv konstruktør av grammatikken, og sammenligner hennes sinn med en datamaskin der prosessering finner sted. Sammen 
med tverrspråklig innflytelse spiller prosessering en vesentlig rolle i utviklingen av mellomspråket. Prosesseringsmuligheter er dessuten avgjørende når det gjelder utviklingsmønstre i mellomspråket siden læringsrekkefølgen avhenger av hva som kan prosesseres på det gitte tidspunktet. Transfer kan i sin tur enten fremskynde eller utsette tilegnelse av den gitte strukturen. Både i tilegnelsesprosessen og ved tverrspråklig innflytelse er det en rekke faktorer som gjør at en gitt struktur blir prosessert fortere enn en annen, eller som heller blir overført framfor en annen struktur. Disse prosessene er av både rent lingvistisk og psykolingvistisk slag. Det er også en del sosiale faktorer som også påvirker innlæreren i læringsprosessen, og de er drøftet i et separat underkapittel.

\subsection{Sosiale faktorer}

Bortsett fra de psykolingvistiske faktorene som spiller en rolle i S2-tilegnelse, det vil si hovedsakelig prosessering og transfer (som er blitt behandlet ovenfor), og de typisk lingvistiske faktorene, finnes det også en rekke andre faktorer som jeg vil omtale som 'sosiale' her. Termen 'sosiale' bruker jeg her i generell betydning, og denne betegnelsen innebefatter alle de faktorene som verken kan innordnes i det kognitive nivået ved andrespråkslæring (dvs. til de psykolingvistiske faktorene), eller i det rent lingvistiske nivået. Fordi antallet slike 'sosiale' faktorer er stort, vil jeg konsentrere meg bare om et utvalg av dem: generelle S2-kunnskaper (målt i CEFR-nivåer), alder, utdanning, daglig bruk av S2, antall kurstimer i S2, oppholdstid i S2-landet, S3-kunnskaper. $\AA$ drøfte S3-kunnskaper kan virke malplassert, og kanskje passer det bedre å omtale dem i underkapittelet om kognitive teorier $\mathrm{i}$ andrespråkslæringen. Det at de likevel blir omtalt her, skyldes metodologiske grunner. I analysen blir S3-kunnskaper behandlet på lik måte med de andre faktorene nevnt ovenfor. 


\subsubsection{Generelle S2-kunnskaper}

Det kan virke selvklart at med økende generelle S2kunnskaper, øker også korrektheten i S2, og mellomspråket likner stadig mer på målspråket. Det er imidlertid ikke alltid tilfellet ettersom det for eksempel kan forkomme en U-formet læring, et fenomen beskrevet av blant annet Sharwood Smith og Kellerman (1989: 220) og Lightbown (1983) framstilt i prosessering-seksjonen ovenfor.

Nå for tiden er det vanlig å bruke Det felles europeiske rammeverket for språk (eng. Common European Framework of Reference for Languages: Learning, teaching, assessment, fork. CEFR), referert til som Rammeverket som referansegrunnlag for språkferdighetsnivåer. Rammeverket har blitt utarbeidet av Europarådet siden 1971, og i 2007 ble det oversatt til norsk. Det skilles ut seks ferdighetsnivåer i Rammeverket, gruppert i par: ferdighetsnivåene $\mathrm{A} 1$ (gjennombrudd) og $\mathrm{A} 2$ (underveis) brukes for begynnernivå, ferdighetsnivåene B1 (terskel) og B2 (oversikt) for selvstendig nivå, og ferdighetsnivåene C1 (effektiv språkbruk) og $\mathrm{C} 2$ (full mestring) for avansert nivå (Rammeverket 2011: 26). Som Carlsen legger merke til, er beskrivelsene av ferdighetsnivåene:

Positive formuleringer av hva innlærerne kan gjøre med språket, såkalte 'can do'- statements eller 'jeg kan'-utsagn, og i mindre grad beskrivelser av hva innlærere ikke kan gjøre. (Carlsen 2010: 135)

Grunnlaget for Rammeverket er et kommunikativt språksyn, og det stilles i fokus ikke bare rent lingvistiske kompetanser der, men også sosiolingvistiske og pragmatiske (ibid.). Fordi Rammeverket beskriver generelle (dvs. ikkespråkspesifikke) kompetanser og ferdigheter, er det lettere å sammenligne innlærere av flere ulike språk med hverandre i forskningen ettersom et gitt ferdighetsnivå er det samme på tvers av språk. Og slik er for eksempel nøyaktighet ved muntlig språkbruk beskrevet i Rammeverket: 
A1-nivå: Viser bare begrenset kontroll over noen få, enkle grammatiske strukturer og setningsmønstre som hun/ han har lært utenat.

A2-nivå: Bruker noen enkle strukturer korrekt, men gjør systematisk elementære feil.

B1-nivå: Har et repertoar av frekvente fraser og setningsmønstre knyttet til kjente situasjoner og kan bruke det på en forholdsvis korrekt måte.

B2-nivå: Viser relativt stor grad av grammatisk kontroll. Gjør ikke feil som fører til misforståelser, og kan rette de fleste av sine feil.

C1-nivå: Viser gjennomført høy grad av grammatisk kontroll. Feil er sjeldne og vanskelige å oppdage. Når feil forekommer, blir de stort sett rettet opp.

C2-nivå: Bruker et komplekst språk med gjennomført grammatisk kontroll, selv når oppmerksomheten er rettet mot noe annet (f.eks.: når hun/han forbereder et utsagn, eller holder øye med andres reaksjoner).

(Rammeverket 2011: 36)

Det er synlig at korrekthet blir utviklet av innlæreren fra 'elementære feil', gjennom 'forholdsvis korrekte' former til full 'grammatisk kontroll'. En innlærer på et høyere CEFR-nivå bruker altså språket generelt mer korrekt (dvs. målspråkslikt) enn en innlærer på et lavere CEFR-nivå.

Det generelle ferdighetsnivået i S2 (og også i S1) har dessuten innflytelse på karakteren og omfanget av transfer $\mathrm{i}$ målspråket, ifølge Odlin og Jarvis (2004). Jarvis og Pavlenko i sin tur sier at «L2 effects are most visible in L2 users with high levels of fluency and proficiency» (Jarvis \& Pavlenko 2008: 201). De nevner i tillegg at ferdighetseffekter ser ut å være krumlinjete i tilfellet leksikalsk og morfologisk transfer og en jevn trend i områdene ordstilling og uttale (Jarvis \& Pavlenko 2008: 202). Også R. Ellis (1994: 332) foreslår at det kan antas at avanserte innlærere er i en bedre situasjon til å dra nytte av likhetene mellom S1 og S2 (f.eks. i vokabularområdet) enn mindre avanserte innlærere. Jarvis og Pavlenko påpeker at med økende mestring av målspråket, minsker negativ transfer, og positiv transfer øker: 
Although negative transfer seems ultimately to decrease with proficiency (though often nonlinearly and only to the point of stabilization), positive transfer may increase with gains in targetlanguage proficiency as learners become more aware of the similarities between the source and the target language and as they acquire the language abilities (e.g., vocabulary knowledge, grammatical competence, fluency, control) necessary for taking advantage of those similarities. (Jarvis \& Pavlenko 2008: 202-203)

Det finnes dessuten bevis på at språklig ferdighet påvirker tverrspråklig innflytelse både når det gjelder tilegnelsen og bruken av språket (R. Ellis 1994: 338, Jarvis \& Pavlenko 2008: 203). Guion, Flege og Loftin påviser at «The amount of L1 use, and thus perhaps L1 activation, also influences production capabilities in an L2» (Guion, Flege \& Loftin 2000a: 39). Pavlenko hevder at konsepter tilegnet i S2 er gjerne overført til S1 av innlærere som er avanserte i S2: «L2 effects on L1-based conceptual systems may be significantly more far-reaching and pervasive than adoption of new words and expressions») (Pavlenko 2000: 189). Hun har suggerert at S2-tilegnelse av voksne innlærere kan resultere i:

(a) internalization or borrowing of L2-based concepts,

(b) shift from an L1 to an L2 conceptual domain,

(c) convergence of two concepts into one, distinct from the concepts shared by the L I and L2 speech communities,

(d) restructuring, whereby new elements are incorporated into a previously existing concept,

(e) attrition of previously available concepts.

(Pavlenko 2000: 189)

Å tilegne et S2 fører altså til en konseptuell endring (Jarivs \& Pavlenko 2008: 153, Pavlenko 2000: 189), noe som påvirker både videre S2-tilegnelse og -bruk, bruken av S1, og generelt sett hele det kognitive systemet hos innlæreren. 


\subsubsection{Alder}

Alder er en av de mest diskuterte individuelle faktorene ved andrespråkslæring. I litteraturen er det to problemstillinger som kanskje har blitt omtalt mer enn de andre: grensen mellom S1og S2-tilegnelsen - ved hvilken årsalder den gjennomgås, og hvilken alder som er best for å lære seg et andrespråk. Et svar på det første problemet er Critical Period Hypothesis (CPH) definert av Birdsong som:

The $\mathrm{CPH}$ states that there is a limited developmental period during which it is possible to acquire a language be it $\mathrm{L} 1$ or $\mathrm{L} 2$, to normal, nativelike levels. Once this window of opportunity is passed, however, the ability to learn language declines. (Birdsong 1999: 1)

Allerede Lennenberg (1967: 176) har sett på CPH, og satt grensen mellom S1- og S2-tilegnelsen til puberteten. Etter puberteten kan, ifølge ham, et språk læres kun gjennom bevisst arbeid - som et fremmedspråk, og i denne situasjonen er det å oppnå morsmålslike kunnskaper svært vanskelig. Hovedforskjellen mellom S2-læringen hos barn og voksne ligger i strategier de (heller ubevisst) velger, og i hvorvidt tilegnelsen er suksessrik eller ikke (dvs. om man oppnår målspråkslike kunnskaper eller ei), uttrykker Bley-Vroman (1988) i sin Fundamental Difference Hypothesis. Basert på Bley-Vroman (1988) har R. Ellis (1994: 107) listet opp hovedforskjeller mellom barne- og voksenlæring. De er blant annet: oppnådd suksess i S2 av barn (og mye sjeldnere av voksne), fossilisering hos voksne (og ikke hos barn), barn utvikler klare intuisjoner om hva som er korrekt i S2 (mens voksne oftest ikke er i stand til det). Hos voksne er suksess i større grad avhengig av deres affekter, personlighet, motivasjon, holdninger (og det er ikke tilfellet hos barn).

Når det gjelder spørsmålet hvilken alder som er best for å lære seg et andrespråk, er det også forbundet med CPH (som i mindre radikal versjon kalles Sensitive Period Hypotheses, Gass \& Selinker 2008: 406), og kan ikke svares rett fram 
ettersom - som Snow og Hoefnagel-Höhle (1978) påstår: «Older is faster, but younger is better». På den ene siden er barn mye oftere suksessrike i S2 (i den forstand at de oppnår morsmålslike kunnskaper), men på den annen side lærer voksne seg S2 fortere enn barn, og de støtter seg oftere til eksplisitte kunnskaper, mens barn lærer seg et språk snarere implisitt (DeKeyser 2003: 335). DeKeyser sier at:

Children do better in terms of ultimate attainment because many elements of language are hard to learn explicitly (especially, of course, for those adults who have limited verbal ability); adults learn faster because their capacities for explicit learning let them take short cuts. (DeKeyser 2003: 335)

Tilstedeværelse av eller mangel på en kritisk periode ved språktilegnelse har dessuten vært stridens eple mellom kognitive og UG-baserte teorier om språktilegnelse, og ikke en gang generative teorier alene er enig om hvorvidt voksne S2innlærere har tilgang til UG. Man snakker altså om full tilgang, ingen tilgang, delvis tilgang og partiell tilgang (R. Ellis 2012: 69). I dag mangler det imidlertid redskaper som klart og tydelig kan tilføre bevis på at en kritisk alder for andrespråkslæring finnes, og hvor egentlig den finner sted.

\subsubsection{Utdanning}

Både ens utdanning og yrke har påvirkning på hvilken sosialklasse en tilhører (R. Ellis 1994: 204). Type utdanning man har, er i sin tur ofte avhengig av generell intelligens man rår over. IQ kan igjen påvirke språklig evne (R. Ellis 2012: 73), men det er ikke noe én-til-én forhold mellom IQ og språklig evne (Gass \& Selinker 2008: 420). Som R. Ellis og Gass og Selinker nevner, er det en korrelasjon mellom ens foreldres utdanningsnivå og sosialklasse og ens evne til og suksess i å tilegne seg et andrespråk slik at høyere utdanningsnivå og sosialklasse har en positiv påvirkning på både språkevne og suksess i S2 (R. Ellis 1994: 205, Gass \& Selinker 2008: 420). 
R. Ellis (1994: 206) nevner imidlertid at høyere sosialklasse går sammen med høyere språkferdigheter i S2 bare i tilfellet formell språkopplæring. Han forklarer at sosialklasse ikke har noen påvirkning på S2-tilegnelsen når opplæringen i S2 fokuserer på kommunikative ferdigheter.

$\AA$ ha mer utdanning er ofte forbundet med lengre S1opplæring, og derfor bedre S1-kunnskaper, noe som påvirker S2-tilegnelsen på en positiv måte, noe som blant annet Olshtain, Shohamy, Kemp og Chatow (1990: 23) har påvist. Ortega gir en oppsummering av temaet:

In the end, then, the conclusion reached by L2 aptitude scholars is that intelligence, first language ability and foreign language aptitude partially overlap because they all seem to share a substrate in which academic skills and grammatical sensitivity are implicated. However, the three constructs are sufficiently different from one another to be considered distinct and worthy of investigation, each on its own. (Ortega 2013: 152)

Utdanningen man har tatt, kan også indirekte påvirke ens læringsstrategier. Avhengig av hva og hvordan man har lært før, kan den også spille en rolle i hvordan man vil lære seg et andrespråk. Særlig det å kunne flere andrespråk ser ut å spille en viktig rolle i å utvikle visse læringsstrategier som også blir brukt i senere språklæring. Nayak, Hansen, Krueger og McLaughlin (1990: 221) skriver at: «people with multiple language skills have different language-acquisition strategies than do people with single language skills», og de hevder at bruken av læringsstrategier er bedre i dette tilfellet. Læringsstrategier skal forstås som «the learner's active contribution to enhancing the effectiveness of his or her own learning» (Dörnyei \& Skehan 2003: 607). Schmeck forklarer at læringsstil er forbundet med læringsstrategi, og skriver at:

In general, when a strategy is favored with a certain bias that ignores subtle variation in the situation, it suggests either the presence of a cognitive style or the presence of motives and 
personal experiences that affect perception and give rise to a stylelike orientation. Styles and motives reside within the person and relate to genetics and prior experience. (Schmeck 1988: 17)

\subsubsection{Antall kurstimer}

Det skilles i faglitteraturen mellom eksplisitt og implisitt språkopplæring. Mens eksplisitt språkopplæring skjer i klasserommet, finner implisitt læring sted i naturlig sammenheng utenfor klasserommet. N. Ellis forklarer forskjellen på eksplisitt og implisitt læring slik:

[Implicit learning is] acquisition of knowledge about the underlying structure of a complex stimulus environment by a process which takes place naturally, simply and without conscious operations. [Whereas explicit learning] is a more conscious operation where the individual makes and tests hypotheses in a search for structure. (N. Ellis 1994: 1)

Hulstijn (2005: 131) plasserer forskjellen på eksplisitt og implisitt læring i bevisst intensjon (som forekommer i eksplisitt og mangler i implisitt læring) i å undersøke regulariteter i innputten. Schmidt (1990: 129) påstår imidlertid at rollen bevisste og ubevisste prosesser spiller i S2-tilegnelse, er et av de mest kontroversielle problemene i ASL. For å klargjøre problemet, foreslår han å skille mellom tre betydninger av begrepet bevissthet: bevissthet som oppmerksomhet (consciousness as awareness), bevissthet som intensjon (consciousness as intention) og bevissthet som kunnskap (consciousness as knowledge). Schmidt (1990: 131-133) deler bevissthet som oppmerksomhet igjen opp i tre nivåer: persepsjon (perception) som er det laveste nivået, ensing (noticing), og forståelse (understanding) som er det høyeste nivået. Forståelig oppmerksomhet er adskilt fra ensing slik:

Noticing is the basic sense in which we commonly say that we are aware of something, but does not exhaust the possibilities. Having noticed some aspect of the environment, we can analyze it and 
compare it to what we have noticed on other occasions. We can reflect on the objects of consciousness and attempt to comprehend their significance, and we can experience insight and understanding. (Schmidt 1990: 132)

Bevissthet blir ofte forstått som intensjon selv om det godt er mulig å lære noe tilfeldig, det vil si uten å ha intensjonen for å lære (Schmidt 1990: 133). Dessuten snakker man ofte om bevissthet-ubevissthet $\mathrm{i}$ henhold til eksplisitt-implisitt viten, dvs. viten om regler om å bruke gitte språkfenomener versus viten om praktisk kunnskap for å bruke gitte språkfenomener (Schmidt 1990: 134).

Ortega har listet opp tre typer læring avhengig av kvaliteten på oppmerksomheten man legger i læringen:

1) Incidental - learning without intention, while doing something else,

2) Implicit - learning with no intervention of controlled attention, usually without providing rules and without asking to search for rules,

3) Explicit - learning with the intervention of controlled attention, usually summoned by the provision of rules or by the requirement to search for rules.

(Ortega 2013: 94)

DeKeyser (2003: 335-336) sier at det ikke finnes noe overbevisende bevis på at mennesker kan lære seg abstrakte regler uten å være bevisst dem, og for å lære abstrakte mønstre og bruke dem produktivt, må man være klar over dem.

Forskningen på instruert opplæring konsentrerer seg mye om hvilken innvirkning instruert opplæring i det hele tatt har på språktilegnelse (R. Ellis 2012: 79). Ifølge Pienemanns teachability hypothesis, «stages of acquisition cannot be skipped through formal instruction and that instruction will be beneficial if it focuses on structures from 'the next stage'»» (Pienemann 1998: 13). Men til tross for at instruksen ikke har 
innflytelse på selve læringsløypen og -rekkefølgen i S2-tilegnelsen, kan den påvirke tempoet innlæreren når til etterfølgende etapper (R. Ellis 2012: 81). Likevel hevder Norris og Ortega at:

Focused L2 instruction results in large target-oriented gains, that explicit types of instruction are more effective than implicit types, and that Focus on Form and Focus on Forms interventions result in equivalent and large effects. Further findings suggest that the effectiveness of L2 instruction is durable and that the type of outcome measures used in individual studies likely affects the magnitude of observed instructional effectiveness. (Norris \& Ortega 2000: 417-418)

\subsubsection{Oppholdstid i S2-landet og daglig bruk av S2}

I temaet daglig bruk av S2 understreker Gass at:

The early body of research as well as more recent work has taken as basic the notion that conversation is not only a medium of practice, but also the means by which learning takes place. In other words, conversational interaction in a second language forms the basis for the development of language rather than being only a forum for practice of specific language features. (Gass 2003: 234)

I det ovenfor siterte fragmentet refererer hun til Longs (1996: 451) Interaction Hypothesis som sier at forhandling av mening (negotiation of meaning) og negativ tilbakemelding (negative feedback) virker fordelaktig på utvikling av S2. Både forhandling av mening og tilbakemelding oppnår man i en interaktiv situasjon. Det kan derfor trekkes en konklusjon at bruken av S2 (jo oftere jo bedre), som oftest er forbundet med oppholdstid i S2-landet, fremmer S2-tilgenelsen. Denne konklusjonen har vært undersøkt og påvist av flere forskere, blant annet Flege, Birdsong, Bialystok, Mack, Sung og Tsukada (2006) som har vist at oppholdstid i Nord-Amerika virker positivt på uttaleevne hos S1-koreanske engelskinnlærere.

Det har også vært gjennomført en rekke studier angående effekten som oppholdstiden i S2-landet og bruken av S2 har på 
tverrspråklig innflytelse. Blant annet Guion, Flege, Liu og Yeni-Komshian (2000b) har vist korrelasjonen mellom oppholdstiden i Nord-Amerika og S1-transfer. Med økende oppholdstid, blir negativ S1-transfer redusert. Som Jarvis og Pavlenko (2008: 200-201) påpeker, er oppholdstid i S2-landet korrelert med type transfer. Jo lenger man oppholder seg i S2landet, desto mindre effekt har framovertransfer fra S1 på S2 (noe som er forbundet med språklig prosessering), og desto sterkere effekt har tilbaketransfer fra S2 på S1 (noe som er forbundet med tilegnelse av S2-strukturer og -konsepter).

Det er også et annet viktig aspekt ved effekten av oppholdstiden i S2-landet. Det viser seg at alder ved ankomst til S2-landet kan ha enda sterkere effekt både på tverrspråklig innflytelse og S2-tilegnelse generelt enn kun oppholdstiden (MacKay \& Flege 2004), noe som er i samsvar med Snow og Hoefnagel-Höhles (1978) påstand om at «younger is better», omtalt i alder-seksjonen ovenfor.

\subsubsection{S3-kunnskaper}

Allerede det å definere S3 - tredjespråk (eng. third language, fork. L3) byr på problemer ettersom S3 ikke nødvendigvis blir referert til som språk nummer tre $\mathrm{i}$ tilegnelsesrekkefølgen. Det er vanlig å bruke begrepet S3 til det språket som blir tilegnet etter at man allerede har tilegnet sitt førstespråk, og minst ett andrespråk (Hammarberg 2001: 22). Hammarberg skriver at: «It has been assumed that bi- or multilingualism is at least as frequent in the population of the world as pure monolingualism, perhaps even more frequent» (Hammarberg 2001: 21). Også Ortega nevner positiv effekt av det å kunne flere språk på S3-tilegnelse:

The accumulating evidence suggests that knowledge of two (or more) languages can accelerate the learning of an additional one. (...) The benefits are particularly clear if one of the previous languages is typologically related to the L3 (...). Ortega (2013: 48) 
Det er selvfølgelig flere faktorer som har påvirkning på hvilken språk som blir kilde for transfer til et S3. Blant de viktigste faktorene utpeker Cenoz psykotypologi:

Speakers borrow more terms from the language that is typologically closer to the target language, or using Kellerman's (1983) concept of psychotypology, the language that is perceived as typologically closer. (Cenoz 2001: 8)

Ytterligere faktorer som fører til at man overfører fra et og ikke annet kildespråk er ifølge Hammarberg (2001: 23): språkferdigheter (man overfører helst fra et språk som man kan best), recency (man overfører helst fra et språk som har nylig vært aktivert), og S2-status («there appears to be a general tendency to activate an earlier secondary language in L3 performance rather than L1», Hammarberg 2001: 23). Alle disse faktorene kombinert med de 'vanlige' faktorene som forekommer ved S2-tilegnelse, gjør studien på S3-tilegnelse enda mer kompleks (Cenoz 2001: 10). Situasjonen blir enda mer sammensatt siden «People who know more than two languages often exhibit transfer from multiple languages, even simultaneously» (Jarvis \& Pavlenko 2008: 205). Dette har alvorlige konsekvenser for metodologien (Odlin 2003: 473).

Ringbom (2001) presenterer i sin studie at kjennskap til et S2 som er nært forbundet med S3, danner et godt grunnlag for positiv transfer i produksjon, men fremfor alt i forståelse. Et område som er særlig godt overførbart, er vokabular. Imidlertid forblir S1 kildespråket for grammatisk transfer:

To conclude, then, L2-transfer in L3-production is manifested especially clearly in lexis. This primarily seems to be the result of cross-linguistic identification of similar single word forms, whereas the procedures involved in transferring semantic patterns and word combinations, like grammatical transfer, are nearly always L1-based, or at least presuppose L2-input or L2-proficiency closely approaching that of the L1. (Ringbom 2001: 67) 
Også Hammarberg og Williams (2009: 18) påstår at det å studere S3-tilegnelse kan være nyttig for å forstå hele tilegnelsesprosessen, og særlig rollen tverrspråklig innflytelse spiller i den.

\subsubsection{Oppsummering}

Det viser seg at alle de sosiale faktorene som har blitt omtalt ovenfor, kan ha påvirkning på tilegnelse av et andrespråk. Dessuten kan de kombineres med hverandre og med de lingvistiske og psykolingvistiske faktorene i ulik grad slik at det til slutt blir umulig å fullstendig utelukke de andre faktorene når man vil undersøke kun én, og det blir umulig å forutse i hvilken retning tilegnelse vil gå. Særlig tidligere tilegnete språk (S3kunnskaper) virker forvirrende ettersom hvert tidligere tilegnet språk samler i seg alle de andre faktorene slik at det oppstår flere nivåer av faktorer som i ulik grad og retning krysser hverandre og influerer på hverandre.

\section{$2.4 \quad$ Tilegnelse av kongruens}

Det er blitt gjennomført ulike studier angående tilegnelse av kongruens i S2. Både læringrekkefølge og tverrspråklig innflytelse har blitt tatt hensyn til i disse studiene. Dette underkapittelet skal ta for seg begge deler.

En av de viktigste bidragene til dette emnet er artikkelen til Glahn, Håkansson, Hammerberg, Holmen, Hvenekilde og Lund (2001). Forskerne har undersøkt hvordan Pienemanns prosessabilitetsteori (presentert i Prosesseringsseksjonen i underkapittelet om kognitive teorier i andrespråkslæring ovenfor) har seg $\mathrm{i}$ forhold til tilegnelsen av adjektivisk kongruensbøyning $\mathrm{i}$ skandinaviske språk $^{12}$. De har sammenlignet tilegnelse av adjektiviske attributter (intrafrasal informasjonsutveksling), adjektiviske predikativer (interfrasal informasjonsutveksling), og

12 Det betrakter norsk, dansk og svensk som ett språk siden de grammatiske strukturene de undersøker er like i alle de tre språkene. 
negasjon i leddsetninger (informasjonsutveksling mellom setninger), og undersøkt hypotesen, basert på PT, om at informasjonsutveksling først blir tilegnet innen fraser, så mellom fraser innen én setning, og til slutt mellom setninger. Hypotesen har blitt bekreftet, men forskerne har funnet et annet interessant resultat, nemlig at noen av de adjektiviske attributtene (som generelt sett tilegnes først blant de tre undersøkte strukturene) blir tilegnet etter andre adjektiviske attributter, og til og med etter negasjon i leddsetninger. Kategorien som blir lært først er tall, og kategorien som blir lært sist er genus ${ }^{13}$. Dette resultatet har blitt forklart med at flertall i skandinaviske språk velges på grunnlag av det konseptuelle innholdet av utsagnet (man bruker flertallsformer når det $\mathrm{i}$ virkeligheten dreier seg om flere enn ett eksemplar av det gitte objektet), mens genus kun er et morfologisk trekk uten noe konseptuelt innhold (dvs. at den ikke gjenspeiles i virkeligheten, og derfor må den læres og huskes), unntatt noen få substantiver som betegner levende vesener. Derfor har forskerne dratt ut følgende konklusjon av sin studie:

In sum, number agreement and gender agreement present the learner with different tasks, owing to the different nature of these morphological categories. Whereas learners can intend singular or plural, they have to know whether the noun is uter or neuter. Unlike the number category, the lexical gender of most nouns (including the ones we have used) has no simple and obvious semantic basis. (Glahn mfl. 2001: 402)

Disse resultatene er felles med det Lichtman (2009) har fått i sin studie. Hun har undersøkt S1-engelskspråklige spanskinnlæreres sensitivitet til adjektivkongruens i spansk. Spansk krever samsvarsbøyning av adjektiver både $\mathrm{i}$ attributiv og $\mathrm{i}$ predikativ posisjon i to kategorier: numerus (som har to trekk: singularis og pluralis), og genus (som også har to trekk: maskulinum og femininum). Det som kjennetegner syntaksen

${ }^{13}$ Glahn mfl. (2001) har sett bort fra bestemthetsbøyning ved adjektiver. 
av spanske substantivfraser, er adjektivets plassering bak substantiver. Lichtman (ibid.) undersøkte informantenes ${ }^{14}$ godkjenningsvurderinger av korrekt og ukorrekt bøyde adjektiver i fire posisjoner: attributive adjektiver som kommer rett etter substantivet de betegner (steg 1), predikative adjektiver som kommer etter kopulaverbet (der er det en 1-ords distanse mellom substantivet og adjektivet; steg 2), predikative adjektiver med 4-ords distanse (steg 3), og adjektiver i relativsetninger, også med 4-ords distanse (steg 4). Resultatene Lichtman har fått, bekrefter Pienemanns PT. Alle informantene prestere dårligere med økende distanse mellom adjektivet og kontrolløren. Informantene på begynnernivået frafalt allerede etter steg 1 (der det er overgang fra intra- til interfrasal informasjonsutveksling ifølge PT), og informantene på mellomnivået frafalt etter steg 3 (der det er overgang fra interfrasal informasjonsutveksling til informasjonsutveksling mellom setninger). Lichtmans (ibid.) resultater støtter i tillegg påstanden til Bock og Miller (1991) og Haskell og MacDonald (2005) om at det kan forekomme feil i kongruens mellom elementer som står langt fra hverandre i ytringen (også hos morsmålsbrukere av et språk).

Et annet perspektiv antok Axelsson (1994) i sin doktoravhandling der hun blant annet undersøkte tilegnelse av adjektivets morfologi i S2 svensk av finske, polske og spanske morsmålsbrukere. Hun klarte å oppdage en læringsløype i tilegnelse av svensk adjektivbøyning. Resultatet hun fikk var at svenskinnlærerne i begynnelsen overbrukte ubøyde adjektivformer, for så å mestre $a$-endelsen (som i norsk tilsvarer $e$ endelsen), og til slutt tilegnet de seg $t$-endelsen. Axelsson la også merke til at de ulike S1-gruppene mestret adjektivets morfologi i ulik grad - de S1 finske svenskinnlærerne performerte best, og de spanske - verst.

${ }^{14}$ Lichtman (2009) har sammenlignet to grupper informanter: S1-engelskspråklige spanskinnlærere på begynnernivå, og på mellomnivå. Som kontrollgruppe hadde hun S1-spanskspråklige personer. 
Tilegnelse av adjektivisk kongruens ser også ut å være forbundet med tilegnelse av kategoriene adjektivene blir bøyd i, det vil si i tilfellet norsk: numerus, genus og bestemthet. En rekke studier fokuserer på disse kategoriene, og de nyeste undersøkelsene angående tilegnelsen av genus- og bestemthetskategorien i norsk er tre doktoravhandlinger under arbeid: av Ragnhildstveit (genus), Johansen (definitthet) og Nordanger (definitthet). Studien til Ragnhildstveit og Nordanger tar utgangspunkt i deres masteroppgaver der de drøftet tilegnelsen av de samme kategoriene som i doktoravhandlingene, det vil si respektivt genus og definitthet. En kort oversikt over studiene om genus- og bestemthetskategorien befinner seg i seksjonene nedenfor. Til slutt presenteres en annen studie om adjektivtilegnelse - den gjelder imidlertid adjektivets semantikk.

\subsubsection{Tilegnelse av genus}

Ragnhildstveit (under arbeid) påpeker at verken det å ha et morsmål med lik genussystem som norsk eller det å ha et morsmål uten genus $\mathrm{i}$ det hele tatt virker fordelaktig på tilegnelse av kjønnskategorien i norsk. Likevel spiller morsmålstransfer en rolle i genustilegnelse i S2 norsk slik at innlærere som har et morsmål uten noe genussystem oftere unngår artikler (og gjør dermed feil) enn innlærere som har et genussystem i sitt morsmål. Det er en forklaring til hvorfor de vietnamesiske norskinnlærerne viser underproduksjon av artikler i forhold til de tyske innlærerne. De to morsmålsgruppene gjør imidlertid like mange feil i genusfordelingen i norsk.

Franceschina (2005) sammenligner genustilegnelse hos S1- og S2-innlærere, og kommer til konklusjonen at:

Children acquiring languages with grammatical gender as their L1 show remarkable speed and very few developmental errors compared to adult L2 learners. More importantly, normal L1 learners always achieve mastery of the gender systems of their L1, while many adult L2 learners do not. (Franceschina 2005: 114) 
Det er imidlertid noen likheter mellom genustilegnelse i første- og andrespråk. Generelt sett er genuskongruens tilegnet bedre (mer korrekt) når det gjelder determinativer i sammenligning med adjektivisk genuskongruens (ibid.). Bartning (2000), som undersøker genustilegnelse i fransk som S2, har funnet at: «(...) Gender on the definite determiner is acquired before the indefinite determiner, and the masculine before the feminine» (Bartning 2000: 225). Årsaken til at de feminine formene er tilegnet sist i S2 fransk er prosesseringsmessige - hunkjønnsformene er lengre, mer komplekse og ofte uregelmessige, og av den grunn vanskelige å prosessere (Bartning 2000: 236). Dewaele og Véronique (2001) gir i sin tur evidens for at antall feil i genuskongruens blir mindre med økende generelle andrespråkskunnskaper.

Tilegnelsen av genus i et S2 viser seg å være en sammensatt prosess som består av flere etapper - den har en viss læringsløype. Det er i tillegg flere faktorer som påvirker genustilegnelsen, og som gjør den enda mer sammensatt. En av disse faktorene er transfer som ikke nødvendigvis kommer til syne i form av feil, men for eksempel i form av underproduksjon av artikler, som Ragnhildstveit (under arbeid) viser i tilfellet S1 vietnamesiske norskinnlærere.

\subsubsection{Tilegnelse av bestemthet}

Nordanger (2009) prøvde å forklare de russiskspråkliges feil i bruk av bestemthetskategorien i norsk som S2 med konseptuell transfer, og Slobins «Thinking for Speaking»tilnærming ${ }^{15}$ (Slobin 1996). Konklusjonen Nordanger skrev, er følgende:

${ }^{15}$ Slobin har skilt ut en måte å tenke på som skjer rett før man uttaler seg - thinking for speaking (å tenke for å snakke) som han selv definerer som «A special form of thought that is mobilized for communication. (...) the activity of thinking takes on a particular quality when it is employed in the activity of speaking. In the evanescent time frame of constructing utterances in discourse one fits one ${ }^{\text {ee }}$ s thoughts into available linguistic frames » (Slobin 1996: 76). 
Jeg konkluderer videre med at Slobins "Thinking for Speaking" kan ha forklaringskraft for resultatene i den russiske gruppen, vanskene de har kan være et uttrykk for at de er i en prosess der de lærer å tenke for å snakke på nytt når det gjelder definitthet. (Nordanger 2009: 118)

Når det gjelder tilegnelse av bestemthet, er det funnet bevis på at: «the prenominal definiteness marker found in modified structures is acquired much later than the suffixal definite article in Norwegian» (Anderssen 2007).

I sin artikkel under tittel Topic continuity in L2 English article use (2002) har Scott Jarvis undersøkt om finsk- og svenskspråklige engelskinnlærere skiller mellom seks diskursforhold som er en sammenkobling av to ulike diskursuniverser som inneholder ulike referentdimensjoner: (a) topic vs. Comment, og (b) new, continuous, and reintroduced NP referents (Jarvis 2002: 388). Videre har Jarvis undersøkt hvordan og til hvilken grad innlærerne bruker artikler for å differensiere de ulike diskursforholdene. Resultatet Jarvis har fătt av sin studie gir støtte til transferhypotesen:

The quantitative results of the study cast some doubt on learners' sensitivity to the topic-comment distinction and also suggest that learners' tendency to mark distinctions between new, continuous, and reintroduced NP referents is influenced by the prominence of such distinctions in the L1. (Jarvis 2002: 387)

Studier på tilegnelse av bestemthetskategorien viser altså det å lære seg denne kategorien er korrelert med innlærerens morsmål. Definitthet er en konseptuell kategori som krever reorganisering av det kognitive systemet hos innlæreren før den kan tilegnes, og brukes grammatisk korrekt.

\subsubsection{Tilegnelse av adjektivets semantikk}

Bente Ailin Svendsen skrev i 1998 en artikkel basert på sin masteroppgave i norsk som andrespråk der hun undersøkte 
adjektivtilegnelse hos voksne innlærere med norsk som andrespråk. Hennes studie dreier seg om tilegnelse av ordforrådet, og hun har undersøkt om høyfrekvente adjektiver læres før de lavfrekvente, og resultatet hun har fått fra studien er at adjektivets frekvens påvirker tilegnelsen når den er kombinert med (og underordnet) semantisk typologi. Svendsen 1998 har gitt belegg for at det $\mathrm{i}$ hver av de semantiske typene hun har undersøkt (inndelingen av adjektiver i semantiske typer har hun hentet fra Dixon (1982) som deler adjektiver i følgende semantiske typer: Dimensjon, Fysisk egenskap, Farge, Menneskelig tilbøyelighet, Alder, Vurdering og adjektiver som uttrykker Kvantitet), kan finnes noen få høyfrekvente adjektiver som er lært før de andre (mindre frekvente) adjektivene. Svendsen har imidlertid ikke sett på hvilken rekkefølge de semantiske typene er tilegnet i. Heller ikke har hun sett på tverrspråklig innflytelse som muligens kunne finne sted i innlærernes produksjon siden informantene hennes hadde flere ulike morsmålsbakgrunn: urdu, vietnamesisk, kurdisk, arabisk, somalisk og fransk (totalantall informanter var 42). Et annet forbehold gjelder hennes metode, der hun betrakter for 'tilegnet' adjektiver brukt i både riktig semantisk betydning og i riktig bøyningsform. Alt i alt er Svendsens studie et videre belegg for at adjektivers frekvens spiller en rolle i tilegnelsesprosessen.

\subsubsection{Oppsummering}

I dette underkapittelet har jeg kort presentert ulike studier om tilegnelsen av kongruens $i$ et andrespråk. Jeg har prøvd å vise de studiene som gjelder kongruens i skandinaviske språk, men også andre S2 har blitt presentert. I tillegg refererte jeg til et par studier om genus- og bestemthetstilegnelse siden de to også kan ha påvirkning på tilegnelsen av kongruens i norsk. Studien om tilegnelsen av semantikken til de norske adjektivene viser i sin tur at både frekvens og semantisk typologi er viktige i læringsprosessen. Et bilde som kommer til syne på grunnlag 
av denne presentasjonen er at kongruenstilegnelse er en sammensatt prosess der både prosesseringsprinsipper (samt læringsrekkefølge) og transfer spiller en viktig rolle.

\subsection{Hypoteser og forskningsspørsmål}

På basis av teoriene framstilt tidligere i dette kapittelet og kontrastiv analyse av adjektivisk kongruensbøyning i norsk og polsk (som blir presentert i det etterfølgende kapittelet), har jeg laget hypoteser og stilt forskningsspørsmål angående polskspråklige norskinnlæreres tilegnelse av adjektivisk samsvarsbøyning i norsk som S2.

For det første skal jeg gjennom analysen finne svar på følgende spørsmål:

1) Hvilke typer feil i samsvarsbøyning er gjort, det vil si hvilke endelser er blandet sammen? Hva kan være årsaken til feilene?

2) Hva er den grammatiske konteksten til feilene? Er det en tendens til at feilene oftere forekommer ved ubestemte / bestemte former, entall / flertall, i attributiv / predikativ stilling? Hva er konteksten til korrekt bruk av den adjektiviske samsvarsbøyningen? Finnes det noen samsvarsbøyningskategorier som innlærerne performerer oftere ukorrekt enn korrekt i?

3) Hvilke egenskaper har de adjektivene som oftest er bøyd ukorrekt? Hører de til det regelmessige paradigmet eller viser de noen avvik fra paradigmet?

Med utgangspunkt i artikkelen til Glahn med flere (2001) som har undersøkt Pienemanns prosessabilitetsteori i adjektivisk samsvarsbøyning i skandinaviske språk, kan man forvente at innlærere gjør flere feil i predikativ stilling enn i attributiv stilling. Videre, i forbindelse med studien til Glahn med flere (2001), Ragnhildstveit (under arbeid) og Nordanger (2009) er det rimelig å anta at det ikke blir gjort så mange feil i 
numerus som $\mathrm{i}$ genus og bestemthet ettersom numeruskategorien brukes på konseptuelt grunnlag (som innlærerne allerede står til rådighet med fordi de polskspråklige innlærere er kjent med entalls- / flertallskonseptet i morsmålet sitt), mens genuskategorien må læres i norsk og bestemthet er et konsept som først må tilegnes (fordi det er helt nytt for de polskspråklige innlærerne) før det kan brukes i adjektivbøyning korrekt. I tilfellet genus- og bestemthetskategorien er det en fare at disse to kategoriene tilegnes senere enn adjektivisk samsvarsbøyning som sådan, noe som igjen kan påvirke innlærernes performanse i adjektivisk samsvarsbøyning. Slik sett er en full tilegnelse av adjektivisk samsvarsbøyning i norsk som S2 ikke mulig før man har tilegnet seg genus- og bestemthetskategorien.

Også noen andre grammatiske kontekster kan påvirke de polskspråklige norskinnlærernes performanse i norsk adjektivisk samsvarsbøyning negativt. Her vil jeg tenkte meg tilfeller når kongruens ikke finner sted på grunn av noen spesielle grammatiske forhold som forekommer i noen typer fraser. For eksempel mangler kongruens i genitivfraser (da får adjektivet endelsen $-e$, uavhengig av deres kjønn og tall) og superlativfraser (da får adjektivet ikke noen endelse, uavhengig av deres kjønn og tall).

Det regelmessige paradigmet kan tenkes å bli tilegnet før det uregelmessige. Likevel kan også en motsatt situasjon antas å være sannsynlig siden det kan forekommet en U-formet læring (beskrevet i Sharwood Smith \& Kellerman 1989) i dette tilfellet.

Videre skal jeg undersøke sosiale faktorers påvirkning på de polskspråklige norskinnlærernes performanse i norsk adjektivisk samsvarsbøyning. Jeg skal teste hypoteser om at følgende seks faktorer påvirker deres performansen positivt:

1. Høyere generelle norskkunnskaper,

2. Lavere alder,

3. Høyere utdanning,

4. Flere kurstimer i norsk, 
5. Lengre opphold i Norge,

6. Bedre kunnskaper i engelsk som S3.

Til slutt skal jeg undersøke hvilken påvirkning på tilegnelse av norsk adjektivkongruens har det å ha polsk som morsmål. I transferanalysen skal jeg sammenligne performansen til de polskspråklige norskinnlærerne med performansen til de engelsk- og tyskspråklige norskinnlærerne. Fordi norsk og polsk er mest like når det gjelder adjektivisk samsvarsbøyning, engelsk er mest ulik norsk (og polsk), og tysk plasserer seg på et mellomnivå mellom norsk (og polsk) og engelsk (tysk er lik norsk (og polsk) i adjektivisk samsvarsbøyning $\mathrm{i}$ attributiv stilling, men ulik dem i predikativ stilling $)^{16}$, vil jeg stille følgende hypoteser om tverrspråklig innflytelse:

1. Ettersom polsk og norsk er mer like hverandre enn engelsk og norsk, vil de polskspråklige norskinnlærernes oppføre seg mer korrekt i norsk adjektivkongruens enn de engelskspråklige. Det forekommer altså positiv transfer fra S1 polsk hos de polskspråklige norskinnlærerne.

2. Ettersom engelsk og norsk er mindre like hverandre enn polsk og norsk, vil de engelskspråklige norskinnlærernes oppføre seg mindre korrekt i norsk adjektivkongruens enn de polskspråklige. Det forekommer altså negativ transfer fra S1 engelsk hos de engelskspråklige norskinnlærerne.

3. Ettersom tysk og norsk er like hverandre i attributiv stilling, og ulike hverandre i predikativ stilling, vil de tyskspråklige norskinnlærerne oppføre seg mer korrekt i norsk adjektivkongruens i attributiv stilling enn i predikativ stilling. Det forekommer altså positiv transfer fra S1 tysk i attributiv stilling, og negativ transfer fra $\mathrm{S} 1$ tysk i predikativ stilling hos de tyskspråklige norskinnlærerne. Siden det tross alt finnes

${ }^{16}$ En bredere beskrivelse av adjektivisk kongruens i norsk, polsk, engelsk og tysk befinner seg i kapittel 3. 
adjektivkongruens i tysk, kan man forvente at de tyskspråklige norskinnlærere vil oppføre seg mer korrekt i samsvarsbøyning av norske adjektiver enn de engelskspråklige som ikke er kjent med adjektivkongruensfenomenet fra morsmålet sitt. Det forekommer altså positiv transfer fra S1 tysk hos de tyskspråklige norskinnlærerne (iallfall i sammenligning med de engelskspråklige norskinnlærerne).

Alle disse hypotesene vil bli testet i Analysekapittelet. Først vil jeg imidlertid presentere de viktigste begrepene brukt i denne avhandlingen og egenskapene ved de norske adjektivene (kapittel 3), og deretter datamaterialet som metoder brukt i analysen (kapittel 4). 


\section{Adjektiver og kongruens 3.1 Adjektivbegrepet}

Siden adjektivbegrepet står sentralt i denne drøftelsen, er det vesentlig å redegjøre for det utdypende. I dette underkapittelet vil jeg først drøfte hvorvidt denne ordklassen er universell, og diskutere adjektivets plass blant de andre ordklassene, både fra det typologiske og norske perspektivet. Så vil jeg diskutere denne ordklassen i lys av norske, polske, engelske og tyske grammatikker, og omtale hvordan den blir definert der. Til slutt vil jeg presentere min definisjon av det norske adjektivet som bygger på prototypiske og perifere betydninger. I tillegg vil jeg gjøre greie for hvordan jeg vil bruke adjektivbegrepet $\mathrm{i}$ avhandlingen.

\subsubsection{Adjektiv som en av ordklassene}

Verdens språk er ulike på mange måter, også når det gjelder ordklasser - deres antall og inventar. Riktignok er de noe som finnes i alle språk, men språkene varierer i mengde og type ordklasser (Anward 2003: 3). Et eksempel på en ordklasse som finnes i noen språk (bl.a. vietnamesisk, japansk, kinesisk), og ikke finnes $\mathrm{i}$ andre (bl.a. norsk, polsk, engelsk, tysk), er klassifikatorer (Gil 2013). Selv om de er obligatoriske i en del mål, kan de andre godt klare seg uten dem. Å finne noen universelle ordklasser, som finnes på tvers av språk, er ingen lett oppgave, men «de fleste språkforskere [tror] at alle språk i det minste skiller mellom en ordklasse som kan kalles verb, og en som kan kalles substantiv» (Schachter og Shopen 2007 referert i: Næss 2011: 77), og likevel «[er] alle selv ikke dette enige i» (Næss, ibid.). Adjektiver er iallfall ikke den ordklassen forskerne nevner som universell og eksisterende i alle språk. Mens adjektiver er vanlige i europeiske språk, blant annet germanske og slaviske, er det også eksempler på språk som ikke har adjektiver i det hele tatt. I så fall danner «adjektiviske ord» en felles kategori med enten verb eller substantiver, eller begge 
deler. Basert på slike observasjoner innførte Bhat (1994) en typologi som deler verdens språk inn i fire grupper: De som har adjektiver som en egen ordklasse (f.eks. dravidiske språk), de hvor adjektiver danner en felleskategori med substantiver (f.eks. indoariske språk), de hvor adjektiver danner en felleskategori med verb (f.eks. tibetoburmanske språk), og de hvor adjektiver danner en felleskategori både med substantiver og med verb (f.eks. munda-språk). Riktignok kan adjektivet (i de språkene der det fungerer som en separat ordklasse) beskrives prototypisk som en ordklasse som uttrykker to sammenbundne parametrer: den semantiske - å uttrykke egenskaper og den pragmatiske - å modifisere (Croft 1991: 93), men variasjonen som finnes blant verdens språk giør det for det første vanskelig, og for det andre egentlig unødvendig å skrive generelt om adjektiver i denne oppgaven. Isteden vil jeg bare konsentrere meg om de språkene jeg skal bruke i analysen, det vil si norsk, polsk, engelsk og tysk, og ikke andre, for selv om «Prototypen i en språklig kategori [ofte] er den samme på tvers av språk (...), [varierer] grensa for medlemskap - hvor likt noe må være prototypen for at det skal høre til i kategorien - mellom språk» (Næss 2011: 51).

Hva man kaller for adjektiv, avhenger av ordklasseinndelingen man bruker, og den avhenger i sin tur av kriterier man bruker i inndelingen. Ettersom kriteriene velges arbitrært i tråd med sine formål (f.eks. setter Norsk referansegrammatikk (1997) og Rønhovd (1993) morfologiske kriterier først, mens Hagen (1998) setter opp syntaktiske kriterier først), kan det ikke finnes bare én riktig, alminnelig gjeldende inndeling. Ordklasseinndelingen er et $\mathrm{i}$ stor grad omstridt tema fordi den både er avhengig av ens behov og syn på språk og av det hva og hvordan man analyserer, derfor kalte Næss (2011: 67) ordklasser for «analyseverktøy». Valget av definisjonen av adjektivet jeg vil bruke $i$ avhandlingen, er av den grunn en følge av dens tema, men før jeg kommer til min definisjon av begrepet, skal jeg først vise hvordan adjektivene er definert i norske grammatikker, og sammenligne definisjonene med de som er gjeldene i polsk, 
engelsk og tysk. I tillegg skal det vises hvordan de ulike grammatikkene takler grensetilfeller, først og fremst partisipper, som i mange språk blir klassifisert som en egen ordklasse, for eksempel i latin (Rønhovd 1993: 80). I beskrivelsen av adjektivdefinisjonene er jeg nødt til å bruke andre ordklassenavn i deres «tradisjonelle» og «intuitive» skoleforstand slik at jeg best mulig kan konsentrere meg om adjektivkategorien.

\subsubsection{Adjektiver i norske grammatikker}

Når det gjelder den norske ordklasseinndelingen, har det flere ganger skjedd endringer i den. I sin grammatikk minner Berulfsen (1967: 10) om at man først skilte mellom åtte ordklasser i norsk: nomen, pronomen, verbum, adverbium, participium, conjunctio, præpositio og interjectio slik det var vanlig $i$ den latinske tradisjonen. Denne klassifiseringen manglet adjektiver som en separat ordklasse fordi de var inkludert i nomenklassen, det vil si «nomen var samnavn på substantiv og adjektiv, som opprinnelig i de indoeuropeiske språk ble bøyd ens» (Berulfsen 1967: 11). Inndelingen inneholdt heller ikke artikler og tallord. Senere oppstod det den «tradisjonelle» norske inndelingen hvor man opererte med ti klasser: substantiv, adjektiv, verb, adverb, pronomen, preposisjoner, interjeksjoner, konjunksjoner, tallord og artikler (Rønhovd 1993: 81). Denne klassifiseringen viste seg likevel å være utilstrekkelig til det norske språket, og dessuten ble den kritisert for sin inkonsekvens, for «bruken av de ulike inndelingskriteriene er temmelig tilfeldig og ikke skjer ut fra faste prinsipper» (Kulbrandstad 2012: 108). Da Norsk referansegrammatikk (fork. NRG) ble utgitt i 1997, innførte den en ny ordklasseinndeling som siden har vært gjeldende slik at den blant annet blir brukt i undervisningen i skolen (Kulbrandstad 2012: 109). NRG (1997: 20) skiller altså mellom ti ulike ordklasser i norsk: substantiv, verb, adjektiv, pronomen, determinativ, preposisjon, adverb, konjunksjon, subjunksjon, interjeksjon. 
Som sagt ovenfor, avhenger en ordklasseinndeling av kriteriehierarkiet man velger. Både NRG (1997), Rønhovd (1993) og Kulbrandstad (2012) setter morfologiske kriterier ved ordene høyest, mens Hagen (1998) prioriterer de syntaktiske kriteriene. Rønhovd (1993: 85) betegner adjektiver som «bøygde leksem» ved siden av verb, substantiver, pronomener og determinativer, og den samme beskrivelsen kan man finne både i NRG (1997) og i Kulbrandstad (2012). Som en ordklasse med bøyning blir adjektiver karakterisert av gradbøyning, noe NRG (1997) formulerer slik: «Adjektiver er først og fremst ord som kan gradbøyes» (NRG 1997: 22). Videre skriver de: «Mange adjektiver blir imidlertid ikke gradbøyd (dvs. ved hjelp av endelse), men blir likevel regnet med til adjektivene siden de kan uttrykke de samme forholdene ved foranstilling av mer|meir og mest» (ibid.). Til slutt blir det sagt at: «Også en del andre ord, som ikke kan gradbøyes fordi de egenskapene de betegner, ikke kan graderes, regnes til adjektivene» (ibid.). Ved første øyekast kan deres definisjon virke selvmotsigende, men i virkeligheten er den en prototypetdefinisjon som ikke er uttrykt direkte. Rønhovd (op. cit.) er enig med NRG i at gradbøyning er adjektivets kjennetegn, og hevder at «Dette eigentleg [er] eit tilstrekkeleg definisjonskjenneteikn, men vi kan også ta med at mange adjektiv kan ha adverbialbøying og kongruensbøying». NRG nevner også de to andre typene bøyning (NRG 1997: 22, 345). Det bør forresten observeres at gradbøyningen er en typisk adjektivisk kategori bare i tilfellet når man betrakter ordene som lavt, godt, fint som bøyde adjektiver og ikke som adverb laget av adjektiver med avledning, for dersom det sistnevnte er tilfellet, må man fastslå at også adverb har gradbøyning, og ikke bare adjektiver, og dette er noe som Kulbrandstad (2012: 116) påstår. Hans definisjon avviker fra NRG og Rønhovds når det gjelder måten han takler adverb på. Han omtaler forskjellene eksplisitt: «I referansegrammatikken blir alle ord som kan gradbøyes, regnet som adjektiv. Det gjelder blant annet fort, ofte og mye.» (Kulbrandstad 2012: 173), og: «I Norsk referansegrammatikk framstilles adverb som en ordklasse uten bøying. 
Bøyelige ord som tradisjonelt regnes som adverb, føres til adjektivklassen» (ibid.: 111). Adverb i Kulbrandstad (2012) kan gradbøyes selv om det ikke er deres typiske egenskap, og de er beskrevet av ham fra det syntaktiske synspunktet som innebærer å «modifisere innholdet i setningen eller setningsdelen» (ibid.: 173). Rønhovd (1993) problematiserer også ord som: ofte, lenge og lignende fordi de kan gradbøyes selv om de tradisjonelt blir betraktet som adverb. Men både Rønhovd og NRG er konsekvente i å anse gradbøyning som kun adjektivets kjennetegn, og derfor forblir ofte, lenge og lignende adjektiver i deres definisjoner.

Kulbrandstads (2012) definisjon av adjektivet er forskjellig fra de to andre også på et annet punkt. Lingvisten vurderer å betrakte kasusbøying også som en kategori norske adjektiver kan bøyes i. Verken NRG (1997) eller Rønhovd (1993) har uttrykt det samme synspunktet (de har rett og slett ikke uttalt seg på dette temaet), som er ganske uvanlig i den norske lingvistikken, for selv om s-genitiven kan betraktes som en type kasusbøying, blir det generelt sett påstått at det ikke er kasusbøying i norsk.

Adjektivets syntaktiske funksjoner kommer etter de morfologiske i de tre tilnærmingene, mens Hagen (1998) omtaler dem først fordi han påstår at ordenes morfologiske egenskaper bare er derivert fra betydningen og funksjonen, og på dette punktet er han enig med Bhat (1994: 18). Han nevner selvfølgelig de to typene bøyning de andre lingvistene skriver om: «mange adjektiver, men ikke alle, [har] visse morfologiske egenskaper, de har komparasjonsbøyning og kongruensbøyning» (Hagen 1998: 111), men hans definisjon av adjektivet er rent syntaktisk, og den framhever ordklassens attributive funksjon: «Adjektiver er ord som kan stå som beskrivende adledd til et kjernesubstantiv $i$ en substantivfrase eller som kjerne $i$ en slik adleddsfrase» (Hagen 1998: 111), og setter den over den predikative: «I norsk kan de fleste adjektiver i tillegg også opptre predikativt» (ibid.). Det kan derfor deduseres at attributtfunksjonen i adjektivet er primær (eller med andre ord 
mer prototypisk) i forhold til predikativfunksjon, ifølge lingvisten, og at den danner en premiss for å kalle et ord adjektiv. Predikativfunksjonen er altså av sekundær betydning, og er en slags bifunksjon som adjektiver kan ha, men som ikke er uunnværlig. Et slik perspektiv fører til at noen ord, som tradisjonelt betraktes som adjektiver, blir vanskelige (om ikke umulige) å klassifisere som sådan ettersom de bare kan fungere som predikativer, og ikke som attributter i setningen. Herunder hører for eksempel: Jeg er kvitt ham. (vs. *en kvitt mann), Huset er verdt en million (vs. *et verdt hus $)^{17}$. NRG (1997) og Kulbrandstad (2012) graderer ikke syntaktiske funksjoner, men bare nevner dem. I NRG sies det at «adjektivet er kjerne i adjektivfrasen» (NRG 1997: 22, 345) som i sin tur «er oftest predikativ i setningen eller adledd i en substantivfrase» (ibid.), og Kulbrandstad (2012) er i grunnen enig med denne karakteristikken. Han (Kulbrandstad 2012: 117) nevner at adjektiver har to hovedfunksjoner i setningen: Den attributive (når adjektivet er underordnet substantivet $\mathrm{i} \mathrm{NP}$ ) og predikative funksjonen (når adjektivet er et selvstendig ledd i setningen). Dessuten kan adjektivet utgjøre adverbialer (både setningsadverbialer og predikatsadverbialer) dersom det står i intetkjønn (Åfarli \& Sakshaug 2006: 50, 52). NRG angir i tillegg en fjerde funksjon ved adjektiver: adledd til et annet adjektiv (NRG 1997: 393), omtalt av Hagen (1998: 353) som gradsadverbial. Når det gjelder Rønhovd (1993), nevner han bare attributtfunksjonen ved adjektivet eksplisitt: «dei fleste kan stå framfor eit substantiv» (Rønhovd 1993: 86), men indirekte skriver han også om den predikative funksjonen: «Nokre adjektiv er spesielle i det at dei berre kan opptre attributivt eller predikativt» (ibid.), og det kan bety at han tar den for gitt.

Adjektivets betydning omtales sist både i NRG (1997), Rønhovd (1993) og Kulbrandstad (2012), men Hagen (1998) setter den på samme linje med attributivfunksjonen. Sammen med den danner semantikken et grunnlag for at et ord regnes som et adjektiv. Ifølge det semantiske kriteriet er adjektiver

${ }^{17}$ Eksemplene hentet fra $N R G$ (1997: 393). 
«leksikalske ord som typisk betegner egenskaper og tilstander ved individer, gjenstander osv.» NRG (1997: 22), og Hagen (1998: 111) beskriver her prototypiske adjektiver: «Prototypisk er adjektiver ord som uttrykker egenskaper ved substantivfrasens referent, og kalles derfor 'egenskapsord'». Heller ikke beskrivelsen i Golden med flere skiller seg fra de to på dette området, der det sies at: "[Adjektivene] forteller noe om egenskaper ved personer og ting (...). De gir også nærmere beskrivelser av tilstander, handlinger og egenskaper» (Golden, Mac Donald \& Ryen 2014: 19).

For å oppsummere drøftelsen ovenfor, ifølge NRG (1997), Kulbrandstad (2012) og Rønhovd (1993) er adjektiver de ordene som kan gradbøyes (selv om Kulbrandstad (2012) tillater også adverb å ha gradbøyning), mens ifølge Hagen (1998) kan vi kalle et ord for adjektiv dersom ordet betegner en egenskap og kan stå attributivt i setningen. Selv om de definisjonene ser ulike ut, refererer de i grunnen til den samme prototypen. Riktignok er ikke definisjonene strikte prototypiske (begrepet prototypisk blir ikke brukt i dem), men det finnes flere antydninger til prototypiske eller typiske karakteristikker, blant anent hos Hagen (1998) og Kulbrandstad (2012). Imidlertid er disse indikasjonene oftest indirekte og inkonsekvente, slik at definisjonene ligner mest på den aristoteliske klassifiseringsmåten som vil sette klare og tydelige grenser mellom kategoriene (Lakoff 1987: 6), blant annet ordklassene, og som betrakter mindre typiske eksempler mer som unntak fra regelen enn en del av regelen, noe som prototypeteorier gjør. Men siden definisjonene jeg har referert til, beskriver den samme prototypen, og er i verste fall forskjellige $\mathrm{i}$ begrensningen av adjektivklassen, er det verdt å ta en kikk på hvordan grammatikerne tegner grensen for adjektivet, og hvilke ord klassifiserer de som perifere adjektiver, og hvilke som andre ordklasser. Det er fem viktigste grupper ord som enten kan klassifiseres som adjektiver eller som medlemmer av andre ordklasser. Disse gruppene er: noen substantiver, noen adverb, partisipper, ordenstall og possessiver (hvis de altså ikke blir klassifisert som 
adjektiver). Jeg skal nå skissere grovt hvordan de er behandlet $\mathrm{i}$ de norske grammatikkene. Jeg vil først bare merke at ikke alle grammatikkene omtalt her problematiserer alle de potensielt perifere adjektivene.

For eksempel er partisipper ikke tatt til drøfting av Kulbrandstad (2012). De øvrige lingvistene har derimot gitt sine argumenter for enten å klassifisere partisippene som adjektiver (Hagen 1998) eller som verb (Rønhovd 1993), eller dels som adjektiver, dels som verb - avhengig av hvilken funksjon de har i setningen (NRG 1997). I Hagens (1998) tilnærming er partisippene tatt inn $i$ adjektivklassen fordi de betegner egenskaper og kan stå attributivt til substantiver. Partisippene er der beskrevet som de to viktigste gruppene av adjektivavledninger (presens og perfektum partisipp er betraktet separat), ved siden av ordenstall og «andre avledninger» (Hagen 1998: 122). Hagen nekter imidlertid ikke at partisippene «i tillegg [har] rent verbale funksjoner» (ibid.: 123), og av den grunn deler han dem i to grupper: de som «opptrer som adjektiver» og de som ikke gjør det, det vil si de som opptrer som verb (ibid.). Rønhovd (1993: 86) i sin tur hevder at «den verbale funksjonen desse formene kan ha», er avgjørende, og derfor betrakter han dem som bøyningsformer av verb selv om han også gir gode argumenter for å regne dem som adjektiviske derivasjonsformer fra verb, og argumentene hans er av både syntaktisk og morfologisk slag: Partisipper kan syntaktisk fungere på samme måte som adjektiver, og i tillegg får de oftest samme morfologiske kategorier som adjektiver. Likevel prioriterer han deres verbale funksjon. I NRG betraktes partisipper $\mathrm{i}$ attributtfunksjonen som adjektiver ettersom de kongruensbøyes, mens de i predikativfunksjonen betraktes som verb, iallfall på bokmål, ettersom de ikke kan kongruensbøyes. Imidlertid finnes det en gruppe partisipper som blir kongruensbøyd i predikativ stilling (f.eks. dere er velkomne, de var som besatte o.a. ${ }^{18}$ ), og slike partisipper klassifiserer NRG (1997) som adjektiver, for de kan kongruensbøyes (NRG 1997: 345).

${ }^{18}$ Eksemplene hentet fra $N R G$. 
I NRG er presens partisipper betraktet som adjektiver laget av verb med avledning (NRG 1997: 118-119) til tross for at de verken kan gradbøyes eller kongruensbøyes. Deres syntaktiske egenskaper (de kan stå som adledd til substantiver og som predikativer) er i dette tilfellet avgjørende.

En annen gruppe ord som kan betraktes som perifere adjektiver er ord som lavt, godt, fint som kan fungere som adverbialer. Både NRG (1997: 393), Hagen (1998: 345) og Rønhovd (1993: 86) kategoriserer dem som bøyde adjektivformer. Også ordenstall tar Hagen (1998: 122) inn i adjektivklassen, og det samme gjør NRG (1997: 27), Kulbrandstad (2012: 172) og Rønhovd (1993: 86). Enda et grenseområdet utgjør ord som for eksempel: rødt, smått, nytt. Til tross for at de er nøytrumsformer av adjektivene: rød, små, brukt, ny, kan de stå som nominaler (bl.a. Bokmålsordboka definerer dem som substantiver). Likevel betrakter NRG (1997: 393) disse ordene som adjektiver, og begrunner det slik: «Betydningen er gjerne generell: Rødt er stilig = 'røde ting er stilige', 'det som er rødt, er stilig'». Ordene er i så fall adjektiver i ellipsekonstruksjoner hvor substantivet er utelatt. En annen måte å se på disse ordene på er framstilt i Kulbrandstad (2012: 156). Han kaller disse konstruksjonene: «substantivisk bruk av adjektivet», og denne framstillingen nærmer ham Bhat (1994: 119) som også hevder at de opprinnelige adjektivene forblir adjektiver i slike tilfeller, men at de er rekategorisert til substantiver, det vil si får funksjonen fra substantivet. Den siste gruppen ord som kan settes inn i to forskjellige grupper, avhengig av kriteriene man velger, er possessiver. Riktignok kan de ikke gradbøyes, men de har kongruensbøyning, og kan stå både $\mathrm{i}$ attributiv og $\mathrm{i}$ predikativ stilling. Imidlertid kategoriserer Hagen (1998: 208), Kulbrandstad (2012: 164), Rønhovd (1993: 58) og NRG (1997: 28) dem som determinativer.

En generell konklusjon, som kan trekkes fra framstillingen ovenfor, er at de norske forskerne refererer til det samme adjektivet $\mathrm{i}$ sine definisjoner, både $\mathrm{i}$ prototypisk og perifer betydning (det eneste unntaket er partisipper), til tross for at de 
formulerer det ulikt. Dette er ikke tilfellet i polsk hvor definisjonene i større grad påvirker perifere områder som vurderes å tas inn i adjektivklassen. Nedenfor presenterer jeg de viktigste definisjonene av polske adjektiver.

\subsubsection{Adjektiver i polske grammatikker}

Som i de norske grammatikkene, kommer man også i de polske ut fra ulike sett kriterier når man definerer ordklasser. Noen grammatikere tar utgangspunkt i morfologien, andre i syntaksen, og atter andre i semantikken (noe som ingen norsk grammatiker gjør). For eksempel ligner Strutyńskis (2009: 179) definisjon av adjektiv Hagens (1998) definisjon i den forstand at han baserer den på syntaktiske kriterier, og hevder at adjektiver har som sin primære funksjon å være attributt $\mathrm{i}$ setningen. Likevel er de sekundære funksjonene han nevner, annerledes enn i Hagen (1998). Han angir nemlig predikativ-, subjekts- og objektsfunksjonen ved adjektivet, og de to siste er særegne i forhold til norsk. Doroszewskis (1963: 201) definisjon er også syntaktisk, men i motsetning til Strutyński nevner han ikke subjekts- og objektsfunksjoner ved adjektivet. Dessuten mener han at adjektivets funksjon i setningen er å stå som både attributt og predikativ. Begge de to lingvistene presenterer i tillegg en omfattende morfologisk klassifikasjon av adjektiver.

Saloni og Świdziński (1998: 102) bruker morfologiske kriterier i ordklasseinndelingen, og derfor definerer de adjektiver som ord som bøyes i kasus, genus og numerus. Resultatet av en slik definisjon er at også tallord, adjektivpartisipper, possessivpronomener og påpekende pronomener kategoriseres som adjektiver.

Milewski (1965: 118) og Klemensiewicz (2001: 54) definerer adjektiver fra et semantisk perspektiv, og ifølge dem er adjektiver ord som gir navn på kvaliteter hos ting, mennesker, og som stundom kan benevne ting, mennesker og så videre. 
I Nagórko (2007: 159) nevnes det egenskaper ved adjektiver i stedet for å definere dem. Ordklassen er beskrevet med at den har genus-, numerus- og kasusbøying samt at den kan fungere både som attributter og som predikativer i setningen. Nagórko stiller seg skeptisk til å betrakte gradbøyning som en typisk egenskap ved adjektiver siden mange adjektiver ikke kan bøyes i grad (Nagórko 2007: 161).

En grov sammenligning av norske og polske definisjoner av adjektivet viser ikke større ulikheter. Adjektiver viser til egenskaper ved mennesker, dyr, ting og så videre, har bøyning (både i polske og norsk grammatikker nevnes det kongruens- og gradbøyning (selv om den sistnevnte vurderes å ikke være typisk adjektivkarakteriserende)) og fungerer som attributter og predikativer i setningen. Likevel er det noen forskjeller i beskrivelsene. Både norske og polske adjektiver kongruensbøyes i tre kategorier: tall og genus er felles for begge språkene, mens den tredje kategorien utgjør bestemthet i norsk og kasus i polsk (som for øvrig er diskutert av Kulbrandstad (2012) for å muligens være den fjerde kategorien norske adjektiver kan kongruensbøyes i). Når det gjelder adjektivets funksjoner i setningen, finnes det også noen ulikheter mellom norsk og polsk. I norske grammatikker nevnes det at adjektiver kan stå som adverbialer og som adledd i adjektivfrasen (i polske grammatikker tilhører disse funksjonene adverb), mens i polske grammatikker blir det nevnt subjekts- og objektsfunksjoner ved adjektivet (i Strutyński 2009). De er imidlertid oftest betraktet som ellipsekonstruksjoner med utelatt substantiv, som er kjernen i nominativfrasen. Til tross for disse forskjellene i definisjonene, kan det konstateres at det norske og polske prototypiske adjektivet egentlig er likt i begge språkene. Ulikhetene viser kun at grenser for perifere betydninger går noen ganger annerledes i hvert av dem. 


\subsubsection{Adjektiver i engelske grammatikker}

I denne og den neste seksjonen blir det skissert hvordan adjektiver omtales i de engelske og tyske grammatikkene ettersom de to språkene vil også blir analysert i denne oppgaven, men i mindre grad enn norsk og polsk. I de engelske grammatikkene er adjektiver stort sett definert på basis av syntaktiske kriterier. Både Carter og McCarthy (2006: 445), Greenbaum og Quirk (1990: 129) og Leech og Svartvik (2003: 172) nevner attributiv- og predikativfunksjonen som det viktigste og i grunnen avgjørende kriteriet for å klassifisere et ord i denne ordklassen. Også Sinclair (1992: 62) er av samme mening og formulerer det slik: «Adjectives can be used as modifiers of a noun or as complements of a link verb». Samtidig påpekes det at noen adjektiver kun kan fungere attributivt eller predikativt. Greenbaum og Quirk (op. cit.) skiller imidlertid mellom sentrale og perifere medlemmer av adjektivklassen, og for de prototypiske adjektivene kaller de de adjektivene som kan stå $i$ begge posisjonene, mens de som kan stå i bare en av posisjonene blir kalt perifere av dem. Bortsett fra attributiv- og predikativfunksjonen nevnes det også en til funksjon av adjektivet - postpositiv stilling, som kan betraktes som en undertype av predikativstilling (Sinclair 1992: 75, Greenbaum \& Quirk 1990: 136).

Det omtales ofte to andre grammatiske egenskaper ved adjektiver i de engelske framstillingene: adjektivets mulighet til å ta en premodifiserende gradsadverbial (eng. intensifier), for eksempel very, og til å bli gradbøyd, enten morfologisk, ved hjelp av endelsene: -er og -est, eller perifrastisk, ved hjelp av premodifikasjoner: more og most. De to egenskapene sies likevel å være begrenset til bare en del adjektiver, og ikke kan betraktes som identifiserende for denne ordklassen (Greenbaum \& Quirk 1990: 129). Ifølge blant anet Carter og McCarthy (2006: 445), Sinclair (1992: 289) og (Greenbaum \& Quirk 1990: 129) kan også adverb ha disse to egenskapene. 
Når det gjelder det semantiske aspektet ved adjektivet, sier Carter og McCarthy (2006: 438) at: «They describe the features of persons or things denoted by nouns or pronouns»». Morfologisk sett, har de ingen bøyning (Sinclair 1992: 63) (bortsett fra gradbøyningen, som likevel ikke skiller dem fra adverbklassen (Greenbaum \& Quirk 1990: 129), og de kan ikke automatisk identifiseres av formen de har, selv om det finnes noen suffikser som bare forekommer ved adjektiver, for eksempel -able, -ful, -ish og flere (Carter \& McCarthy 2006: 438). Det kan derfor sies at det engelske og norske adjektivet er ganske lik hverandre, unntatt morfologiske egenskaper, som i tilfellet engelsk adjektiv er svært begrenset.

\subsubsection{Adjektiver i tyske grammatikker}

Det tyske adjektivet blir, slik som det engelske, definert på grunnlag av sine grammatiske egenskaper, og ikke semantiske, men i motsetning til de engelske framstillingene, spiller morfologi en mye større rolle i definisjonen her, noe som er motivert av språkets karakter. I Duden (2005: 345) nevnes det for eksempel bøyning på første plass i karakteristikken av denne ordklassen. Adjektivet bøyes dermed i samsvar med substantivet det står til, i tre kategorier: kasus, genus og tall (ibid.). I tillegg skilles det mellom sterk og svak bøyning, det vil si bøyning etter henholdsvis ubestemt og bestemt artikkel. Foruten sies det i Duden (op. cit.) at de fleste adjektivene også har komparasjonsbøyning. Helbig og Buscha (2001: 281) oppgir fire egenskaper ved adjektiver, hvorav det syntaktiske (muligheten til å brukes attributivt og / eller predikativt) er regnet som viktigere enn de syntaktiske (deklinasjon i attributiv stilling og gradbøyning ved en del adjektiver), og det morfosyntaktiske (muligheten til å være sekundær valensbærer), som snarere tjener som et klassifiseringsgrunnlag enn som et særtrekk ved denne ordklassen (Helbig og Buscha 2001: 282). Mens Helbig og Buscha (2001: 281) tillater muligheten til at noen adjektiver kun kan stå attributivt eller predikativt, hevder 
Engel (1996: 558) at attributiv funksjon er mulig ved alle adjektiver. Han definerer adjektivet distribusjonelt: "Adjektive sind Wörter ohne konstantes Genus, die zwischen Determinativ und Nomen stehen können» (Engel 1996: 556), og en lignende distribusjonell definisjon befinner seg i Duden (2005: 345).

Blant adjektivets syntaktiske funksjoner nevner Duden (2005: 347) også adverbialfunksjonen ettersom det formelt sett ikke er noen grunn til å fastslå at det forekommer ordklasseskifte i adverbialt bruk av adjektivet (op. cit.: 360), noe Engel (1996: 558) er enig om. Helbig og Buscha (2001: 280) hevder imidlertid det motsatte, nemlig at det forekommer ordklasseskifte når adjektiver blir brukt adverbialt, og de klassifiserer dem i denne situasjonen som adverb. Duden (2005: 354) nevner dessuten substantivisk bruk av adjektiver.

Semantisk sett skiller det tyske adjektivet seg ikke fra det norske, polske og engelske, og det sies at adjektiver blir brukt til å modifisere og kvalifisere andre elementer (Engel 1996: 556).

\subsubsection{En prototypedefinisjon av adjektivklassen i norsk}

I denne seksjonen vil det bli presentert en prototypedefinisjon av det norske adjektivet. Definisjonen baserer seg på de eksisterende definisjonene som er blitt referert til ovenfor, men konsentrerer seg også om forskjellen mellom de prototypiske og perifere ${ }^{19}$ betydningene, og fremhever dem. Her vil det dessuten bli redegjort for hvordan adjektivbegrepet vil bli brukt i dataanalysen i denne avhandlingen, det vil si at det skal vises her hvor grensen mellom adjektiver og ord fra andre ordklasser går. Bestemmelsene jeg har tatt og avgrensingene jeg har innført når det gjelder adjektivbegrepet er motivert av oppgavens tema. Både definisjonen og drøftelsen om perifere betydninger ble presentert tidligere i min artikkel - Janik (2013).

19 Begrepene: prototypisk og perifer blir brukt i samsvar med prototypeteorien først framstilt i Rosch (1987), og så tilpasset til språkvitenskapen av Lakoff (1987). 
Det første trinnet i utarbeiding av en definisjon av en ordklasse er å velge, eller snarere priorotere, kriterier som vil tjene en til å skille den ene ordklassen fra de øvrige. Som vist ovenfor, har de norske grammatikerne stort sett satt morfologiske kriterier høyest, unntatt Hagen (1998) som har prioritert syntaktiske og semantiske kriterier. Det samme vil jeg gjøre i denne definisjonen ettersom avhandlingens tema er tilegnelse av adjektivkongruens, og kongruens er jo et syntaktisk begrep. Dessuten hevder Bhat (1994: 2) at ordets betydning og funksjon er sterkt knyttet sammen, og at de alene danner et tilstrekkelig grunnlag til at ordet blir klassifisert i en eller annen ordklasse. Ifølge ham kan ordets andre karakteristikker (først og fremst morfologi) deriveres fra dets syntaktiske og semantiske egenskaper, men siden semantikk ikke utgjør noen større rolle i denne oppgaven, vil jeg konsentrere meg mest om adjektivets syntaktiske trekk her, og bare anmerke betydningens viktigste aspekter.

Når det gjelder betydningen til det prototypiske adjektivet, vil jeg bare gjenta det de norske lingvistene påstår, og som Bhat (1994: 23) uttrykker slik: «Adjectives have to denote a single, specific property with the help of which the reference of their head noun can be restricted or suitably modified». Ifølge ham er adjektivets rolle altså å modifisere substantivet slik at det kan denotere referenten så nøyaktig som mulig. Her er det synlig hvordan adjektivets betydning (denotering av en enkelt egenskap) samvirker med dets funksjon (modifisering av substantivet). Det kan dannes flere inndelinger basert på adjektivets betydningsaspekter, blant annet foreslår NRG (1997: 346) å dele denne ordklassen etter permanente (f.eks. størrelse, form, smak) og midlertidige (f.eks. livstilstand, sinnstilstand, temperatur) egenskaper ${ }^{20}$. Det viktigste her er nok at det primært dreier seg om enkelte egenskaper, og ikke sammensatte, slik det er i tilfellet substantiver. For å illustrere forskjellen mellom enkelte og sammensatte egenskaper, kan det

20 Flere semantiske inndelinger av adjektivet blir presentert $\mathrm{i}$ neste underkapittelet. 
brukes følgende eksempel: substantivet hus rommer i seg flere egenskaper: både størrelse, bredde, høyde, lengde, alder, farge, lukt, materiale og så videre, mens adjektivet gammel uttrykker bare alder, og adjektivet høy uttrykker bare høyde.

Basert på alle de definisjonene omhandlet tidligere i dette underkapitlet og på mine egne observasjoner vil jeg beskrive det prototypiske adjektivets funksjon som både attributiv og predikativ, for her er samspillet med betydningen maksimalt. Adjektivet kan hjelpe substantivet med å denotere referenten presisest mulig ved å modifisere substantivet (Bhat 1994: 43), og det gjør det $\mathrm{i}$ de to funksjonene: den attributive og predikative. Etter Bhats mening er den attributive funksjonen dog mer prototypisk enn den predikative, noe han uttrykker slik: «Adjectives show the maximum number of differences from verbs only in the former [attributive] usage. They are more similar to verbs in the latter (predicative) usage» (Bhat 1994: 47). Han skiller imidlertid mellom flere bruk adjektivet kan ha enn bare de to - han lager et slags mellom-trinn som kan plasseres mellom den attributive og den predikative funksjonen, og deretter ordner han dem i en rekkefølge fra de mest til de minst prototypiske. I hans gradering fremstår det norske predikative adjektivet som ganske nært det attributive ettersom det forekommer med hjelpeverb (Bhat 1994: 110). Av den grunn er det praktisk å betrakte begge funksjonene (dvs. den attributive og den predikative) på lik måte. Bhats drøftelser gjelder altfor mange språk, og er altfor generelle for at det blir hensynsfullt å omtale dem nøyere her.

Det ble nevnt også to andre funksjoner til adjektivet. NRG (1997: 392-393) omtaler både adverbialfunksjonen og funksjonen som adledd i adjektivfraser. På grunn av at de ikke forekommer ved alle adjektiver og at de funksjonene kan betraktes som særegne norske (dvs. at de ikke er generelle - det finnes språk, f.eks. polsk, som ikke betrakter de funksjonene som adjektiviske, men heller som adverbiale), kan de ikke betraktes som prototypiske. Kulbrandstad (2012: 173) hevder at det vanligvis er adverb som har de funksjonene. Det å endre sine 
opprinnelige syntaktiske funksjoner kan vurderes i termer rekategorisering (det å bli knyttet til en ny klasse) og dekategorisering (det å miste sin opprinnelige tilhørighet til en klasse) i Bhats (1994: 92) forstand.

Adjektivets morfologiske egenskaper er underordnet de semantiske og syntaktiske: «Morphosyntactic characteristics derive from semantic factors and (...) both of them get motivated by functional factors» (Bhat 1994: 18). I norsk har det prototypiske adjektivet både grad- og kongruensbøyning. Man skiller mellom tre grader: positiv, komparativ og superlativ. Det prototypiske adjektivet kan graderes $\mathrm{i}$ alle de tre gradene, men mer perifere adjektiver mangler ofte denne muligheten. Gradbøyningen ved adjektiver er et godt eksempel på hvordan ordklassens morfologiske egenskaper stammer fra de semantiske. Fordi adjektiver uttrykker enkelte egenskaper, er det mulig å gradere dem, som i gammel - eldre - eldst eller høy - høyere - høyest. Det er et trekk som skiller dem fra substantiver, som utrykker sammensatte egenskaper (f.eks. hus refererer både til dimensjonen, størrelsen, formen, fargen osv.), og som derfor ikke kan graderes (Bhat 1994: 23).

Den adjektiviske kongruensbøyningen ,har bare ei reint syntaktisk oppgåve" (Rønhovd 1993: 44) - den viser substantivets tilknytning til substantivet det står til. NRG forklarer det slik: «Av og til blir det ikke nødvendigvis tilføyd et nytt betydningselement ved bøyning. I stedet blir et betydningselement som er uttrykt ved et annet ord, gjentatt» (NRG 1997: 19), og Rønhovd (1993: 44) kaller det for «kopiering» av kategoritrekk fra et substantiv til adjektivet. I likhet med de norske lingvistene jeg har referert til, vil jeg beskrive det prototypiske adjektivet med samsvarsbøyning i følgende tre kategorier: tall, genus og bestemthet. Adjektiver som ikke kan bøyes i en eller flere kategorier kan betraktes som mindre typiske. Følgelig kan adjektivene billig, blå, moderne betraktes som mindre prototypiske enn for eksempel $d y r$, rød og gammel fordi de mangler en eller flere bøyningskategorier. 
I denne oppgaven vil det altså bli brukt følgende definisjon av det prototypiske adjektivet, som også er presentert i Janik (2013):

Et prototypisk norsk adjektiv:

1) denoterer en enkelt egenskap,

2) kan brukes både som attributt og som predikativ,

3) kan grad- og samsvarsbøyes (dvs. bøyes i tall, genus og bestemthet).

De to første kriteriene er i grunnen tilstrekkelige til å kalle et ord for adjektiv, men adjektivet kan bli jo mer prototypisk, jo flere kriterier, av de ovenfornevnte, det oppfyller.

Riktignok nevnes det av og til ytterligere funksjoner ved adjektivet, det vil si adverbialfunksjonen og adleddfunksjoner i adjektivfraser (bl.a. i NRG 1997: 392-393), men de kan antakelig ikke betraktes som prototypiske. Ifølge Bhats (1994: 92) terminologi er adjektiver i disse to funksjonene snarere dekategoriserte adjektiver, det vil si adjektiver som har mistet sin opprinnelige tilhørighet til adjektivklassen) som fungerer i sin utbredte funksjon, eller med andre ord - som er rekategorisert som adverb, det vil si at de har fått noen typisk adverbiale funksjoner. Det er nemlig adverb som vanligvis fyller de to funksjonene (Kulbrandstad 2012: 173), noe man også finner i andre språk, for eksempel polsk (Wróbel 2001: 79).

Både norsk, polsk, engelsk og tysk har i grunnen det samme prototypiske adjektivet. Den eneste forskjellen danner her de morfologiske kriteriene - språkene varier i antall og type bøyningskategorier ved adjektivet, noe som imidlertid ikke påvirker adjektivbegrepet fordi, som sagt ovenfor, de morfologiske utgjør kun et tillegg til de semantiske og syntaktiske kriteriene. Det som tverrspråklige forskjeller derimot har påvirkning på, er perifere adjektiver. Grensetilfeller blir betraktet ulikt, avhengig av språkets karakter. Nedenfor omtales det imidlertid bare de norske grensetilfellene ettersom de resterende ikke er av større relevans her, og vil bli nevnt bare sporadisk, når det blir behov for det. Ordene som regnes som 
vanskelige å klassifisere er (hvis de altså ikke klassifiseres som adjektiver): noen substantiver, noen adverb, partisipper, possessiver og ordenstall. Nedenfor blir de omtalt hver for seg og gitt argumenter for eller mot å bruke dem i analysen i den foreliggende avhandlingen.

\subsubsection{Adjektiver vs. substantiver}

Man kan skille ut minst to grupper ord som enten kan regnes med i adjektiv- eller i substantivklassen. En av gruppene danner ord som for eksempel rødt, smått, nytt. Trass i at de er nøytrumsformer av adjektivene: rød, små, ny, kan de selvstendig (dvs. uten substantiver som er kjerne) danne nominalfraser, og blant annet Bokmålsordboka betegner dem som substantiver. Kulbrandstad (2012: 156) beskriver dem imidlertid som adjektiver brukt substantivisk, noe som er i tråd med Bhats resonnement der han karakteriserer slike ord som adjektiver rekategorisert til substantiver (1994: 119), noe som innebærer at de tross alt forblir adjektiver. Også i NRG (1997: 393) argumenteres det for å betrakte disse ordene som adjektiver: «Betydningen er gjerne generell: Rødt er stilig = 'røde ting er stilige', 'det som er rødt, er stilig'». Ordene kan derfor oppfattes som adjektiver i ellipsekonstruksjoner hvor substantivet er utelatt. Men siden denne «substantiviske bruken» ikke kan ansees som prototypisk ved adjektivet, og disse ordene ikke viser trekk som er vesentlige ved adjektiver (bortsett fra at de har de samme semantiske egenskapene), må de kjennetegnes som perifere adjektiver. På grunn av manglende kongruens blir de ikke analysert i denne oppgaven.

Det er dertil to ganske frekvente ord (iallfall i ASKkorpuset) som, avhengig av fortolkning, kan betegnes enten som adjektiver eller substantiver: moro og gøy (bl.a. klassifiserer Bokmålsordboka dem som både adjektiver og substantiver). Ordene er opphavlig substantiver, men de er ofte brukt i likhet med adjektiver (de bøyes f.eks. i tall), noe som kan tyde at de er på vei mot rekategorisering til adjektiver i 
Bhats (1994) betydning. Fordi moro og gøy ikke har alle egenskaper som adjektiver har, kan de i beste fall betraktes som perifere adjektiver som likevel ikke vil bli tatt inn i analysen i denne oppgaven.

\subsubsection{Adjektiver vs. adverb}

Mange norske adjektiver kan brukes som adverbialer ved å legge til en -t-endelse slik at det oppstår for eksempel: høyt, langt, fint, godt og så videre. Slike ord kan imidlertid virke vanskelige å klassifisere ettersom deres dannelsesmekanisme kan forklares på to måter: enten er det bøyde adjektiver eller adverb derivert fra adjektiver. Med andre ord er de enten nøytrumsformer av adjektivene: høyt, langt, fint, godt og så videre, eller er de adverb avledet av disse adjektivene. En sammenligning med andre språk (i det minste engelsk og polsk) vil bringe argumenter for å betrakte dem snarere som adverb enn som adjektiver siden de blir klassifisert der som sådan. Fordi disse adverbialene har den samme endelsen som attributter og predikativer i nøytrumsform, er problemet mer sammensatt, og norske lingvister mangler argumenter mot å behandle dem annerledes enn adjektiver. Hvordan disse ordene blir klassifisert, avhenger i stor grad av definisjonen man bruker i klassifiseringen. Er klassifiseringsgrunnlaget morfologisk, og gradbøyning særtrekket ved adjektiver, må ordene tas inn i adjektivklassen. Slik er det tilfellet i NRG (1997: 22). Også Hagen (1998: 345) hevder at der er bøyde adjektivformer selv om han prioriterer syntaktiske kriterier i ordklasseinndelingen sin. Rønhovd (1993: 52) i sin side nevner andre motivasjoner mot å ta disse adverbialene inn i adverbklassen - på den måten unngås det dubleringen av leksemer: «Motiveringa for ei slik dublering ville dessutan vere reint syntaktisk og knytt til den aktuelle funksjonen substantivet [i vårt tilfelle: adjektivet - min kommentar, M.O.J.] har i setninga. Morfologisk synest ei slik gruppering vanskeleg å forsvare». Man kan derfor vurdere 
denne typen ord som adjektiver dekategorisert til adverbfunksjonen (ved bruk av Bhats (1994: 145) terminologi), altså adjektiver som fungerer i sin perifere funksjon. På grunn av at de verken kan brukes attributivt, eller predikativt i setningen, og at de ikke blir samsvarsbøyd, blir de imidlertid ikke tatt med i analysen. Fordi formene til disse ordene er, som sagt, tvetydige, vil det $\mathrm{i}$ analysen bli tatt hensyn til hvilken funksjon ordene har slik at attributter og predikativer ikke blir ekskludert.

I norsk omtales ofte ordene ofte, lenge og fort (bl.a. i NRG) som adjektiver på grunn av deres evne til å gradbøyes. Likevel kan de verken stå attributivt, eller predikativt i setningen, og heller ikke kan de kongruensbøyes. Dessuten stammer de ikke fra noen adjektiver. Det er derfor ingen grunn til å klassifisere dem som sådan i denne oppgaven, og følgelig blir de ansett som adverb her.

\subsubsection{Adjektiver vs. partisipper}

Partisipper (både presens- og perfektumpartisipper) er enda en gruppe ord som kan tilhøre to ulike ordklasser: adjektiver eller verb. Trass i at de opprinnelig stammer fra verb, har de mange adjektiviske egenskaper, blant annet evne til å stå attributivt og predikativt i setningen. På samme måte som det er tilfellet med noen adjektiviske adverbialer, avhenger partisippenes tilhørighet av deres dannelsesmekanisme: de kan enten være verbale bøyningsformer, eller adjektiver derivert fra verb. Avgjørelsen om hvordan de er laget, må ofte tas arbitrært. Argumenter for å inkludere dem inn i adjektivklassen er allerede nevnt - de kan fungere både som attributter og predikativer (i tilfellet de står predikativt, blir deres tilhørighet enda mer uklart, for da utgjør de vanligvis et utbygget verbal). Likevel har de verbalt innhold, mangler gradbøyning, og deres kongruensbøying er sterkt begrenset. Av den grunn kan de ikke kategoriseres som adjektiver, eller i beste fall som perifere adjektiver. Bhat (1994: 141) problematiserer også partisippenes 
attributive funksjon, og hevder at partisippet fungerer da dekategorisert som verb, og rekategorisert som adjektiv.

I denne avhandlingen blir partisipper ansett som bøyde verbformer, og ikke som adjektiver. Dette valget vil ha vesentlige konsekvenser for analysen, og er motivert av økonomiske grunner - fordi partisippers kongruens avviker sterkt fra adjektivets, er det rett og slett umulig å analysere begge typene kongruens i denne oppgaven. Derfor velger jeg bort å analysere kongruenstilegnelse av partisipper. Som partisipper (og følgelig verb) menes det også partisipper som har blitt leksikalisert som adjektiver i norsk, for eksempel komplisert, avansert og lignende.

\subsubsection{Adjektiver vs. possessiver}

Grunnen til at possessiver bør diskuteres her, er at de viser til dels de samme egenskapene som adjektiver har - de kan fungere som attributter og predikativer i setninger, og de samsvarsbøyes med substantivet de står til. På den annen side kan de ikke gradbøyes, og - det som er avgjørende her - de bærer en annen betydning med seg enn adjektiver ellers gjør, for de uttrykker eiendoms- og tilhørighetsforhold. Det er altså uhensiktsmessig å klassifisere dem som adjektiver.

\subsubsection{Adjektiver vs. ordenstall}

Den siste gruppen problematiske ord jeg vil diskutere her, er ordenstall. Avhengig av kriterier man velger, kan de klassifiseres enten som adjektiver, eller som tallord. Fra det syntaktiske ståstedet ligner de på adjektiver på grunn av de kan fungere både som attributter og som predikativer. Likevel kan de ikke bøyes, og deres semantiske egenskaper er forskjellige fra de adjektiver har, de betegner nemlig nummer i en rekkefølge. Ordenstall blir derfor betraktet som tallord i denne avhandlingen, og ikke blir tatt med i analysen. Det eneste unntaket er ordet første som blir tatt med i analysen. 


\subsubsection{Oppsummering}

Som vist ovenfor kan adjektivklassen defineres på ulike vis, avhengig av kriterier man velger. Fordi adjektivbegrepet i denne avhandlingen skal brukes til konkrete analyser på konkrete eksempler av adjektiver, må det være klart og tydelig, slik at en uten vansker kan skille mellom adjektiver og ikkeadjektiver. Til dette formålet har jeg laget prototypedefinisjonen av denne ordklassen der det prototypiske norske adjektivet har blitt definert som et ord som denoterer en enkelt egenskap, kan brukes både i attributiv og predikativ stilling $\mathrm{i}$ setningen, og som kan grad- og samsvarsbøyes. Det finnes imidlertid ganske mange adjektiver som ikke oppfyller alle disse kravene, og som derfor kan kalles for mer perifere. De største gruppene adjektiviske ord som enten kan betegnes som adjektiver, eller som andre ordklasser, har blitt omtalt ovenfor. I denne framstillingen viser det seg at verken de omtalte substantivene eller adverbene, eller partisipper, possessiver og ordenstall blir inkludert $\mathrm{i}$ analysen. Til analysen blir det altså tatt bare de prototypiske adjektivene og de av de perifere som enten kan fungere som attributter eller som predikativer (eller begge deler) og som kan kongruensbøyes i minst én kategori. En slik avgrensning er naturligvis motivert av avhandlingens tema.

\subsection{Kongruensbegrepet}

I dette underkapittelet vil jeg ta for meg kongruensbegrepet. Først skal jeg definere konseptet og andre begreper som er forbundet med det. Så skal jeg vise hvilken funksjon kongruens har. I denne framstillingen vil jeg stort sett konsentrere meg om kongruensanalysen presentert i Corbetts Agreement (utgitt i 2006) som er et grundig og pålitelig verk om kongruensfenomenet som utgjør på en måte en oppsummering av hans tidligere arbeid, blant annet artikkelen Morphology and Agreement (utgitt i 2001). Henvisninger til andre studier vil 
også bli gjort, men hovedtanken vil basere seg på Corbett (2006). Kongruensbegrepet blir altså ikke problematisert her ettersom kongruens blir i denne avhandlingen brukt snarere som et operasjonsbegrep enn som et studieobjekt i seg selv. Underkapittelet Egenskaper ved adjektiver legger imidlertid vekt på adjektivers kongruensegenskaper, og det kan tenkes som en fortsettelse av både det gjeldende og det forrige underkapittelet.

\subsubsection{Definisjon}

I Agreement definerer Corbett kongruens (eng. agreement) som en situasjon når «one word can carry the grammatical meaning relevant to another» (Corbett 2006: 1), og Moravcsik (1988: 90) skriver om «displaced grammatical meaning» i forhold til kongruens. Corbett understreker imidlertid at kongruens bør anses som «cumulating information from different sources, not as a matter of copying» (Corbett 2006: 33).

Kongruens blir ofte sett på som først og fremst en morfologisk egenskap (f.eks. hos Spencer 1991: 21 nevnes det kongruens som et eksempel på bøyningsmorfologi) ${ }^{21}$, men Corbett (2006: 2-4) forklarer og gir bevis på at det er et fenomen som berører flere språkområder: syntaks, semantikk, morfologi, leksikologi og pragmatikk. Han begrunner denne påstanden, og gir eksempler:

Clearly, then, agreement is a matter of syntax, since the syntactic role of the items involved is of importance. Examples:

1) Mary makes pancakes.

2) The cooks make pancakes.

... Committee may be conceptualized as an entity or as several individuals. Clearly, then, agreement is also a matter of semantics. Examples:

3) The committee has agreed.

4) The committee have agreed.

21 Spencer (1991) nekter imidlertid ikke kongruensens syntaktiske funksjon. 
Past tense verbs in English do not show agreement. Clearly, then, agreement is a matter of morphology (word structure) since we require the morphology to provide the opportunity for agreement to be indicated. Examples:

5) Mary made pancakes.

6) The cooks made pancakes.

There is a single exception to the statement about the past tense in English, namely the verb be which distinguishes number in the past (was $\sim$ were). This is something that has to be stated individually for this verb, in its lexical entry. We conclude that agreement is a matter which may have to be specified in the lexicon; it is a matter of lexicology.

(Corbett 2006: 2-3)

Kongruens i pragmatikk (som ifølge Corbett 2006: 4 er et videre område kongruens finner sted) forekommer blant annet $\mathrm{i}$ slaviske språk når man for eksempel bruker flertallsformer $\mathrm{i}$ tredje person istedenfor $\mathrm{i}$ andre person flertall når man henvender seg høflig til mennesker:

1) Czy państwo mogą zaczekać? (= Kan-3PL dere vente?)

\subsubsection{Andre begreper}

Det brukes i tillegg en del andre begreper når man snakker om kongruens, og de er forklart nedenfor (definisjonene er hentet fra Corbett 2006: 4-5 og NRG 1997: 387):

Kontrollør (eng. controller) - er det ordet som styrer kongruensen (f.eks. i substantivfraser - kjernen);

Mål (eng. target) - det elementet hvis form blir bestemt av kongruens (f.eks. i substantivfraser - bl.a. adjektivet);

Domene (eng. domain) - det syntaktiske miljøet der kongruensen finner sted (f.eks. en substantivfrase);

Egenskap (eng. feature) - morfologiske kategorier som kongruens er gjeldende i (f.eks. i norsk adjektivkongruens - numerus, genus og bestemthet); 
Verdi (eng. value) - et parameter av egenskapen / kategorien (f.eks. i norsk adjektivkongruens - numerus har to verdier: entall og flertall);

Forhold (eng. condition) - en egenskap som ikke blir direkte gjenspeilt i kongruensen - en faktor som påvirker kongruensen indirekte (f.eks. ordstilling).

Kongruens må også skilles fra styring (eng. government). I kongruens har kontrolløren og målet den samme formen, mens i styring kontrolløren krever en gitt form av målet. Forskjellen er godt synlig i polsk, for eksempel:

Chłopak dał mi różę.

Gutten(M-SG-NOM) ga(M-SG-NOM) meg(1SG-DAT) en rose(FEM-1SG-ACC).

Det forekommer kongruens mellom chłopak 'gutten' og dat 'ga'. Verbet får en maskulin endelse på grunn av den nominale kontrolløren som er maskulin. Styring forekommer mellom verbet og pronomenet $m i$ (meg) som står i dativ og som er det indirekte objektet her, og substantivet różę (rose) som står i akkusativ og som er det direkte objektet her. Selve verbet (som er governor) for ingen kasusbøyning, det krever bare en gitt kasus ved utfyllingene, governees som har ulike funksjoner i setningen (Corbett 2006: 7). Corbett (2006: 8) lister opp flere ytterligere karakteristikker som skiller kongruens fra styring. Blant annet nevner han at det elementet som normalt er nominalt i kongruens, er kontrolløren, og i styring er det governee. Egenskapene som kongruens vanligvis omfatter, er: genus, numerus og person, mens den egenskapen som styring vanligvis omfatter, er kasus. Dessuten, når det forekommer flere mål og flere governees i én setning, får alle målene den samme formen (alle blir samsvarsbøyd på lik måte), mens governees får hver sin form, avhengig av funksjonen de har i setningen (f.eks. makeres det direkte objektet med akkusativ, og det indirekte objektet med dativ, generelt sett). 
Corbett utpeker tre generelle prinsipper ved kongruens som, ifølge ham, aldri står i strid med hverandre i kanonisk ${ }^{22}$ kongruens:

Principle 1: Canonical agreement is redundant rather than informative.

Principle 2: Canonical agreement is syntactically simple.

Principle 3: The closer the expression of agreement is to canonical (i.e. affixal) inflectional morphology, the more canonical it is as agreement.

(Corbett 2006: 26)

Corbett (2006: 9) diskuterer dessuten kanoniske aspekter ved kongruens, og gir følgende oppsummering av sin studie:

Controller: is present, has overt expression of features, and is consistent in the agreements it takes, its part of speech is not relevant;

Target: has bound expression of agreement, obligatory marking, doubling the marking of the noun, marking is regular, alliterative, productive; the target has a single controller and its part of speech is not relevant;

Domain: agreement is asymmetric (the gender of the adjective depends on that of the noun), local, and the domain is one of multiple domains;

Features: lexical (in one instance), matching values, not offering any choice in values;

Condition: no conditions.

Corbett (ibid.) selv understreker at de kanoniske eksemplene ikke nødvendigvis er de mest frekvente i verdens språk. I den neste seksjonen omtaler jeg kongruens i norsk og polsk.

22 Corbett (2006) bruker begrepet kanonisk heller enn prototypisk, og begrunner valget slik at prototypisk forutsetter at det finnes et reelt eksempel som kan oppfattes som sådan, mens kanonisk ikke krever et reelt eksempel, og kan oppfattes som ideelt. 


\subsection{Egenskaper ved adjektiver}

\subsubsection{Innledning}

Dette underkapittelet vil ta for seg beskrivelse av adjektivets egenskaper. Det blir her diskutert tre grammatiske hovedområder: det semantiske, syntaktiske og morfologiske. I semantikkseksjonen blir det bare gitt en generell oversikt over adjektivets mulige betydninger og det blir presentert ulike inndelinger av disse betydningene. En så innskrenket framstilling er motivert av avhandlingens tema som faktisk ikke gjelder det betydningsmessige. I de følgende seksjonene, det vil si Syntaks og Morfologi, blir det derimot presentert en grundig beskrivelse av adjektivets henholdsvis syntaktiske og morfologiske egenskaper. Det blir vist både hvilke funksjoner adjektivfraser har i setningen, hvordan slike fraser kan se ut (hvordan de er bygget), og hvilke former adjektiver har i adjektivfrasene de danner, det vil si hvordan de er bøyd i ulike typer fraser. Videre vil jeg kort diskutere variasjonen i adjektivbøyning i de to norske skriftnormene: bokmål og nynorsk, og i talemål. Til slutt skisserer jeg de morfologiske egenskapene ved de polske, engelske og tyske adjektivene, og presenterer en grov sammenlikning av disse i forhold til de morfologiske egenskapene det norske adjektivet har.

\subsubsection{Semantikk}

Selv om fokuset i denne oppgaven er lagt på syntaks og morfologi, er det slik at «ordet må (...) ha både en form og et innhold» (Golden 2009: 15), derfor må det semantiske aspektet ved adjektivet også berøres her. Adjektivets viktigste semantiske rolle er å uttrykke ikke-temporale og ikke-dimensjonale egenskaper (Cruse 2000: 289). Det finnes flere mulige inndelinger av adjektivklassen $\mathrm{i}$ henhold til betydning, og for eksempel NRG (1997) introduserer seks slike inndelinger hvorav noen er overlappende. Inndelingene NRG (1997) presenterer, er generelt sett tverrspråklige, og de finnes i flere språk. 
Cruse (2000: 290) nevner to hoveddikotomier i klassifiseringen av adjektiver. For det første skilles det mellom graderbare (gradable) og ikke-graderbare (non-gradable) adjektiver. I NRG (1997: 347) er det tre steg av graderbarheten - det nevnes ubestemte, halvpresise og presise adjektiver. Til den første gruppen hører adjektiver som kan graderes, for eksempel: høy, kald, ren. Presise adjektiver har en nøyaktig betydning som ikke kan graderes, som for eksempel: $d ø d$, norsk, administrativ. Halvpresise adjektiver er «i en mellomstilling mellom de presise og de naturlig graderbare (...), [og de] kan nok graderes, men (...) [de] oppfattes ikke like lett som punkter på en skala» (ibid.). Her faller det blant annet: fri, alvorlig, gul. Å dele adjektiver etter deres mulighet til å bli gradert kan virke, avhengig av definisjonen man bruker, i strid med adjektivbegrepet ettersom gradbøyning ofte betraktes som klassifiseringsgrunnlag for adjektiver (bl.a. i NRG 1997: 22 og Rønhovd 1993: 85). Hofherr (2000: 6) hevder imidlertid at selv om adjektivets mulighet til å bli gradert ikke kan betraktes som dets prototypiske egenskap, er den ofte den avgjørende komponenten av adjektivets betydning.

For det andre gjør Cruse (2000: 290) en forskjell på absolutte (absolute) og relative (relative $=$ syncategorematic) egenskaper ved adjektiver, eller ifølge NRG (1997: 346): inherente (iboende) og relative egenskaper ved adjektiver. Det sies i NRG (ibid.) at: «Adjektiver som betegner inherente egenskaper beskriver noe direkte: en svart katt», mens relative egenskaper betegnet av adjektiver må sees i forhold til substantivet adjektiver står til, noe som eksempelfrasene med stor og liten viser: ei stor flue, en liten elefant ${ }^{23}$. Selv om flua er stor, er den fremdeles mindre enn elefanten. Ved hjelp av adjektivet stor understrekes det bare at flua er større enn en vanlig flue. Ordet stor blir ansett av McNally \& Kennedy (2008: 8) til å være et typisk eksempel på et relativt adjektiv med en åpen skala (an open-scale relative adjective), det vil si et adjektiv som uttrykker en skala uten øvre grense.

${ }^{23}$ Eksemplene hentet fra NRG (1997: 346-347). 
Videre skiller NRG (1997: 346) mellom adjektiver som uttrykker permanente og midlertidige egenskaper, også kalt $k$ valiteter og tilstander. Permanente egenskaper gir uttrykk for blant annet: størrelse (stor, kort, bred, tykk), form (krokete, flat), farge (blå, lys), lydstyrke (dump, skarp), smak (sur, bitter), taktilitet (myk, sløv), mens tilstander gir uttrykk for blant annet: livstilstand (gammel, levende, syk), sinnstilstand (trøtt, trist, redd), temperatur (varm, kjølig).

Et annet skille går mellom adjektiver som viser til objektive egenskaper versus subjektive egenskaper (vurderinger) (ibid.). Eksempler på de førstnevnte er: sur, blå, levende, og på de sistnevnte: god, pen, hyggelig. Det er dessuten mulig å bruke adjektiver som uttrykker objektive egenskaper i overført betydning for å vurdere, for eksempel i utsagnet en stor taler.

De to ovenfornevnte inndelingene kan sammenkobles slik at det oppstår en ny inndeling der man skjelner mellom klassifiserende og beskrivende adjektiver (ibid.). I den første gruppen kommer det adjektiver som uttrykker permanente og objektive egenskaper, og i den andre - de som uttrykker midlertidige og subjektive adjektiver.

Den siste inndelingen NRG (1997) nevner, skiller mellom karakteriserende og epistemiske adjektiver. De førstnevnte «avgrenser, eller karakteriserer den mengde som oppfattes av det substantivet det står til» (NRG 1997: 346), som for eksempel svart i en svart katt begrenser referansen til bare de kattene som er svarte. Derimot epistemiske adjektiver «betegner ikke (...) egenskaper ved substantivet, men om det er noe reelt eller ikke, i hvor stor grad det er reelt, om det kan bli reelt osv.» (ibid.). Eksempler på epistemiske adjektiver er: virkelig, falsk, mulig.

\subsubsection{Syntaks}

Adjektivets funksjon er å danne adjektivfraser (AP) som i sin tur kan ha flere mulige funksjoner i setningen. De kan enten være selvstendige setningsledd (innenfor setningsgrensen), 
eller utgjøre en del av mer komplekse fraser. Adjektivfrasenes interne struktur er hypotaktisk (underordningsfraser), men de kan naturligvis også danne parataktiske fraser (sideordningsfraser) (Kulbrandstad 2012: 186, 193, Lie 1979: 14, 16). APs struktur varierer fra å bestå av kun kjerne (= adjektivet) til å danne hele leddsetninger (Vassenden 1993: 57). Nedenfor presenterer jeg først adjektivfrasens ulike funksjoner i setningen, og så deres interne struktur.

For å presentere frasestrukturer bruker jeg trediagrammer i denne seksjonen siden de kan illustrere frasestrukturer på en oversiktlig måte. De er imidlertid bare verktøy her som ikke har noe med den generative tilnærmingen å gjøre. Trediagrammene som blir presentert i denne seksjonen, har en binær struktur, og refererer til setningens overflatestruktur definert av Åfarli \& Sakshaug (2006: 279) som «Struktur derivert frå ein djupstruktur ved hjelp av flytningsreglar og/eller innsetjingsreglar». Dypstrukturen $^{24}$ er i sin tur definert på følgende måte: «Den felles underliggjande strukturen som setningar som er i slekt med kvarandre, er deriverte frå» (ibid.: 247). Overflatestrukturen innebærer bruken av to perifere posisjoner som ligger utenfor selve setningen (eller setningen i dypstrukturen) merket som $S$. Den innerste perifere posisjonen er merket som $S$ ', og den utgjør «landingsplass for flytting eller innsetjing» (ibid.: 120), mens den ytterste perifere posisjonen er merket som $S^{\prime \prime}$, og der blir tematiserte ledd (inkludert subjekt) flyttet (ibid.: 124).

\subsubsection{AP - funksjon i setningen}

\subsection{Adledd i NP}

Substantivfraser (NP-er) har substantiver som kjerner, og kan ta mange ulike adledd, både pre- og postmodifiserende. Adledd i NP-er deles ofte i to typer: bestemmere og beskrivere. De vanligste premodifikatorer i NP-er er: determinativfraser (DetP-er), NP-er, og AP-er, og de vanligste postmodifikatorer

${ }^{24}$ Dypstrukturer blir ikke vist i denne avhandlingen. 
er: preposisjonsfraser (PP-er), relativsetninger og infinitivskonstruksjoner (som kan klassifiseres som verbfraser (VP-er), Åfarli \& Sakshaug 2006: 159). Leddfølgen i NP-er er bestemt, og ser slik ut: 1) totalitetskvantifiserende adledd (f.eks. alle), 2) definittmarkerende adledd (f.eks. de), 3) delkvantifiserende adledd (f.eks. tre), 4) beskrivende adledd (f.eks. store), 5) kjerne (f.eks. bilene), 6) etterstilte possessiver (f.eks. hans), 7) lokaliserende adledd (f.eks. i garasjen), 8) setningsadledd / relativsetning (f.eks. som han sjelden kjører) (Hagen 1998: 371).

Adjektivfraser fungerer som beskrivende adledd i NP-er, og er som regel foranstilte (f.eks. i: et deilig måltid, en meget glad kunde, et nokså lite modent eple), men i noen tilfeller kan de også stå etterstilt (f.eks. Her kommer høsten, våt, men skjønn). Kjernen i AP-en samsvarsbøyes med kjernen i NP-en. AP-er som er adledd i NP-er, kan ha ulik struktur, og kan være både side- og underordnet. Noen AP-er splittes slik at de kommer både foran og etter kjernen i NP-en: en så god roman at selv Tor gadd å lese den ut (Hagen 1998: 379). I slike tilfeller er det gjerne snakk om ekstraponering, det vil si omplassering av (vanligvis tunge) ledd fra den kanoniske posisjonen til en posisjon lenger til høyre i setningen (Åfarli \& Sakshaug 2006: 138). Ekstraponering er begrunnet stilistisk. Flytting av tunge ledd til høyre i setningen fremmer dessuten prosessering ettersom venstretunge ledd er sagt å være prosesseringsbelastende (Hagen 1998: 379).

\subsection{Predikativ}

Predikativledd blir definert av Åfarli \& Sakshaug (2006: 62) som «ein type ledd som viser til eigenskapar eller karakteristikkar som seier noko om det som subjektet eller det direkte objektet viser til». Lie (1979: 82) i sin tur definerer predikativet som «et nominalt ledd som enten 1) kongruerer i kjønn og tall med subjektet (eller objektet) eller 2) er identisk med subjektet (eller objektet)». Han tar som forbehold til denne definisjonen refleksive og resiproke pronomener, og predikativer som står til 
infinitivsetninger. Det skilles følgelig mellom to typer predikativer: subjekts- og objektspredikativer. Avhengig av hvilket setningsledd de står til (kongruerer eller er identiske med) utgjør de subjektet eller det direkte objektet. Predikativet er normalt en del av predikatet, og kan enten være fast (nødvendig i setningen) eller fritt (når det kan tas bort) (jf. Kulbrandstad 2012: 217). De hyppige verbene som kan ta predikativer er: vore, bli, synes, virke, se ut, høres, gå, stå, hete, kalles o.fl. (jf. Lie 1979: 85). Adjektivfrasene i setningene nedenfor er subjektspredikativer i setningene 1 og 2, og objektspredikativene i setningene 3 og 4 . I setningen 1 er det snakk om faste predikativer, og i setningene 2, 3 og 4-om frie predikativledd:

1. Huset er rødt.

2. De kom hit ekstremt slitne.

3. De malte huset rødt som valmue.

4. Hun drakk vannet kaldt.

AP-er som danner predikativer kan ha ulik struktur, og bestå av enten naken kjerne, eller ta pre- og postmodifikasjon. I visse tilfeller, og ganske ofte når det predikative adjektivet tar komplementærledd, kan kongruensen mangle ved adjektiver som står til substantiver i flertall. Dette innebærer at å kongruensbøye predikativer blir ugrammatisk i disse tilfellene (Hagen 1998: 363$)^{25}$ :

5. Elevene er klar (*klare) over at de må lære om norsk.

6. Carlo og Betty er flink (*flinke) til å kjøre bil.

25 Mer om adjektivbøyning i predikativstilling finnes i Morfologiseksjonen på s 106 . 


\subsection{Adverbial}

NRG (1997: 773) skiller mellom tre typer adverbialer, og AP-er kan danne hver av de tre typene, det vil si: bundne adverbialer (som står som utfylling til sitt styringsverb), frie adverbialer (som er adledd til verbet, men som ikke er bestemt av styringsverbet) og setningsadverbialer (som står utenfor predikatet). Adverbialer (frie og bundne) kan deles inn i flere grupper på semantisk grunnlag. Oftest er det snakk om tids-, steds-, måtes- og årsaksadverbialer (Kulbrandstad 2012: 218-219). Når en AP danner et bundet adverbial, er det vanligvis måtesadverbial (Hagen 1998: 345, NRG 1997: 788), for eksempel: De oppfører seg godt. Når en AP danner et fritt adverbial, påstår NRG (1997: 802) at det enten tids-, måls- eller måtesadverbial. I samsvar med adjektivdefinisjonen i denne avhandlingen, er det vanskelig å snakke om adjektiviske tidsadverbialer ettersom det ikke finnes noen vanlige adjektiver som kan danne denne typen adverbial. I NRG (1997: 802) nevnes det ordene: lenge, ofte og snart, men de er ikke klassifisert som adjektiver i denne oppgaven. Likevel kan de to andre typene frie adverbialer NRG (ibid.) lister opp, dannes av adjektiver. Et eksempel på målsadverbial kan være langt i: De har kommet langt, og et eksempel på måtesadverbial er stygt i: Han skriver stygt. Det er dessuten en gruppe adjektiver som kan fungere som setningsadverbial, blant annet: eventuelt, naturlig, teoretisk, typisk, utvilsom (NRG 1997: 811).

Kjerner i AP-er som fungerer som adverbialer, er bøyd, og står i nøytrum singularis ${ }^{26}$. Mer om dette står i Morfologiseksjonen på side 134.

26 De er altså klassifisert som adjektiver i samsvar med adjektivdefinisjonen framstilt $i$ denne avhandlingen. Ifølge andre definisjoner er kjerner i AP-er som fungerer som adverbialer, enten klassifisert som adjektiver eller adverb. Det samme gjelder adledd i AP (jf. s. 74). 


\subsection{Adledd i AP}

En adjektivfrase kan være et ledd av en overordet AP (NRG 1997: 395). I slike tilfeller står den underordnede AP-en som premodifikator. AP-en som er adledd i en annen AP består vanligvis av naken kjerne, som tar nøytrumsform ${ }^{27}$, men den kan også være videre utbygget (Kulbrandstad 2012: 193, Lie 1979: 16, Åfarli \& Sakshaug 2006: 77). Dette er eksempler på AP-er som er adledd i overordnede AP-er: svcert ung, $i$ begynnelsen sterkt beskjeden, utrolig enkelt gjennomførbar.

\subsubsection{AP - interne struktur}

Adjektivfraser er omtalt som mindre komplekse enn substantivfraser (NP-er), generelt sett (Åfarli \& Sakshaug 2006: 77). Det er vanlig at en AP bare består av kjerne (et adjektiv), og når den tar modifikatorer, er det typisk premodifikator. Likevel er postmodifikatorer også mulige (ibid.).

\subsection{Kjerne}

Kjerne i en AP kan bestå av enten et adjektiv eller et (presens eller perfektum) partisipp. Perfektum partisippenes funksjon som predikativer er imidlertid i de fleste tilfellene tvilsom, og det er rimelig å si at de ikke kan danne AP-er i predikativfunksjonen siden de i slike tilfeller inngår i verbfrasen (VP) som på samme måte som andre infinitte verbaler (Lie 1979: 17). Ettersom partisippene ikke blir analysert i denne avhandlingen, blir diskusjonen rundt perfektum partisippenes funksjon som predikativer ikke utviklet her.

Mange AP-er består av kun kjerne, og Diagram 1 viser strukturen av en slik frase. Det forekommer foruten ganske ofte paratakse i AP-er, og i slike tilfeller sies det at AP-en består av to eller flere kjerner forbundet med hverandre enten med

${ }^{27}$ Se også fotnote 26. 
konjunksjoner (KJS) (ofte ikke implisitt oppgitt, men erstattet av komma), noe Diagram 2 viser.

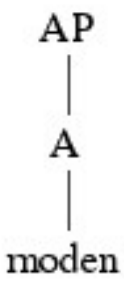

Diagram 1: En AP med bare kjerne

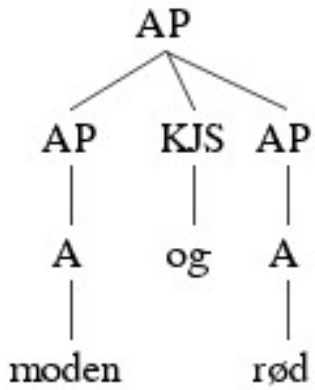

Diagram 2: En AP med to kjerner

Når to adjektiver står ved siden av hverandre uten noen konjunksjon, kan AP-en noen ganger virke tvilsom som enten en parataktisk eller hypotaktisk frase. NRG (1997: 401) angir noen eksempler på hypotagmer som kan ved første øyekast sees som paratagmer: en økonomisk solid person, et vitenskapelig uholdbart argument, en faglig dyktig person ${ }^{28}$. I tillegg til det kan to adjektiver som er plassert ved siden av hverandre komme inn i to ulike fraser slik som i: en $n y$ økonomisk politikk ${ }^{29}$, der

${ }^{28}$ NRGs (1997: 401) eksempler.

${ }^{29}$ NRGs (1997: 407) eksempler. 
$n y$ er adledd til NP-en økonomisk politikk (hvor økonomisk er igjen adledd til NP-en politikk).

Formen av adjektivet som er kjerne i en AP avhenger både av adjektivets inherente morfologiske egenskaper, og av dets funksjon. Når AP-en er attributt eller predikativ, samsvarsbøyes kjernen (el. kjernene) med det ordet den (de) står til. Fungerer AP-en som adverbial eller adledd $\mathrm{i}$ en annen AP, står den $\mathrm{i}$ nøytrum. En omfattende omtale av adjektivets morfologi befinner seg i neste seksjon.

\subsection{Premodifikator}

Premodifikasjon er mer vanlig ved AP-er enn postmodifikasjon (Åfarli \& Sakshaug 2006: 77), og den vanligste typen adledd som kommer foran kjernen er enten nye adjektivfraser eller adverbfraser (AdvP), som i sin tur oftest forekommer som bare kjerner uten tillegg (Kulbrandstad 2012: 193, Lie 1979: 16, Åfarli \& Sakshaug 2006: 77), og som oftest er gradsadverbialer. Fordi ulike gradsadverbialer kan kombineres med ulike grader, har NRG (1997: 394-402) delt premodifikatorer inn på semantisk grunnlag, avhengig av adjektivets grad. Diagram 3 gir et eksempel på en AP med en AdvP som premodifikator, og Diagram 4 viser en AP med en annen AP som premodifikator. 


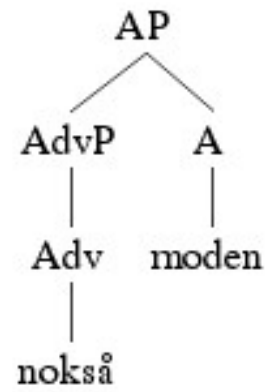

Diagram 3: En AP med AdvP som premodifikator

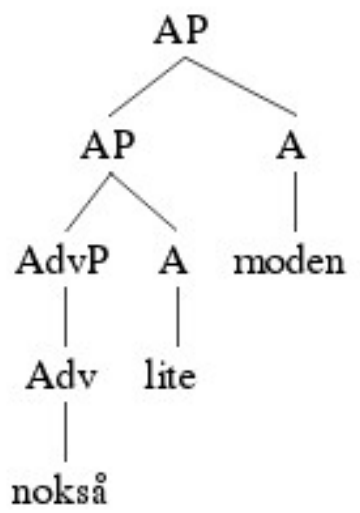

Diagram 4: En AP med AP som premodifikator

Også preposisjonsfraser (PP) kan danne premodifikatorer, men da virker de skriftspråklige (i motsetning til når de er postmodifikatorer, der de får et mer muntlig preg, Lie 1979: 17). NRG (1997: 400) kaller slike adledd attributiv sperring. Vassenden (1993: 56-57) angir flere eksempler på slike uvanlige premodifikatorer, blant annet: (ein) av den grunn 
utruleg spennande (film) ${ }^{30}$. I denne AP-en er premodifikatoren av den grunn utruleg en PP, og hele AP-en har struktur som vist i Diagram 5.

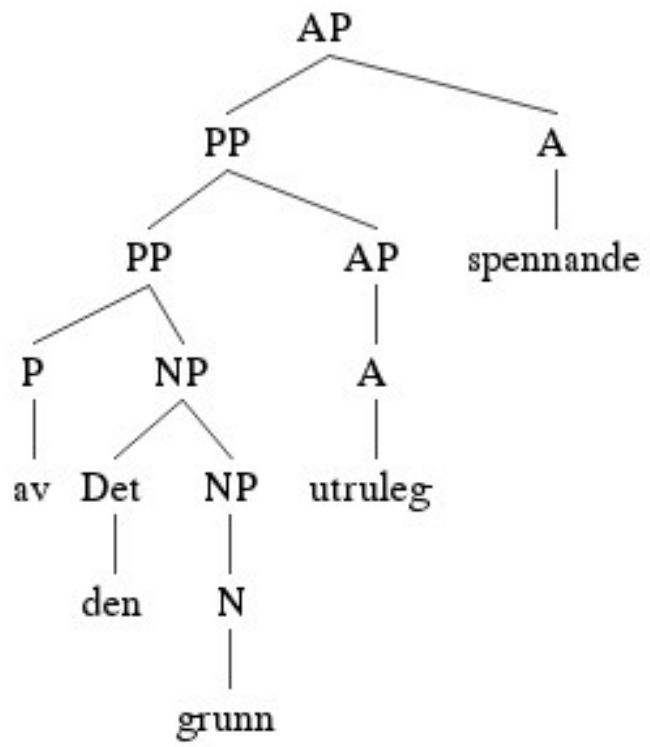

Diagram 5: En AP med PP som premodifikator

\subsection{Postmodifikator}

Postmodifikatorer kan deles inn i to grupper: utfyllinger (komplementer) og andre adledd. De mest utbredte typende postmodifikatorer er NP-er (f.eks. Hun er redd slanger.) og PPer (f.eks. Jeg er glad i brunost.), men også AdvP-er (f.eks. Han er ikke rask nok.), infinitivskonstruksjoner (som kan klassifiseres som VP-er, Åfarli \& Sakshaug 2006: 159) (f.eks. Oppgaven er lett å løse.) og leddsetninger (f.eks. Hun er så kjedelig

30 Vassendens (1993: 57) eksempel. Her er et presens partisipp, spennande, kjerne i AP-en, men den kan erstattes av et mer prototypisk adjektiv, f.eks. morsom. 
at hun ikke har venner.) er vanlige (Kulbrandstad 2012: 193). Når en leddsetning er postmodifikator, trenges det som regel også en premodifikator (i dette eksemplet $s a ̊)$. Hver av postmodifikatorene kan dessuten bestå av en mer eller mindre utbygget frase. Trediagrammene nedenfor viser hvordan en AP ser ut med de ulike typene postmodifikatorer.

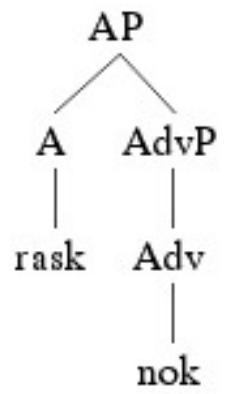

Diagram 6: En AP med AdvP som postmodifikator

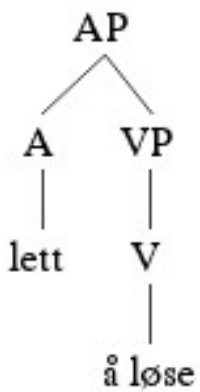

Diagram 7: En AP med VP (infinitivskonstruksjon) som postmodifikator 


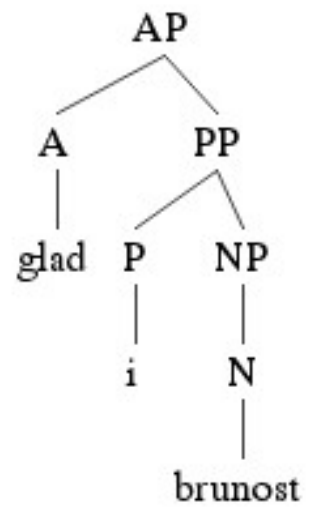

Diagram 8: En AP med PP som postmodifikator

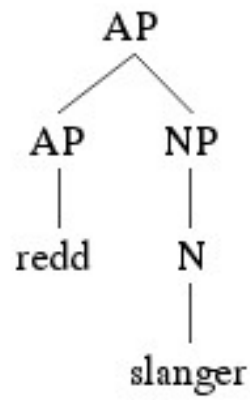

Diagram 9: En AP med NP som postmodifikator 


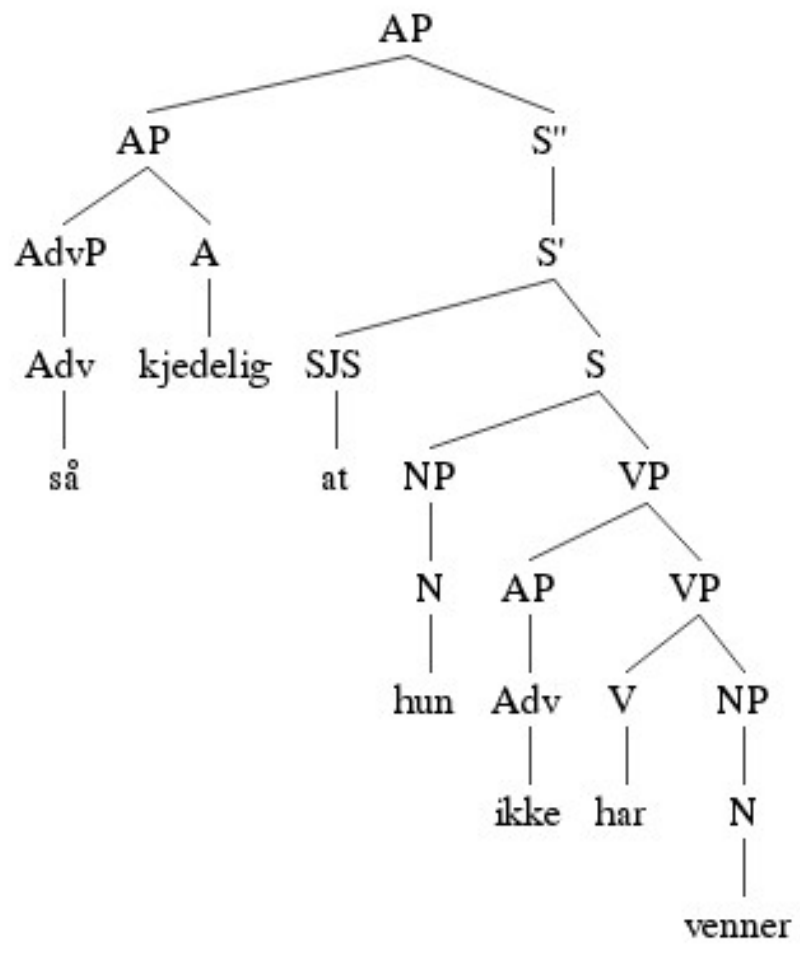

Diagram 10: En AP med leddsetning som postmodifikator

Avhengig av adjektivfrasens funksjon i setningen, må kjernen bøyes på riktig måte: enten må det samsvarsbøyes med substantivet det står til, eller markeres dens adverbialfunksjon. Bøyningen er omtalt i den neste seksjonen.

\subsubsection{Morfologi}

Det norske adjektivet samsvarsbøyes med substantivet det står til i tre kategorier: tall, genus og bestemthet. Tall- og bestemthetskategorien har to trekk, mens genuskategorien har tre trekk. Hagen (1998: 114) tilskriver trekkene til kategoriene på følgende måte: 
Kategorien numerus har to trekk: pluralis og singularis.

Kategorien bestemthet har to trekk: bestemt og ubestemt \& predikativ.

Kategorien genus har tre trekk: nøytrum, femininum og maskulinum.

Med bestemt-trekket mener Hagen (ibid.) attributt i nominativfrase med definitt referanse. Både NRG (1998: 366) og Rønhovd (1993: 107) nevner de samme kategoriene og trekkene.

De fleste norske adjektivene bøyes i norsk bokmål på samme måte i hankjønn og hunkjønn, bortsett fra ett adjektiv liten som ikke viser en slik synkretisme (Hagen 1998: 115). Slik kan det sies at genuskategorien har egentlig to trekk: felles form for maskulinum og femininum, og nøytrum (med liten som unntak). Likevel forekommer det i enkelte dialekter flere adjektiver som bøyes forskjellig $\mathrm{i}$ hankjønn og hunkjønn for eksempel i Møre og Romsdal, Sogn og Fjordane, Hordaland, Rogaland og flere (Sandøy 1988: 87), og av den grunn er det rimelig å påstå at genuskategorien har tross alt tre trekk: maskulinum, femininum og nøytrum.

Hagen (ibid.) foreslår dessuten et hierarki av adjektivkategoriene. Han illustrerer hierarkiet i form av en diagram (Diagram 11):

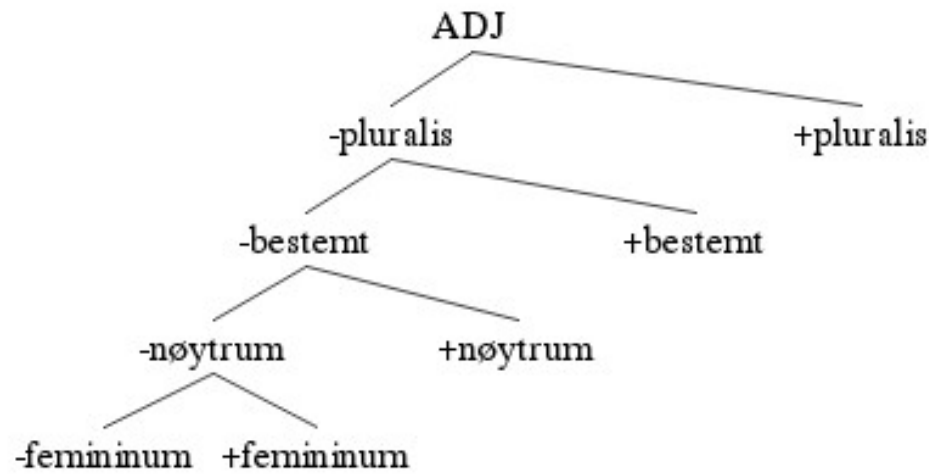

Diagram 11: Hagens (2008: 115) hierarki for adjektivkategoriene 
Hierarkiet foreslått av Hagen har en ulempe, nemlig den at det dekker adjektiver bare $\mathrm{i}$ attributiv stilling. Ved adjektiver som fungerer som predikativer, skilles det ikke mellom bestemt og ubestemt form, men det skilles der mellom entall og flertall. Av den grunn vil jeg modifisere Hagens diagram, og bytte plassene til tall og bestemthet slik det er i Diagram 12. Det nye hierarkiet har også en ulempe. Det dekker alle adjektivene unntatt ett - liten som har den samme formen i pluralis ubestemt og bestemt form (små), men en annen form i singularis bestemt form (lille, vesle). I dette tilfellet passer Hagens diagram best, men det at Diagram 12 ikke inkluderer liten, kan sies å være en forholdsvis liten ugagn i forhold til muligheten til å inkludere hele predikativfunksjonen inn i diagrammet. Dessuten er skilnaden mellom sterk ([-bestemt]) og svak ([+bestemt]) bøyning synlig nettopp i Diagram 12, og grammatikere som primært skiller mellom de to typene bøyning, støtter det implisitt (det gjelder bl.a. Golden, Mac Donald \& Ryen (2014: 20), NRG (1997: 366), Kulbrandstad (2012: 152), Rønhovd (1993: 107) og flere).

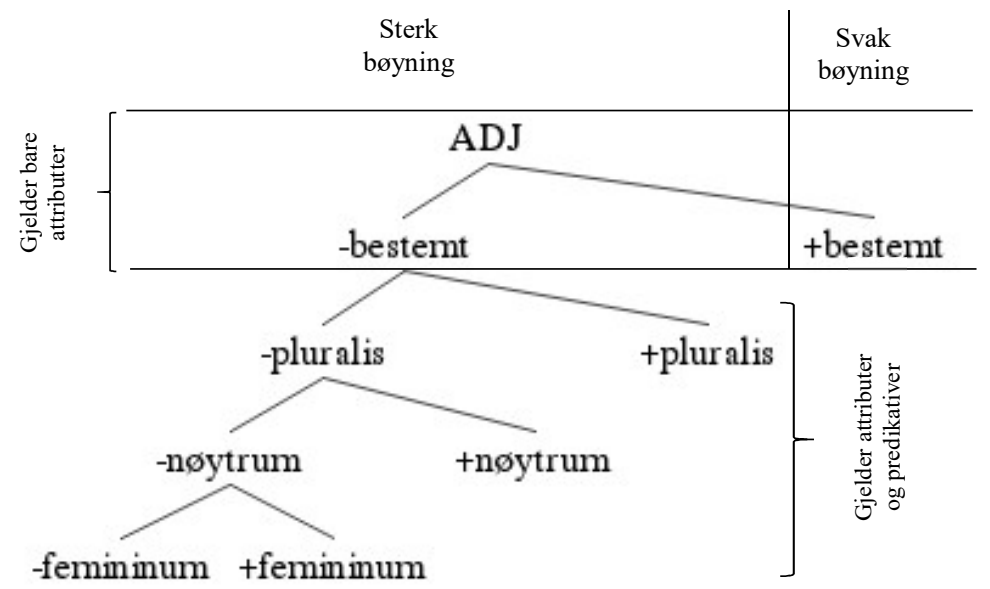

Diagram 12: En modifisert hierarki av adjektivkategoriene 
Videre i denne seksjonen vil det bli tatt for seg hvordan adjektivets ovenfornevnte kategorier og kategoritrekk danner bøyningsparadigmer av norske adjektiver. Først blir hovedregelen presentert, så omtales det modifikasjoner av hovedregelen og avvikende bøyning.

\subsubsection{Bøyning}

\subsection{Hovedregelen}

Når man ser på antall ulike samsvarsbøyningsendelser ved norske adjektiver (både i bokmål og nynorsk), ser situasjonen ganske fin og enkel ut - det er nemlig tre endelser å velge blant: $\varnothing$ (null-endelse), - $t$ og $-e$. Heller ikke fordelingen av endelsene ser komplisert ut. Ingen endelse brukes når adjektivet står predikativt (uansett om substantivet står i ubestemt eller bestemt form) og attributivt (i ubestemt form) til et maskulint og feminint substantiv $\mathrm{i}$ entall. Endelsen $-t$ brukes når adjektivet står predikativt til et nøytrumsubstantiv i entall (uansett om substantivet står i ubestemt eller bestemt form) og attributivt når nøytrumsubstantivet står i ubestemt form. Ellers blir -e-endelsen brukt, det vil si når adjektivet står til et substantiv i flertall (både $i$ attributiv og predikativ stilling) og attributivt til et substantiv i bestemt form, uansett genus. Den siste typen bøyning (dvs. den som gjelder attributive adjektiver som står til substantiver $\mathrm{i}$ bestemt form) kalles svak bøyning, mens bøyningen i ubestemt form $i$ attributiv stilling, og all bøyningen i predikativ stilling kalles sterk bøyning (Golden, Mac Donald \& Ryen 2014: 20, Kulbrandstad 2012: 151, NRG 1997: 366, Rønhovd 1993: 107). Tabell 2 viser fordelingen av endelsene i norsk samsvarsbøyning. 


\begin{tabular}{|c|c|c|c|c|}
\hline \multicolumn{5}{|c|}{ Adjektiv } \\
\hline & & \multicolumn{2}{|l|}{ Attributiv } & Predikativ \\
\hline & singularis & ubestemt form & bestemt form & $\begin{array}{l}\text { ubestemt form } \\
\text { og bestemt form }\end{array}$ \\
\hline \multirow{4}{*}{ 离 } & maskulinum & $\varnothing$ & $-\mathrm{e}$ & $\varnothing$ \\
\hline & femininum & $\varnothing$ & -e & $\varnothing$ \\
\hline & nøytrum & $-\mathrm{t}$ & $-\mathrm{e}$ & $-\mathrm{t}$ \\
\hline & pluralis & $-e$ & $-\mathrm{e}$ & $-\mathrm{e}$ \\
\hline
\end{tabular}

Tabell 2: Fordelingen av endelsene ved norske adjektiver

Ved bruk av hovedregelen kan man bøye de fleste norske adjektivene (Golden, Mac Donald \& Ryen 2014: 20), for eksempel: lys, stor, pen, brun, ung, sur, brutal, sløv og så videre. I Tabell 3 blir det presentert hvordan hovedregelen anvendes til adjektivet lys.

\begin{tabular}{|c|c|c|c|c|}
\hline & & \multicolumn{2}{|c|}{ Attributiv } & Predikativ \\
\hline & singularis & $\begin{array}{l}\text { ubestemt } \\
\text { form }\end{array}$ & \begin{tabular}{|l} 
bestemt \\
form
\end{tabular} & $\begin{array}{l}\text { ubestemt form } \\
\text { og bestemt form }\end{array}$ \\
\hline \multirow{6}{*}{$\stackrel{\infty}{\stackrel{\infty}{9}}$} & maskulinum & en lys dag & den lyse dagen & en dag / dagen er lys \\
\hline & femininum & ei lys natt & den lyse natta & ei natt / natta er lys \\
\hline & nøytrum & et lyst hår & det lyse håret & et hår / håret er lyst \\
\hline & \multirow{3}{*}{ pluralis } & lyse dager & de lyse dagene & $\begin{array}{l}\text { dager / } \\
\text { dagene er lyse }\end{array}$ \\
\hline & & lyse netter & de lyse nettene & $\begin{array}{l}\text { netter / } \\
\text { nettene er lyse }\end{array}$ \\
\hline & & lyse hår & de lyse hårene & $\begin{array}{l}\text { hår / } \\
\text { hårene er lyse }\end{array}$ \\
\hline
\end{tabular}

Tabell 3: Anvendelse av norske samsvarsbøyningsendelser ved adjektiver 


\subsection{Modifikasjoner av hovedregelen}

Imidlertid undergår hovedregelen ofte noen modifikasjoner som har sin kilde først og fremst i fonetiske og ortografiske/ språkhistoriske forhold. Ofte blir slike modifikasjoner av hovedregelen omtalt sammen men avstikkende kongruensbøyning, som for eksempel hos Hagen (1998: 119-122), Kulbrandstad (2012: 152-154) og Rønhovd (1993: 107-110), men både i Golden, Mac Donald og Ryen (2014: 20-21) og NRG (1997: 367-370) er de omhandlet separat som nettopp justeringer av hovedmønsteret (NRG 1997: 367). Det er til sammen fem slike modifikasjoner i de to tilnærmingene, fire av dem er felles for begge grammatikkene, mens den femte bare er omtalt i Golden, Mac Donald og Ryen (2014: 21). Hver av disse justeringene blir det nå gjort rede for.

1. Noen adjektiver som slutter på trykksterk enkelt vokal (unntatt $-a$ og $-e$ ), får lagt til - $t$ i i nøytrum, og vokalen uttales kort da. I denne gruppen faller blant annet: ny, fri, blå, grå, skrå, stø. Flere av disse adjektivene har dessuten to flertallsformer med $-e$ og uten $-e$, og formen uten $-e$ er mest vanlig (Golden, Mac Donald \& Ryen 2014: 20). I alle eksemplene nedenfor blir det ikke presentert bestemt form av adjektivene siden den alltid (med kun én unntak - liten, som er omhandlet i den neste underseksjonen under pkt. 10) er identisk med flertallsformen:

$\begin{array}{lllll}\begin{array}{l}\text { Mask. } \\ \text { Sing. } \\ \text { en } n y \text { jobb }\end{array} & \begin{array}{l}\text { Fem. } \\ \text { Sing. } \\ \text { ei } n y \text { bok }\end{array} & \begin{array}{l}\text { Nøyt. } \\ \text { Sing. } \\ \text { et } n y t t \text { krav }\end{array} & \text { Pl. } & \\ \text { en grå sky } & \text { ei grå skjorte } & \text { et grått hår } & \begin{array}{l}\text { jobber, } \\ \text { bøker, } \\ \text { krav }\end{array} \\ & & & \text { grå/gråe } & \begin{array}{l}\text { skyer, } \\ \text { skjorter, } \\ \text { hår }\end{array}\end{array}$


2. I de fleste adjektivene som slutter på dobbelkonsonant, blir den ene av de to like konsonantene utelatt i nøytrum. Adjektivet får en regelmessig - $t$-endelse i nøytrum. Herunder faller for eksempel: sann, tykk, trygg, grønn, tøff, vill:

$\begin{array}{lllr}\begin{array}{l}\text { Mask. } \\ \text { Sing. } \\ \text { en vill ulv }\end{array} & \begin{array}{l}\text { Fem. } \\ \text { Sing. } \\ \text { ei vill jakt }\end{array} & \begin{array}{l}\text { Nøyt. } \\ \text { Sing. } \\ \text { et vilt } \text { dyr }\end{array} & \text { Pl. } \\ \text { en } \text { tøff dag } & \text { eille } \text { tøff jente } & \text { et } \text { tøft } \text { år } & \begin{array}{l}\text { ulver, } \\ \text { jakter, } \\ \text { dyr }\end{array} \\ & & \text { tøffe } \begin{array}{l}\text { dager, } \\ \text { jenter, } \\ \text { år }\end{array}\end{array}$

Denne justeringen anvendes ikke til noen få adjektiver som beholder dobbelkonsonant før - $t$-en for at de kan skilles fra lignende adjektiver med enkeltkonsonant så det ikke kommer til et sammenfall av formene. Adjektivene som beholder dobbelkonsonant er for eksempel: full og viss som i nøytrum får formene: fullt, visst (og ikke fult, vist som er nøytrumsformer av ful og vis).

3. Adjektiver med $-m$ i utlyd som følger etter en kort vokal får fordoblet $-m$-en i flertall og bestemt form. En slik fordobling av - $m$-lyden er en generell ortografisk regel i norsk som ikke tillater at dobbel $-m$ skrives på slutten av et ord. Herunder faller adjektivene som for eksempel: tom, dum, stum, lam:

Mask.

Sing.

en tom boks

Fem.

Sing.

ei tom flaske

en lam gutt
Nøyt.

Sing.

et tomt rom

et lamt barn
Pl.

$$
\begin{aligned}
\text { tomme bokser, } \\
\text { flasker, } \\
\text { rom }
\end{aligned}
$$

lamme gutter,

kvinner, barn 
4. Adjektiver som slutter på -el, -en, -er får synkope i flertall og bestemt form, det vil si at de mister - $e$-en foran $-l$-en, $-n$-en og -r-en. Slik opptrer blant annet: enkel, sulten, dyster, gammel, vakker. Denne regelen går sammen med regelen ang. dobbelkonsonant (regel 2). Dersom det forekommer en dobbelkonsonant foran -el, -en, -er, blir den forenklet i flertall og bestemt form (som i vakker):

$\begin{array}{llll}\text { Mask. } & \text { Fem. } & \text { Nøyt. } & \text { Pl }\end{array}$

Sing. Sing. Sing.

en sulten mann ei sulten mus et sultent ekorn sultne menn,

$\begin{aligned} & \text { mus, } \\ \text { ekorner } & \end{aligned}$

en vakker dag ei vakker dame et vakkertsinn vakre dager, damer, $\sin n$

5. Golden, Mac Donald og Ryen (2014: 21) nevner i tillegg en femte gruppe modifikasjoner av hovedregelen. Her kommer to adjektiver som ellers kan betraktes som uregelmessige: annen og egen. Begge ser ut som en variant av adjektivene omtalt under punkt 4 ovenfor, men de oppfører seg litt annerledes enn de resterende adjektivene i gruppe 4. De mister nemlig sin utlyds- $n$ i nøytrum. Dessuten har annen en avvikende form $\mathrm{i}$ flertall og bestemt form:

Mask. $\quad$ Fem. $\quad$ Nøyt. $\quad$ Pl.

Sing. Sing. Sing.

en annen gang ei anna tid et annet ord andre ganger,

tider, ord

en egen bil ei egen gruppe et eget firma egne biler, grupper,

firmaer

Det må for øvrig nevnes her at ordet egen blir oftest regnet med i determinativer, og ikke adjektiver. Dessuten har det bare sterk bøyning. 


\subsection{Avvikende bøyning}

Bortsett fra tilfellene hvor hovedregelen for samsvarsbøyning av norske adjektiver blir modifisert (som vist ovenfor), finner det sted situasjoner når hovedregelen ikke blir brukt i fullt omfang eller i det hele tatt. Nedenfor presenterer jeg ti ulike typer avvikende bøyning.

1. Adjektiver som slutter på -ig får ikke -t-endelse i nøytrum, slik at hele entallsparadigmet ser likt ut. Eksempler på slike adjektiver er: fattig, vanlig, heldig, modig, synlig:

Mask. $\quad$ Fem. $\quad$ Nøyt. $\quad$ Pl.

Sing. Sing. Sing.

en vanlig familie ei vanlig helg et vanlig liv vanlige familier, helger, liv

en modig mann eimodigkvinne et modig valg modige menn, kvinner, valg

2. Ord som slutter på en konsonant og $-t$ får ikke -t-endelse $\mathrm{i}$ nøytrum, slik at hele entallsparadigmet ser likt ut. Herunder faller blant annet: kort, fast, svart, smart, lett:

Mask.

Fem.

Nøyt.

Pl.

Sing.

Sing. Sing.

en kort kjole

ei kort skjorte

et kort skjørt

korte kjoler,

skjorter,

skjørt

en lett penn

ei lett bok

et lett mål

lette

penner,

bøker,

mål

3. Også mange adjektiver som slutter på -sk får ikke - $t$-endelse i nøytrum. Denne gruppen omfatter først og fremst flerstavelsesord, for eksempel: fantastisk, økonomisk, hysterisk, allegorisk, og ord for nasjonalitet og språk, for eksempel: norsk, 
engelsk, tysk, polsk, østerriksk. Dessuten faller det her en del andre ord med «kompliserte konsonantgrupper i utlyd» (NRG 1997: 373), blant annet: glemsk, glupsk, hånsk, trolsk:

Mask.

Fem.

Nøyt.

Pl.

Sing.

Sing.

Sing.

en tysk film

ei tysk avis

et tysk selskap tyske

filmer, aviser, selskaper

Mask.

Fem.

Nøyt.

Pl.

Sing. Sing. Sing.

en trolsk natur

ei trolsk stemning

et trolsk smil

trolske naturer, stemninger, smil

4. Adjektiver på - $d$ får - $t$ i nøytrum avhengig av uttalen. Dersom - $d$-en blir uttalt, er - $t$-en utelatt, for eksempel i ordende: loerd, redd. Dersom - $d$-en ikke blir uttalt, skal en - $t$ legges til i nøytrum, for eksempel i ordene: rød, kald. Også perfektum partisipper som slutter på $-d$ retter seg etter denne regelen. Partisippene blir imidlertid ikke betraktet som adjektiver $\mathrm{i}$ denne oppgaven. Bøyningsparadigmet med adjektiver på $-d$ ser altså slik:

Mask. $\quad$ Fem. $\quad$ Nøyt. $\quad$ Pl.

Sing. Sing. Sing.

en loerd mann ei loerd kvinne et laerd verk loerde menn,

kvinner, verk

en kald morgen ei kald suppe et kaldt øre kalde morgener, supper, ører

5. Adjektiver som slutter på - $e$ får ingen endelse, det vil si at de er ubøyelige. Noen eksempler på slike ord er: moderne, beige, oransje, stille. Til denne gruppen hører også komparativer, for eksempel: bedre, høyere, flinkere, og presens partisipper, for eksempel: kommende, gjeldende, sovende. Partisippene blir 
imidlertid ikke betraktet som adjektiver i denne oppgaven. Bøyningsparadigmet med adjektiver på -e ser altså slik:

Mask.

Fem.

Nøyt.

$\mathrm{Pl}$.

Sing.

Sing. Sing.

en stille kveld

ei stille natt et stille hav

stille kvelder, netter, hav

en bedre løsning ei bedre bok et bedre resultat bedreløsninger, bøker, resultater

Denne gruppen kan dessuten inneholde adjektiver med valgfrie former i ubestemt entall. De ender da enten på -et eller -ete, for eksempel: rutet / rutete, rotet / rotete, stripet / stripete, prikket / prikkete. I bestemt form og i flertall slutter de imidlertid alltid på $-e$ :

Mask.

Fem.

Nøyt.

Pl.

Sing.

Sing.

Sing.

en rotet hybel

ei rotet stue

et rotet rom

rotete hybler, stuer, rom

en rotete hybel ei rotete stue et rotete rom

rotete hybler, stuer, rom

6. Heller ikke adjektiver på - $a$ får noen endelse, som for eksempel: sta, bra, rosa, lilla. Hit hører dessuten perfektum partisipper fra 1. klasse (kaste-klasse) som slutter på - $a$, blant annet: bortkasta, vaska, lukka. Partisippene blir imidlertid ikke betraktet som adjektiver i denne oppgaven. Bøyningsparadigmet med adjektiver på - $a$ ser altså slik: 
Mask.

Fem.

Nøyt.

Pl.

Sing.

Sing.

Sing.

en bra tur

ei bra helg

et bra tilbud

bra turer, helger, tilbud

en $r o s a$ genser ei rosa skjorte et rosa skjørt rosa gensere, skjorter, skjørt

Noen av disse adjektivene, for eksempel sta, kan imidlertid få -e-endelse i flertall og i bestemt form:

Mask.

Fem.

Nøyt.

Pl.

Sing.

Sing.

Sing.

en sta gutt

ei sta mor

et $s t a$ esel

sta / stae gutter, mødre, esler

7. Lånord fra engelsk som slutter på $-y$ er ubøyelige, for eksempel: corny, fancy, sexy, sporty:

Mask.

Fem.

Nøyt.

Pl.

Sing.

Sing.

Sing.

en fancy hatt

ei fancy veske

et fancy sjal

fancy hatter, vesker, sjal

en sporty drakt ei sporty kvinne et sporty utseende sporty drakter, kvinner, utseender

8. Noen adjektiver på $-s$ blir ikke bøyd, blant annet: annerledes, felles, gratis, avsides (mens andre blir delvis bøyd, f.eks. gammeldags):

Mask.

Fem.

Nøyt.

Pl.

Sing.

Sing.

Sing.

en felles middag ei felles historie

et felles hus

felles middager, historier, hus 
en gratis penn ei gratis avis et gratis kurs gratis penner, aviser, kurs

9. Adjektiver i superlativ blir bøyd avhengig av deres funksjon i setningen. Attributter får endelse $-e, \mathrm{og}$ de forekommer oftest i bestemte fraser, mens predikativer får ingen endelse, uavhengig av kjønn og tall, med mindre de inngår i en bestemt frase (mer om bruken av superlativformer er i den neste underseksjonen):

Mask.

Fem.

Nøyt.

Pl.

Sing. Sing. Sing.

den beste bilen den beste tida det beste valget de beste bilene, tidene, valgene bilen er best tida er best valget er best bilene, er best tidene, valgene

Men:

Han er den beste.

10. Adjektivet liten har totalt uregelmessig bøyning:

Mask.

Fem.

Nøyt.

Pl.

Sing.

Sing.

Sing.

en liten hund

ei lita katt

et lite rådyr

små hunder, katter, rådyr

Dessuten den bestemte formen i entall av liten faller ikke sammen med flertallsformen, og den lyder slik: lille / vesle. Den bestemte formen i flertall forblir likevel små: 
Mask.

Fem.

Nøyt.

$\mathrm{Pl}$.

Sing.

Sing.

Sing.

den lille/vesle

hunden

den lille/vesle

katta

det lille/vesle de små hundene, rådyret kattene, rådyrene

For å oppsummere, kan det skilles ut ti typer avvikende bøyning som fungerer som unntak fra hovedregelen for samsvarsbøyning og dens fem modifikasjoner. Alle disse ovenfornevnte reglene bygger på adjektivets interne struktur, dets fonologiske og ortografiske egenskaper, samt en viss konvensjon. For å kunne bruke alle disse formene riktig er kjennskap til bøyningsparadigmene imidlertid ikke tilstrekkelig. En må foruten vite under hvilke vilkår hver er formene kan eller må brukes, noe jeg vil ta om i neste underseksjon.

\subsubsection{Bruk av formene}

Bruken av de riktige formene er avhengig av den grammatiske konteksten adjektivet befinner seg i. I samsvar med generalregelen er bruken av adjektivformen i samsvarsbøyning avhengig av kontrolløren, det vil si «det ordet som styrer kongruensen» (NRG 1997: 387). Når adjektivet fungerer attributivt, er kontrolløren kjerne i substantivfrase, og når det fungerer predikativt, er kontrolløren subjekt (ved subjektspredikativer), eller objekt (ved objektspredikativer). Som vist både i Diagram $12 \mathrm{og}$ Tabell 2, skilles det mellom sterke og svake former bare i tilfellet adjektivet står attributivt. Står adjektivet predikativt, kan bare svake former brukes. Slik sett, kan det sies at når adjektivet fungerer attributivt, skal en sterk form brukes dersom kontrolløren er kjerne i en ubestemt substantivfrase. Konsekvent skal en svak form brukes dersom kontrolløren er kjerne $\mathrm{i}$ en bestemt substantivfrase. Basert på denne generalregelen oppstår det en ganske enkel inndeling av formene som ideelt sett (for den samme kontrolløren i den samme mengden) ser slik ut: 
Attr.

Attr.

Subjektspred.

Objektspred.

sterk form svak form

en $g u l$ bil den gule bilen

en bil /

å male en bil /

bilen er $g u l$

bilen $g u l$

Et mer grundig syn på saken avdekker imidlertid flere nyanser ettersom en slik ideell modell ikke forekommer alltid. Ofte er fraser bygget annerledes, og ofte er de mer utbygget enn vist ovenfor. Slike avvik fra generalregelen beror hovedsakelig på en regelstyrt bruk av sterk og svak form i attributiv stilling, og på et regelstyrt valg av riktig genus- og tallform i predikativ stilling. Fordi ulike typer avvik er knyttet til hver av adjektivets funksjoner, blir funksjonene betraktet separat i framstillingen nedenfor. Til slutt vil det også komme en kort presentering av hvilke former som brukes $\mathrm{i}$ adverbialfunksjonen og når adjektiver er adledd i adjektivfraser.

\subsection{Adjektiver i attributiv stilling}

I samsvar med generalregelen brukes sterke former av adjektiver når kontrolløren er kjerne i en ubestemt substantivfrase.

1. Derfor står adjektiver i sterk form foran ubestemte substantiver, for eksempel:

lang reise.

2. Og i ubestemte substantivsyntagmer, for eksempel:

en lang vei.

3. Dessuten brukes sterke former etter kvantorer, blant annet: all, hver, intet:

All god mat, Hver pen jente. 
Svake former av adjektiver brukes i sin tur først og fremst når kontrolløren er kjerne $\mathrm{i}$ en bestemt substantivfrase. Det skilles mellom sju typer bestemte substantivfraser i norsk der adjektiver står svakt, som vist nedenfor. Den svake formen av adjektivet brukes altså:

1. Når adjektivet står framfor et substantiv i bestemt form:

lyse dagen.

Herunder faller det også en del adjektiver som generelt sett ikke får demonstrativer i bestemt form, først og fremst: hel, halv:

hele uka.

2. Når adjektivet står etter et demonstrativ og bestemt artikkel: den lange reisen.

3. Når adjektivet står etter possessiver eller s-genitiver:

Marens lange reise, hennes lange reise.

Ordet egen som får sterk form etter possessiver, blir noen ganger betegnet som unntak her (f.eks. i Awedykowa 1976: 47, Golden, Mac Donald \& Ryen 2014: 21), men ordet kan regnes heller med i determinativklassen enn i adjektivklassen.

4. Når adjektivet står etter pronomener:

jeg syndige menneske.

5. Når adjektivet brukes i utrop og tiltale:

kjore venn,

dumme meg. 
6. Når adjektivet er en del av et navn:

Harald Hårfagre.

7. Dessuten er det en gruppe adjektiver som vanligvis forekommer bare i bestemt form, for eksempel: øvre, fremre, indre, venstre:

venstre øre.

Bruken av superlativer i attributiv stilling kan virke sammensatt. Riktignok brukes superlativer oftest i svak form i denne posisjonen, og det både foran substantiver i bestemt og i ubestemt form (her ofte i absolutt betydning eller i rangorden):

på beste måte, den lengste reisen, ypperste kvalitet, siste mote,

men når superlativer referer til mengder, brukes de i sterk form:

flest venner, minst vann.

Superlativer forekommer dessuten i sterk form «Når betydningen til substantivet og verbet henger så nøye sammen at det referensielle aspektet ved substantivet er nedtonet» (NRG 1997: 388):

Hun fikk størst oppmerksomhet.

Han har kortest hår. ${ }^{31}$

${ }^{31}$ NRGs (1997: 388) eksempler. 


\subsection{Adjektiver i predikativ stilling}

Som sagt før, kan bare sterke former brukes i predikativ stilling. Dette nivellerer forskjellen mellom kontrollører i bestemt og ubestemt form, slik at det bare er kontrollørens genus og numerus som påvirker adjektivets form. I tillegg er det fire andre ting man må ta $\mathrm{i}$ betraktning når adjektivet står predikativt.

1. Adjektiviske predikativer kan stå til at-setninger og infinitivsfraser. I slike tilfeller får predikativet $-t$-endelse:

At de besøkte oss var snilt.

$\AA$ besøke sine foreldre er snilt.

2. Når et adjektiv står predikativt til et subjekt med generisk referanse, får det $-t$-endelse uansett subjektets tall og kjønn. Subjektet må da stå i ubestemt form. Hagen (1998: 119) forklarer denne bøyningen på følgende måte: «Predikativet karakteriserer her strengt tatt ikke selve subjektreferenten, men snarere et underforstått semantisk predikat med subjektreferenten som 'logisk objekt'». Hagen illustrerer dette med parafraser:

Pannekaker er godt $\left({ }^{*}\right.$ gode $) . \quad$ A spise pannekaker er godt $\left({ }^{*}\right.$ gode $)$. En ny bil skulle vært $f$ int $(*$ fin $) . \quad$ A få en ny bil skulle vært fint $(*$ fin $) .{ }^{32}$

Slike relasjonsimpliserende substantivfraser kan ikke stå i bestemt form, for da blir adjektivet kongruensbøyd på vanlig måte:

Pannekakene er gode (*godt).

Den nye bilen er fin $(*$ fint $)$.

Dessuten er det bare en del adjektiver som kan brukes i denne typen konstruksjoner. Det er adjektiver som uttrykker smak

${ }^{32}$ Hagens (2008: 119) eksempler. 
eller vurdering (Golden, Mac Donald \& Ryen 2014: 22). Adjektiver som karakteriserer substantivet får derimot en vanlig kongruensbøyning:

Pannekaker er gule (*gult).

En ny bil er blank (*blankt) i lakken.

3. Predikativet mangler ofte kongruens når predikativet har komplementærledd. I slike tilfeller står adjektivet i maskulinum / femininum, uavhengig av subjektets (eller objektets) form. Hagen (1998: 118) nevner imidlertid at det forekommer en viss vakling i bruk av de forskjellige formene som har ført til at språksamfunnet er nå delt når det gjelder valg mellom samsvarsbøyde og ikke-samsvarsbøyde predikativer med utfyllinger:

Betty og Maria er lei (*leie) Ola!

Vi er ikke redd (?redde) deg!

Liv og Tor er $\operatorname{glad}(e) \mathrm{i}$ barna sine. ${ }^{33}$

4. Predikativer i superlativ blir ikke bøyd, uavhengig av subjektet eller objektets kjønn og tall (med mindre de inngår i en bestemt frase) - jf. med pkt. 9 i seksjon Morfologi Avvikende bøyning.

5. I noen tilfeller, særlig når subjektet / objektet referer til grupper av mennesker, «kan predikativet rette seg etter betydningen» (NRG 1997: 391), og få da flertallsform selv om substantivet står i entall:

Politiet er sikre på at det er drap. ${ }^{34}$

${ }^{33}$ Hagens (2008: 118) eksempler.

${ }^{34}$ NRGs (1997: 391) eksempel. 
6. Det er også mulig at predikativet får et annet genus enn det substantivet har, men retter seg etter biologisk kjønn i stedet (constructio ad sensum) (Rønhovd 1993: 47):

Barnet er lei alt maset. ${ }^{35}$

\subsection{Adjektiver $\mathrm{i}$ adverbialfunksjonen og som adledd i AP}

Adjektiver brukt i adverbialfunksjonen og som adledd i AP-er har de samme formene som adjektiver som står til nøytrumssubstantiver, det vil si at de i de fleste tilfellene får en - $t$ endelse lagt til stammen. Modifikasjoner av og avvik fra denne regelen faller sammen med modifikasjonene og avvikene som gjelder nøytrumsformer (bl.a. manglende bøyning når adjektivstammen slutter på -ig, eller -e).

På grunn av sammenfall av adjektivformene i adverbialfunksjonen og i predikativ posisjon (når adjektivet står til et nøytrumssubstantiv), kan det av og til komme til tvetydigheter (som i setning 1 nedenfor), som ellers blir unngått når predikativet står til et maskulint eller feminint substantiv (jf. setningene 2 og 3 nedenfor). I slike tilfeller kan adjektivet tolkes som enten et subjekts- / objektspredikativ eller som et måtesadverbial (Lie 1979: 86):

1. Brudeparet svømte vakkert i bølgene. (vakkert: subjektspredikativ eller måtesadverbial)

2. Hun svømte vakkert i bølgene. (vakkert: måtesadverbial)

3. Hun svømte vakker i bølgene. (vakker: subjektspredikativ)

Selv om antallet adjektivendelser i bokmål ikke er stort, kan antallet regler for bøyning og bruk av de forskjellige formene virke komplisert. Dertil gjør den språklige situasjonen i Norge (to målformer, mangfold av dialekter, stadig språkendring)

${ }^{35}$ Rønhovds (1993: 47) eksempel. 
saken enda mer innviklet. I neste seksjon blir bøyning av adjektiver presentert fra det dialektale perspektivet.

\subsubsection{Samsvarsbøyning i norske målformer og dialekter}

\subsubsection{Bokmål og nynorsk}

I NRG (1997: 367) står det at det egentlig ikke finnes noen forskjeller mellom adjektivbøyning i bokmål og nynorsk, slik at bøyningen blir omtalt sammen i referansegrammatikken. Likevel kan man finne noen små forskjeller mellom målformene, for eksempel har nynorske adjektiver som slutter på -en, en sideform med $-i$ i hunkjønn, og $\mathrm{i}$ intetkjønn er endingen: - $e$ pluss to sideformer på $-i$ og -ent (Faarlund 1998: 84, Hagen 1998: 405, Venås 1990: 62):

Mask. Fem. Nøyt.

Sing. $\quad$ Sing. $\quad$ Sing. Pl.

ein open ei open [opi] eit opi/ope [opent] opne bilar, bil dør vindauge dører, vindauge

Dessuten har adjektiver med flere enn én konsonant før -en et valgfritt form på -ne eller -ene i nynorsk:

$\begin{array}{llll}\text { Mask. } & \text { Fem. } & \text { Nøyt. } & \\ \text { Sing. } & \text { Sing. } & \text { Sing. } & \text { Pl. } \\ \text { ein } \text { undren } & \text { ei undren } & \text { eit undri/undre } & \text { undrne/ menn, } \\ \text { mann } & \text { kvinne } & \text { barn } & \text { undrene kvinner, } \\ & & & \text { barn }\end{array}$

Det er også forskjeller i hvorvidt perfektum partisipper blir bøyd i de to målformene. Nynorske partisipper må samsvarsbøyes med substantivet de står til i predikativ stilling, mens i bokmål forblir perfektum partisipper ubøyd (NRG 1997: 343). Blant annet Faarlund (1998: 81-85) angir et omfattende bøyningsparadigme av perfektum partisipper, men siden 
partisipper ikke blir betraktet som adjektiver i denne oppgaven, blir de ikke omtalt bredere her.

\subsubsection{Dialektale forskjeller}

I ulike dialekter tas det hensyn til samsvarsbøyning på ulikt vis. Som Sandøy (1988: 85) hevder, er variasjonen størst i predikativ posisjon, men den er også til stedet i attributiv stilling. Her vil jeg nevne bare noen få av de eksisterende forskjellene mellom talemål og skriftspråk.

Vestlandske dialekter skiller seg tydelig ut av de resterende dialektene på grunn av deres ubestemte (dvs. sterke) adjektivog partisippform med -e-endelse. I Fjordane og Sunnmøre brukes det en innskuddsvokal i ubestemt form entall i hankjønn og hunnkjønn: æin store båt (Papazian \& Helleland 2012: 116). En omvendt situasjon finner sted i Salten i Nord-Norge der det ofte kommer til avhogging av endelsesvokal: «Vokalen i flertallsformene og bestemt form av adjektiv er også borte: $d i$ stor husan, den stor skåla, di størr og størst bedriftan. Avhogginga av endelsesvokalen i disse og andre ordformer har fort til at usammensatte ord i dialekten for en stor del er enstavede» (Vigeland 1981: 104).

Når det gjelder predikativ stilling, mangler både nordnorsk og bergensk flertallsendingen - $e$ når adjektivet står til et flertallssubjekt etter verbene: vere/verte/bli, for eksempel: Dei er stor og fin (Papazian \& Helleland 2012: 123, Vigeland 1995: 37). En omvendt situasjon finner sted i mange vestlandsmål der det ofte settes inn en innskuddsvokal i den bestemte hankjønns- og hunkjønnsformen av adjektiver og partisipper av svake verb, for eksempel: Han er sterke. Ho er dømde (Vigeland 1981: 89).

Dialektene er forskjellige ikke bare når det gjelder innskudd eller bortfall av endelsesvokal ved adjektiver i ulike bøyningskategorier, men også kan det i ulike dialekter brukes ulike endelsesvokaler i adjektivklassen. For eksempel brukes det $-a$-endelsen i pluralis femininum i flere vestlandsmål og midlandsmål og $\mathrm{i}$ bestemt form singularis femininum og 
nøytrum i sørvestlandske dialekter (Vigeland 1981: 167). Dessuten får adjektiver i entall intetkjønn ofte enten $-e$ eller $-i$ (eit kriste / kristi barn) i mange dialekter (ibid.). Sandøy (1988) nevner foruten flere mulige endelser som kan forekomme i predikativ posisjon i ulike kombinasjoner $(-i,-e,-n e,-a$, -en, -t, Ø) i enkelte dialekter $i$ hele Norge. Noen steder er det en total diskrepans mellom alle kjønnene og tallene (på Søre Sunnmøre), andre steder er det et totalt sammenfall av kjønnene og tallene (i noen av dialektene i Trøndelag og Nord-Norge), men også andre kombinasjoner er mulige, for eksempel sammenfall av former i hankjønn, hunkjønn og flertall og et opposisjonsform i nøytrum (i Hallingdal, i Nord-Aurdal og i Nord-Østerdalen), sammenfall av former i hunkjønn og intetkjønn og selvstendige former $\mathrm{i}$ hankjønn og flertall (VestTelemark) (ibid.). Det kan altså sies at dialektal variasjon i adjektivbøyning er ganske stor.

\subsubsection{Adjektivbøyning i polsk, engelsk og tysk}

\subsubsection{Adjektivbøyning i polsk}

Polske adjektiver må samsvarsbøyes med substantiver (og i visse tilfeller også med verb, noe som blir omtalt nedenfor) $i$ tre kategorier: numerus, genus og kasus $\mathrm{i}$ både attributiv og predikativ stilling. Hver av kategoriene består av flere trekk: Numerus har to trekk: singularis og pluralis, genus har fire trekk i entall: levende og ikke-levende maskulinum (L-Mask. og ILMask.), femininum (Fem.) og nøytrum (Nøyt.), og to trekk i flertall: maskulinum (Mask.) og ikke-maskulinum (I-Mask.), og kasus har seks trekk: nominativ (sammen med vokativ), genitiv, dativ, akkusativ, instrumentalis og lokativ. Slik Wróbel (2001: 124) påstår, er adjektivets funksjonsparadigme sterkt utbygget $\mathrm{i}$ polsk (for kategoriene kan kombineres på flere måter), men fordi det kommer til mange synkretismer, er dets formparadigme redusert, og består av kun 10-12 former, avhengig av bøyningstype. Wróbel (2001: 125-126) nevner ni bøyningstyper, likevel gjelder kun seks av dem adjektiver, mens de tre 
øvrige typene gjelder determinativer og pronomener. Tabell 4 viser bøyningsparadigmet til den første typen, som inneholder blant annet adjektivet dobry (god).

\begin{tabular}{|c|c|c|c|c|c|c|}
\hline \multicolumn{7}{|c|}{ Adjektiv } \\
\hline & \multicolumn{4}{|c|}{ singularis } & \multicolumn{2}{|c|}{ pluralis } \\
\hline Kasus & $\begin{array}{l}\text { L- } \\
\text { Mask. }\end{array}$ & $\begin{array}{l}\text { IL- } \\
\text { Mask }\end{array}$ & Fem. & Nøyt. & Mask. & $\begin{array}{l}\text { I- } \\
\text { Mask }\end{array}$ \\
\hline $\begin{array}{l}\text { nominativ } \\
\text { vokativ }\end{array}$ & $-y$ & $-y$ & $-\mathrm{a}$ & $-e$ & (rz)-y & $-e$ \\
\hline genitiv & -ego & -ego & - -ej & - -ego & $-\mathrm{ych}$ & $-y c h$ \\
\hline dativ & -emu & -emu & $-e j$ & -emu & $-\mathrm{ym}$ & $-\mathrm{ym}$ \\
\hline akkusativ & -ego & $-\mathrm{y}$ & $-a ̨$ & $-e$ & $-y c h$ & $-e$ \\
\hline instrumentalis & $-\mathrm{ym}$ & $-y m$ & $-a ̨$ & $-\mathrm{ym}$ & $-y m i$ & $-y m i$ \\
\hline lokativ & $-\mathrm{ym}$ & $-y m$ & $-e j$ & $-\mathrm{ym}$ & $-y c h$ & - -ych \\
\hline
\end{tabular}

Tabell 4: Fordeling av endelsene ved polske adjektiver

Bøyningsparadigmene til de andre bøyningstypene kan baseres på paradigmet fra Tabell 4, men inneholder modifikasjoner som har fonologisk grunnlag, for eksempel i den andre typen brukes det i maskulinum pluralis $-i$ istedenfor $-y$, noe som følgelig fører til palatalisering av adjektivets stamme (f.eks. i piękny - piękni (= pen - pene), Wróbel 2001: 127). Fordi bøyningsparadigmet er i grunnen det samme, vil jeg her ikke berøre alle mulige modifikasjoner og avvik fra regelen.

Det samme bøyningsparadigmet brukes i polsk når adjektivet står i attributiv og predikativ posisjon. Det er imidlertid en viktig forskjell mellom disse to posisjonene når det gjelder samsvarsbøyning. Attributter samsvarsbøyes med substantiver de står til (beskriver, klassifiserer) i alle de tre kategoriene polske adjektiver bøyes i, mens predikativer samsvarsbøyes med substantiver kun i to kategorier: tall og kjønn, og med verb i kasuskategorien. Ulike verb krever ulik kasus, noe som eksemplene 1-4 nedenfor illustrerer:

1. Chłopiec jest szczęśliwy. (SG, Mask., Nom.) Gutten er lykkelig. 
2. Dziewczynka jest szczęśliwa. (SG, Fem., Nom.) Jenta er lykkelig.

3. Uczynili chłopca szczęśliwym. (SG, Mask., Instr.)

De har gjort gutten lykkelig.

4. Uczynili dziewczynkę szczęśliwą. (SG, Fem., Instr.)

De har gjort jenta lykkelig.

Å lage adverb av adjektiver kalles i polsk lingvistikk for derivasjon (Wróbel 2001: 205), og ikke bøyning, slik det oftest er tilfellet i norsk lingvistikk. Det er tre derivater som kan lage adverb av adjektiver: to suffikser: $-e$ og $-o$, og en kombinasjon av en separert prefiks samt suffiks: po... -u. Eksemplene 5-7 nedenfor illustrerer bruken av derivatene:

5. norweski-po norwesku (norsk - norsk)

6. bezczelny - bezczelnie (frekk - frekt)

7. mity - mito (snill - snilt)

Ettersom syntaktiske og semantiske egenskaper ved polske adjektiver ikke skiller seg fra de norske, vil de ikke bli omtalt i denne avhandlingen.

\subsubsection{Adjektivbøyning i engelsk}

Adjektiver i engelsk blir bøyd i kongruens verken i attributiv eller i predikativ stilling. Den eneste typen bøyning de engelske adjektivene har, er adverbialbøyning (gradbøyning finnes også i engelsk, men denne typen adjektivbøyning blir ikke behandlet i denne oppgaven). Det er egentlig vanskelig å si om adverbialbøyning i engelsk høres til fleksjonsbøyning eller derivasjon, men siden det $\mathrm{i}$ grunnen er snakk om navnet på en og samme prosess, kan man godt kalle den for derivasjon $\mathrm{i}$ operasjonsdefinisjonen her. Det er bare én endelse de engelske adjektivene han få for å kunne fungere adverbialt: -ly, som i bitter-bitterly (bitter-bittert). Det er tross alt en del adjektiver som har samme form i adjektivisk (dvs. attributiv og predikativ bruk) og adverbiell bruk, for eksempel: fast (rask), late (sen) og 
early (tidlig), daily (daglig). Noen adverb kan ha ulik betydning, avhengig av om de får -ly-endelsen eller ikke, for eksempel: late (sen), lately (nylig).

Som i tilfellet polsk, er de syntaktiske og semantiske egenskapene ved engelske adjektiver ikke forskjellige fra de norske, og derfor blir de ikke behandlet her.

\subsubsection{Adjektivbøyning i tysk}

Tyske adjektiver kan synes å ha den mest vanskelige bøyningen blant språkene omtalt her siden de må obligatorisk bøyes i fire kategorier: numerus, genus, kasus og bestemthet. Imidlertid gjelder bøyningen bare adjektivets attributive funksjon. Predikativer og adjektiviske adverbialer forblir ubøyd i tysk. Hver av de fire kategoriene de tyske attributter bøyes i, har flere trekk. Numerus har to trekk: singularis og pluralis, genus har tre trekk: maskulinum, femininum og nøytrum, kasus har fire trekk: nominativ, genitiv, dativ og akkusativ, og bestemthet har tre trekk - det skilles mellom ubestemte, bestemte og nakne former. Det er vanlig å snakke om sterke og svake adjektivformer. De sterke formene brukes foran substantiver som forekommer uten artikler (i naken form), og det er do typer svake bøyninger: de ene kommer etter artikler i bestemt form (f.eks. dieser $=$ denne), og de andre - etter artikler i ubestemt form $($ f.eks. kein $=$ ingen). Den siste typen bøyning er egentlig en kombinasjon av de to første typene. Funksjonsparadigmet er svært utbygget som konsekvens av det store tallet kategorier og trekk, men som i tilfellet polsk, oppstår det mange synkretismer, slik at det egentlig er snakk om kun fem ulike endelser i tysk adjektivbøyning. Tabell 5Tabell 6Tabell 7 nedenfor viser alle de ovenfornevnte typene bøyning i tysk (hentet fra Duden 2005: 368-369). 


\begin{tabular}{|l|l|l|l|l|}
\hline \multicolumn{5}{|c|}{ Adjektiv } \\
\hline \multicolumn{5}{|c|}{ singularis } \\
\hline Kasus & Mask. & Fem. & Nøyt. & \\
\hline nominativ & kalter Rauch & kalte Milch & kaltes Wasser & kalte Sachen \\
\hline genitiv & kalten Rauchs & kalter Milch & kalten Wasser & kalter Sachen \\
\hline dativ & kaltem Rauch & kalter Milch & kaltem Wasser & kalten Sachen \\
\hline akkusativ & kalten Rauch & kalte Milch & kaltes Wasser & kalte Sachen \\
\hline
\end{tabular}

Tabell 5: Sterk adjektivbøyning i tysk

\begin{tabular}{|l|l|l|l|c|}
\hline \multicolumn{5}{|c|}{ Adjektiv } \\
\hline \multicolumn{3}{|c|}{ singularis } & pluralis \\
\hline Kasus & Mask. & Fem. & Nøyt. & \\
\hline nominativ & kalte Rauch & kalte Milch & kalte Wasser & kalten Sachen \\
\hline genitiv & kalten Rauchs & kalten Milch & kalten Wassers & kalten Sachen \\
\hline dativ & kalten Rauch & kalten Milch & kalten Wasser & kalten Sachen \\
\hline akkusativ & kalten Rauch & kalte Milch & kalte Wasser & kalten Sachen \\
\hline
\end{tabular}

Tabell 6: Svak adjektivbøyning i tysk - etter bestemte artikler

\begin{tabular}{|l|l|l|l|c|}
\hline \multicolumn{5}{|c|}{ Adjektiv } \\
\hline & \multicolumn{3}{|c|}{ singularis } & pluralis \\
\hline Kasus & Mask. & Fem. & Nøyt. & \\
\hline nominativ & kalter Rauch & kalte Milch & kaltes Wasser & kalten Sachen \\
\hline genitiv & kalten Rauchs & kalten Milch & kalten Wassers & kalten Sachen \\
\hline dativ & kalten Rauch & kalten Milch & kalten Wasser & kalten Sachen \\
\hline akkusativ & kalten Rauch & kalte Milch & kaltes Wasser & kalten Sachen \\
\hline
\end{tabular}

Tabell 7: Svak adjektivbøyning i tysk - etter ubestemte artikler

\subsubsection{Sammenlikning med norsk}

Når en sammenlikner adjektivbøyning i norsk med adjektivbøyning i polsk, engelsk og tysk, ser man at selve systemet er mest lik mellom norsk og polsk. I begge språkene bøyes adjektiver både i attributiv og i predikativ stilling. Det finnes også adverbialbøyning av adjektiver der. Både i norsk og polsk blir adjektiver samsvarsbøyd i tre kategorier: tall og kjønn 
er felles for begge språkene, i tillegg har norsk bestemthetsbøyning, og polsk - kasusbøyning. Systemet i engelsk og tysk er ulike i forhold til hverandre, og ulike i forhold til norsk og polsk, men på forskjellige måter. Engelsk mangler samsvarsbøyning i det hele tatt, og har bare adverbialbøyning, mens tysk har bare samsvarsbøyning av attributter, og mangler samsvarsbøyning av predikativer og adverbialbøyning. Tabell 8 illustrerer likhetene og forskjellene mellom språkene.

\begin{tabular}{|c|c|c|c|c|c|}
\hline & type bøyning & norsk & polsk & engelsk & tysk \\
\hline \multirow{2}{*}{ 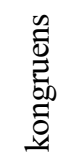 } & attributiv stilling & V & V & $\mathrm{X}$ & $\mathrm{V}$ \\
\hline & predikativ stilling & V & V & $\mathrm{X}$ & $\mathrm{X}$ \\
\hline & adverbialbøyning & V & V & V & $\mathrm{X}$ \\
\hline
\end{tabular}

Tabell 8: Typer adjektivbøyning i norsk, polsk, engelsk og tysk $(V=$ tilstedeverelse av egenskapet, $X$ = fravcer av egenskapet)

\subsubsection{Oppsummering}

I dette underkapittelet har jeg presentert semantiske, syntaktiske og morfologiske egenskaper ved adjektiver. Det har blir vist hvordan adjektiver kan deles på semantisk grunnlag. Hovedfokuset har imidlertid blitt lagt på hvordan adjektiver oppfører seg i setningen, det vil si hvordan de danner fraser, og hvordan disse frasene kan fungere i setningen. Det er også blitt gitt en omfattende oversikt over adjektivets morfologi der både hovedregelen, dens modifikasjoner og avvik fra den er blitt presentert. Jeg har for øvrig vist i hvilke kontekster skal hver av adjektivets former brukes. Senere har det blitt diskutert variasjon $\mathrm{i}$ adjektivbøyningen mellom de to norske skriftnormene: bokmål og nynorsk, og blant talemål. Det viser seg at selv om hovedregelen for adjektivbøyning i bokmål (og også i 
nynorsk) er relativt enkel, så er antallet modifikasjoner av og avvik fra den stort. I tillegg er antallet regler for bruk av formene også ganske stort. Dialektal variasjon øker kompleksiteten av bruken av adjektivbøyningen, noe som kan ha konsekvenser for tilegnelse av den norske adjektivbøyningen av andrespråksinnlærere. Til slutt har jeg presentert hvordan adjektiver bøyes i polsk, engelsk og tysk, og sammenliknet bøyningssystemene $\mathrm{i}$ disse språkene med bøyningssystemet $\mathrm{i}$ norsk. En slik sammenlikning viser at den polske adjektivbøyningen er mest likt den norske, mens den engelske og tyske er forskjellige både fra hverandre, og fra polsk og norsk. 


\section{Metode}

I dette kapittelet vil jeg presentere måten jeg har fått tak i dataene til analysen på, og hvordan disse dataene er behandlet $\mathrm{i}$ analysen. Metoder anvendt i denne oppgaven er både av kvantitativt (statistisk) og kvalitativt slag, og de kvantitative metodene skriver seg inn i korpuslingvistikken. Det første underkapittelet gjør rede for korpuslingvistikken som en metode innen lingvistikkdisiplinen. Underkapittel nummer to presenterer innlærerkorpuset ASK hvor datamateriale i analysen kommer fra. Det er forklart hva korpuset inneholder, hvordan det er bygget opp, hva slags informasjon det inneholder, og hvordan dataene er inkorporert og bearbeidet $\mathrm{i}$ korpuset. Videre gis det en kort beskrivelse av informantene hvis tekster befinner seg i korpuset. Underkapittelet slutter med rapporten om hvordan dataene er blitt forberedt før analysen. Det forklares for øvrig hvilke data som (ikke) ble tatt med i analysen. I det tredje underkapittelet er det giort greie for hvilke statistiske tester som er brukt i analysen, hvordan de fungerer, og hvor i analysen de er brukt. Underkapittel nummer fire tar for seg metoden som er brukt i transferanalysen. Det femte underkapittelet vil vise hvilke forskningsspørsmål vil jeg svare på ved hjelp av den kvalitative analysen, og det siste underkapitlet redegjør for hvilke begrensninger metodene jeg bruker, har.

\subsection{Korpuslingvistikk}

I min studie bygger den kvantitative analysen i sin helhet på korpuslingvistikk som generelt sett er omtalt som en metode innen lingvistikkdisiplinen, og ikke som en av dens grener:

Corpus linguistics can best be defined as a linguistic methodology which is founded on the use of electronic collections of naturally occurring texts, viz. corpora. It is neither a new branch of linguistics nor a new theory of language, but the very nature of the 
evidence it uses makes it a particularly powerful methodology, one which has the potential to change perspectives on language. (Granger 2002: 1)

Den er blitt mye brukt først og fremst på grunn av muligheten den gir til å behandle store datasett (som egentlig er umulig å behandle av enkeltmennesker), deres feilfrihet og raskhet (noe som ikke alltid er oppnåelig i manuelt arbeid), og generaliseringsmuligheter ettersom korpusdata kan testes statistisk (McEnery \& Hardie 2012: 2).

Korpuslingvistikk beror på å bruke elektroniske korpuser, i motsetning til vanlige datasamlinger, også ofte omtalt som korpuser, men som stort sett bygger på manuelt arbeid utført av enkeltpersoner (Tenfjord, Hagen \& Johansen 2009: 54). I andrespråkslæring brukes såkalte andrespråkskorpuser eller innloererkorpuser (eng. second language learner corpora) som er definert av Sinclair (1996) på følgende måte:

Computer learner corpora are electronic collections of authentic $\mathrm{FL} / \mathrm{SL}^{36}$ textual data assembled according to explicit design criteria for a particular SLA/FLT ${ }^{37}$ purpose. They are encoded in a standardised and homogeneous way and documented as to their origin and provenance. (Sinclair 1996, referert i: Granger 2002: 4)

Bruken av innlærerkorpuser i andrespråkslæring har ført til at det har oppstått en avgrening i korpuslingvistikk-metodologien - innlcererkorpusforskning (eng. learner corpus research) som har de samme fordelene som korpuslingvistikk har. Det har allerede oppstått flere typer innlærerkorpuser som ifølge Granger varierer når det gjelder:

1) Time of collection (cross-sectional, longitudinal and quasilongitudinal language corpora);

2) Scope of collection (global and local learner corpora);

3) Targeted language (L2);

${ }^{36}$ Foreign Language / Second Language.

${ }^{37}$ Second Language Acquisition / Foreign Language Teaching. 
4) Learner's mother tongue (L1);

5) Medium (written, spoken and multimedia learner corpora);

6) Text type (argumentative essays, informal interviews and other).

Granger (2012: 11-12)

Som Granger påpeker, består innlærerkorpusforskning vanligvis av sju steg, hvorav fem er obligatoriske, mens de to resterende som oftest også er anvendt, men som ikke er obligatoriske (de er skrevet i kursiv):

1) Choice of methodological approach;

2) Selecting and/or compilation of learner corpus;

3) Data annotation;

4) Data extraction;

5) Data analysis;

6) Data interpretation;

7) Pedagogical implementation.

Granger (2012: 13)

Det er to konkurrerende metodologiske tilnærminger som er gjeldene i korpuslingvistikken: korpus-baserte studier (eng. corpus-based studies) hvor man bruker korpus som metodologi for å bekrefte hypoteser satt tidligere, og korpus-drevne studier (eng. corpus-driven studies) hvor det nettopp er korpuset som er kilde til hypoteser om språk (McEnery \& Hardie 2012: 6). Når det gjelder dataannotasjon, er det ikke alle korpuser som bruker det, men mange korpuser er tagget med automatiske taggere, og Granger påstår at:

Fortunately some of the most reliable and widely available corpus tools are part-of-speech (POS) taggers, which automatically assign a word category to every word in the corpus with an accuracy rate that can reach $98 \%$. (Granger 2012: 14)

Det er dessuten vanlig med annotering av avvik fra målspråksnormen, det vil si med feilkoding i innlærerkorpuser. Det er imidlertid en ting blant annet Bley-Vroman (1983) advarer mot når det gjelder feilkoding. Han kaller det for 
The Comparative Fallacy (sammenlikningsfella). Han påstår at med å feilkode innlærertekster, undervurderer man på en måte mellomspråk med at man betrakter dem som feilversjoner eller avvik fra målspråksnormen: «work on the linguistic description of learner's languages can be seriously hindered or sidetracked by a concern with the target language» (Bley-Vroman 1983: 2). $\mathrm{Og}$ da undervurderer man mellomspråk som selvstendige språksystemer, noe som både er i strid med andrespråkslæringsteorien, og med selve ideen av mellomspråket. Blay-Vroman argumenterer for at «the learner's system is worthy of study in its own right, not just as a degenerate form of the target system» (ibid.: 4).

White påstår imidlertid at det å sammenligne S2- og S1brukere av samme språk er i mange tilfeller ønskelig ettersom:

There are legitimate reasons for asking whether the L2 learner has in fact acquired properties of the L2. After all, the learner is exposed to L2 input in some form, and the L2 is a natural language. (White 2003: 27)

Tenfjord, Hagen og Johansen gir for øvrig argumenter for tross alt å bruke feilkoding i innlærerkorpuser og påstår at «det å kode en tekst for feil i seg selv ikke er å gå i en slik sammenlikningsfelle som Bley-Vroman med rette advarer mot» (Tenfjord, Hagen \& Johansen 2009: 53). De mener at man må skille mellom analytiske informasjoner, som er oppnåelig gjennom et innlærerkorpus, og teoretiske informasjoner, som man konstruerer for å forklare fenomenene funnet i korpuset. Man må med andre ord ikke forveksle analytiske verktøy med teori, ifølge dem:

Det er ikke slik at det å registrere og kategorisere feil nødvendigvis forutsetter en teori som søker innsikt i andrespråkskompetanse ved hjelp av å systematisk beskrive andrespråksperformansen gjennom målspråkets strukturelle kategorier alene, eller som kategoriserer et andrespråktrekk som noe som samsvarer eller avviker fra målspråket. (Tenfjord, Hagen \& Johansen 2009: 58) 


\subsection{Datamaterialet \\ 4.2.1 ASK-korpuset}

I min analyse benytter jeg et innlærerkorpus - Norsk andrespråkskorpus (fork. ASK-korpuset, eller bare ASK). ASK er et elektronisk innlærerkorpus som ble ferdigstilt i 2006 ved Universitet i Bergen, og er blitt videreutviklet av forskergruppe ASKeladden ved det samme universitetet. ASK som helhet består av tre underkorpuser: hovedkorpuset, korrektkorpuset, og kontrollkorpuset (kilde: ASKeladden). Hovedkorpuset inneholder tekster skrevet i en testsituasjon av morsmålsbrukere av ti ulike morsmål (albansk, engelsk, nederlandsk, polsk, russisk, serbokroatisk, somali, spansk, tysk, vietnamesisk) på to testnivåer: Språkprøven i norsk for voksne innvandrere (som måler norskkunnskaper på B1-nivå ${ }^{38}$ ) og Test $i$ norsk - høyere nivå, også kalt Bergenstesten (som måler norskkunnskaper på B2-nivå) $)^{39}$. Hver informant har produsert én tekst, og det er 200 tekster fra hver morsmålsgruppe, 100 på hvert av de to testnivåene (det er imidlertid tre unntak fra dette: det er færre tekster på Høyere nivå produsert av morsmålsbrukere av somali, vietnamesisk og albansk ettersom det viste seg å være umulig å finne flere informanter med disse morsmålsbakgrunnene på det nivået). Det er altså litt færre enn 2000 tekster (og testtakere) til sammen. Grunnen til at det skulle være 100 tekster fra hver morsmålsgruppe på hvert nivå, var av metodologisk slag: «We decided that, in order to have enough data for statistical analysis of L1 influence on SLA, we need to have 100 texts written by learners of the same L1» (Tenfjord 2004: 151). Fordelen med at testene i ASK er på to nivåer, er at det blir så mulig å gjennomføre pseudo-longitudinelle studier.

38 I samsvar med Det felles europeiske rammeverket for språk (eng. Common European Framework of Reference for Languages: Learning, teaching, assessment, fork. CEFR), bredere omtalt i kapittelet Teoretisk tilnærming, underkapittelet: Sosiale faktorer.

39 Begge testene er rettet mot voksne innvandrere i Norge, men også personer som ikke har flyttet til Norge for bestandig kan ta testene (Vox, Folkeskole). 
Denne metoden kombinerer ifølge Jarvis og Pavlenko (2008: 36) longitudinelle metoder med tverrsnittstudier, og tar fram det beste fra begge - forskeren kan undersøke like mange informanter som i tverrsnittstudier og gjøre det like grundig som i longitudinelle studier. Man kan derfor observere hvordan kunnskapen om språket utvikler seg hos språkbrukere selv om man ikke observerer en og samme språkbruker over lengre tid.

Tekstene er ekte svar på de to ovenfor omtalte norsktestene, og kommer bare fra informantenes prestasjoner som er blitt godkjent, det vil si bedømt bestått (Tenfjord, Hagen \& Johansen 2009: 56). Bestått-kriteriet er ett av de tre kriteriene som alle tekstene i ASK-korpuset måtte oppfylle. De to resterende kriteriene er: morsmålskriteriet (informantenes morsmål viser en typologisk variasjon - de hører til flere språkfamilier), og info-kriteriet (det finnes personopplysninger om hver av informantene). Som sagt ovenfor, er feilkoding anvendt til innlærertekstene i ASK, og til hver feil en korrekt struktur er foreslått. På basis av disse korreksjonene har et korrektkorpus blitt generert. I tillegg til innlærernes besvarelser, som utgjør hovedkorpuset, og korrektkorpuset er det i ASK også et kontrollkorpus som består av tekster skrevet av personer med norsk som morsmål. Dette korpuset er imidlertid forskjellig fra hovedkorpuset $i$ at besvarelsene ikke har oppstått $i$ en testsituasjon (ibid.: 55).

Informantenes tekster i korpuset er tilgjengelige enten som 'rå tekst' (eng. raw text), noe som oppfyller den forste av Leech's sju maksimer for annotering av korpus (Leech's Maxims of Annotation), og som er formulert slik: «It should be possible to remove the annotation from an annotated corpus in order to revert to the raw corpus» (Leech 1993, hentet fra Tenfjord, Hagen \& Johansen 2009: 71), eller med annotasjoner. Ordklassene, en del morfologi og syntaks er automatisk tagget med Oslo-Bergen-taggeren som er utviklet ved Universitetet i Oslo og Uni Computing i Bergen (Golden \& Tenfjord 2014: 6). De automatiske taggene har blitt etterprøvd manuelt. Feilkoding 
er i sin helhet gjennomført manuelt av sensorer med den samme type instruksjon og opplæring (ibid.: 55).

I ASK kan man velge attributter man vil søke etter. Det kan velges blant: tekst-id (som samtidig er informant-id siden én tekst var skrevet av nøyaktig én informant), morsmål, språktest, CEFR-nivå, tema, oppgavetittel. Blant språklige trekk kan man velge: ordklasse, morfologiske og syntaktiske trekk, feiltype, undertype, korreksjon, setnings-id, XML-sti, annotasjon, error-annotasjon. Hver av disse har også undertyper, noe som gir et svært bredt utvalgsspekter. Korpuset gir mulighet til å søke etter ord og lemma. Hvert søk kan stilles slik som det best passer til problemet man vil undersøke fordi man selv kan legge til attributter man leter etter. På den måten kan man både søke i en gitt (eller flere) morsmålsgruppe, på ett eller begge testnivåer, og avgrense søket til en gitt (eller flere) språkstrukturer.

Korpuset inneholder i tillegg personopplysninger om deltakerne som også kan søkes etter. Blant disse kan man søke etter: norskopplæring / bruk (nivå, sosial omgang, kursmål / motivasjon, type norskkurs, kurstimer, tid siden kursstart), bruk av norsk (hyppighet, i fritid / på jobb), persondata (oppholdstid i Norge, yrke, sysselsetting i Norge, utdanning, kjønn, alder, hjemland) og engelskferdigheter. Søkemuligheter i ASK gjør det mulig å søke på flere variabler samtidig.

\subsubsection{Informanter - innlærervariabler}

I undersøkelsen analyserer jeg ytringene til de polskspråklige informantene. Fordi transferundersøkelsen imidlertid utgjør en sammenligning av de polskspråkliges ytringer med ytringene til de engelsk- og tyskspråklige, vil jeg presentere alle informantene på dette punktet. Jeg har analysert 200 tekster fra hver av de tre morsmålsgruppene, det vil si 600 tekster til sammen. Hver av tekstene er blitt skrevet av kun én person, det betyr at jeg har tatt $\mathrm{i}$ analysen tekster skrevet av 600 ulike individer. Ettersom ASK-korpuset gir personopplysninger om 
alle deltakerne, er det mulig å gi en nokså grundig presentasjon av dem.

Gjennomsnittlig er informantene 31 år gamle (median 29 år). Den yngste er 17, og den eldste 63 år gammel. Tabell 9 viser aldrene i hver av S1-gruppene.

\begin{tabular}{|l|l|l|l|l|}
\hline S1 & polsk & engelsk & tysk & alle \\
\hline gjennomsnitt & 31 & 33 & 29 & 31 \\
\hline median & 29 & 32 & 28 & 29 \\
\hline min. verdi & 19 & 17 & 17 & 17 \\
\hline maks. verdi & 54 & 63 & 61 & 63 \\
\hline
\end{tabular}

Tabell 9: Informantenes alder

De fleste informantene er kvinner (79\%), og her skiller den polske S1-gruppen seg ut med færrest menn -12 . Tabell 10 viser kjønnsfordeling i hver av morsmålsgruppene. I den polskspråklige gruppen er det en person med ukjent kjønn.

\begin{tabular}{|l|l|l|l|l|}
\hline S1 & polsk & engelsk & tysk & alle \\
\hline \multirow{2}{*}{ kvinne } & 187 & 133 & 155 & 475 \\
& $(94 \%)$ & $(67 \%)$ & $(78 \%)$ & $(79 \%)$ \\
\hline \multirow{2}{*}{ mann } & 12 & 67 & 45 & 124 \\
& $(6 \%)$ & $(34 \%)$ & $(23 \%)$ & $(21 \%)$ \\
\hline
\end{tabular}

Tabell 10: Informantenes kjønn

$91 \%$ av informantene har fått enten videregående utdanning eller høyere. Nesten to tredjedeler er høyere utdannet. I Tabell 11 er det presentert testtakernes utdanningsnivå. 


\begin{tabular}{|l|l|l|l|l|}
\hline S1 & polsk & engelsk & tysk & alle \\
\hline grunnskole & 0 & $\begin{array}{l}1 \\
(0,5 \%)\end{array}$ & $\begin{array}{l}3 \\
(1,5 \%)\end{array}$ & $\begin{array}{l}4 \\
(1 \%)\end{array}$ \\
\hline \multirow{2}{*}{ videregående } & $\begin{array}{l}10 \\
(20 \%)\end{array}$ & $\begin{array}{l}41 \\
(20,5 \%)\end{array}$ & $\begin{array}{l}80 \\
(40 \%)\end{array}$ & $\begin{array}{l}161 \\
(27 \%)\end{array}$ \\
\hline \multirow{2}{*}{ høyere utdan. } & $\begin{array}{l}158 \\
(79 \%)\end{array}$ & $\begin{array}{l}142 \\
(71 \%)\end{array}$ & $\begin{array}{l}86 \\
(43 \%)\end{array}$ & $\begin{array}{l}386 \\
(64 \%)\end{array}$ \\
\hline \multirow{2}{*}{ ukjent } & 2 & 16 & 31 & 49 \\
& $(1 \%)$ & $(8 \%)$ & $(15,5 \%)$ & $(8 \%)$ \\
\hline
\end{tabular}

Tabell 11: Informantenes utdanning

Deltakerne har tatt prøven gjennomsnittlig etter 1,5 år opphold i Norge. De har bodd i landet fra mindre enn ett år til lenger enn fem år. Tabell 12 viser informantenes oppholdstid $\mathrm{i}$ Norge før de har tatt prøven. Det kan legges merke til at den tyske S1-gruppen skiller seg ut her slik at det tok den minst tid før deltakerne har tatt prøven (ca. ett år mindre i forhold til de to øvrige gruppene).

\begin{tabular}{|l|l|l|l|l|}
\hline S1 & polsk & engelsk & tysk & alle \\
\hline \multirow{2}{*}{$0-1$ år } & $\begin{array}{l}67 \\
(33,5 \%)\end{array}$ & $\begin{array}{l}40 \\
(20 \%)\end{array}$ & $\begin{array}{l}123 \\
(61,5 \%)\end{array}$ & $\begin{array}{l}230 \\
(38 \%)\end{array}$ \\
\hline \multirow{2}{*}{$1-2$ år } & $\begin{array}{l}67 \\
(33,5 \%)\end{array}$ & $\begin{array}{l}68 \\
(34 \%)\end{array}$ & $\begin{array}{l}48 \\
(24 \%)\end{array}$ & $\begin{array}{l}183 \\
(31 \%)\end{array}$ \\
\hline \multirow{2}{*}{$2-3$ år } & $\begin{array}{l}17 \\
(8,5 \%)\end{array}$ & $\begin{array}{l}30 \\
(15 \%)\end{array}$ & $\begin{array}{l}14 \\
(7 \%)\end{array}$ & $\begin{array}{l}61 \\
(10 \%)\end{array}$ \\
\hline \multirow{2}{*}{$3-4$ år } & 7 & 13 & 4 & 24 \\
& $(3,5 \%)$ & $(6,5 \%)$ & $(2 \%)$ & $(4 \%)$ \\
\hline $4-5$ år & $\begin{array}{l}16 \\
(2,5 \%)\end{array}$ & $\begin{array}{l}1 \\
(8 \%)\end{array}$ & $\begin{array}{l}22 \\
(0,5 \%)\end{array}$ & $(4 \%)$ \\
\hline \multirow{2}{*}{ over 5 år } & $\begin{array}{l}32 \\
(16 \%)\end{array}$ & $\begin{array}{l}32 \\
(16 \%)\end{array}$ & $\begin{array}{l}73 \\
(4,5 \%)\end{array}$ & $(12 \%)$ \\
\hline \multirow{2}{*}{ ukjent } & $\begin{array}{l}5 \\
(2,5 \%)\end{array}$ & $\begin{array}{l}1 \\
(0,5 \%)\end{array}$ & $\begin{array}{l}1 \\
(0,5 \%)\end{array}$ & $\begin{array}{l}7 \\
(1 \%)\end{array}$ \\
\hline gjennomsnitt & 2,0 år & 2,4 år & 1,2 år & 1,8 år \\
\hline median & 1,5 år & 1,5 år & 0,5 år & 1,5 år \\
\hline
\end{tabular}

Tabell 12: Informantenes oppholdstid i Norge 
I ASK-korpuset er det også oppgitt informasjon angående antall kurstimer tatt av innlærerne før de har tatt prøven. Slike opplysninger gjelder imidlertid bare dem som har tatt Språkprøven, og ikke Bergenstesten, det vil si halvparten av deltakerne (300 personer, 100 i hver S1-gruppe) hvorav ikke alle har oppgitt informasjon om antallet norsktimer. Tabell 13 viser antallet norsktimer tatt av informantene som har tatt Språkprøven. Også denne gangen skiller den tyske S1-gruppen seg med færrest kurstimer tatt før eksamenen.

\begin{tabular}{|l|l|l|l|l|}
\hline S1 & polsk & engelsk & tysk & alle \\
\hline $0-200$ timer & 7 & 18 & 30 & $\begin{array}{l}55 \\
(18 \%)\end{array}$ \\
\hline $201-400$ timer & 40 & 29 & 35 & $\begin{array}{l}104 \\
(35 \%)\end{array}$ \\
\hline $401-500$ timer & 16 & 10 & 10 & $\begin{array}{l}36 \\
(12 \%)\end{array}$ \\
\hline $501-850$ timer & 25 & 33 & 8 & $\begin{array}{l}66 \\
(22 \%)\end{array}$ \\
\hline $851-1500$ timer & 2 & 2 & 0 & $\begin{array}{l}4 \\
(1 \%)\end{array}$ \\
\hline ukjent & 10 & 8 & 17 & $\begin{array}{l}35 \\
(12 \%)\end{array}$ \\
\hline gjennomsnitt & 434 timer & 430 timer & 282 timer & 385 timer \\
\hline median & 300 timer & 300 timer & 300 timer & 300 timer \\
\hline
\end{tabular}

Tabell 13: Antall kurstimer i norsk informantene har tatt før Språkprøven

Fordi informantenes stiler har blitt lest på nytt og revurdert i forhold til CEFR-nivåer, kan de også sammenlignes på dette grunnlaget. I vurderingen har også mellomnivåer blitt brukt, dvs. nivå A2/B1, B1/B2, B2/C1. Generelt sett er testene informantene skrev, mellom $\mathrm{A} 2$ og $\mathrm{C} 1$ nivå. De fleste $(79 \%)$ er på $\mathrm{B} 1, \mathrm{~B} 1 / \mathrm{B} 2$ og B2 nivå, det vil si de nivåene Språkprøven og Bergenstesten egentlig måler. Bare mindre enn $5 \%$ av deltakerne er på A 2 og C1 nivå. Tabell 14 viser antallet personer på hvert av nivåene i hver morsmålsgruppe. 


\begin{tabular}{|l|l|l|l|l|}
\hline S1 & polsk & engelsk & tysk & alle \\
\hline A2 & $2(1 \%)$ & $\begin{array}{l}2 \\
(1 \%)\end{array}$ & $\begin{array}{l}3 \\
(1,5 \%)\end{array}$ & $\begin{array}{l}7 \\
(1 \%)\end{array}$ \\
\hline \multirow{2}{*}{ A2/B1 } & $\begin{array}{l}25 \\
(12,5 \%)\end{array}$ & $\begin{array}{l}19 \\
(9,5 \%)\end{array}$ & $\begin{array}{l}8 \\
(4 \%)\end{array}$ & $\begin{array}{l}52 \\
(9 \%)\end{array}$ \\
\hline \multirow{2}{*}{ B1 } & 42 & 61 & 45 & 148 \\
& $(21 \%)$ & $(30,5 \%)$ & $(22,5 \%)$ & $(25 \%)$ \\
\hline \multirow{2}{*}{ B1/B2 } & 52 & 29 & 46 & 127 \\
& $(26 \%)$ & $(14,5 \%)$ & $(23 \%)$ & $(21 \%)$ \\
\hline B2 & $\begin{array}{l}58 \\
(29 \%)\end{array}$ & $\begin{array}{l}69 \\
(34,5 \%)\end{array}$ & $\begin{array}{l}70 \\
(35 \%)\end{array}$ & $\begin{array}{l}197 \\
(33 \%)\end{array}$ \\
\hline \multirow{2}{*}{ B2/C1 } & $\begin{array}{l}16 \\
(8 \%)\end{array}$ & $\begin{array}{l}23 \\
(6,5 \%)\end{array}$ & $\begin{array}{l}52 \\
(11,5 \%)\end{array}$ \\
\hline \multirow{2}{*}{ C1 } & $\begin{array}{l}7 \%) \\
(2,5 \%)\end{array}$ & $\begin{array}{l}7 \\
(3,5 \%)\end{array}$ & $\begin{array}{l}5 \\
(2,5 \%)\end{array}$ & $\begin{array}{l}17 \\
(3 \%)\end{array}$ \\
\hline median & $\mathrm{B} 1 / \mathrm{B} 2$ & $\mathrm{~B} 1 / \mathrm{B} 2$ & $\mathrm{~B} 1 / \mathrm{B} 2$ & $\mathrm{~B} 1 / \mathrm{B} 2$ \\
\hline
\end{tabular}

Tabell 14: Vurdering av informantenes tekster ved hjelp av CEFR-nivåer

Som Tabell 15 viser, bruker de fleste informantene (78 \%) norsk hver dag, noe som også gir bevis på at de er andrespråksinnlærere, og ikke fremmedspråksinnlærere. Bare $1 \%$ av informantene bruker norsk aldri, og alle de kommer fra den polske S1-gruppen. De resterende snakker norsk sjelden.

\begin{tabular}{|l|l|l|l|l|}
\hline S1 & polsk & engelsk & tysk & alle \\
\hline \multirow{2}{*}{ aldri } & $\begin{array}{l}5 \\
(2,5 \%)\end{array}$ & 0 & 0 & $\begin{array}{l}5 \\
(1 \%)\end{array}$ \\
\hline \multirow{2}{*}{ sjelden } & $\begin{array}{l}26 \\
(13 \%)\end{array}$ & $\begin{array}{l}37 \\
(18,5 \%)\end{array}$ & $\begin{array}{l}24 \\
(12 \%)\end{array}$ & $\begin{array}{l}87 \\
(15 \%)\end{array}$ \\
\hline \multirow{2}{*}{ daglig } & $\begin{array}{l}133 \\
(66,5 \%)\end{array}$ & $\begin{array}{l}158 \\
(79 \%)\end{array}$ & $\begin{array}{l}174 \\
(87 \%)\end{array}$ & $\begin{array}{l}465 \\
(78 \%)\end{array}$ \\
\hline \multirow{2}{*}{ ukjent } & $\begin{array}{l}36 \%) \\
(18 \%)\end{array}$ & $\begin{array}{l}5 \\
(2,5 \%)\end{array}$ & $\begin{array}{l}2 \\
(1 \%)\end{array}$ & $\begin{array}{l}43 \\
(7 \%)\end{array}$ \\
\hline
\end{tabular}

Tabell 15: Informantenes norskbruk 
Norskinnlærerne som har tatt prøven, vil enten søke arbeid eller opptak på skole i Norge ( $48 \%$ av svarene $)^{40}$, eller trenger å dokumentere sine norskkunnskaper (48\% av svarene), som trolig også vil hjelpe dem å søke arbeid eller opptak på skole. Tabell 16 viser informantenes motivasjon og mål med å ta kurset.

\begin{tabular}{|l|l|l|l|l|}
\hline S1 & polsk & engelsk & tysk & $\begin{array}{l}\text { alle } \\
(794 \text { svar })\end{array}$ \\
\hline $\begin{array}{l}\text { dokumentere } \\
\text { norskkunnskaper }\end{array}$ & 112 & 120 & 147 & $\begin{array}{l}379 \\
(48 \%)\end{array}$ \\
\hline søke arbeid & 59 & 78 & 52 & $\begin{array}{l}189 \\
(24 \%)\end{array}$ \\
\hline $\begin{array}{l}\text { søke opptak } \\
\text { på skole }\end{array}$ & 56 & 69 & 40 & $\begin{array}{l}165 \\
(21 \%)\end{array}$ \\
\hline annet & 19 & 15 & 27 & $\begin{array}{l}61 \\
(8 \%)\end{array}$ \\
\hline
\end{tabular}

Tabell 16: Informantenes motivasjon / kursmål

Som Tabell $17^{41}$ viser, har en tredjedel av informantene (34\%) ikke angitt hva deres sysselsetting i Norge er. Nesten halvparten av dem (47 \%) arbeider, noen av dem søker arbeider (12\%), eller studerer (7\%).

\begin{tabular}{|l|l|l|l|l|}
\hline S1 & polsk & engelsk & tysk & $\begin{array}{l}\text { alle } \\
(794 \text { svar })\end{array}$ \\
\hline \multirow{2}{*}{ studerer } & 10 & 8 & 26 & 44 \\
& $(5 \%)$ & $(4 \%)$ & $(13 \%)$ & $(7 \%)$ \\
\hline \multirow{2}{*}{ arbeider } & 112 & 80 & 90 & 282 \\
& $(56 \%)$ & $(40 \%)$ & $(45 \%)$ & $(47 \%)$ \\
\hline \multirow{2}{*}{ søker arbeid } & 19 & 33 & 21 & 73 \\
& $(9,5 \%)$ & $(16,5 \%)$ & $(10,5 \%)$ & $(12 \%)$ \\
\hline \multirow{2}{*}{ annet } & 59 & 79 & 63 & 201 \\
& $(29,5 \%)$ & $(39,5 \%)$ & $(31,5 \%)$ & $(34 \%)$ \\
\hline
\end{tabular}

Tabell 17: Informantenes sysselsetting $i$ Norge

${ }^{40}$ Det var mulig å gi flere svar på dette spørsmålet i spørreundersøkelsen.

${ }^{41}$ Det var mulig å gi flere svar på dette spørsmålet i spørreundersøkelsen. 
Også når det gjelder opplysninger angående yrke, vil størsteparten (42\%) ikke angi noen informasjoner, som det står i Tabell 18. Blant de som har oppgitt sitt yrke, er de fleste ansatt i servicenæring (16\% av alle informantene) og i helsevesenet (12\%). De som jobber i helsevesenet er først og fremst sykeog hjelpepleiere, leger, og de som gjennomfører annet helsearbeid. Yrkesspektret er generelt sett bredt - informantene er både høykvalifiserte spesialister (f.eks. forskere) og ansatte $\mathrm{i}$ enklere stillinger (f.eks. i manuelt arbeid).

\begin{tabular}{|c|c|c|c|c|}
\hline S1 & polsk & engelsk & tysk & alle \\
\hline servicenæring & $\begin{array}{l}31 \\
(15,5 \%)\end{array}$ & $\begin{array}{l}24 \\
(12 \%)\end{array}$ & \begin{tabular}{|l|}
43 \\
$(21,5 \%)$
\end{tabular} & \begin{tabular}{|l|}
98 \\
$(16 \%)$
\end{tabular} \\
\hline helsearbeid & $\begin{array}{l}39 \\
(19,5 \%)\end{array}$ & \begin{tabular}{|l|}
5 \\
$(2,5 \%)$
\end{tabular} & $\begin{array}{l}28 \\
(14 \%)\end{array}$ & $\begin{array}{l}72 \\
(12 \%) \\
\end{array}$ \\
\hline kontorarbeid & \begin{tabular}{|l|}
10 \\
$(5 \%)$ \\
\end{tabular} & \begin{tabular}{|l|}
28 \\
$(14 \%)$ \\
\end{tabular} & \begin{tabular}{|l|}
7 \\
$(3,5 \%)$ \\
\end{tabular} & \begin{tabular}{|l|}
45 \\
$(8 \%)$ \\
\end{tabular} \\
\hline manuelt arbeid & $\begin{array}{l}11 \\
(5,5 \%)\end{array}$ & $\begin{array}{l}11 \\
(5,5 \%)\end{array}$ & $\begin{array}{l}17 \\
(8,5 \%)\end{array}$ & $\begin{array}{l}39 \\
(7 \%)\end{array}$ \\
\hline $\begin{array}{l}\text { akademisk yrke } \\
\text { og forskning }\end{array}$ & $\begin{array}{l}7 \\
(3,5 \%)\end{array}$ & \begin{tabular}{|l|}
19 \\
$(9,5 \%)$
\end{tabular} & \begin{tabular}{|l|}
11 \\
$(5,5 \%)$ \\
\end{tabular} & $\begin{array}{l}37 \\
(6 \%) \\
\end{array}$ \\
\hline opplæring/undervisning & $\begin{array}{l}10 \\
(5 \%)\end{array}$ & \begin{tabular}{|l|}
16 \\
$(8 \%)$ \\
\end{tabular} & \begin{tabular}{|l|}
7 \\
$(3,5 \%)$ \\
\end{tabular} & \begin{tabular}{|l|}
33 \\
$(6 \%)$ \\
\end{tabular} \\
\hline kultur & $\begin{array}{l}3 \\
(1,5 \%)\end{array}$ & $\begin{array}{l}4 \\
(2 \%) \\
\end{array}$ & \begin{tabular}{|l|}
1 \\
$(0,5 \%)$ \\
\end{tabular} & \begin{tabular}{|l|}
8 \\
$(1 \%)$ \\
\end{tabular} \\
\hline privat næringsliv & 0 & $\begin{array}{l}4 \\
(2 \%)\end{array}$ & \begin{tabular}{|l|}
1 \\
$(0,5 \%)$
\end{tabular} & $\begin{array}{l}5 \\
(1 \%)\end{array}$ \\
\hline politi, toll, brann & 0 & \begin{tabular}{|l|}
1 \\
$(0,5 \%)$ \\
\end{tabular} & 0 & $\begin{array}{l}1 \\
(0 \%) \\
\end{array}$ \\
\hline transport & 0 & 0 & \begin{tabular}{|l|}
1 \\
$(0,5 \%)$
\end{tabular} & $\begin{array}{l}1 \\
(0 \%)\end{array}$ \\
\hline hjemmeværende & $2(1 \%)$ & \begin{tabular}{|l|}
3 \\
$(1,5 \%)$
\end{tabular} & $\begin{array}{l}4 \\
(2 \%) \\
\end{array}$ & \begin{tabular}{|l|}
9 \\
$(2 \%)$ \\
\end{tabular} \\
\hline annet & \begin{tabular}{|l|}
87 \\
$(43,5 \%)$ \\
\end{tabular} & \begin{tabular}{|l|}
85 \\
$(42,5 \%)$ \\
\end{tabular} & \begin{tabular}{|l|}
80 \\
$(40 \%)$ \\
\end{tabular} & \begin{tabular}{|l|}
252 \\
$(42 \%)$ \\
\end{tabular} \\
\hline
\end{tabular}

Tabell 18: Informantenes yrke 
De polsk-, engelsk- og tyskspråklige informantene hvis tekster er i ASK-korpuset, er voksne norskinnlærere. En typisk informant er ei 31 år gammel kvinne som har fått høyere utdanning og som har bodd i Norge i cirka ett år før hun har hatt prøven. Hun har tatt omtrent 300 kurstimer i norsk, og er mellom B1 og B2 nivå. Hun bruker norsk daglig, og arbeider. Testen har hun tatt for å dokumentere sine norskkunnskaper. Høyest sannsynlig jobber hun i servicenæring. Yrke er imidlertid den faktoren som varierer mest i dette utvalget norskinnlærere.

\subsubsection{Søket}

Fordi jeg i undersøkelsen trenger både korrekt bøyde adjektiver, og feilbøyde adjektiver, har jeg i søkemotoren $\mathrm{i}$ ASK-korpuset skrevet følgende fraser:

$$
\begin{aligned}
& {[\text { pos }=\text { "adj"] } \backslash<>\|<\text { del }>:: \text { language }=\text { "polsk" }} \\
& {[\text { pos }=\text { "adj" }] \backslash<>\|<\text { del }>:: \text { language }=\text { "engelsk" }} \\
& {[\text { pos }=\text { "adj"] }] \backslash<>\| \text { del }>: \text { language }=\text { "tysk" }}
\end{aligned}
$$

Frasene har plukket ut alle forekomster av adjektiver i den henholdsvis polske, engelske og tyske S1-gruppen. I tilfeller når adjektiver er bøyd ukorrekt, har jeg fått også en korrigert versjon av adjektivet (fra korrektkorpuset).

Ordklassetagger i ASK (annotert ved hjelp av OsloBergen-taggeren) bygger på ordklassefordelingen fra NRG (1997) der omfanget av adjektivklassen skiller seg fra det jeg bruker i dette arbeidet. Av den grunn har jeg fått i søket flere ord enn jeg har hatt behov for i undersøkelsen. Dessuten har det forekommet noen ganger feil i ordklassetaggingen der tvetydige ord (f.eks. $f a$ ) har blitt tagget som adjektiver selv om de har blitt brukt $i$ en annen betydning (i tilfellet $f \stackrel{\circ}{ }$ - som verb). Av den grunn var en bearbeidelse av dataene nødvendig. Den har jeg beskrevet i den neste seksjonen. 


\subsubsection{Bearbeidelsen av data}

Som resultat av søket har jeg fått til sammen 25.898 adjektiver. Tabell 19 viser antall adjektiver i hver av de tre S1gruppene som er svaret på søket jeg har gjennomført i søkemotoren i ASK-korpuset, og inkluderer ord som er feiltagget og som ikke er adjektiver ifølge definisjonen brukt i denne avhandlingen.

\begin{tabular}{|l|l|l|l|l|}
\hline S1 & polsk & engelsk & tysk & alle \\
\hline antall adj. & 8779 & 8389 & 8730 & 25.898 \\
\hline
\end{tabular}

Tabell 19: Antall adjektiver som resultat av søket $i$ ASK-korpuset

Etter å ha ekskludert feiltaggede ord samt ord som ikke samsvarer med definisjonen av adjektiver som anvendes her, har jeg fått cirka 1.000 adjektiver mindre i hver av S1-gruppene. Tabell 20 viser antall adjektiver etter korreksjonen. Tabellen presenterer dessuten totalantallet ord brukt i alle S1-gruppene og prosentandelen adjektivene utgjør i forhold til alle ordene. En gjennomsnittlig tekst består av 388 ord, og inneholder cirka $10 \%$ adjektiver. Tekster i Språkprøven er kortere enn tekster i Bergenstesten, og består i gjennomsnittet av respektivt 282 og 494 ord. Andelen adjektiver i Bergenstesten er litt større enn i Språkprøven, og utgjør 10,1 \% i forhold til 9,5\%.

\begin{tabular}{|l|l|l|l|l|}
\hline S1 & polsk & engelsk & tysk & alle \\
\hline antall adj. & 7813 & 7478 & 7677 & 22.968 \\
\hline totalantall ord & 77.801 & 76.149 & 78.833 & 232.783 \\
\hline$\%$ adj. i teksten & $10 \%$ & $9,8 \%$ & $9,7 \%$ & $9,9 \%$ \\
\hline
\end{tabular}

Tabell 20: Antall adjektiver etter korreksjonen, totalantall ord og relativt antall adjektiver ift. alle ordene i tekstene

Som Tabell 20 viser, bruker de polskspråklige norskinnlærerne både flest ord og flest adjektiver i sine tekster i forhold til de to øvrige morsmålsgruppene. De engelskspråklige bruker 
færrest ord og færrest adjektiver totalt sett, mens de tyskspråklige bruker relativt færrest adjektiver (i forhold til alle ordene i teksten).

Fordi mange adjektiver ikke kan bøyes, er det ikke mulig å bruke dem $i$ analysen av informantenes bøyningskunnskaper. Det er fire grupper ubøyelige adjektiver jeg har her sett bort fra. Til sammen utgjør de litt mindre enn $30 \%$ av alle adjektiver produsert av informantene i deres tekster. Den første gruppen utgjør adjektiver som ikke făr noen endelse i kongruensbøyning (m.a.o. er ubøyelige som f.eks. bra og annerledes). Den andre gruppen utgjør adjektiver som riktignok kan få en endelse i kongruensbøyning, men som i teksten opptrer i komparativ grad (bl.a. bedre, mindre). Fordi adjektiver i komparativ ikke kan samsvarsbøyes, er det meningsløst å ta disse adjektivene med i analysen. Den tredje gruppen adjektiver ekskludert fra denne analysen er adjektiver brukt adverbialt, og den siste gruppen (som er svært liten, og består av kun 11 ord) utgjør adjektiver brukt substantivisk ettersom heller ikke de kan bøyes i kongruens. Tabell 21 viser antall adjektiver i hver av S1gruppene fordelt etter typer bøyning. Bare tallene fra den tredje raden (som er markert med farge) er brukt $i$ analysen. De resterende radene presenterer antallet adjektiver som ikke kan bli analysert på grunn av manglende bøyning. I hver av S1gruppene er det dessuten to kolonner hvorav den ene viser totalantallet adjektiver, og den andre prosenten den gitte bøyningstypen utgjør i forhold til alle adjektivene brukt av den gitte S1-gruppen. 


\begin{tabular}{|c|c|c|c|c|c|c|c|c|}
\hline \multirow[b]{2}{*}{ S1 } & \multicolumn{2}{|c|}{ polsk } & \multicolumn{2}{|c|}{ engelsk } & \multicolumn{2}{|c|}{ tysk } & \multicolumn{2}{|c|}{ alle } \\
\hline & 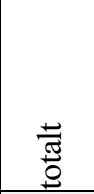 & 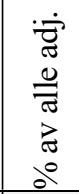 & 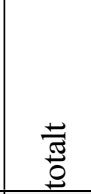 & 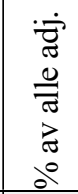 & 冞 & 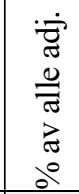 & 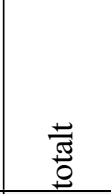 & 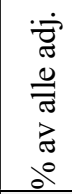 \\
\hline $\begin{array}{l}\text { adj. bøyd } \\
\text { i kongruens }\end{array}$ & 450 & 57 & 4.276 & 57,2 & 4.373 & 57 & 3.099 & 57 \\
\hline $\begin{array}{l}\text { adj. b } \\
\text { adver }\end{array}$ & 1.175 & 15 & 1.026 & 13,7 & 1.308 & 17 & 3.509 & 15,3 \\
\hline $\begin{array}{l}\text { adj. i } \\
\text { komparativ }\end{array}$ & 944 & 12,1 & 1.015 & 13,6 & 964 & 12,6 & 2.923 & 12,7 \\
\hline $\begin{array}{l}\text { ubøyelige } \\
\text { adj. }\end{array}$ & 1.244 & 15,9 & 1.155 & 15,4 & 1.027 & 13,4 & 3.326 & 14,9 \\
\hline $\begin{array}{l}\text { adj. brukt } \\
\text { substantivisk }\end{array}$ & 0 & 0 & 6 & 0,1 & 5 & 0,1 & 11 & 0 \\
\hline SUM & 7813 & 100 & 7478 & 100 & 7677 & 100 & 22868 & 100 \\
\hline
\end{tabular}

Tabell 21: Antall adjektiver etter bøyningstyper

Ifølge Tabell 21 har den S1-polske gruppen totalt produsert flest adjektiver som er brukt $i$ analysen. Relativt sett er det imidlertid den S1-engelske gruppen som har produsert flest adjektiver som er brukt $\mathrm{i}$ analysen. Likevel finnes det ingen signifikante forskjeller mellom de tre morsmålsgruppene når det gjelder antall forekomster av adjektivisk samsvarsbøyning produsert av informantene $\left(X^{2}=1,6013, d f=2, p>0,05\right)^{42}$.

I analysen har jeg sett bort fra stavefeil gjort i adjektivene så lenge de ikke gjelder selve bøyningsendelsen (f.eks. spessiel, $s ø k[=s y k]$, nytti). I tvetydige situasjoner der jeg ikke var i stand til å skille mellom stavefeil og feil bruk av endelse, var feilen kategorisert som feil bruk av endelse. Fordi korpuset ikke inneholder noen informasjoner om informantenes tankegang, var det ikke mulig å avgrense en type feil fra den andre (dvs. stavefeil fra feil i kongruens), og et valg måtte tas. Men så lenge det var klart at det dreide seg om et bøyelig adjektiv og man kunne skille ut en endelse, var ordet tatt inn i analysen.

${ }^{42}$ Kruskal-Wallis-testen. 
Korpuset inneholder også ord som er brukt adjektivisk, men som ikke finnes i norsk (f.eks. bondemessig, underholdsom, underjordlig). Dessuten er noen av adjektivene brukt i feil semantisk kontekst eller i feil betydning. Disse typene ukorrekthet hadde ingen påvirkning på analysen, i likhet med stavefeil. I alle disse tilfellene har jeg kun sett på bruken av endelsene. En feil er altså forstått som bruk av en ukorrekt endelse $(\varnothing,-e,-t)$ i forhold til språknormen. I denne oppgaven er feilene indikatorer på hvorvidt samsvarsbøyning er tilegnet eller ikke, og de er lagt størst fokus på. I den kvalitative analysen er også korrekt bruk av samsvarsbøyning sett på. Det må imidlertid understrekes at antall feil i adjektivisk samsvarsbøyning pluss antall korrekt samsvarsbøyde adjektiver utgjør $100 \%$ av alle adjektivene som er tatt med i analysen. Feilene og korrekt brukt kan følgelig forstås som to motsatte sider av det samme fenomenet. Derfor vil det å undersøke feilene si noe om kongruenstilegnelse like godt som det å undersøke korrekt bruk av kongruens. Fordi feilene er færre, kan de analyseres lettere.

\subsection{Kvantitative/statistiske metoder}

Som sagt ovenfor har korpuser den fordelen at de frembringer veldig mye data som kan si noe mer om en større del av populasjonen, og dermed brukes til generaliseringer. Med statistiske metoder kan store mengder data bearbeides, men siden det i grunnen dreier seg om matematiske beregninger, må slike metoder brukes med størst matematisk forsiktighet. Det er blitt utviklet ulike statistiske tester hvis mål Oakes kommenterer slik:

The purpose of statistical tests is thus to give us confidence in claims about the data, so that we may claim statistical significance for our results, by estimating the probability that the claims are wrong. (Oakes 1998: 9) 
Disse testene kan brukes til bestemte typer data som oppfyller bestemte krav, og det har også oppstått robuste verktøy i form av statistiske dataprogrammer (bl.a. R-programmet) som tar på seg selve gjennomføringen av disse testene, det vil si de matematiske beregningene. Valget av den riktige testen og selve forberedelsen av dataene slik at et statistisk program kan 'forstå' dem, er imidlertid forskernes ansvar. I min studie har jeg valgt R-programmet som beregningsprogramvare, der jeg har først importert mine data, og så gjennomført statistiske tester: Kruskal-Wallis, Mann-Whitney- og Wilcoxon-testen etter å ha først testet dataene i forhold til normaldistribusjon ved hjelp av Shapiro-Wilk-testen. Både R-programmet og testene er omhandlet i seksjonene nedenfor. De er beskrevet bare i den grad de blir anvendt i min undersøkelse, og ikke i sin helhet.

Bortsett fra å presentere resultatene fra de statistiske testene som vil si hvorvidt ulike grupper informanter er forskjellige eller ikke, vil jeg fremstille dataene mine ved hjelp av tabeller, diagrammer og figurer der både median og gjennomsnitt blir presentert. Å bare bruke gjennomsnitt er det mest typiske, men det kan ofte være problematisk ettersom hvis data ikke er normalt distribuert (og det er det som er tilfellet i denne studien), kan gjennomsnittet bli påvirket av ekstreme verdier, og med det samme forvrengt. Av den grunn er median oftere brukt som den typiske tendensen enn gjennomsnitt (Oakes 1998: 2). For å illustrere samspillet mellom median og gjennomsnitt bedre, angir jeg også den minste og største verdien.

\subsubsection{R-programmet}

$R$ er utviklet som et fritt statistisk programvareprosjekt som er tilgjengelig på Internett gjennom General Public Licence (GPL). Programmet er egentlig et komplett programmeringsspråk, og utgjør et miljø der man kan gjennomføre statistiske beregninger så godt som lage grafikk (Dalgaard 2008: vii). Selv om grensesnittet i R ikke er altfor enkelt, og å lære å bruke 
programmet tar tid og krever ganske mye innsats fra brukeren (særlig når hun ikke har kjennskap til programmering), har programmet mange fordeler. På R-prosjektets nettside nevnes det følgende:

$\mathrm{R}$ is an integrated suite of software facilities for data manipulation, calculation and graphical display. It includes

- an effective data handling and storage facility,

- a suite of operators for calculations on arrays, in particular matrices,

- a large, coherent, integrated collection of intermediate tools for data analysis,

- graphical facilities for data analysis and display either onscreen or on hardcopy, and

- a well-developed, simple and effective programming language which includes conditionals, loops, userdefined recursive functions and input and output facilities.

(hentet fra R-prosjektets nettside)

Ved hjelp av R-programmet har jeg utført alle de statistiske beregningene (dvs. de statistiske testene som er omtalt nedenfor), og laget noen av diagrammene som illustrerer dem.

\subsubsection{Shapiro-Wilk-testen}

$\AA$ velge en statistisk test beror på hva slags data man skal analysere. Man må blant annet se på hvor mange utvalg dataene kommer fra: ett, to eller flere, hvor mange målinger fra hver av gruppene man har, og sist men ikke minst hvilken type data man har til disposisjon. Her kommer det først og fremst an på om dataene er normalt distribuert eller ikke. Normaldistribusjon er definert av Salkind (2008: 135) som en distribusjon som tilfredsstiller tre krav: er symmetrisk, har asymptotisk hale, og der gjennomsnittet, medianen og typetallet faller på det samme punktet. Avhengig av tilstedeværelse av normaldistribusjon, velges det følgelig enten en parametrisk test (når dataene er normalt distribuert) eller en ikke-parametrisk test (i motsatt 
tilfelle), som blant annet Oakes (1998: 11) minner på. Det finnes flere metoder å teste normaldistribusjon på, en av dem er Shapiro-Wilk-testen. Denne testen kan med $95 \%$ sannsynlighet $(p=0,05)^{43}$ vise om dataene man har til rådighet, er normalt distribuert eller ikke (Field 2009: 144). Fordi dataene mine er i det meste ikke normalt distribuert (det er bare et tilfelle der de er normalt distribuert - i den tyskspråklige S1-gruppen i antall forekomster av adjektivkonkurens), og ellers er distribusjonen ikke normal, er jeg nødt til å bruke ikke-parametriske tester i min statistiske analyse: Kruskal-Wallis-testen, Mann-Whitneytesten og Wilcoxon-testen. Testene er omtalt nedenfor.

\subsubsection{Kruskal-Wallis-testen}

The Kruskal-Wallis analysis of ranks er ofte omtalt som en ikke-parametrisk ekvivalent til analysis of variance (ANOVA) som er brukt for flere sammenligningsgrupper (Cantos Gómez 2013: 45). Ved bruk av denne testen er det mulig å sammenligne resultatene til alle de tre morsmålsgruppene jeg analyserer (dvs. den polsk-, engelsk- og tyskspråklige) samtidig, og vise med 95 $\%$ sannsynlighet $(p=0,05)$ om forskjellene i performansen blant de tre gruppene er et konstant og permanent trekk ved disse gruppene, eller om de har oppstått tilfeldig, og gruppene i virkeligheten ikke skiller seg fra hverandre når det gjelder dette trekket. Når det forekommer et statistisk signifikant forskjell $(p<0,05)$, gir denne testen imidlertid ingen informasjon om hvor (dvs. mellom hvilke av gruppene) denne forskjellen befinner seg. Derfor er det behov for en post-hoc test, i dette tilfellet er det Mann-Whitney-testen. Det Kruskal-Wallis-testen

${ }^{43} \mathrm{P}=0,05$ er signifikansnivået jeg har valgt $\mathrm{i}$ denne oppgaven. Det er dessuten vanlig å velge signifikansnivået på $\mathrm{p}=0,01$ eller $\mathrm{p}=0,001$ (Rowntree 1981: 97).

I analysen tar jeg altså resultatet som statistisk signifikant når p-verdien er mindre enn 0,05. Da er det også markert med en asterisk (*). Høyere signifikans (når p-verdien er mindre enn 0,01 ) er markert med to asterisker $(* *)$, og en veldig høy statistisk signifikant forskjell (når p-verdien er mindre enn 0,001 ) er markert med tre asterisker $(* * *)$. 
gjør, er kun å sjekke om det i det hele tatt finnes en forskjell blant gruppene eller ikke. Denne testen har jeg anvendt til å få evidens for intragruppe-homogenitet og intergruppe-heterogenitet $\mathrm{i}$ transferanalysen, og flere steder $\mathrm{i}$ analysen av andre faktorer som kan påvirke andrespråkstilegnelsen.

Både $\mathrm{i}$ denne testen og $\mathrm{i}$ alle de andre testene baserer de statistiske beregningene seg på relativt antall feil, dvs. antall feil en informant gjorde $\mathrm{i}$ forhold til antall kongruensforekomster hun produserte - på denne måten tallene kan sammenlignes. Dette innebærer at for hver informant er det summert både antallet adjektiver, og antallet feil hun gjorde, og på dette grunnlaget beregnet det relativet antallet feil.

\subsubsection{Mann-Whitney-testen}

Testen jeg har valgt som en post-hoc test til KruskalWallis-testen er the Mann-Whitney U-test, som igjen kan betraktes som en ikke-parametrisk ekvivalent til t-testen (Cantos Gómez 2013: 45). Denne testen blir blant annet anvendt når man får et statistisk signifikant resultat $(p<0,05)$ fra Kruskal-Wallis-testen, og ellers når man sammenligner to grupper $\mathrm{i}$ forhold til en faktor som muligens kan være ulikt fordelt mellom de to gruppene. Ved bruk av denne testen har jeg i transferanalysen sammenlignet hvert par av morsmålsgruppene separat (dvs. det polsk-engelske, polsk-tyske og engelsk-tyske) for forekomsten av det samme trekket som jeg tidligere har undersøkt ved hjelp av Kruskal-Wallis-testen. Mann-Whitney-testen kan med $95 \%$ sannsynlighet $(p=0,05)$ bekrefte eller avkrefte at det gitte trekket er et fast felles eller differensierende trekk for det undersøkte paret. Fordi jeg har gjennomført denne testen tre ganger for hvert trekk ${ }^{44}$ (ettersom hvert par var testet separat), var en korrigering for multippel

${ }^{44}$ I transferanalysen var det tre sammenligningsgrupper, derfor måtte testen kjøres tre ganger. I andre tilfeller testen var brukt (f.eks. i å sjekke hvorvidt generelle norskkunnskaper målt i CEFR-nivåer har påvirkning på antall feil i adjektivisk samsvarsbøyning i norsk, var testen brukt 5 ganger - én gang for hvert sammenligningspar. 
testing nødvendig. Jeg har valgt Bonferroni-korrigering, som er omtalt nedenfor. Som utfylling av Kruskal-Wallis-testen er Mann-Whitney-testen brukt til å først og fremst få evidens for intragruppe-homogenitet og intergruppe-heterogenitet i transferanalysen, ved siden av til å teste påvirkningen av andre såkalte sosiale faktorer, blant annet innflytelse av generelle norskkunnskaper på performansen i norsk adjektivisk samsvarsbøyning i den S1-polsksprålige gruppen.

\subsubsection{Wilcoxon-testen}

The Wilcoxon signed-ranks test brukes til sammenligninger innen én gruppe, og kan betraktes som et ikke-parametrisk alternativ til paret t-test (Cantos Gómez 2013: 45). I min undersøkelse er den brukt til å få evidens for innenspråklige ulikheter, det vil si for å sammenligne hvordan hver av S1gruppene klarte seg $\mathrm{i}$ adjektivkongruensen $\mathrm{i}$ attributiv og predikativ stilling. Det samme utvalget (S1-gruppen) har altså frembrakt to datasett. Ved hjelp av Wilcoxon-testen kan det bekreftes eller avkreftes med $95 \%$ sannsynlighet $(p=0,05)$ at en gitt S1-gruppe oppfører seg annerledes i to ulike situasjoner (i dette tilfellet at den gjør flere feil i én av stillingene). $\AA$ få et statistisk signifikant resultat $(p<0,05)$ her betyr at det er den gitte S1-gruppens konstant trekk at den (ikke) gjør flere feil i enten attributiv eller predikativ stilling $i$ norsk, og at den forskjellen i antall feil mellom de to syntaktiske posisjonene som tross alt finnes, ikke er tilfeldig. Fordi denne testen må gjentas tre ganger (den må gjennomføres for hver S1-gruppe separat), behøves det å anvende en korrigering for gjentatte sammenligninger - Bonferroni-korrigering ${ }^{45}$, omtalt nedenfor.

${ }^{45}$ Når testen er brukt bare i undersøkelsen av den polskspråklige gruppen, er ingen korrigering brukt. 


\subsubsection{Bonferroni-korrigering}

Problemet med å teste de samme gruppene flere ganger er at det med hver test øker sannsynligheten for å få et statistisk signifikant resultat tilfeldig (Salkind 2008: 214). En slik situasjon er det man kaller type-I-feil i statistikken, det vil si «to accept a difference as significant when it is not» (Rowntree 2000: 119). For å eliminere risikoen for å få et tilsynelatende statistisk signifikant resultat mens det $\mathrm{i}$ virkeligheten ikke er signifikant, må man bruke korrigering for gjentatte sammenligninger. En av de mest brukte og rigorøse korrigeringene er Bonferroni-korrigering (Baayen 2009: 106). Den justerer p-verdien til antallet sammenligninger ved å dele signifikansnivået (i min analyse: 0,05 ) på antallet sammenligninger (her i de fleste tilfellene: 3). På denne måten får man et justert signifikansnivå på 0,017 (i tilfellet flere sammenligninger blir signifikansnivået enda lavere). For å påstå å ha oppnådd $95 \%$ sannsynlighet (en statistisk signifikant resultat med p-verdi $<0,05)$, må man egentlig oppnå det justerte signifikansnivået (f.eks. 0,017 - ved 3 sammenligniner).

\subsection{Metoden i transferanalysen}

En av de viktigste delene av denne oppgaven er å finne ut om tilegnelsen av adjektivkongruensen i norsk som S2 har noe med innlærernes morsmål å gjøre. Metodologien brukt i transferanalysen er hentet fra Jarvis og Pavlenko (2008), og Jarvis (2010). Selve metodologien ble framstilt for første gang i Jarvis' artikkel fra 2000. Metoden bygger på fire typer observasjoner for tverrspråklig innflytelse (intragruppehomogenitet, intergruppe-heterogenitet, tverrspråklig performansesamsvar og innenspråklige ulikheter). Den fjerde typen (innenspråklige ulikheter) ble lagt til i den nyeste artikkelen fra Jarvis (2010), mens alle de tre resterende typene ble omtalt allerede i Jarvis (2000). Vanligvis må man finne bevis på alle de fire kravene for å kunne klassifisere et fenomen som transfer: 
Methodological rigor nevertheless requires one to test for all three ${ }^{46}$ potential effects, which not only allows for the verification of L1 influence, but also provides for a fuller characterization of the nature, strength, pervasiveness, and independence or interdependence of L1 influence relative to other factors (e.g., age, L2 proficiency; ...). (Jarvis 2000: 255)

Det at man ikke er i stand til å få bevis på alle kravene, utelukker imidlertid ikke muligheten at det tross alt dreier seg om tverrspråklig innflytelse i det tilfellet, og at man kan påvise det. Noen ganger kan en type observasjoner supplere en annen dersom den første ikke er oppnåelig:

Fortunately, the fact that the four types of evidence are interrelated means not only that they support one another, but also that they can sometimes be used to substitute for one another when it is impossible to collect data relevant to all four types of evidence. (Jarvis 2010: 182)

Nedenfor presenterer jeg hvordan logikken bak hver av de fire kravene ser ut, og forklarer hvordan metoden blir anvendt $\mathrm{i}$ min undersøkelse.

\subsubsection{Intragruppe-homogenitet}

I Jarvis og Pavlenko (2008: 43) er det gitt følgende rasjonalet for intragruppe-homogenitet (eng. intragroup homogeneity):

${ }^{46}$ Da Jarvis skrev det i 2000, var det snakk om bare tre potensielle effekter, og den fjerde ble nevnt først i Jarvis (2010). 


\begin{tabular}{|ll|}
\hline Rationale for Intragroup Homogeneity as Evidence of CLI \\
\hline Whereas: & $\begin{array}{l}\text { language users performance in a source } \\
\text { language is determined inter alia by their } \\
\text { knowledge of that source language, }\end{array}$ \\
If: & $\begin{array}{l}\text { a group of language users shares a similar } \\
\text { knowledge of a source language, }\end{array}$ \\
Then: & their performance in the source language should \\
& be expected to be relatively uniform, and \\
& their knowledge of the source language is also \\
& assumed to affect their performance in a recipient \\
& language, \\
Then: & the group of language users in question should be \\
& expected to show a level of uniformity in their use \\
& of the recipient language that is comparable to the \\
level of uniformity they display in their use of the \\
source language.
\end{tabular}

Tabell 22: Rasjonalet for intragruppe-homogenitet

Logikken som står bak intragruppe-homogenitet fenomenet, er følgende: hvis en gruppe språkbrukere har den samme kunnskapen om et kildespråk, og hvis kunnskapen om kildespråket påvirker performansen i et målspråket, da vil gruppemedlemmene oppføre seg likt i målspråket (Jarvis \& Pavlenko 2008: 41).

Som Jarvis (2010s: 173) poengterer, trenger den første typen observasjoner en kvantitativ begrunnelse, men også en kvalitativ begrunnelse er mulig. I min undersøkelse vil jeg analysere intragruppe-homogenitet og intergruppeheterogenitet samtidig ettersom de statistiske testene ${ }^{47}$ jeg vil bruke her, tillater det. Testene jeg vil bruke i denne analysen, er: KruskalWallis-testen for sammenligning av alle S1-gruppene samtidig, og Mann-Whitney-testen som en post-hoc test når et statistisk signifikant resultat blir oppnådd i Kruskal-Wallis-testen. MannWhitney-testen vil bli gjennomført tre ganger - en gang for

${ }^{47}$ Mer om statistiske tester befinner seg i underkapittelet Kvantitative /statistiske metoder. 
hvert av morsmålsgruppeparene (den polsk-engelske, polsk-tyske og engelsk-tyske), og Bonferroni-korrigering vil bli anvendt her.

Når det gjelder mine korpusdata, er det der ingen informasjon om informantenes morsmålskunnskaper. Det er imidlertid rimelig å anta at fordi de er voksne morsmålsbrukere av polsk, engelsk og tysk, er de også flytende brukere av sine morsmål. Informantene kan selvfølgelig være brukere av forskjellige dialekter, registre og idiolekter i sine morsmål, men slike data er ikke tilgengelige i ASK-korpuset. Det er altså blitt gjort en forenkling for undersøkelsens mål. Et annet problem beror på om informantene har lik kunnskap om målspråket, det vil si norsk. På den ene side er det umulig å få vite hva nøyaktig innlærerne vet om norsk (siden det er deres psykolingvistiske kunnskaper det gjelder), men på den annen har alle av dem bestått enten Språkprøven eller Bergenstesten, noe som peker på at de vet omtrent like mye om norsk. Dessuten tar de to statistiske testene som er brukt i denne analysen (dvs. KruskalWallis-testen og Mann-Whitney-testen) hensyn til hvor (u-)likt en gitt gruppe er i forhold til det trekket som analyseres, det vil si antall feil i adjektivkongruens i norsk i dette tilfellet.

\subsubsection{Intergruppe-heterogenitet}

En annen type observasjoner som fungerer som evidens for tverrspråklig innflytelse er intergruppe-heterogenitet (eng. intergroup heterogeneity). Jarvis og Pavlenko (2008: 45) gir følgende rasjonalet for denne typen observasjoner: 
Rationale for Intergroup Heterogeneity as Evidence of CLI

If: two or more groups of language users speak different source languages, and

If: their knowledge of the source language is assumed to affect their performance in a common recipient language,

Then: the groups of language users in question should be expected to show clear differences in their use of the recipient language.

Tabell 23: Rasjonalet for intergruppe-heterogenitet

Logikken i intergruppe-heterogenitet bygger på at dersom to eller flere grupper innlærere har kunnskap om forskjellige kildespråk, og dersom kunnskapen om kildespråket påvirker kunnskapen om målspråket, da vil performansen i målspråket se ulikt ut (Jarvis \& Pavlenko 2008: 43). Her er det mulig med tre typer sammenligninger: Type A omfatter sammenligninger av performansen i det samme målspråket av brukere av forskjellige kildespråk; Type $\mathrm{B}$ omfatter sammenligninger av performansen av mono- og bilingvale brukere av det samme målspråket; og Type $\mathrm{C}$ omfatter sammenligninger av performansen av mono- og bilingvale brukere av det samme kildespråket (ibid.: 43-44). Den typen evidens er sagt å være avgjørende når det gjelder å skille mellom transfer og utviklingsmønstre som alle innlærere av et gitt målspråk følger når man gjør en sammenligning av typen A (Jarvis 2000: 257). Et forbehold som må tas ved denne typen observasjoner, er at kildespråkene man undersøker påvirkning på målspråket av, må være forskjellige fra hverandre, iallfall i forhold til det trekket man undersøker (når det gjelder polsk, engelsk og tysk, forekommer det vesentlige forskjeller i samsvarsbøyning av adjektiver, noe som er gjort greie for i kapittelet Adjektiver og kongruens, side 83-87).

I likhet med intragruppe-homogenitet fokuserer også denne typen observasjoner på kvantitativ analyse, og ved bruk av statistiske tester (f.eks. Kruskal-Wallis-testen og Mann-Whitney- 
testen) kan de to typene observasjoner undersøkes samtidig ettersom de ser om variasjonene mellom gruppene er større enn variasjonene innen gruppene (og hvis dette er tilfellet, blir kravene oppfylt).

I min studie vil jeg bruke sammenligninger av typen A ettersom jeg skal sammenligne de polskspråkliges performanse i norsk med performansen av de engelsk- og tyskspråklige. Finnes det statistisk signifikante forskjeller i bruk av adjektivisk samsvarsbøyning blant de tre morsmålsgruppene, er det formodentlig bevis på at det virkelig forekommer tverrspråklig innflytelse $\mathrm{i}$ dette tilfellet (selvfølgelig må alle de tre andre kravene for transfer også påvises). Finnes de ikke, da er det snarere generelle utviklingsmønstre som har størst betydning i tilegnelsen av den adjektiviske kongruensen i norsk.

\subsubsection{Tverrspråklig performansesamsvar}

Den tredje typen evidens har mer fokus på kvalitativ analyse siden den beror på å påvise at innlærernes performansemønstre i målspråket samsvarer med deres performansemønstre i kildespråket (Jarvis 2010: 173). Rasjonalet for tverrspråklig performansesamsvar (eng. crosslinguistic performance congruity) er fremstilt i Jarvis og Pavlenko (2008: 46) slik:

\section{Rationale for Crosslinguistic Performance Congruity as Evidence of CLI}

Whereas: language users' performance in a source language is determined by their knowledge of that language,

If: their performance in a recipient language is also assumed to be affected by their knowledge of the source language,

Then: the language users in question should be expected to show similarities between their performance in the source language and their performance in the recipient language. 
Logikken i tverrspråklig performansesamsvar bygger på at dersom innlærerens performanse i kildespråket påvirkes av hennes kunnskaper om det språket, og at dersom performansen i målspråket påvirkes av innlærernes kunnskaper om kildespråket, da er det å forvente at innlæreren vil vise lignende adferd i begge språkene. Analysen her er som sagt kvalitativ og beror på å vise at innlærerne oppfører seg likt i kilde- og målspråket. Dette kan for eksempel gå ut på at dersom det ikke finnes adjektivisk samsvarsbøyning $\mathrm{i}$ et kildespråk (som i engelsk), vil innlærere av et målspråk der det finnes adjektivisk samsvarsbøyning (f.eks. norsk) som snakker dette kildespråket, ikke samsvarsbøye adjektiver i dette målspråket. Analysen baserer seg altså på å sammenligne innlærernes performanse $\mathrm{i}$ kilde- og målspråket.

Et av de viktigste hindrene i denne typen observasjoner, særlig når dataene man har til rådighet, kommer fra et elektronisk innlærerkorpus, er at man ofte ikke (iallfall er det ikke tilfellet i ASK-korpuset) disponerer dataene produsert av hver innlærer både i morsmålet og i andrespråket. En vei å omgå dette problemet (og det vil jeg gjøre i min analyse) er å sammenligne innlærernes performanse i målspråket med deres forventede performanse i kildespråket, det vil si med normalbruk (dvs. bruken omtalt som vanlig i grammatikkbeskrivelser av de gitte språkene) av det gitte grammatiske trekket som blir analysert, i dette tilfellet adjektivisk samsvarsbøyning. I min studie har jeg selv oversatt ytringene innlærerne av polsk, engelsk og tysk har produsert, til respektivt polsk, engelsk og tysk, og konsultert morsmålsbrukere av disse språkene for å forsikre oversettelsenes korrekthet. Etterpå har jeg sett på om adjektivisk samsvarsbøyning var til stedet i kilde- og målspråket, og om den var korrekt anvendt.

\subsubsection{Innenspråklige ulikheter}

Innenspråklige ulikheter er den typen evidens som ble presentert senest, det vil si i Jarvis' artikkel fra 2010. Den har 
blitt til på grunn av en mangel som først ble synlig ved bruk av et heuristisk begrepsapparat til de allerede eksisterende navnene på fenomenene: intragruppe-homogenitet, intergruppe-heterogenitet og tverrspråklig performansesamsvar. Disse begrepene ble erstattet med respektivt: innen-gruppe likheter (eng. withingroup similarities), mellom-gruppe forskjeller (eng. betweengroup differences) og mellom-språklige likheter. Da ble det oppdaget at det mangler en annen mulighet, nemlig innenspråklige forskjeller eller intralingvale kontraster (eng. intralingual contrast). Denne typen evidens har noe til felles med hver av de tre resterende typene:

Its relationship with intragroup homogeneity can be seen in the fact that both types of evidence must necessarily involve the comparison of multiple entities; in the case of intralingual contrasts, the entities in question are features of the target language rather than speakers of a particular source language. Next, like cross-language congruity, intralingual contrasts need to be based on qualitative relationships between the source language and the target language. Finally, like intergroup heterogeneity, intralingual contrasts should emphasize differences - in this case, differences in learners' performance on features of the target language that vary with respect to how they correspond to features of the source language. (Jarvis 2010: 175)

For å finne bevis på denne typen observasjoner skal man altså dele opp målspråkets strukturer i mindre enheter slik at de ikke jevnt korresponderer med strukturenhetene i kildespråket, og analysere kvalitativt hvordan innlærerne med det kildespråket bruker disse strukturenhetene i målspråket. Hvis bruksmønstret i målspråket er likt det i kildespråket, kan det dreie som om tverrspråklig innflytelse i dette tilfellet (selvfølgelig når også de andre kravene for transfer er tilfredsstilt).

I min undersøkelse vil denne typen observasjoner gjelde først og fremst bruken av adjektivisk samsvarsbøyning i attributiv og predikativ stilling. Av alle de tre språkene som er morsmålene til mine informanter, er det kun tysk som skiller 
mellom tilstedeværelse og fravær av adjektivisk samsvarsbøyning $\mathrm{i}$ attributiv (tilstedeværelse) og predikativ (fravær) stilling. Hvis det altså viser seg at de tyskspråklige informantene samsvarsbøyer norske adjektiver i attributiv stilling, men unnlater å gjøre det i predikativ stilling, kan det være bevis på at det er tverrspråklig innflytelse som styrer deres oppførsel.

\subsection{Kvalitativ metode}

I min analyse av de polskspråklige norskinnlærernes performanse i samsvarsbøyning av norske adjektiver benytter jeg meg først og fremst av kvantitative metoder, og dataene $\mathrm{i}$ denne studien (hentet fra ASK-korpuset) er egentlig valgt med hensyn til denne typen metode. Likevel fordi arten av dataene gjør det også mulig å analysere dataene kvalitativt, vil jeg anvende også denne metoden i den grad det lar seg gjøre.

Kvalitativ forskning er ofte vanskelig å definere fordi det finnes mye ulikt bak dette begrepet, men Friedman (2012: 181-183) lister opp dens åtte karakteristikker:

- Open inquiry,

- Inductive,

- Naturalistic,

- Descriptive and interpretative,

- Multiple perspectives,

- Cyclical,

- Attention to context,

- Focus on the particular.

Av disse vil jeg rette meg til tre: induksjon, deskriptiv og interpretativ fremgangsmåte og åpent spørsmål (i mindre grad). Induktiv karakter av den kvalitative analysen beror på at jeg skal studere detaljer for så å skape et bredere bilde av fenomenene jeg studerer. Analysen består av en kombinasjon av beskrivelse og tolkning av fenomenene. Ifølge Friedman (ibid.) finnes det vanligvis ikke noen hypoteser satt på begynnelsen i en kvalitativ 
undersøkelse, men snarere prøver man å få svar på et åpent spørsmål. I den kvalitative analysen undersøker jeg og prøver å finne svar på følgende forskningsspørsmål:

1) Hvilke typer feil i samsvarsbøyning er gjort, det vil si hvilke endelser er blandet sammen? Hva kan være årsaken til feilene?

2) Hva er den grammatiske konteksten til feilene? Er det en tendens til at feilene oftere forekommer ved ubestemte / bestemte former, entall / flertall, i hankjønn / hunkjønn / intetkjønn? Hva er konteksten til korrekt bruk av den adjektiviske samsvarsbøyningen? Finnes det noen samsvarsbøyningskategorier som innlærerne performerer oftere ukorrekt enn korrekt i?

3) Hvilke egenskaper har de adjektivene som oftest er bøyd korrekt og ukorrekt? Hører de til det regelmessige paradigmet eller viser de noen avvik fra paradigmet?

Svaret på disse spørsmålene vil sammen med transferanalysen og analysen av de sosiale faktorene si noe om hvordan kongruenstilegnelse hos de polskspråklige norskinnlærerne ser ut, og hvilke faktorer som påvirker den.

\subsection{Metodologiske begrensinger}

En av de største utfordringene og samtidig begrensningene i denne oppgaven er mangelen på standardtalemål i Norge. Riktignok er datamaterialet jeg bruker, skriftlig, og det finnes to standardskriftspråk i Norge: bokmål og nynorsk (alle besvarelsene i ASK-korpuset er likevel skrevet i bokmål), men mangelen på standardtalemål kan ha påvirkning på den innputten innlærerne får når de lærer språket. I sin artikkel om dialektenes status i Norge og Polen refererer Garbacz (2014) til Jahr og Janicki (1995) som sier at «det ikke finnes noen talt varietet som representerer 'den norske nasjonen' mer enn andre varieteter, og som slik kan betraktes som et norsk standardtalemål» (Garbacz 2014: 32). Det er imidlertid en stadig diskusjon om det i Norge eksisterer et standardtalemål eller ikke (se f.eks. Jahr \& Mæhlum 2009). Garbacz (ibid.) 
påpeker at det i stedet er en bred bruk av dialekter i Norge, og at å snakke dialekt er godt akseptabelt i Norge, også i offentlige situasjoner. Det hevdes til å med (bl.a. Sandøy 1996) at å ha norsk som førstespråk betyr å ha en eller annen norsk dialekt som førstespråk. En slik situasjon kan sikkert påvirke norskinnlærere i Norge som i hver muntlig kommunikasjon møter ulike dialekter ettersom innputten (som er definert av Gass \& Selinker (1994: 304) som «the language to which learners were exposed») de får er så forskjellig som de norske dialektene er. Ulikheter i innlærernes performansen kan altså ha noe å gjøre med bostedet i Norge og med dialektene de hører til daglig. Allikevel inneholder ASK-korpuset ingen informasjon om hvor i Norge informantene bor og har bodd, og hvilke dialekter de er utsatt for. En sannsynlig påvirkning av dialektene er derfor umulig å sjekke med det datamaterialet jeg har til rådighet.

En annen viktig begrensning i denne studien avhenger av typen data jeg har valgt til analysen, nemlig korpusdata. Andrespråkslæring er en kognitiv prosess som skjer i sinnet på et menneske, og å undersøke den betyr på en måte å undersøke innlærerens kognisjon, noe som ikke er gjennomførbart i det hele tatt. Psykolingvistiske analysemetoder kan på en indirekte måte måle innlærerens kunnskaper. Slike metoder kan imidlertid ikke anvendes med den slags data jeg står til rådighet. Metoden jeg bruker i denne avhandlingen beror på å undersøke innlærernes språkbruk (performanse), som, fordi den er påvirket av deres kunnskaper (kompetanse), kan nettopp si noe om kompetansene, noe som blant Ortega (2013: 82) har poengtert. Det må likevel ikke glemmes at det innlærerne produserer, ikke nødvendigvis må gjenspeile det de kan nøyaktig ettersom det kan oppstå flere hindrer på veien fra sinnet til det reelle uttrykket av tanken på papiret (slik det var i tilfellet mine informanter som skrev stiler). Her kan man regne med flere mulige forklaringer: fra distraherende faktorer (f.eks. stress), gjennom ulike funksjonshemminger (bl.a. dysleksi), vanlige stavefeil, til dårlig humør og mye annet. Til tross for alle disse 
forstyrrelsene, er det fremdeles mulig å si noe om kompetansen basert på performansen.

En enda annen begrensning gjelder den pseudolongitudinelle metoden. Denne metoden gjør det mulig å si noe om språkutviklingen hos en S1-gruppe generelt, men fordi målingene ikke har blitt tatt fra en og samme informant flere ganger, er det egentlig umulig å si noe om den enkeltes språkutvikling. Det man kan gjøre, er bare å trekke noen generelle konklusjoner om hele innlærergruppen. 


\section{Analyse}

I dette kapittelet presenterer jeg analyser jeg har gjennomført på datamaterialet omtalt i Metode-kapittelet. I det første underkapittelet beskriver jeg de polskspråklige informantenes performanse i norsk kongruensbøyning av adjektiver, og tar for meg både feilene informantene produserte og korrekt bruk. Videre, i det andre underkapittelet undersøker jeg hvilke sosiale faktorer som påvirker de polskspråklige norskinnlærernes performanse i samsvarsbøyning av norske adjektiver. Det tredje underkapittelet inneholder transferanalysen der jeg sammenligner performansen til polsk-, engelsk- og tyskspråklige norskinnlærere i samsvarsbøyning av norske adjektiver. Ettersom transferanalysen omfatter både kvantitative og kvalitative metoder, er den behandlet separat. Dette kapittelet består altså av tre underkapitler, og er avsluttet med en oppsummering.

Et problem med å vurdere tilegnelsen av norsk adjektivbøyning er at det egentlig ikke kan skilles mellom mangel på kongruens og adjektivbøyning i maskulinum/femininum ettersom de morfologisk uttrykkes på samme måte (dvs. med ingen endelse). En måte dette problemet kan løses på, er å betrakte begge tilfellene som null-kontekst for adjektivisk samsvarsbøyning, noe som fører til at det bare kan være snakk om en kontekst for adjektivisk samsvarsbøyning i tilfellet $-t$ og $-e$ endelse. For å lykkes i adjektivisk samsvarsbøyning, må man for det første lykkes i å identifisere tilstedeværelsen av (eller mangelen på) en samsvarsbøyningskontekst, og for det andre velge en endelse til denne samsvarsbøyningskonteksten, det vil si identifisere (den grammatiske) typen av samsvarsbøyningskonteksten. I korrekt norskbruk fører det å identifisere mangelen på adjektivisk samsvarsbøyning til å bruke adjektivet i naken form, det vil si uten noen endelse. I analysen nedenfor ser jeg altså på om kongruenskontekst ble identifisert korrekt (her er det snakk om to typer feil: når man ikke identifiserte kongruenskonteksten da den var til stedet, og når man 
identifiserte kongruenskonteksten da den ikke var til stedet, dvs. identifiserte den feilaktig), og om det ble brukt en korrekt endelse $(-e$ eller $-t)$ når kongruenskontekst var til stedet, og var indentifisert. I analysen skal jeg referere til disse tre feiltypene som: 1) mangel på kongruens (dvs. bruk av ingen endelse når en endelse, enten - $t$ eller $-e$, er nødvendig), 2) feil bruk av kongruens (dvs. bruk av en endelse, enten $-t$ eller $-e$, når ingen endelse er nødvendig), 3) feil kongruensendelse (dvs. enten bruk av - $t$-endelsen når $-e$-endelsen er nødvendig eller omvendt). Alle slags feil (både feil i å identifisere tilstedeværelsen av kongruenskontekst, og dens type) er her referert til som feil i samsvarsbøyning / adjektivkongruens.

\subsection{Samsvarsbøyning av adjektiver i de polskspråkliges mellomspråk}

De polskspråklige norskinnlærerne brukte i ASK til sammen 7.813 adjektiver. Som forklart i Metode-kapittelet, var jeg nødt til å ekskludere en del av adjektivene fordi de enten var ubøyelige (slik som f.eks. bra, annerledes, eller brukt i komparativ, slik som f.eks. bedre, flere), eller anvendt som adverbialer, og ikke i samsvarsbøyning (slik som f.eks. egentlig, spesielt oftest var brukt). I analysen ser jeg altså bare på bøyelige adjektiver i positiv og superlativ som er brukt $\mathrm{i}$ kongruens med det ordet / den frasen de modifiserer, det vil si kontrolløren. Forekomster av slike adjektiver er referert til som forekomster av adjektivkongruens / forekomster av adjektivisk samsvarsbøyning / kongruensforekomster / alle adjektiver brukt $i$ kongruens / alle samsvarsbøyde adjektiver / alle kongruensbøyde adjektiver i denne studien. Totalt var det 4.450 forekomster av adjektivkongruens i performansen til de polskspråklige informantene. Tabell 25 viser fordelingen av typene adjektivbøyning som de polskspråklige informantene brukte $\mathrm{i}$ sine tekster. Kolonnen med tallene som er brukt i analysen (dvs. bøyelige adjektiver brukt i kongruens) er markert med farge. 


\begin{tabular}{|l|l|l|l|l|l|}
\hline $\begin{array}{l}\text { Type } \\
\text { bøyning }\end{array}$ & kongruens & adverbial & komparativ & ubøyelig & SUM \\
\hline $\begin{array}{l}\text { Antall } \\
\text { fore- } \\
\text { komster }\end{array}$ & 4450 & 1175 & 944 & 1244 & 7813 \\
\hline $\begin{array}{l}\% \text { av alle } \\
\text { adjektiver }\end{array}$ & 57 & 15 & 12,1 & 15,9 & 100 \\
\hline
\end{tabular}

Tabell 25: Typer adjektivbøyning hos de polskspråklige informantene

Informantene brukte adjektiver både attributivt og predikativt, men de brukte dem i attributiv posisjon signifikant oftere enn i predikativ $\left(V=14.658,5, p<0,001^{* * *}\right)^{48}$. Tabell 26 viser fordelingen av adjektivene brukt $\mathrm{i}$ begge funksjonene. Det er angitt både totalt antall forekomster, og prosent forekomster i den gitte funksjonen $\mathrm{i}$ forhold til alle samsvarsbøyde adjektiver.

\begin{tabular}{|l|l|l|l|}
\hline Type bøyning & $\begin{array}{l}\text { Attributiv } \\
\text { stilling }\end{array}$ & $\begin{array}{l}\text { Predikativ } \\
\text { stilling }\end{array}$ & SUM \\
\hline Antall forekomster & 2727 & 1723 & 4450 \\
\hline$\%$ av alle adj. i kongr. & 61,3 & 38,7 & 100 \\
\hline
\end{tabular}

Tabell 26: Adjektiver i attributiv og predikativ posisjon brukt av de polskspråklige informantene

De polske testtakerne gjorde totalt 331 feil i adjektivisk samsvarsbøyning, noe som utgjør 7,4 \% ukorrekthet i all bruken av adjektivkongruens (alle adjektiver brukt i kongruens) i norsk som S2. Forskjellen i antall feil i attributiv og predikativ stilling er ikke statistisk signifikant $(V=5.290,5, p>0,05)^{49}$. Tabell 27 viser antall feil i hver funksjon. Tallene er oppgitt både som reelle forekomster og som brøk av alle kongruensbøyde adjektiver brukt av informantene (dvs. antall feil delt på totalantallet forekomster av adjektivisk samsvarsbøyning).

\footnotetext{
${ }^{48}$ Beregnet ved hjelp av Wilcoxon-testen.

${ }^{49}$ Resultatet beregnet ved hjelp av Wilcoxon-testen.
} 


\begin{tabular}{|l|l|l|l|}
\hline Type bøyning & $\begin{array}{l}\text { Attributiv } \\
\text { stilling }\end{array}$ & $\begin{array}{l}\text { Predikativ } \\
\text { stilling }\end{array}$ & SUM \\
\hline Antall forekomster & 188 & 143 & 331 \\
\hline av alle adj. i kongr. & 4,2 & 3,2 & 7,4 \\
\hline
\end{tabular}

Tabell 27: Antall feil i attributiv og predikativ posisjon gjort av de polskspråklige informantene

De fleste feilene de polskspråklige informantene gjorde, beror på at informantene feilet $\mathrm{i}$ å identifisere kontekster for adjektivkongruens. 201 ganger $(60,7 \%$ av alle feil $i$ adjektivkongruens) identifiserte de ikke samsvarsbøyningskonteksten når den var til stedet (mangel på kongruens), 119 ganger $(36 \%)$ identifiserte de en kontekst for adjektivkongruens når det ikke var noen kontekst til stedet (feil bruk av kongruens), og bare 11 ganger (3.3\%) brukte de en feil bøyningsendelse etter å ha identifisert konteksten for adjektivkongruens korrekt (feil kongruensendelse). Tabell 28 presenterer disse forholdene. I seksjonene nedenfor skal jeg ta meg av hver av de tre hovedtypene feil separat.

\begin{tabular}{|l|l|l|l|}
\hline Type feil & $\begin{array}{l}\text { Mangel } \\
\text { på kongruens }\end{array}$ & $\begin{array}{l}\text { Feil bruk } \\
\text { av kongruens }\end{array}$ & $\begin{array}{l}\text { Feil } \\
\text { kongruensendelse }\end{array}$ \\
\hline $\begin{array}{l}\text { Antall } \\
\text { forekomster }\end{array}$ & 201 & 119 & 11 \\
\hline $\begin{array}{l}\text { \% av alle feil } \\
\text { i adj.kongr. }\end{array}$ & 60,7 & 36 & 3,3 \\
\hline
\end{tabular}

Tabell 28: Typer feil i kongruens gjort av de polskspråklige informantene

\subsubsection{Mangel på kongruens}

$\AA$ ikke identifisere kontekst for adjektivisk samsvarsbøyning i norsk som S2 når en slik kontekst er til stedet, er den vanligste typen feil gjort av de polskspråklige informantene. Denne feiltypen ble gjort både når konteksten krevde bruken av - $e$-endelsen og $-t$-endelsen, både $\mathrm{i}$ attributiv og i predikativ posisjon. Tabell 29 viser antall feil av typen 'mangel på 
kongruens' fordelt etter manglende endelse og adjektivets funksjon i setningen. De samme forholdene er også presentert i Diagram 13.

\begin{tabular}{|l|l|l|l|l|}
\hline Feiltype & & $\begin{array}{l}\text { Mangel på } \\
-e \text {-endelse }\end{array}$ & $\begin{array}{l}\text { Mangel på } \\
-t \text {-endelse }\end{array}$ & SUM \\
\hline \multirow{2}{*}{$\begin{array}{l}\text { Attributiv } \\
\text { stilling }\end{array}$} & $\begin{array}{l}\text { Antall } \\
\text { forekomster }\end{array}$ & 62 & 52 & 114 \\
\cline { 2 - 5 } & $\begin{array}{l}\text { \% av alle feil } \\
\text { i adj.kongr. }\end{array}$ & 18,7 & 15,7 & 34,4 \\
\hline \multirow{2}{*}{$\begin{array}{l}\text { Predikativ } \\
\text { stilling }\end{array}$} & $\begin{array}{l}\text { Antall } \\
\text { forekomster }\end{array}$ & 49 & 38 & 87 \\
\cline { 2 - 5 } & $\begin{array}{l}\text { \% av alle feil } \\
\text { i adj.kongr. }\end{array}$ & 14,8 & 11,5 & 26,3 \\
\hline TOTALT & & $\begin{array}{l}111 \\
(33,5 \%)\end{array}$ & $\begin{array}{l}90 \\
(27,2 \%)\end{array}$ & $\begin{array}{l}201 \\
(60,7 \%)\end{array}$ \\
\hline
\end{tabular}

Tabell 29: Mangel på kongruens hos de polskspråklige informantene

\section{Antall feil av typen 'mangel på kongruens' i forhold til andre typer feil i kongruens}

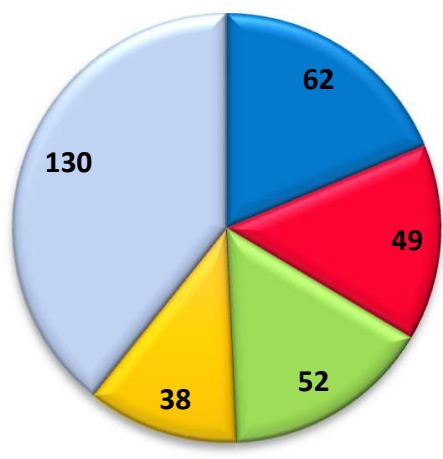

Q Mangel på e-endelse i attr. pos.

Mangel på e-endelse i pred. pos.

Mangel på t-endelse i attr. pos.

$\checkmark$ Mangel på t-endelse i pred. pos.

$\square$ Resten

Diagram 13: Ulike varianter av feil i 'mangel på kongruens'versus resterende typer feil i kongruens gjort av de polskspråklige informantene (antall feil oppgitt $i$ absolutte tall) 


\subsubsection{Mangel på -t-endelse}

$\AA$ overse konteksten for adjektivisk samsvarsbøyning i norsk som S2 ser ut å være sterkt forbundet med å feile i å identifisere substantivets genus. Av 90 feil totalt av denne typen er $76(84 \%)$ knyttet til at man tilskriver substantivet adjektivet står til, feil genus. I attributiv stilling finnes det 13 nominalfraser hvor informantene brukte et nøytrumssubstantiv med artikkelen en foran, og et adjektiv uten noen endelse. Slike feil er problematiske å vurdere med det datamaterialet jeg står til rådighet med (dvs. korpusdata) ettersom de ikke gir noen indikasjon på hva som var årsaken til at en slik feil oppsto. Er det slik at informantene kunne adjektivisk samsvarsbøyning, men de hadde problemer med å huske genus på substantivet (og slik sett samsvarsbøyde adjektivene korrekt antatt de var overbevisst om at de brukte riktig genus på substantivet), eller de kunne verken genusen eller den adjektiviske samsvarsbøyningen, og derfor gjorde feil i begge? Nedenfor presenterer jeg fem av slike feil:

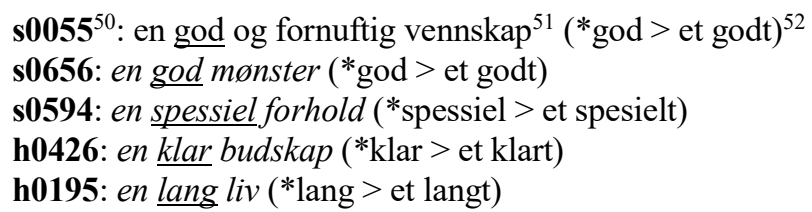

En vanligere feil $i$ attributiv stilling er imidlertid mangel på -t-endelse forbundet med mangelen på artikkelen foran substantivet. Det er 33 forekomster av slike feil hos de polskspråklige informantene. Også denne typen feil er

${ }^{50}$ Informantnummer.

${ }^{51}$ Informantenes ytringer er markert med kursiv og sitert $\mathrm{i}$ den formen det er tilstrekkelig til å se konteksten for samsvarsbøyning. De er dessuten gjengitt med original (dvs. informantenes) stavemåte, og derfor inneholder de noen ganger feil. Understrekingene er mine, og er brukt for å vise hvilke adjektiver analysen gjelder.

${ }^{52}$ Dette skal leses slik: brukt form «god» rettet til korrekt form «et godt». 
vanskelig å vurderes med det datamaterialet jeg har, og en psykolingvistisk undersøkelse kunne sikkert tilføye noen verdifulle forklaringer her. Det er altså ikke klart hva som informantene tror, er genusen på substantivet, og om de tilpasser den adjektiviske samsvarsbøyningen til den genusen de tenker på. Det kan også være en måte å unngå en vanskelig situasjon på - å utelate artikkelen man ikke husker. Det er følgelig heller ikke klart på hvilket grunnlag adjektivet (ikke) ble bøyd. Kanskje er konteksten for samsvarsbøyning mindre synlig (eller usynlig, eller til og med ikke eksisterende for innlærere) når det ikke forekommer noen artikkel i substantivfrasen, eller er de nakne adjektivformene betraktet som default-former som er brukt når det ikke finnes noe (en trigger) i nominalfraser som tvinger innlæreren til å bøye adjektivet (utløser kongruens). Som sagt ovenfor, er jeg ikke i stand til å finne årsaken til feilene. Her er det fem eksempler på slike feil:

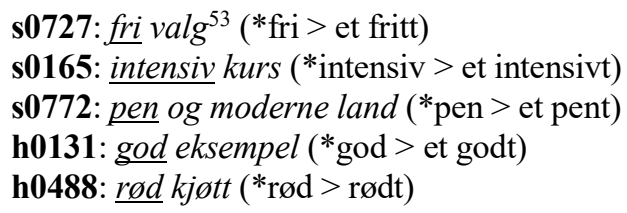

I predikativ stilling er den vanligste typen feil knyttet til determinativet det, og disse feilene beror på at adjektivet som står til det, ikke blir markert med endelsen - $t$. Det er til sammen 22 slike feil. 5 feil er forbundet med kongruens med noe og $h v a$ som er kontrollører til adjektivet. Feilene kan kanskje forklares med avstanden mellom predikativet og kontrolløren. Den er riktignok ikke stor, men den er større enn i nominalfraser, og kan derfor bidra til at man glemmer å samsvarsbøye adjektivet. Feilene kan også være en følge av at innlærere ikke vet at det, noe og hva som kontrollører krever nøytrumsformer av

${ }^{53}$ Informantenes ytringer er sitert i den formen det er tilstrekkelig til å se konteksten for samsvarsbøyning. Når en artikkel eller annen modifikator mangler i frasen, betyr det at den ikke var brukt av informanten. 
predikativer. Nedenfor presenteres det fem eksempler på slike feil:

s0164: det var slitsom (*slitsom > slitsomt)

s0800: det er god (*god > godt)

s0786: det er sikker (*sikker > sikkert)

h0646: det er plagsom (*plagsom > plagsomt)

h0195: blir det risikabel (*risikabel > risikabelt)

12 av feilene i denne kategorien er rene feil i kongruens siden adjektiver forblir ubøyd her mens substantivene får tildelt riktig genus (enten i form av en foranstilt eller en etterstilt artikkel, avhengig av frasetypen). Disse feilene kan være et tegn på at adjektivkongruens ikke hadde blitt tilegnet av informantene som gjorde dem. I dette tilfellet forekommer det verken et adjektiv som er spesielt problematisk og som brukes flere ganger feil (bare rik ble brukt to ganger mens resten av adjektivene ble brukt kun én gang hver) ${ }^{54}$, eller en spesielt problematisk kontrollør med hvilken adjektiver blir brukt flere ganger feil (bare samfunn brukes to ganger som en kontrollør med et ukorrekt bøyd adjektiv). På den annen side er de ganske få $\mathrm{i}$ forhold til alle feilene gjort $\mathrm{i}$ adjektivkongruens, og av den grunn kan de kanskje skyldes andre årsaker enn manglende kongruenskunnskaper (f.eks. slurv, stress). Nedenfor presenterer jeg alle disse 12 feilene:

s0734: et ny språket $\left({ }^{*}\right.$ ny $>$ nytt $)$

s0800: et snill ord $(* \text { snill }>\text { snilt })^{55}$

s0057: et stor problem (*stor > stort)

s0732: et solid grunnlag på engelsk var veldig hjelpsom

(*hjelpsom $>$ hjelpsomt)

h0031: et flerkulturrell samfunn (*flerkulturrell > flerkulturelt)

h0442: et stor ansvar (*stor $>$ stort)

h0618: et par er normal (*normal > normalt)

54 Jeg ser bort fra snill ettersom feilen med dette adjektivet er gjort to ganger av én og samme informant.

55 Informanten gjorde samme feil to ganger. 
h0474: matmarkedet i Norge er rik (*rik > rikt)

h0626: samfunnet er egentlig ganske rik (*rik $>$ rikt)

h0612: barnet er syk (*syk > sykt)

h0649: budskapet som er veldig klar (*klar $>$ klart)

Et par feil i denne kategorien gjelder for øvrig kongruensen med enten en infinitivfrase, eller med et subjekt med generisk referanse. Det forekommer imidlertid bare 3 slike feil i ASK, noe som kanskje kan skyldes det at slike fraser vurdert som vanskelige av innlærere, og generelt lite brukt av dem. Nedenfor presenterer jeg disse feilene:

h0473: idrett er populcer (*populær > populært)

h0071: å leie leilighet er $\underline{\mathrm{dyr}}\left({ }^{*} \mathrm{dyr}>\mathrm{dyrt}\right)$

h0633: likestilling er veldig populær (*populær $>$ populært)

Det er til sammen 47 ulike adjektiver som ikke ble markert med endelsen $-t$ i situasjoner når den grammatiske konteksten krevde bruken av denne endelsen. Tabell 30 viser disse adjektivene fordelt etter bøyningstypen. Som kan sees av tabellen, har de fleste adjektivene som ikke ble markert med endelsen $-t$ av de polskspråklige informantene, regelmessig bøyning, det vil si at nøytrumsformer dannes ved hjelp av hovedregelen - med å legge til - $t$ til adjektivstammen. Også adjektivene plassert $\mathrm{i}$ raden 'Med avvikende bøyning' bøyes $\mathrm{i}$ grunnen regelmessig. De kan imidlertid virke problematiske siden adjektiver på $-d$ får $-t$ i nøytrum avhengig av uttalen. Heller ikke adjektivene med såkalt modifisert bøyning ble markert med -t. Det kan altså sies at bøyningstype (enten regelmessig, eller modifisert, eller avvikende) ikke har stor innflytelse på hvorvidt informanten vil lykkes med å samsvarsbøye dette adjektivet. 


\begin{tabular}{|l|l|}
\hline Bøyningstype & Adjektiver \\
\hline $\begin{array}{l}\text { Regelmessig } \\
\text { (i samsvar med hoved- } \\
\text { regelen) }\end{array}$ & $\begin{array}{l}\text { attraktiv (2 ganger), dyr, ekstrem, frisk, } \\
\text { hvit, høy (2 ganger), intensiv, klar } \\
\text { (4 ganger), kostbar, lærerik, lang, lys, } \\
\text { mørk, nær, negativ, normal (2 ganger), pen }\end{array}$ \\
& $\begin{array}{l}\text { (2 ganger), populær (2 ganger), positiv } \\
\text { (3 ganger), respektløs, rik (2 ganger), stor } \\
\text { (12 ganger), syk, unormal }\end{array}$ \\
\hline $\begin{array}{l}\text { Med modifisert bøyning } \\
\text { (som ikke påvirker } \\
\text { - } t \text {-former) }\end{array}$ & $\begin{array}{l}\text { enkel, flerkulturell, hjelpsom (4 ganger), } \\
\text { morsom, plagsom, risikabel, sikker } \\
\text { (3 ganger), slitsom }\end{array}$ \\
\hline $\begin{array}{l}\text { Med modifisert bøyning } \\
\text { (som påvirker - } t \text {-former) }\end{array}$ & $\begin{array}{l}\text { betydningsfull, fri, full, meningsfull, ny, } \\
\text { snill (2 ganger), spesiell (3 ganger), sunn, } \\
\text { tynn, usunn, }\end{array}$ \\
\hline Med avvikende bøyning & bred, god (14 ganger), kald, rød, vond \\
\hline
\end{tabular}

Tabell 30: Adjektivene som ikke ble markert med endelsen -t av de polskspråklige informantene

Når det gjelder tilstedeværelsen av kontrollører i setningene laget av de polskspråklige informantene der de gjorde feil av typen 'mangel på - $t$-endelse', er de alltid til stedet, men kontrollørenes ordklasse varierer - vanligvis er de substantiver, med noen ganger er de også determinativer (først og fremst det) og pronomener (bl.a. $h v a$ ). Kontrollørens ordklasse ser altså ikke å ha påvirkning på at innlæreren lykkes i å identifisere konteksten for bruken av endelsen $-t$ eller ikke.

\subsubsection{Mangel på -e-endelse}

I predikativ stilling er alle de 49 feilene hvor de polskspråklige informantene utelot en -e-endelse hvor den var nødvendig, forbundet med å overse flertallskonteksten. Adjektivene referer til kontrollører i plural. Det som kan ha størst innflytelse på at informantene gjorde slike feil, er distansen mellom kontrolløren og adjektivet, noen ganger er det til med seks ord. De fleste kontrollørene er substantiver (bl.a. faktorer, barna, foreldrene), men det er også mange 
pronomener ( $v i, d e)$ og determinativer (alle). I 10 tilfeller er kontrollørene i grunnform selv om de har flertallsreferanse (disse kontrollørene er: barn, folk, ting). Feilene gjort med disse kontrollørene kan ha sin årsak $i$ at innlærerne ikke så flertallsreferansen i disse kontrollørene siden deres entalls- og flertallsformer ser like ut. Nedenfor presenterer jeg 8 eksempler på feil der det mangler en -e-endelse i predikativ stilling, og alle typene ovennevnte kontrollører er representert:

s0161: de voksne menneskene er veldig travel (*travel $>$ travle) s0939: enkeltepersoner kan bli mer fornuftig (*fornuftig > fornuftige)

h0131: folk føler seg utestengt og lite nyttig (*nyttig > nyttige)

s0785: ting som ikke er viktig (*viktig > viktig)

s0940: vi må vare veldig forsiktig (*forsiktig > forsiktig)

s0653: de føller seg så viktig (*viktig > viktig)

s0783: alle trenger å føle seg elskelig (*elskelig > elskelige)

s0762: alle var redd $(*$ redd $>$ redde)

I attributiv stilling forekommer det tre typer feil som resulterer i mangelen på endelsen $-e$, og den mest vanlige er knyttet til bruken av adjektiver i definitte fraser (det er 27 forekomster av slike feil - 44\%). I korpuset finnes det forekomster av manglende adjektivbøyning både når substantivet er bøyd i bestemt form korrekt og står med det korrekte demonstrativet (enten den, det, eller de) foran, når substantivet ikke får bestemt form, men demonstrativet står i riktig form, og når substantivet har korrekt form, men demonstrativet mangler. Det er imidlertid få (totalt 4) definitte fraser der det bare er adjektivet som er bøyd ukorrekt (og substantivet og demonstrativet korrekt). I de resterende 23 tilfeller viser nominalfrasene (bortsett fra selve adjektivene som er bøyd feil) avvik fra det som er korrekt i norsk. Bestemte fraser ser altså ut å skape problemer for de polskspråklige innlærerne. Nedenfor presenterer jeg tre eksempler på hvert 'korrekthetsnivå' i de omtalte frasene. 
s0765: den positiv siden (*positiv > positive)

h0081: den vakker naturen (*vakker > vakre)

h0583: den farlig siden (*farlig $>$ farlige)

h0657: den liten ting (*liten $>$ lille tingen)

h0345: det best ting ( ${ }^{*}$ best $>$ beste tingen)

h0347: det virkelig liv (*virkelig $>$ virkelige livet)

h0414: sterk viljen (*sterk $>$ den sterke)

h0141: polsk livet (*polsk $>$ det polske)

h0028: potensiell arbeidsløsheten (*potensiell $>$ den potensielle)

De to resterende typer feil som resulterer i mangelen på -eendelse, er manglende kongruens i flertallsreferansen (21 forekomster - $34 \%$ ), og manglende markering av adjektiver $\mathrm{i}$ genitivfraser (14 forekomster - $23 \%$ ). Når det gjelder feil i flertallsreferanser, skjer de både når kontrolløren er bøyd korrekt i pluralis (f.eks. organisasjoner, filmer), når kontrolløren står i pluralis, men denne formen er lik singularisformen (f.eks. ord, butikkbesøk), når kontrolløren er bøyd feil i pluralis (f.eks. forsjellse, personn), og når kontrolløren er utelatt (pga. f.eks. anafori, som i: Syk trenger hjelp ... $)^{56}$. Feil i flertallsreferansen kan kanskje forklares med at innlærerne overså eller misforsto kongruenskonteksten. Muligens spilte også andre faktorer en rolle i feilproduksjonen (f.eks. slurv, stress). I genitivfrasene er kontrollørene alltid bøyd riktig. Alle kontrollørene her står i entall, og har vanligvis et possessivpronomen foran. En gang er possessivpronomenet valgt ukorrekt (det er maskulint istedenfor nøytralt), ellers er de valgt korrekt. Bare to ganger er det brukt et substantiv i genitiv istedenfor et possessivpronomen. Mangel på adjektivbøyning $\mathrm{i}$ genitivfraser kan antakelig ha noe å gjøre med at slike fraser er $i$ en stor grad komplekse, og at adjektivet egentlig ikke samsvarer med kontrolløren når det gjelder tall og kjønn $\mathrm{i}$ genitivfraser. Av den grunn kan de betraktes som vanskelige av innlærerne, noe som fører til feil når de bruker dem. Nedenfor presenterer jeg noen av feilene:

${ }^{56}$ Setningen laget av informant nr. s0783. 
s0916: kort filmer (*kort > korte)

s0646: nøyaktig tester og tillatelser (*nøyaktig > nøyaktige)

h0473: dårlig matvaner (*dårlig > dårlige)

s0647: vannlig butikkbesøk (*vannlig > vanlige)

s0726: ingen norsk ord ( ${ }^{*}$ norsk $>$ norske)

s0755: min katolsk religion $\left({ }^{*}\right.$ katolsk $>$ katolske)

s0949: vår dårlig hølse (*dårlig > dårlige)

s0918: vår humanitcer forhold (*humanitær > humanitære)

h0639: sin egen nasjonal identitet (*nasjonal $>$ nasjonale)

h0176: pengers stor betydning (*stor $>$ store)

I de 111 tilfellene av manglende kongruens hvor språknormen krevde bruken av endelsen -e, ble det brukt 80 ulike adjektiver. Tabell 31 viser fordelingen av disse adjektivene etter graden i hvilken de er regelmessige. Som man ser i tabellen, hører 54 adjektiver (71\%) til klassen med modifisert bøyning der modifikasjon ikke påvirker -e-former, men kun - $t$-former. Disse adjektivene kan likevel oppfattes av innlærerne som ubøyelige (ettersom de ikke for endelsen $-t \mathrm{i}$ nøytrum), og det er kanskje grunnen til at de polskspråklige informantene unngikk å samsvarsbøye dem. 13 adjektiver er helt regelmessige, derfor kan det å gjøre feil i å samsvarsbøye dem tyde på at adjektivkongruens i norsk ikke er helt tilegnet av informantene som produserte disse feilene, eller at det forekom andre vanskeligheter i den grammatiske konteksten adjektivene ble brukt i, som førte til feil (f.eks. definitte fraser). 


\begin{tabular}{|l|l|}
\hline Bøyningstype & Adjektiver \\
\hline $\begin{array}{l}\text { Regelmessig } \\
\text { (i samsvar med hoved- } \\
\text { regelen) }\end{array}$ & $\begin{array}{l}\text { blank, enorm, hel, humanitær, nasjonal, } \\
\text { pen, positiv, slank, sosial, sterk, stor } \\
\text { (4 ganger), sur (2 ganger), syk (3 ganger) }\end{array}$ \\
\hline $\begin{array}{l}\text { Med modifisert bøyning } \\
\text { (som ikke påvirker } \\
\text {-e-former) }\end{array}$ & $\begin{array}{l}\text { ansvarlig, behagelig, best (3 ganger), } \\
\text { bevisst, daglig (2 ganger), desperat, } \\
\text { dårlig (4 ganger), eksotisk, elskelig, } \\
\text { engstelig, faglig, farlig, fast, fornuftig, } \\
\text { forsiktig (2 ganger), forskjellig, fri, } \\
\text { frivillig, katolsk, kjedelig, kort, kvinne- } \\
\text { lig, lydig, lykkelig, mest (2 ganger), } \\
\text { månedlig, norsk (3 ganger), nyttig } \\
\text { (2 ganger), nøyaktig, perfekt, personlig, } \\
\text { polsk (2 ganger), potensiell, praktisk, } \\
\text { privat, selvstendig (2 ganger), sint, snill } \\
\text { (2 ganger), tålmodig, teoretisk, trøtt, } \\
\text { tynn, typisk, uansvarlig, uavhengig, } \\
\text { uhøflig (2 ganger), uunngåelig, vanlig } \\
\text { (2 ganger), vanskelig, verdifull, viktig } \\
\text { (6 ganger), viktigst (3 ganger), virkelig, } \\
\text { ærlig }\end{array}$ \\
\hline $\begin{array}{l}\text { ensom (2 ganger), gammel, slem, travel, } \\
\text { vakker (2 ganger), åpen }\end{array}$ \\
\hline glad (4 ganger), liten (2 ganger), redd \\
\hline Med modifisert bøyning påvirker - $e$-former)
\end{tabular}

Tabell 31: Adjektivene som ikke ble markert med endelsen -e av de polskspråklige informantene

\subsubsection{Feil bruk av kongruens}

Den andre mest vanlige typen feil de polskspråklige informantene gjør, er å samsvarsbøye adjektiver i kontekster der det ikke er nødvendig. I korpuset forekommer det tilfeller der både $-e-$ og $-t$-endelsen er overbrukt. Tabell 32 viser antall forekomster av denne typen feil fordelt etter adjektivets funksjon i setningen. Det er også oppgitt relativt antall feil, det vil si prosent overbruken av samsvarsbøyning utgjør i forhold til alle feilene $i$ adjektivisk kongruens. De samme forholdene er også presentert i Diagram 14. 


\begin{tabular}{|c|c|c|c|c|}
\hline Feiltype & & $\begin{array}{l}\text { Overbruk } \\
\text { av } \\
-e \text {-endelse }\end{array}$ & $\begin{array}{l}\text { Overbruk } \\
\text { av } \\
-t \text {-endelse }\end{array}$ & SUM \\
\hline \multirow{2}{*}{$\begin{array}{l}\text { Attributiv } \\
\text { stilling }\end{array}$} & $\begin{array}{l}\text { Antall } \\
\text { forekomster }\end{array}$ & 31 & 38 & 69 \\
\hline & $\begin{array}{l}\% \text { av alle feil } \\
\mathrm{i} \text { adj.kongr. }\end{array}$ & 9,4 & 11,5 & 20,8 \\
\hline \multirow{2}{*}{$\begin{array}{l}\text { Predikativ } \\
\text { stilling }\end{array}$} & $\begin{array}{l}\text { Antall } \\
\text { forekomster }\end{array}$ & 26 & 24 & 50 \\
\hline & $\begin{array}{l}\% \text { av alle feil } \\
\mathrm{i} \text { adj.kongr. }\end{array}$ & 7,9 & 7,3 & 15,1 \\
\hline TOTALT & & $57(17,3 \%)$ & $62(18,8 \%)$ & $\begin{array}{l}119 \\
(36 \%)\end{array}$ \\
\hline
\end{tabular}

Tabell 32: Feil bruk av kongruens hos de polskspråklige informantene

\section{Antall feil av typen 'feil bruk av kongruens' i forhold til andre typer feil i kongruens}

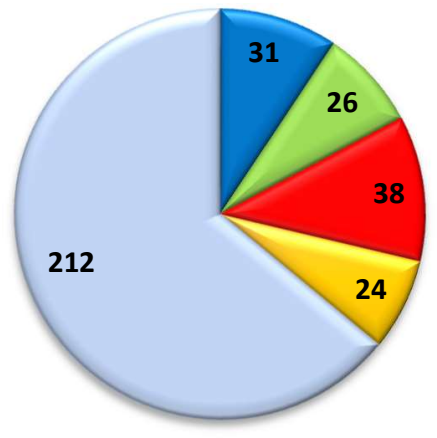

$\square$ Overbruk av eendelse i attr. pos.

$\square$ Overbruk av eendelse i pred. pos.

口Overbruk av tendelse i attr. pos.

$\square$ Overbruk av tendelse i pred. pos.

$\square$ Resten

Diagram 14: Ulike varianter av feil i 'feil bruk av kongruens' versus resterende typer feil $i$ kongruens gjort av de polskspråklige informantene (antall feil oppgitt $i$ absolutte tall) 


\subsubsection{Overbruk av -t-endelse}

Feil knyttet til overbruken av endelsen $-t$ ser ut å ha to årsaker. Enten dreier det seg om en utilstrekkelig tilegnelse av norsk kongruens (innlærere vet ikke hvor de skal bruke denne endelsen), eller (og det er kanskje det som er tilfellet i de fleste situasjonene) er adjektivets ukorrekte samsvarsbøyning forårsaket av ukorrekt assosiasjon når det gjelder kontrollørens kjønn. Det kan altså sies at adjektivet i disse situasjonene er bøyd korrekt, men på et feilaktig grunnlag. Problemet i denne forklaringen er at korpusdataene jeg står til rådighet med, ikke gir noen opplysninger angående informantenes motivasjon i å bruke denne endelsen og ikke en annen. Man vet ikke om det bare var kjønnet på substantivet (eller en annen type kontrollør) hun ikke visste, eller om det var samsvarsbøyningen hun ikke kunne godt, eller begge deler. Ganske ofte blir den ubestemte artikkelen utelatt, noe som kan tyde på at innlæreren ikke var helt sikker på kjønnet på substantivet. I attributiv stilling er det bare 6 eksempler på feil der adjektivet får en $-t$-endelse til et maskulint eller feminint substantiv med en foranstilt artikkel et. Det er 2 eksempler på feil i adjektivbøyning (når informanten brukte endelsen $-t$ ) hvor det er brukt en riktig foranstilt artikkel en til et maskulint eller feminint substantiv. Og det er ett eksempel på feil der det er brukt et adjektiv med bøyningsendelsen - $t$ til et substantiv med ukorrekt brukt bestemt form (både selve bruken av den bestemte formen var feil, og genusen substantivet fikk). I de resterende tilfellene feil i attributiv stilling (til sammen 29 forekomster av 38) er den foranstilte artikkelen utelatt. 1 gang forekommer det to adjektiver til én og samme kontrollør, og det ene er korrekt og det andre ukorrekt bøyd. Nedenfor presenterer jeg 6 eksempler på feil i overbruk av -t-endelse i attributiv stilling i kontekster hvor det ikke var bruk for noen adjektivendelse.

s0651: godt og sterk oppdragelse (*godt $>$ god)

s0727: et tøft tid (*tøft > en tøff)

h0123: en meget effektivt informasjonskilde (*effektivt $>$ effektiv) 
s0762: (han har nå) nyt urinblaeret (*nyt > en ny urinblære) s1005: spesielt hjelp $\left({ }^{*}\right.$ spesielt $>$ spesiell $)$

h0488: stort lyst (*stort > stor)

I predikativ stilling ser de fleste feilene ut til å være forbundet med at informantene 'glemte' hvilken genus kontrollørene var, og at de feilet i å identifisere konteksten til samsvarsbøyning riktig slik at de betraktet konteksten som om den krevde endelsen - $t$ mens den ikke gjorde det. Kanskje avstanden mellom kontrolløren og adjektivet påvirket innlærernes performanse. Dessuten forekommer det 4 eksempler på feil etter determinativet den, og 3 eksempler på feil med utelatt kontrollør som refererer til et menneske, noe som kan virke problematisk for innlærerne. 4 feil er gjort i forbindelse med verbet føle seg. Det kan tenkes påvirkning fra S1 polsk i disse tilfellene ettersom dette verbet i polsk krever et adjektiv bøyd adverbialt (eller et adverb), mens det i norsk krever samsvarsbøyning. 8 ganger er adjektivet bøyd ukorrekt selv om kontrolløren tydelig er markert for kjønn, og den står i bestemt form. Det er for øvrig 2 forekomster av feil med adjektivet sikker som står til et pronominell kontrollør (jeg, $d u$ ), og det er 2 forekomster av ukorrekt bøyde adjektiver som står til ubøyde maskuline substantiver (de står i ubøyd form uten noen artikler og andre modifikatorer). Det er ett eksempel på feil der konteksten for samsvarsbøyning i nøytrum var riktig identifisert, men adjektivet (viktig) var bøyd ukorrekt ettersom dette adjektivet ikke får endelsen - $t$. Nedenfor presenterer jeg de ovenfor omtalte feilene, og gir ett eksempel på hver av feiltypene:

h0635: den blir ikke så dyrt $(*$ dyrt $>$ dyr $)$

h0137: å voere trygt (*trygt $>$ trygg)

h0095: bør man ikke føle seg fritt $(*$ fritt $>$ fri)

s0061: vinteren er langt (*langt $>$ lang)

h0172: $d u$ er helt sikkert (*sikkert $>$ sikker)

s0745: tilstand hans er godt $\left({ }^{*}\right.$ godt $>$ god $)$

s0653: det er mest viktit (*viktit > viktig) 
I de 62 tilfellene hvor innlærerne overbrukte endelsen - $t$, anvendte de 41 ulike adjektiver, som er framstilt i Tabell 33. De fleste er regelmessige og med modifisert bøyning som imidlertid ikke påvirker bruken av -t-former. Den tekniske aspekten ved adjektivbøyning ser ut å være tilegnet - innlærerne klarte å bøye adjektivene stort sett korrekt (med noen få unntak der en informant bøyde viktig i nøytrum: viktit, en informant glemte å skrive dobbelt- $t$ i $n y$ : $n y t$, og en informant skrev spesielt med dobbel-l: spesiellt). Det som informantene fremdeles strever med, er å identifisere når en kontekst for samsvarsbøyning forekommer, og når den ikke forekommer. De 62 feilene som er blitt omtalt i denne underseksjonen, viser at det å identifisere en samsvarsbøyningskontekst ikke er helt tilegnet ennå.

\begin{tabular}{|l|l|}
\hline Bøyningstype & Adjektiver \\
\hline $\begin{array}{l}\text { Regelmessig } \\
\text { (i samsvar med hovedregelen) }\end{array}$ & $\begin{array}{l}\text { dyr, effektiv, fet, fin, full } \\
\text { (2 ganger), hel, lang (3 ganger), } \\
\text { lærerik, negativ, optimal, popu- } \\
\text { lær, positiv (2 ganger), ren, stor } \\
\text { (8 ganger), streng, total, tung, uklar }\end{array}$ \\
\hline $\begin{array}{l}\text { Med modifisert bøyning } \\
\text { (som ikke påvirker -t-former) }\end{array}$ & $\begin{array}{l}\text { enkel (2 ganger), fleksibel, laber, } \\
\text { morsom, oppmerksom, sikker } \\
\text { (2 ganger), åpen (2 ganger) }\end{array}$ \\
\hline $\begin{array}{l}\text { Med modifisert bøyning } \\
\text { (som påvirker - } t \text {-former) }\end{array}$ & $\begin{array}{l}\text { aktuell, fri, ny, seksuell, spesiell, } \\
\text { sunn (2 ganger), tøff, trygg } \\
\text { (4 ganger), usunn, viktig } \\
\text { (2 ganger) }\end{array}$ \\
\hline Med avvikende bøyning & god (6 ganger), liten \\
\hline
\end{tabular}

Tabell 33: Adjektivene som ble markert med endelsen -t av de polskspråklige informantene $i$ kontekster der det ikke var nødvendig

\subsubsection{Overbruk av -e-endelse}

De polskspråklige informantene gjorde til sammen 26 feil der de brukte - $e$-endelsen i predikativ stilling når det ikke forekom noen kontekst til å bruke denne endelsen. De fleste 
feilene (til sammen 18, noe som utgjør $69 \%$ alle feilene av denne typen) er knyttet til bruken av superlativformer. Det ser altså ut at informantene ikke helt hadde tilegnet regelen om at predikative adjektiver i superlativ ikke kan samsvarsbøyes. Bare 6 av feilene knyttet til superlativfraser finner sted når en kontrollør i flertall er til stedet (i slike tilfeller er bruken av -e bedre forklarlig ettersom det nettopp er kontrollører i flertall som danner konteksten til å bruke endelsen $-e$ ved de fleste adjektivene, med unntak av bl.a. adjektiver i superlativ) ${ }^{57}$. De resterende 12 kontrollørene er i singularis (en del av dem er infinitivfraser, og determinativer, først og fremst det). Her kan feilene kanskje forklares med at informantene ikke hadde tilegnet seg hvordan superlativformer kan brukes i predikativ stilling, det vil si at de kanskje blander adjektiviske predikativer (f.eks. det er viktigst) med nominalfraser som kan brukes som predikativer (f.eks. det er det viktigste). Også i dette tilfellet, er det kun en hypotese som ikke kan bekreftes med korpusdata. Nedenfor presenterer jeg 6 feil som er forbundet med overbruken av endelsen $-e$ i adjektiver i superlativ i predikativ posisjon:

50755: det er materielle verdier som er viktigste (*viktigste > viktigst)

h0442: guttene liker å være beste (*beste > best)

h0196: de første månedene og årene $\mathrm{i}$ barnets liv er viktigste (*viktigste $>$ viktigst)

s0766: det som er viktiste (*viktiste > viktigst)

h0196: hva skulle bli viktigste (*viktigste > viktigst)

h0535: det er egentlig det utseende som er viktigste (*viktigste > viktigst)

De resterende 8 feilene i predikativ stilling er stort sett vanskelige å forklare. De fleste ser ut å være tilfeldige. Tre ganger ble adjektiver brukt til en kontrollør i entall i bestemt form. En mulig forklaring til disse feilene er forskjellen i samsvarsbøyning av adjektiver med kontrollører i bestemt form

${ }^{57}$ Dette kan dessuten tyde på tverrspråklig innflytelse i dette tilfellet. 
i attributiv og predikativ funksjon. De får $-e$ kun i attributiv posisjon, og ikke i predikativ, noe som kan virke forvirrende for innlærere. Nedenfor presenterer jeg 3 eksempler på de resterende feilene:

s0983: for meg selv er mobiltelefonen nødvendige (*nødvendige $>$ nødvendig)

h0474: den tredje viktige grunnen til å være tykke $(*$ tykke $>$ tykk) s0758: men det var ikke så viktige (*viktige > viktig)

Overbruken av endelsen $-e$ i attributiv stilling kan i de fleste tilfellene ikke forklares annerledes enn med at innlærerne feilet i å identifisere konteksten for samsvarsbøyning. De så en kontekst der hvor den ikke var til stedet. Situasjonen som forekommer oftest her (28 av 31 feil), er at adjektivene med -e-endelsen blir brukt til kontrollører i entall. 8 ganger brukte informantene denne endelsen til en kontrollør i entall med en ubestemt artikkel, og 19 ganger til en kontrollør i entall ubestemt form uten noen artikler. 1 gang ble denne formen brukt til en kontrollør i bestemt form entall uten den foranstilte bestemte artikkelen. Bruken av den bestemte formen var i dette tilfellet også ukorrekt. Nedenfor presenterer jeg 6 eksempler på overbruk av $-e$-endelsen $i$ attributiv stilling:
s0761: en katolske familie (*katolske > katolsk)
s0786: ei lille telefonsbok (*lille > lita)
s0079: en riktige rettning (*riktige > riktig)
s0735: strenge oppdragelse (*strenge > streng)
h0112: norske lov (*norske > norsk)
h0196: nye teknologi (*nye > ny)

I de 57 tilfellene der feilene beror på å bruke -e-endelsen ukorrekt i kongruens, brukte informantene 33 ulike adjektiver. Adjektivet som er mest representert her er viktigst. Det ble brukt 14 ganger, og bare i predikativ funksjon. Siden adjektivet ikke ble anvendt med noen demonstrativ (f.eks. det), må det sies at det ble bøyd ukorrekt. Som man ser av Tabell 34, hører de fleste 
adjektivene til bøyning med modifikasjoner som imidlertid ikke gjelder bruken av - $e$-former. Informantene klarte å bøye disse adjektivene helt teknisk, men de enten overså eller misforsto samsvarsbøyningskonteksten slik at de trodde de skulle bøye disse adjektivene mens det ikke var nødvendig.

\begin{tabular}{|l|l|}
\hline Bøyningstype & Adjektiver \\
\hline $\begin{array}{l}\text { Regelmessig } \\
\text { (i samsvar med hovedregelen) }\end{array}$ & $\begin{array}{l}\text { negativ, positiv (2 ganger), } \\
\text { slank, stor, streng, ulik }\end{array}$ \\
\hline $\begin{array}{l}\text { Med modifisert bøyning } \\
\text { (som ikke påvirker - } e \text {-former) }\end{array}$ & $\begin{array}{l}\text { avhengig, best (3 ganger), } \\
\text { daglig, forskjellig, fremmed, } \\
\text { katolsk, lavest, nødvendig, } \\
\text { norsk (2 ganger), ny (3 ganger), } \\
\text { økonomisk, polsk, psykisk } \\
\text { (2 ganger), retorisk, rikest, } \\
\text { riktig, størst (2 ganger), } \\
\text { tradisjonell, tykk, viktig } \\
\text { (3 ganger), viktigst } \\
\text { (14 ganger), østlig }\end{array}$ \\
\hline $\begin{array}{l}\text { Med modifisert bøyning } \\
\text { (som påvirker - } e \text {-former) }\end{array}$ & ensom, voksen (3 ganger) \\
\hline Med avvikende bøyning & god, liten \\
\hline
\end{tabular}

Tabell 34: Adjektivene som ble markert med endelsen -e av de polskspråklige informantene $i$ kontekster der det ikke var nødvendig

\subsubsection{Feil bruk av kongruensendelse}

Blanding av kongruensendelsene, det vil si å bruke - $t$ istedenfor $-e$ og omvendt er en ganske sjelden feil hos de polskspråklige informantene. Det er til sammen 11 slike feil i korpuset, og Tabell 35 viser fordelingen av feilene i forhold til endelsene som ble brukt feil, og adjektivenes posisjon i setningene. Tabellen oppgir både totalantallet forekomster og prosenten feilene utgjør $\mathrm{i}$ forhold til alle feilene gjort av informantene i samsvarsbøyning. 


\begin{tabular}{|c|c|c|c|c|}
\hline Feiltype & & $\begin{array}{c}\text { Bruk av }-e \\
\text { istedenfor } \\
-t\end{array}$ & $\begin{array}{c}\text { Bruk av }-t \\
\text { istedenfor } \\
-e\end{array}$ & SUM \\
\hline \multirow{2}{*}{$\begin{array}{l}\text { Attributiv } \\
\text { stilling }\end{array}$} & $\begin{array}{l}\text { Antall } \\
\text { forekomster }\end{array}$ & 0 & 5 & 5 \\
\hline & $\begin{array}{l}\% \text { av alle feil } \\
\mathrm{i} \text { adj.kongr. }\end{array}$ & & 1,5 & 1,5 \\
\hline \multirow{2}{*}{$\begin{array}{l}\text { Predikativ } \\
\text { stilling }\end{array}$} & $\begin{array}{l}\text { Antall } \\
\text { forekomster }\end{array}$ & 1 & 5 & 6 \\
\hline & $\begin{array}{l}\% \text { av alle feil } \\
\mathrm{i} \text { adj.kongr. }\end{array}$ & 0,3 & 1,5 & 1,8 \\
\hline TOTALT & & $\begin{array}{l}1 \\
(0,3 \%)\end{array}$ & $\begin{array}{l}10 \\
(3 \%)\end{array}$ & $\begin{array}{l}11 \\
(3,3 \%)\end{array}$ \\
\hline
\end{tabular}

Tabell 35: Feil bruk av kongruensendelsene hos de polskspråklige informantene

Fordi det bare er 11 feil av denne typen, vil jeg sitere alle her:

s0770: livet er så enkle (*enkle > enkelt)

s0726: noen falskt ord (*falskt $>$ falske)

s0794: pent huset $(*$ pent $>$ det pene)

s0791: mest populcer middel (*populær $>$ det mest populære)

h0081: det godt livet (*godt $>$ gode)

h0026: deres hardt arbeid (*hardt $>$ harde)

s0654: vi mere åpent (*åpent $>$ åpne)

s0734: de føler seg dumt (*dumt $>$ dumme)

s0078: barn må føle seg trygt (*trygt $>$ trygge)

h0641: (kan vi) føle oss ensomt (*ensomt $>$ ensomme)

h0454: vi vil se godt ut ( ${ }^{*}$ godt $>$ gode)

Det som virker problematisk for informantene basert på disse utsagnene, er for det første adjektivbøyning i kongruens med kontrollørene som er i bestemt form, adjektivbøyning i superlativfraser og genitivfraser, og først og fremst samsvarsbøyning av adjektiver som forkommer sammen med verbene: føle seg og se ut. Som allerede nevnt, kan disse feilene 
ha noe med S1-innflytelse å gjøre. Begge verbene krever et adjektiv bøyd adverbialt (eller et adverb) i polsk, mens de i norsk krever samsvarsbøyning.

\subsubsection{Korrekt kongruensbøyning}

Andelen feil i kongruensbøyning gjort av de polskspråklige informantene utgjør 7,4\% av alle forekomster av adjektivisk samsvarsbøyning, og det betyr at informantenes korrekthet $\mathrm{i}$ performansen i norsk kongruensbøyning ligger på 92,6\%. De har altså performert korrekt 4119 ganger av 4450 (som er totalantallet forekomster av adjektivkongruens brukt av testtakerne). Man kan derfor si at adjektivisk samsvarsbøyning i norsk som S2 generelt sett er tilegnet av de polskspråklige informantene. I denne seksjonen vil jeg gi eksempler på korrekt bruk av samsvarsbøyning i de samme kategoriene som det er funnet feil i, og som er omtalt i seksjonene ovenfor. På denne måten vil jeg vise at det ikke bare er feilforekomster i disse kategoriene, noe som kunne tydet på at de er spesielt vanskelige å tilegne.

En ganske vanlig type feil gjelder nominalfraser der substantivet står i ubestemt form med en riktig tilpasset artikkel, men med et ukorrekt samsvarsbøyd adjektiv. I korpuset finnes det likevel flere eksempler på slike fraser der adjektiver er samsvarsbøyd korrekt. Her lister jeg opp 4 eksempler:

s0745: en veldig alvorlig sykdom

s0718: et fremmed språk

s0924: et godt program

h0645: en lys fremtid

En annen ganske vanlig type feil som gjelder nominalfraser, beror på å bruke et ukorrekt bøyd adjektiv til et substantiv i entall som står uten noen artikler. I ASK-korpuset er det flere eksempler på slike feilaktige nominalfraser, men med adjektiver som er bøyd i samsvar med substantivets genus: 
s0734: helt nytt språk

s0753: ny hytte

s0723: klukk og høflig mann

h0019: stort ansvar

Videre er en for så vidt kontroversiell (pga. av dens mulige forklaringsmåter) feil ganske vanlig i korpuset, nemlig den hvor informantene brukte nominalfraser med en ukorrekt tilpasset artikkel til substantivet, og med adjektivet ukorrekt bøyd til substantivet, men som samtidig var korrekt bøyd til artikkelen. Når man imidlertid søker etter en omvend situasjon, det vil si tilfeller når informantene samsvarsbøyde adjektivet korrekt $i$ forhold til substantivet, men artikkelen var ukorrekt tilpasset til substantivet (og derfor var adjektivet ikke i samsvar med artikkelen), forkommer det kun to slike fraser. Slike tilfeller er ikke betraktet som feil, ettersom det antas at det er substantivet som er kontrolløren for kongruens i nominalfraser. Likevel siden de nettopp omtalte frasene er så sjeldne i korpuset, tvinger de en til å stille spørsmålet om hva som egentlig utløser samsvarsbøyning: er det kontrolløren - substantivet, eller er det artikkelen? Basert på dataene fra ASK, vil jeg heller bøye meg for det andre alternativet, at det nettopp er artikkelen som er triggeren for adjektivisk samsvarsbøyning i nominalfraser. Det skal imidlertid oppfattes som en hypotese som trenger bevis. Det skal for øvrig tilføyes at det forekommer flere eksempler på feil i nominalfraser der artikkelen ikke passer til substantivet, men typen bøyning adjektivene som er brukt i disse frasene hører til, tillater ikke å legge til -t-endelsen i nøytrum, derfor er de tross alt korrekt brukt. Nedenfor presenterer jeg noen få eksempler på frasene som er omtalt her.

s0800: et liten prat

s0647: en veldig spesielt og interessant system

s0771: et psikisk hjelp

h0131: en fast beløp 
Også kontekster for flertallsbøyning i nominalfraser er flere ganger oversett slik at det oppstår feil der. Likevel er feil i kongruens i slike tilfeller bare en brøk av all bruken av denne strukturen, og mesteparten av bruken er korrekt. Nedenfor presenterer jeg kun noen få eksempler på korrekt samsvarsbøyning av adjektiver i substantivfraser i pluralis. Korrekt kongruens finner sted både når substantivet har en egen flertallsform, og når det ikke har det:

s0728: ulike måter

s0770: gamle dager

h0626: fine klær

h0369: store krav

h0662: vanlige brev

Definitte nominalfraser ser ut å være ganske problematiske for de polskspråklige informantene. De gjorde mange bøyningsfeil $\mathrm{i}$ dem, både når determinativet var brukt, og når det ikke var brukt, både når substantivet sto $\mathrm{i}$ bestemt form, og når det ikke gjorde det. Bortsett fra feil, finnes det også eksempler på korrekt samsvarsbøyning av adjektiver i definitte nominalfraser selv om selve frasene ikke alltid er korrekte:

h0068: den vanlige handelen

h0639: den raske globaliseringen

h0599: de unge arbeidstakkere

h0664: den norske statsminister

s0646: store problemet

s0658: nye teknologiene

Når det gjelder substantivfraser, oppsto det noen feil i samsvarsbøyning etter substantiver i genitiv og possessivpronomener - informantene 'glemte' - $e$-endelsen ved adjektiver i slike tilfeller. I korpuset finnes det imidlertid eksempler på korrekt kongruensbøyning i genitivfraser til tross for at selve frasene ikke alltid er korrekte. Dessuten er genitivfraser med adjektiver sjeldne i korpuset. Det er til sammen 52 slike fraser 
laget av de polskspråklige informantene hvorav 38 er korrekte. De fleste korrekte genitivfrasene inneholder adjektiver i superlativ (beste, rikeste, største, vanskeligste, verste - til sammen 12 forekomster), og adjektivet første (9 forekomster). I tillegg er de fleste genitivfrasene i flertall, noe som gjør det umulig å vurdere om det var genitivformen foran adjektivet eller substantivets flertallsform, som førte til at informantene brukte endelsen - $e$ korrekt. Det kan kanskje trekkes en konklusjon her at genitivfraser er problematiske og vanskelige for innlærere, og derfor er de unngått. Nedenfor presenterer jeg noen eksempler på genitivfrasene med korrekt bøyde adjektiver:

s0659: deres praktiske behover

s0955: vår lille samfunnet

h0096: kvinners intelektuelle kapasitet

h0629: sitt korte liv

h0335: verdens beste land

h0061: sitt første skritt

En vanlig feil i predikativ stilling beror på å overse konteksten for samsvarsbøyning både når substantiver og personlige pronomener som er kontrollører, er i flertall, nøytrum, og i maskulinum / femininum. Det samme gjelder determinativer (først og fremst det, men også alle, alt, noen, noe), og spørreordet hva. Det er likevel mange eksempler på korrekt bøyning av slike predikativer i korpuset, og her nevner jeg bare noen få av dem:

s0061: norske mennesker er hyggelige og hjelpsome

s0717: gruppen var liten

s0918: livet uten dem er mer trist og tomt

h0639: spørsmålet er aktuelt

s0955: alle sammen er vi enige

h0648: alt blir så veldig offisielt og stivt

s0978: hun er slank og ikke så høy

h0474: vi ble veldig passive

s0742: det er normalt

s0770: det er ikke rart 
h0172: må den være grønn

h0606: den ser litt verdiløs

s0055: noe som er svært verdifult

h0646: noe dyrt

s0783: noen er alvorlig syk

h0095: hva som er sant

s0723: hva er rett og galt

Videre er superlativer problematiske for de polskspråklige informantene, og de gjør feil i slike konstruksjoner. I korpuset er det imidlertid også eksempler på disse konstruksjonenes korrektbruk:

h0629: den største gleden

h0645: det dyreste landet

s0649: den beste måten

s0916: dette programmet er best

h0664: «ja-side» var sterkest

h0536: det som er viktigst

Det et noen få feil i korpuset som gjelder kongruens med enten en infinitivfrase eller med et subjekt med generisk referanse. Slike fraser er generelt sett ganske sjeldne i ASK (det finnes bare 7 tilfeller av korrekt samsvarsbøyning i generisk referanse, ett tilfelle av korrekt samsvarsbøyning i infinitivfrase, og ett i en at-setning $)^{58}$, og de kan oppfattes som kompliserte og vanskelige. Det er derfor sannsynlig at de ble unngått i tekstene testtakerne skrev. Dette er korrekte utsagn informantene produserte med slike fraser:

s0787: tekstmeldinger er veldig populart

h0028: netthandel er blitt så populært

s0955: en ting er klart

h0658: å skrive en melding er så populart

h0664: at det norske samfunnet er delt er sikkert

58 Tallene gjelder bare de adjektivene som kan få endelse - $t$. 
Det er også vist eksempler på transferlike feil der adjektiver ble adverbialt bøyd (de ble markert med - $t$-endelsen) etter verbene føle seg og se ut. Slike verbfraser forekommer veldig sjelden i korpuset: det er bare 18 tilfeller når samsvarsbøyning i slike verbfraser ble brukt korrekt, og det er 4 av forekomstene:

h0606: den ser litt verdiløs ut

s0742: en familie føler seg veldig ensom

s0794: ingen som føler seg ensom

h0081: mennesker føler seg små

\subsubsection{Oppsummering}

Samsvarsbøyning av adjektiver ser ut å være tilegnet generelt sett. Informantenes performanse samsvarer i de fleste tilfellene med det som betraktet som normen i norsk bokmål. Feilene som tross alt forekommer beror hovedsakelig på ikke å identifisere konteksten for adjektivisk samsvarsbøyning korrekt, det betyr å overse konteksten når den er til stedet, eller å se konteksten der den ikke er til stedet. Også er en del feil gjort hvor man rett og slett forveksler bøyningsendelsen. Det er noen konstruksjoner som virker vanskelige for informantene, og her må det først og fremst nevnes definitte fraser som er hyppige $\mathrm{i}$ informantenes tekster, men som ofte skaper problemer, ikke bare når det gjelder adjektivbøyning, men også substantivbøyning og bruken av determinativer. I tillegg forekommer det noen strukturer som også kan virke komplisert på teksttakerne, og derfor er de lite brukt, og tross det - ofte ukorrekt. Her vil jeg nevne først og fremst genitivfraser, kongruens med enten en infinitivfrase, med en at-setning eller med et subjekt med generisk referanse og i verbfrasene med verbene føle seg og se $u t$. De finnes ikke noen spesielt vanskelige adjektiver, som oftere enn andre skaper vansker for informantene. Testtakerne gjør feil både i adjektiver med regelmessig bøyning, og med modifisert og avvikende bøyning. Det er altså ikke det tekniske aspektet ved samsvarsbøyningen som fører til feil, men heller den grammatiske konteksten. Årsaken til en del feil kan ikke 
forklares med den datatypen som er brukt i denne oppgaven ettersom det ofte vil kreve undersøkingen av informantenes motivasjon til å bruke den gitte bøyningsendelsen. Noen feil har sikkert oppstått tilfeldig, som er resultat av hastighet, slurv eller stress.

\subsection{Påvirkning av sosiale faktorer på de polskspråkliges performanse i norsk samsvarsbøyning}

I dette underkapittelet skal jeg undersøke hvorvidt sosiale faktorer påvirker de polske norskinnlærernes performanse $\mathrm{i}$ samsvarsbøyning av norske adjektiver. Jeg skal se på seks typer faktorer som jeg betegner som 'sosiale' i bred betydning. Disse faktorene er: generelle norskkunnskaper (målt i CEFR-nivåer), alder, utdanning, antall kurstimer i norsk, oppholdstid i Norge, kunnskaper i engelsk som S3. For å måle innflytelsen av faktorene bruker jeg Kruskal-Wallis-testen, og i tilfellet statistisk signifikant resultat bruker jeg dessuten Mann-Whitney-testen som en post-hoc test for å sjekke hvor nøyaktig den signifikante forskjellen ligger. Ved bruk av Mann-Whitney-testen er også Bonferroni-korrigering anvendt. I tilfellet faktorene: utdanning og antall kurstimer i norsk anvendes Kruskal-Wallis-testen ikke ettersom det bare er to variabler som sammenlignes der. Av den grunn er kun Mann-Whitney-testen anvendt uten Bonferroni-korrigering (fordi testen er brukt bare én gang).

\subsubsection{Generelle S2-kunnskaper}

Fordi tekstene informantene skrev, er besvarelser på to språktester: Språkprøven og Bergenstesten (den første måler språkkunnskaper på B1-nivå, og den andre - på B2-nivå), er også CEFR-spekteret vidt $\mathrm{i}$ dataene. Informantenes tekster er plassert på nivå fra $\mathrm{A} 2$ til $\mathrm{C} 1$. Tabell 36 viser fordelingen av nivåene blant de polske norskinnlærerne, som også er illustrert i Figur 3. 


\begin{tabular}{|l|l|l|l|l|l|l|l|}
\hline CEFR-nivå & $\mathrm{A} 2$ & $\mathrm{~A} 2 / \mathrm{B} 1$ & $\mathrm{~B} 1$ & $\mathrm{~B} 1 / \mathrm{B} 2$ & $\mathrm{~B} 2$ & $\mathrm{~B} 2 / \mathrm{C} 1$ & $\mathrm{C} 1$ \\
\hline $\begin{array}{l}\text { antall } \\
\text { informanter }\end{array}$ & 2 & 25 & 42 & 52 & 58 & 16 & 5 \\
\hline
\end{tabular}

Tabell 36: Fordeling av CEFR-nivåer blant de polskspråklige norskinnlcererne $(N=200)$

\section{Fordelingen av CEFR-nivåene i norsk som S2 hos de S1-polskspråklige}

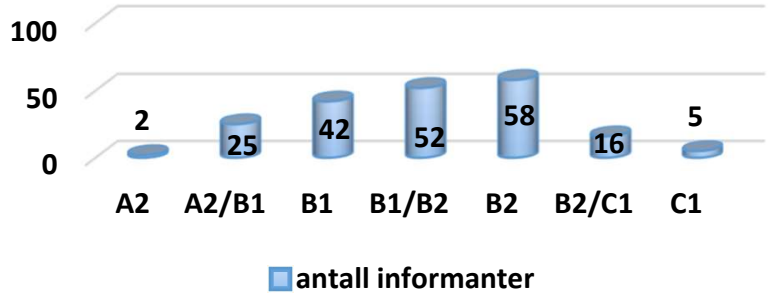

Figur 3: Fordeling av CEFR-nivåer i norsk som S2 blant de polskspråklige norskinnlcererne $(N=200)$

Ettersom ekstremverdiene er små, har jeg slått dem sammen med de nærmeste verdiene slik at A2-nivået er blitt slått sammen med $\mathrm{A} 2 / \mathrm{B} 1$-nivået, og $\mathrm{C} 1$-nivået er blitt slått sammen med B2/C1-nivået $\mathrm{i}$ denne analysen (etter denne operasjonen er det altså 27 informanter på A2/B1-nivået og 21 informanter på B2/C1-nivået). Tabell 37 viser antall feil i adjektivkongruens gjort av de polskspråklige norskinnlærerne fordelt etter CEFR-nivåene. Den første raden i tabellen viser antall informanter på det gitte nivået, den tredje raden viser gjennomsnittsantallet feil, den fjerde - medianen, den femte standardavviket, den sjette - det minste antallet feil gjort av minst én person i den gitte gruppen (nuller i denne raden viser at det var noen feilfrie tekster på hvert nivå), og den sjuende raden viser det største antallet feil gjort av minst én informant $\mathrm{i}$ den gitte CEFR-gruppen. Den nest siste raden viser antallet tekster der det ikke ble gjort noen feil, og den siste raden viser 
totalantallet feil i adjektivisk samsvarsbøyning. I de fleste tilfellene (der det er rimelig) oppgis det to tall: totalantallet forekomster av feil i adjektivisk samsvarsbøyning og relativt antall feil i adjektivisk samsvarsbøyning (dvs. antall feil delt på antall forekomster av adjektivkongruens). De samme forholdene som i Tabell 37 er også illustrert i Figur 4.

\begin{tabular}{|c|c|c|c|c|c|c|c|c|c|c|}
\hline \multirow[t]{2}{*}{ CEFR-nivå } & \multicolumn{2}{|c|}{$\begin{array}{c}\mathbf{A 2} / \mathbf{B 1} \\
(\mathbf{N}=27)\end{array}$} & \multicolumn{2}{|c|}{$\begin{array}{c}\text { B1 } \\
(\mathrm{N}=42)\end{array}$} & \multicolumn{2}{|c|}{$\begin{array}{c}\mathrm{B} 1 / \mathrm{B} 2 \\
(\mathrm{~N}=52)\end{array}$} & \multicolumn{2}{|c|}{$\begin{array}{c}\text { B2 } \\
(N=58)\end{array}$} & \multicolumn{2}{|c|}{$\begin{array}{c}\mathrm{B} 2 / \mathrm{C} 1 \\
(\mathrm{~N}=\mathbf{2 1})\end{array}$} \\
\hline & 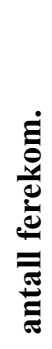 & 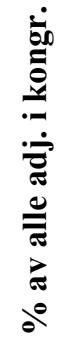 & 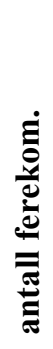 & 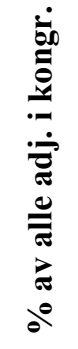 & 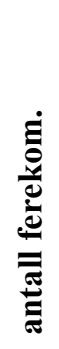 & 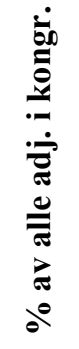 & 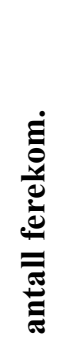 & 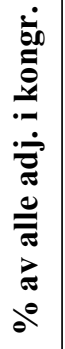 & 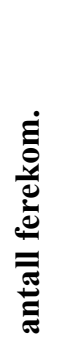 & 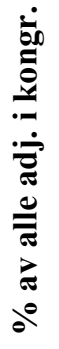 \\
\hline Gje & 2 & 15 & 1,5 & 11,8 & 1 & 7,8 & 1 & 5,8 & 1 & 5 \\
\hline Median & 2 & 11,1 & 1,8 & 8,9 & 1,7 & 7,4 & 1,6 & 5,2 & 1 & 3 \\
\hline \begin{tabular}{|l} 
Std. avvik. \\
\end{tabular} & 1,6 & 14,1 & 1,6 & 10,4 & 1,5 & 6 & 1,6 & 5,5 & 1 & 3,1 \\
\hline Min. & 0 & 0 & 0 & 0 & 0 & 0 & 0 & 0 & 0 & 0 \\
\hline Maks. & 5 & 55,6 & 7 & 43,8 & 6 & 23,5 & 6 & 24 & 3 & 9,5 \\
\hline \begin{tabular}{|l|}
$\mathrm{N}$ tekster \\
med $0 \%$
\end{tabular} & 5 & & 10 & & 13 & & 17 & & 8 & \\
\hline TOTALT & 53 & & 75 & & 89 & & 94 & & 20 & \\
\hline
\end{tabular}

Tabell 37: Feil i adjektivkongruens etter CEFR-nivå gjort av de polskspråklige informantene 


\section{Relativt antall feil i adjektivisk samsvarsbøyning etter CEFR-nivå}

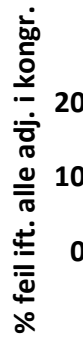

15

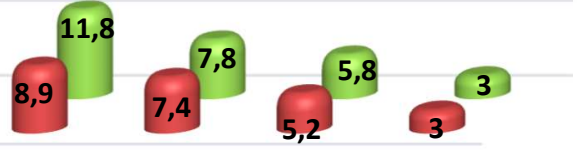

11,1

B1

B1/B2

B2

B2/C1

amedian $\square$ gjennomsnitt

Figur 4: Relativt antall feil i adjektivisk samsvarsbøyning etter CEFR-nivå gjort av de polskspråklige informantene

Ved hjelp av Kruskal-Wallis-testen har jeg sjekket om antallet feil i adjektivisk samsvarsbøyning i norsk som S2 avhenger av informantenes CEFR-nivået i S2-norsk. Resultatet fra denne testen viser at forskjellene i fordelingen av CEFRnivåene hos de polskspråklige informantene er statistisk signifikante $\left(X^{2}=25,2066, d f=4, p<0,001 * * *\right)$. For å se hvor nøyaktig de statistisk signifikante forskjellene ligger, har jeg gjennomført Mann-Whitney-testen med Bonferroni-korrigering.

Tabell 38 viser resultatene fra denne testen der hvert par av nivåene var testet separat. I den øvre-høyre delen av Tabell 38 viser cellene resultatet fra testen for hvert par. I parenteser er p-verdien etter Bonferroni-korrigeringen. Den nedre-venstre delen av Tabell 38 viser signifikansnivået. Resultatet er statistisk signifikant når $\mathrm{p}$-verdien er mindre enn 0,05 . I tilfellene når det oppstår en statistisk signifikant forskjell, er cellen markert med farge. 


\begin{tabular}{|c|c|c|c|c|c|}
\hline $\begin{array}{c}\text { Mann- } \\
\text { Whitney- } \\
\text { testen } \\
\text { (Bonferoni) }\end{array}$ & A2/B1 & B1 & B1/B2 & B2 & B2/C1 \\
\hline$A 2 / B 1$ & & $\begin{array}{c}\mathrm{W}=623 \\
\mathrm{p}-\mathrm{value}= \\
0,4926 \\
(2,463)\end{array}$ & $\begin{array}{c}\mathrm{W}=891 \\
\mathrm{p}-\mathrm{value}= \\
0,04994 \\
(0,2497)\end{array}$ & $\begin{array}{c}\mathrm{W}=1102 \\
\mathrm{p}-\mathrm{value}= \\
0,002421 \\
(0,012105)\end{array}$ & $\begin{array}{l}\mathrm{W}=454,5 \\
\mathrm{p} \text {-value }= \\
0,0003444 \\
(0,001722)\end{array}$ \\
\hline B1 & $p>0,05$ & & $\begin{array}{c}\mathrm{W}=1307,5 \\
\mathrm{p} \text {-value }= \\
0,09945 \\
(0,49725)\end{array}$ & $\begin{array}{c}\mathrm{W}=1639,5 \\
\mathrm{p} \text {-value }= \\
0,00298 \\
(0,0149)\end{array}$ & $\begin{array}{c}W=679 \\
\text { p-value }= \\
0,0004572 \\
(0,002286)\end{array}$ \\
\hline$B 1 / B 2$ & $p>0,05$ & $p>0,05$ & & $\begin{array}{c}W=1809,5 \\
p \text {-value }= \\
0,06861 \\
(0,34305)\end{array}$ & $\begin{array}{c}\mathrm{W}=804,5 \\
\mathrm{p} \text {-value }= \\
0,00146 \\
(0,0073)\end{array}$ \\
\hline$B 2$ & $p<0,05^{*}$ & $p<0,05^{*}$ & $p>0,05$ & & $\begin{array}{c}W=777 \\
\mathrm{p} \text {-value }= \\
0,05887 \\
(0,29435)\end{array}$ \\
\hline$B 2 / C 1$ & $p<0,01 * *$ & $p<0,01 * *$ & $p<0,01 * *$ & $p>0,05$ & \\
\hline
\end{tabular}

Tabell 38: Korrelasjonen mellom antallet feil $i$ adjektivisk samsvarsbøyning $i$ norsk og CEFR-nivå i $S 2$ norsk hos S1-polskspråklige; resultater fra Mann-

Whitney-testen med Bonferroni-korrigering

Som man kan lese av Tabell 38, er det en statistisk signifikant forskjell $\mathrm{i}$ antallet feil i adjektivkongruens i S2-norsk mellom informantene på B2-nivået og $\mathrm{A} 2 / \mathrm{B} 1 \mathrm{og} \mathrm{B} 1\left(\mathrm{p}<0,05^{*}\right)$, og mellom informantene på $\mathrm{B} 2 / \mathrm{C} 1$-nivået og $\mathrm{A} 2 / \mathrm{B} 1$ $\left(\mathrm{p}<0.01^{* *}\right), \mathrm{B} 1\left(\mathrm{p}<0.01^{* *}\right) \operatorname{og} \mathrm{B} 1 / \mathrm{B} 2\left(\mathrm{p}<0.01^{* *}\right)$. Det kan altså sies at det er et generelt trekk $\mathrm{i}$ de polskspråklige norskinnlærernes mellomspråk at de giør færre feil i adjektivisk samsvarsbøyning på B2-nivå og oppover enn på B1-nivå og nedover. Diagram 15 viser korrelasjonen mellom det relative 
antallet feil i adjektivkongruens (dvs. totalantallet feil delt på antallet forekomster av adjektivkongruens) og CEFR-nivåene.

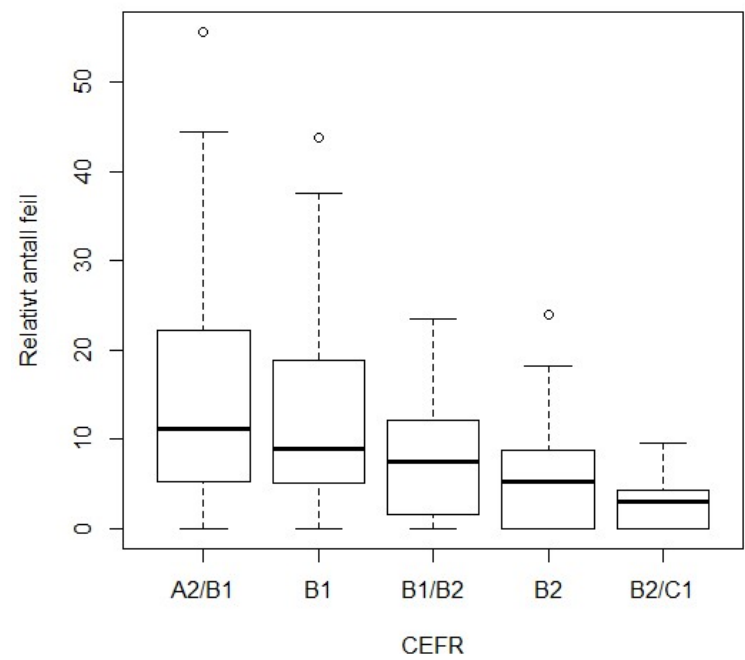

Diagram 15: Korrelasjonen mellom antallet feil i adjektivkongruens og CEFRnivå i S2-norsk hos S1-polskspråklige informantene

\subsubsection{Alder}

Den andre faktoren jeg skal teste påvirkning på performansen i adjektivkongruens i S2-norsk av, er alder. Den yngste polskspråklige testtakeren er 19 år, og den eldste - 54 år. Medianen er på 29 år, og gjennomsnittet ligger på 30,83 år. For å bringe mer klarhet og for å kunne gjennomføre statistiske tester, har jeg slått sammen alderen til informantene med samme titall år. Slik er personer fra for eksempel 20 til 29 tatt sammen til én gruppe. Tabell 39 presenterer antallet personer i hver aldersgruppe. 


\begin{tabular}{|l|c|c|c|c|c|}
\hline Alder & $18-19$ år & $20-29$ år & $30-39$ år & $40-49$ år & $50-54$ år \\
\hline $\begin{array}{l}\text { antall } \\
\text { informanter }\end{array}$ & 1 & 104 & 70 & 23 & 2 \\
\hline
\end{tabular}

Tabell 39: De polske informantenes alder

Siden ekstremverdiene er små, er de i statistiske tester slått sammen med de nærmeste verdiene. Slik er den 19 år gamle informanten inkludert i gruppen sammen med de 20-29 år gamle, og de to 50-54 år gamle informantene er i gruppen sammen med de som er 40-49 år. Tabell 40Figur 12 viser fordelingen av feil i adjektivisk samsvarsbøyning i S2-norsk gjort av de polskspråklige informantene. Den første raden viser antallet informanter $i$ hver aldersgruppe. Informantene $i$ alderen 19-29 år utgjør den største gruppen (105 personer), mens innlærerne i alderen 40-54 år utgjør den minste gruppen (25 personer). Informantene $i$ alderen 30-39 år danner en mellomstor gruppe med 70 personer. Den tredje raden i tabellen viser gjennomsnittsantallet feil, den fjerde - medianen, den femte - standardavviket. Den sjette raden viser det minste antallet feil gjort av minst én informant (fordi det $\mathrm{i}$ hver aldersgruppe var flere informanter som ikke gjorde noen feil i samsvarsbøyning, er minimumsverdien lik null), den sjuende raden viser det største antallet feil gjort av minst én informant. Hver gang er det oppgitt to tall: totalantallet forekomster av feil og det relative antallet feil beregnet $i$ forhold til alle kongruensbøyde adjektiver. Den nest siste raden viser antallet tekster hvor det ikke ble gjort noen feil i adjektivkongruens, og den siste raden viser totalantallet feil gjort av alle informantene i den gitte aldersgruppen. 


\begin{tabular}{|c|c|c|c|c|c|c|}
\hline Alder & \multicolumn{2}{|c|}{$19-29$ år $(\mathrm{N}=105)$} & \multicolumn{2}{|c|}{ 30-39 år $(\mathrm{N}=70)$} & \multicolumn{2}{|c|}{$40-54$ år $(\mathrm{N}=25)$} \\
\hline & 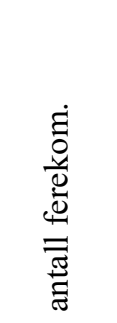 & 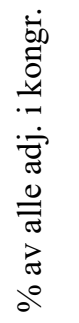 & 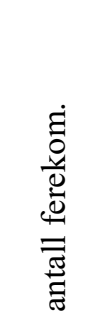 & 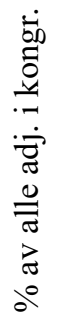 & 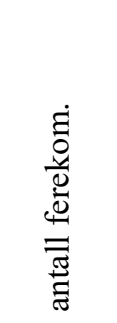 & 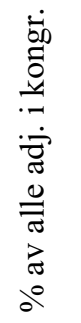 \\
\hline Gjennomsn. & 1,6 & 8,4 & 1,9 & 9,8 & 1,2 & 5,3 \\
\hline Median & 1 & 6,7 & 1 & 7,8 & 1 & 3,4 \\
\hline Std.avvik & 1,4 & 9,1 & 1,6 & 9,4 & 1,5 & 6,5 \\
\hline Min. & 0 & 0 & 0 & 0 & 0 & 0 \\
\hline Maks. & 7 & 44,4 & 6 & 55,6 & 6 & 21,4 \\
\hline $\begin{array}{l}\mathrm{N} \text { tekster } \\
\text { med } 0 \%\end{array}$ & 28 & & 14 & & 11 & \\
\hline TOTALT & 172 & & 130 & & 29 & \\
\hline
\end{tabular}

Tabell 40: Feil i adjektivkongruens etter aldersgruppe gjort av de polskspråklige informantene

Resultatet fra Kruskal-Wallis-testen viser at det finnes en korrelasjon mellom antallet feil i adjektivkongruens og alder $\left(X^{2}=6,3429, d f=2, p<0,05^{*}\right)$. En statistisk signifikant forskjell i antallet feil er mellom de 30-39 år gamle informantene og de $40-54$ år gamle $\left(W=1157,5, p<0,05^{*}\right)^{59}$. De yngre gjør signifikant flere feil i adjektivkongruens enn de eldre. Det finnes ingen statistisk signifikante mellom de to øvrige parene (19-29 år - 30-39 år: $W=3251, p>0,05,19-29$ år - 40-54 år: $W$ $=1612,5, p>0,05)^{60}$. Figur 5 illustrerer disse forholdene.

${ }^{59}$ Mann-Whitney-testen med Bonferroni-korrigering.

${ }^{60}$ Mann-Whitney-testen med Bonferroni-korrigering. 


\section{Relativt antall feil i adjektivisk samsvarsbøyning for alder}

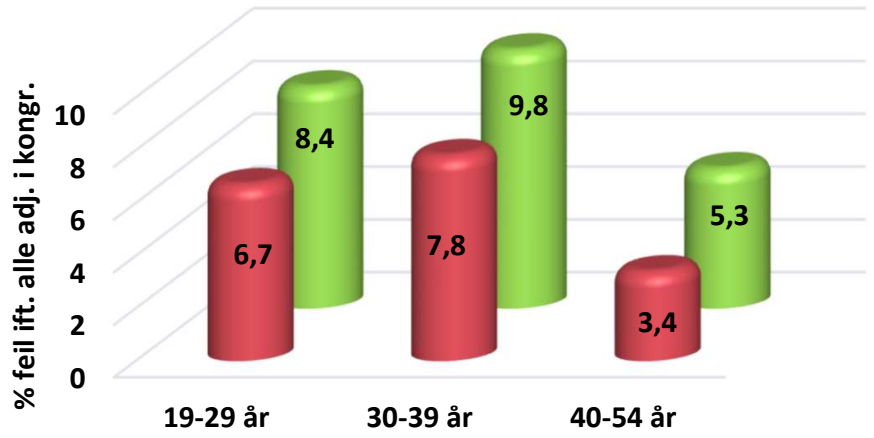

Median $\square$ gjennomsnitt

Figur 5: Relativt antall feil i adjektivisk samsvarsbøyning for alder

\subsubsection{Utdanning}

Utdanningsnivået er en annen faktor som kan ha innflytelse på andrespråkslæring. De fleste polske informantene har høyere utdanning (79\%), og de resterende har videregående utdanning (40\%). To personer (1\%) har ikke oppgitt sitt utdanningsnivå. Tabell 41 viser det totale og relative antallet feil i norsk adjektivkongruens gjort av de polskspråklige informantene. Tabellen har samme oppbygging som blant annet Tabell 40 ovenfor, og viser antallet informanter i hver sammenligningsgruppe, gjennomsnittet, medianen, standardavviket, det minste og største antallet feil gjort i minst én tekst, antallet tekster med ingen feil og totalantallet feil gjort av alle informantene på det samme utdanningsnivået. 


\begin{tabular}{|c|c|c|c|c|}
\hline Utdanningsnivå & \multicolumn{2}{|c|}{ Videregående $(\mathrm{N}=40)$} & \multicolumn{2}{|c|}{ Høyere $(\mathrm{N}=158)$} \\
\hline & 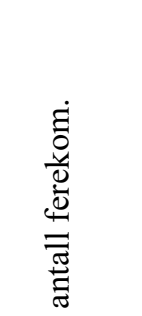 & 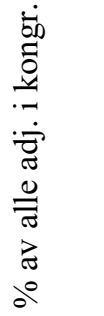 & 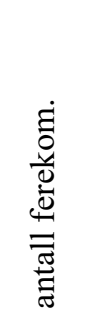 & 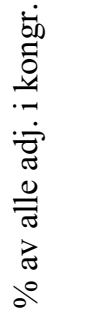 \\
\hline Gjennomsn. & 1,7 & 7,7 & 1,7 & 8,7 \\
\hline Median & 1 & 6,7 & 1 & 6,7 \\
\hline Std.avvik & 1,6 & 6,9 & 1,5 & 9,5 \\
\hline Min. & 0 & 0 & 0 & 0 \\
\hline Maks. & 6 & 24 & 7 & 55,6 \\
\hline $\begin{array}{l}\mathrm{N} \text { tekster } \\
\text { med } 0 \%\end{array}$ & 4 & & 49 & \\
\hline TOTALT & 67 & & 264 & \\
\hline
\end{tabular}

Tabell 41: Feil i adjektivkongruens etter utdanningsnivå gjort av de polskspråklige informantene

For å teste om forskjellene $\mathrm{i}$ antall feil i adjektivisk samsvarsbøyning i S2 norsk som de polske testtakerne på de ulike utdanningsnivåene gjorde, har jeg gjennomført MannWhitney-testen ettersom det bare var to sammenligningsgrupper. Testen viste ingen statistisk signifikans $(W=3081$, $p>0,05$ ), noe som betyr at utdanningsnivået ikke har noen påvirkning på performansen i norsk samsvarsbøyning hos de polskspråklige informantene. Figur 6 illustrerer det relative antallet feil i adjektivkongruens (dvs. antallet feil i kongruens $\mathrm{i}$ forhold til alle kongruensbøyde adjektiver) fordelt etter utdanningsnivået. 


\section{Relativt antall feil i adjektivisk samsvarsbøyning etter utdanningsnivået}

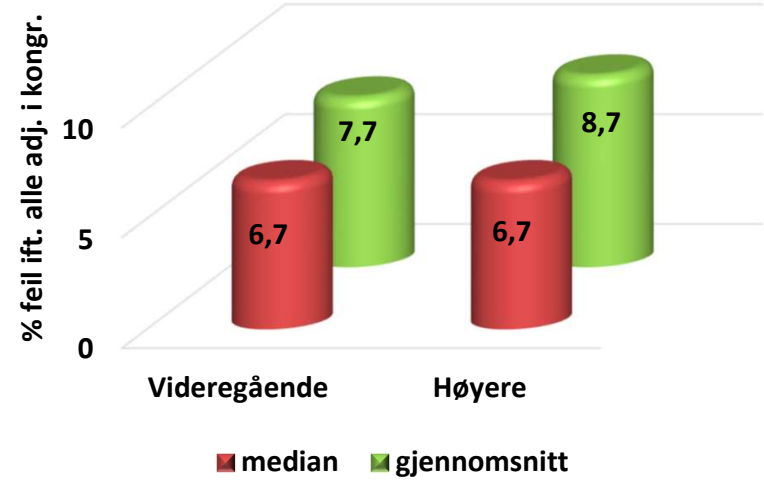

Figur 6: Relativt antall feil $i$ adjektivisk samsvarsbøyning etter utdanningsnivået gjort av de polskspråklige informantene

\subsubsection{Antall kurstimer i norsk}

Antallet kurstimer er en annen variabel som muligens påvirker performansen i S2-norsk samsvarsbøyning av adjektiver. I ASK er det tilgang til opplysninger om antall kurstimer i norsk bare $\mathrm{i}$ forhold til testtakerne som tok Språkprøven, og ikke en gang alle av dem har oppgitt denne informasjonen. Informantene kunne oppgi antall kurstimer i følgende intervallene: 0-200 timer, 201-400 timer, 401-500 timer, 501-850 timer, 851-1500 timer og 1501-2000 timer. Det siste intervallet forekommer ikke i den polskspråklige gruppen, derfor ble det sett bort fra. Tabell 42 viser hvor mange av de polskspråklige informantene som hadde gått hvor lenge på norskkurs. 


\begin{tabular}{|l|c|c|c|c|c|c|}
\hline $\begin{array}{l}\text { Antall } \\
\text { kurstimer } \\
\text { i norsk }\end{array}$ & $0-200$ & $201-400$ & $401-500$ & $501-850$ & $851-1500$ & ukjent \\
\hline $\begin{array}{l}\text { Antall } \\
\text { informanter }\end{array}$ & 7 & 40 & 16 & 25 & 2 & 10 \\
\hline
\end{tabular}

Tabell 42: Antall kurstimer i norsk de polskspråklige norskinnlaererne har tatt før Språkprøven $(N=100)$

Ettersom tidsintervallene er mange, og verdiene de inneholder er små, har jeg bestemt meg for å slå dem sammen til to grupper: opptil 400 timer og over 400 timer. Disse to gruppene har jeg testet med Mann-Whitney-testen for hvorvidt forskjellene $\mathrm{i}$ antall feil i norsk adjektivkongruens påvirkes av antallet timer informantene hadde gått på norskkurs. Tabell 43 viser gruppeforskjellene. Den har samme oppbygging som for eksempel Tabell 40 ovenfor, og inneholder antallet informanter i hver gruppe, gjennomsnittet, medianen, standardavviket, det minste og største antallet feil gjort av minst én informant, antallet tekster med ingen feil og totalantallet feil. Verdiene er oppgitt $\mathrm{i}$ absolutte tall (dvs. det virkelige antallet feilforekomster) og $\mathrm{i}$ forhold til alle kongruensbøyde adjektiver $\mathrm{i}$ tekstene. Figur 7 illustrerer de samme forholdene. 


\begin{tabular}{|c|c|c|c|c|}
\hline $\begin{array}{l}\text { Antall } \\
\text { kurstimer i norsk }\end{array}$ & \multicolumn{2}{|c|}{$0-400(\mathrm{~N}=47)$} & \multicolumn{2}{|c|}{$401-1500(\mathrm{~N}=43)$} \\
\hline & 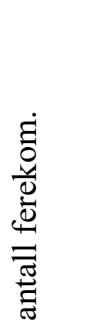 & 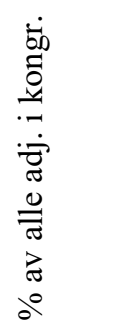 & 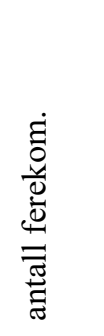 & 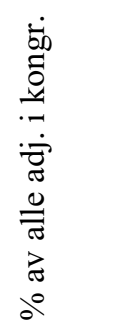 \\
\hline Gjennomsn. & 1,6 & 11,1 & 1,6 & 10,8 \\
\hline Median & 1 & 8,3 & 1 & 7,7 \\
\hline Std.avvik & 1,5 & 10,9 & 1,5 & 11,5 \\
\hline Min. & 0 & 0 & 0 & 0 \\
\hline Maks. & 5 & 55,6 & 7 & 44,4 \\
\hline $\begin{array}{l}\mathrm{N} \text { tekster } \\
\text { med } 0 \%\end{array}$ & 12 & & 12 & \\
\hline TOTALT & 76 & & 67 & \\
\hline
\end{tabular}

Tabell 43: Feil i adjektivkongruens etter antallet kurstimer de polske informantene har tatt før Språkprøven

Mann-Whitney-testen viste at de forskjellene som finnes $\mathrm{i}$ antallet feil i adjektivisk samsvarsbøyning, ikke er statistisk signifikante $(W=965, p>0,05)$. Det viser seg altså at antallet kurstimer i målspråket ikke har noen påvirkning på performansen i adjektivisk samsvarsbøyning i norsk som andrespråk. 


\section{Relativt antall feil i adjektivisk samsvarsbøyning etter antallet norsktimer}

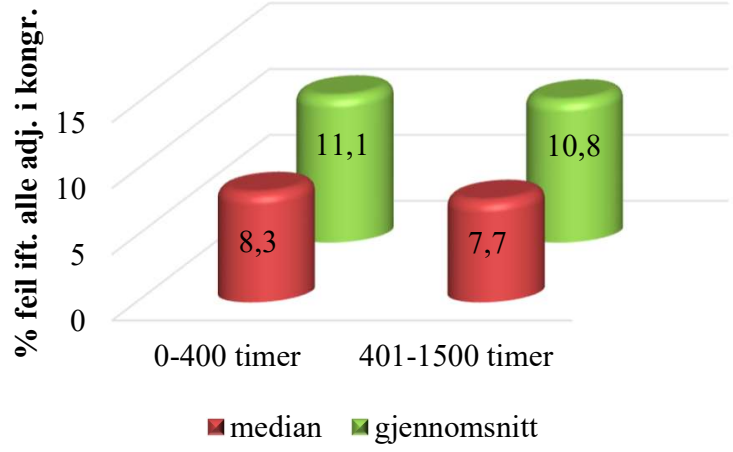

Figur 7: Relativt antall feil $i$ adjektivisk samsvarsbøyning etter antallet kurstimer i norsk de polskspråklige informantene har tatt før Språkprøven

\subsubsection{Oppholdstid i Norge}

Den neste faktoren med en mulig påvirkning på tilegnelse av adjektivisk samsvarsbøyning i norsk som S2 er oppholdstid i Norge. I ASK finnes det opplysninger angående oppholdstid i Norge uttrykt i følgende tidsintervaller: 0-1 år, 1-2 år, 2-3 år, 34 år, 4-5 år oppover 5 år. Tabell 12 i Metodekapittelet viser antallet informanter i hvert tidsintervall. Fordi det var få informanter som hadde bodd i Norge lenger enn 2 år, har jeg slått sammen de fire siste intervallene, og statistisksjekket følgende tre: 0-1 år, 1-2 år, over 2 år. Tabell 44 viser hvor mange feil informantene som hadde bodd i Norge $\mathrm{i}$ disse tre tidsintervallene gjorde. Den første raden viser hvor mange testtakere det er i gruppen. Summen av testtakerne utgjør ikke 200 ettersom de var 5 informanter som ikke oppga hvor lenge de hadde bodd i Norge før de tok testen. Tabellen har samme struktur som for eksempel Tabell 40, og viser gjennomsnittet av feil gjort av de polske innlærerne, medianen, standardavviket, det minste og største antallet feil gjort av minst én informant, 
antallet tekster med ingen feil og totalantallet feil. I de fleste tilfellene oppgis det både antallet forekomster av feil, og det relative antallet feil, det vil si antallet forekomster av feil i forhold til antallet kongruensforekomster. Figur 8 illustrerer de samme forholdene som Tabell 44.

\begin{tabular}{|c|c|c|c|c|c|c|}
\hline $\begin{array}{l}\text { Oppholdstid } \\
\text { i Norge }\end{array}$ & $0-1$ år & $=67$ ) & $1-2$ år ( & $=67)$ & over 2 år & $\mathrm{v}=61)$ \\
\hline & 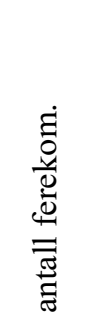 & 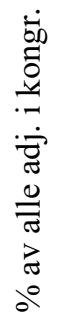 & 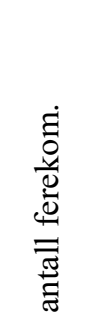 & 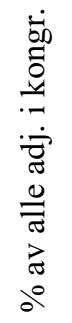 & 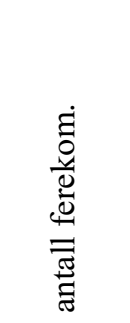 & 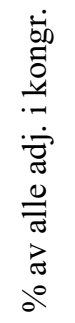 \\
\hline Gjennomsn. & 1,6 & 7,9 & 1,6 & 9 & 1,8 & 8,9 \\
\hline Median & 1 & 6,1 & 1 & 6,7 & 1 & 6,7 \\
\hline Std.avvik & 1,6 & 8,5 & 1,4 & 8,5 & 1,7 & 10,2 \\
\hline Min. & 0 & 0 & 0 & 0 & 0 & 0 \\
\hline Maks. & 7 & 43,8 & 5 & 44,4 & 6 & 55,6 \\
\hline $\begin{array}{l}\mathrm{N} \text { tekster } \\
\text { med } 0 \%\end{array}$ & 18 & & 15 & & 18 & \\
\hline TOTALT & 106 & & 110 & & 110 & \\
\hline
\end{tabular}

Tabell 44: Feil i adjektivkongruens for oppholdstid $i$ Norge 


\section{Relativt antall feil i adjektivisk samsvarsbøyning for oppholdstid i Norge}

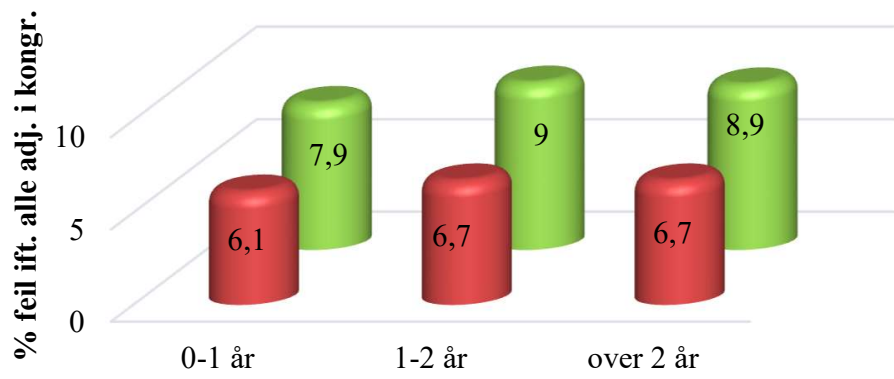

田edian $\mathbf{a j e n n o m s n i t t}$

Figur 8: Relativt antall feil $i$ adjektivisk samsvarsbøyning for oppholdstid $i$ Norge

Resultatet av Kruskal-Wallis-testen viser at forskjellene i antallet feil i adjektivkongruens hos de polske norskinnlærerne ikke påvirkes av oppholdstid i Norge siden de ikke er statistisk signifikante $\left(X^{2}=0,8788, d f=2, p>0,05\right)$.

\subsubsection{Kunnskaper i engelsk som S3}

Den siste typen faktor som blir behandlet i denne seksjonen er påvirkning av kunnskaper i engelsk som S3 på performansen i norsk samsvarsbøyning hos de polskspråklige norskinnlærerne. I ASK forekommer det 4 nivåer engelskkunnskaper: ingen kunnskaper, grunnivå (som av og til blir betegnet som begynnernivå), mellomnivå og høyere nivå. Dessuten er det noen få informanter som ikke oppga opplysninger angående sine engelskkunnskaper. Fordelingen av kunnskapsnivåene i engelsk som S3 blant de polskspråklige informantene er presentert i Tabell 45. 


\begin{tabular}{|l|c|c|c|c|}
\hline $\begin{array}{l}\text { Engelsk som } \\
\text { S3 }\end{array}$ & $\begin{array}{c}\text { ingen } \\
\text { kunnskap }\end{array}$ & grunnivå & mellomnivå & $\begin{array}{c}\text { høyere } \\
\text { nivå }\end{array}$ \\
\hline $\begin{array}{l}\text { Antall } \\
\text { informanter }\end{array}$ & 10 & 66 & 72 & 44 \\
\hline
\end{tabular}

Tabell 45: Ferdigheter i engelsk som S3 hos de polskspråklige informantene

Siden testakerne med ingen engelskkunnskaper er så få, har jeg slått denne gruppen sammen med gruppen på grunnivå. Tabell 46 viser fordelingen av feil $i$ adjektivisk kongruens gjort av de polskspråklige informantene. Den har den samme strukturen som blant annet Tabell 40, og viser antallet informanter $\mathrm{i}$ hver sammenligningsgruppe, gjennomsnittsantallet feil, medianen, standardavviket, det minste og største antallet feil gjort av minst én informant, antallet feilfrie tekster (når det gjelder samsvarsbøyning av adjektiver) og totalantallet feil. Der det er mulig, oppgir jeg to typer feil: totalantallet forekomster av feil, og det relative antallet feil som er beregnet i forhold til alle kongruensforekomstene. Figur 9 nedenfor presenterer de samme forholdene som Tabell 46. 


\begin{tabular}{|c|c|c|c|c|c|c|}
\hline $\begin{array}{l}\text { Kunnskaper } \\
\text { i engelsk } \\
\text { som S3 }\end{array}$ & \multicolumn{2}{|c|}{$\begin{array}{l}\text { grunnivå } \\
(\mathrm{N}=76)\end{array}$} & \multicolumn{2}{|c|}{$\begin{array}{l}\text { mellomnivå } \\
\qquad(\mathrm{N}=72)\end{array}$} & \multicolumn{2}{|c|}{$\begin{array}{l}\text { høyere nivå } \\
\qquad(\mathrm{N}=44)\end{array}$} \\
\hline & 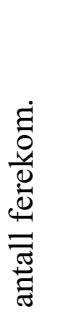 & 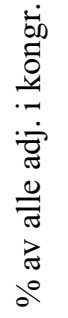 & 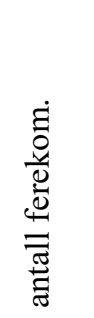 & 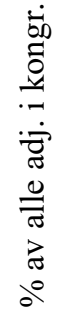 & 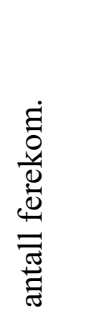 & 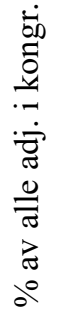 \\
\hline Gjennomsn. & 1,6 & 9,4 & 1,7 & 7,7 & 1,5 & 7,5 \\
\hline Median & 1 & 7,7 & 1 & 6,6 & 1 & 6 \\
\hline Std.avvik & 1,6 & 10,2 & 1,5 & 7,6 & 1,4 & 8 \\
\hline Min. & 0 & 0 & 0 & 0 & 0 & 0 \\
\hline Maks. & 7 & 55,6 & 6 & 44,4 & 6 & 37,5 \\
\hline $\begin{array}{l}\mathrm{N} \text { tekster } \\
\text { med } 0 \%\end{array}$ & 24 & & 17 & & 11 & \\
\hline TOTALT & 123 & & 125 & & 68 & \\
\hline
\end{tabular}

Tabell 46: Feil i adjektivkongruens etter kunnskaper i engelsk som S3 gjort av de polskspråklige informantene 


\section{Relativt antall feil i adjektivisk samsvarsbøyning etter kunnskaper i engelsk som S3}

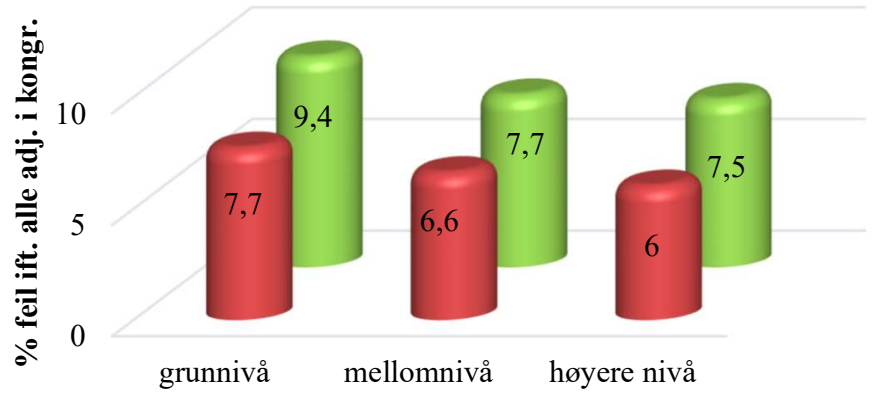

田edian घgjennomsnitt

Figur 9: Relativt antall feil i adjektivisk samsvarsbøyning etter kunnskaper $i$ engelsk som $S 3$ hos de polskspråklige informantene

Selv om en tendens til færre feil i samsvarsbøyning i norsk som S2 med økende kunnskaper i engelsk som S3 er synlig, er denne tendensen ikke statistisk signifikant, noe som Kruskal-Wallis-testen viser $\left(X^{2}=0,9881, d f=2, p>0,05\right)$. $\AA$ ha høye kunnskaper i engelsk som S3 kan altså ikke sies å være fordelaktig når det gjelder ferdigheter $\mathrm{i}$ adjektivisk samsvarsbøyning i norsk som S2.

\subsubsection{Oppsummering}

Analysen presentert ovenfor viser at to av de seks sosiale faktorene som var undersøkt har en innflytelse på de polskspråkliges performanse i norsk kongruensbøyning. Disse faktorene er: generelle norskkunnskaper og alder. Det å kunne norsk generelt bedre påvirker korrektheten i samsvarsbøyningen av de 
norske adjektivene. Når det gjelder alder, er det funnet en statistisk signifikant forskjell mellom de 30-39 år gamle og de 40-54 år gamle informantene, men ikke for eksempel mellom de 19-29 år gamle og de 40-54 år gamle informantene. Det betyr altså at korrekthet i norsk kongruensbøyning ikke øker med økende alder. Det kan finnes en annen grunn som indirekte påvirket de eldstes performansen $\mathrm{i}$ norsk kongruensbøyning. Kanskje studerte de mest, eller for eksempel var de bedre motivert til å bestå testen så godt de kunne enn de litt yngre, det vil si 30-39 år gamle.

De statistiske testene viste ingen signifikante resultater når det gjelder påvirkning av de andre faktorene på korrekthet $\mathrm{i}$ norsk samsvarsbøyning. Verken utdanning, antall kurstimer i norsk, oppholdstid i Norge eller kunnskaper i engelsk som S3 ser ut å ha noen influens på performansen i norsk kongruensbøyning. Likevel ser man en tendens at man med økende engelskkunnskapene viser større korrekthet. Denne tendensen er imidlertid ikke statistisk signifikant.

\subsection{Transferanalyse}

I transferanalysen sammenligner jeg antallet feil i adjektivkongruens gjort av de polske norskinnlærere med antallet feil i adjektivkongruens gjort av de engelsk- og tyskspråklige norskinnlærere. Grunnen til at jeg har valgt S1-engelske og tyske norskinnlærere er bredere omtalt i kapittel 2, og kort sagt ligger den $i$ at polsk, engelsk og tysk viser ulike kongruensmønstre når det gjelder adjektiver. Polsk og norsk er mest like $\mathrm{i}$ den forstand at de har kongruens i både attributiv og i predikativ stilling, engelsk er mest ulik norsk (og polsk) i at den ikke har adjektivisk samsvarsbøyning i det hele tatt, og tysk ligger i et mellomstadium ettersom den har samsvarsbøyning ved attributive adjektiver, men ikke ved predikative.

Informantene $\mathrm{i}$ alle de tre morsmålsgruppene brukte til sammen 22.968 adjektiver. Herunder falt det imidlertid alle adjektiver, også de som var blitt ekskludert i analysen, det vil 
si: ubøyelige adjektiver (f.eks. bra, annerledes), adjektiver i komparativ (f.eks. bedre, flere), adjektiver brukt som substantiver (f.eks. rødt) og adjektiver brukt adverbialt (f.eks. egentlig, spesielt). Fordelingen av bøyningstypene i hver morsmålsgruppe er presentert i Tabell 21 i Metodekapittelet (de samme forholdene som er også presentert i Figur 10 nedenfor).

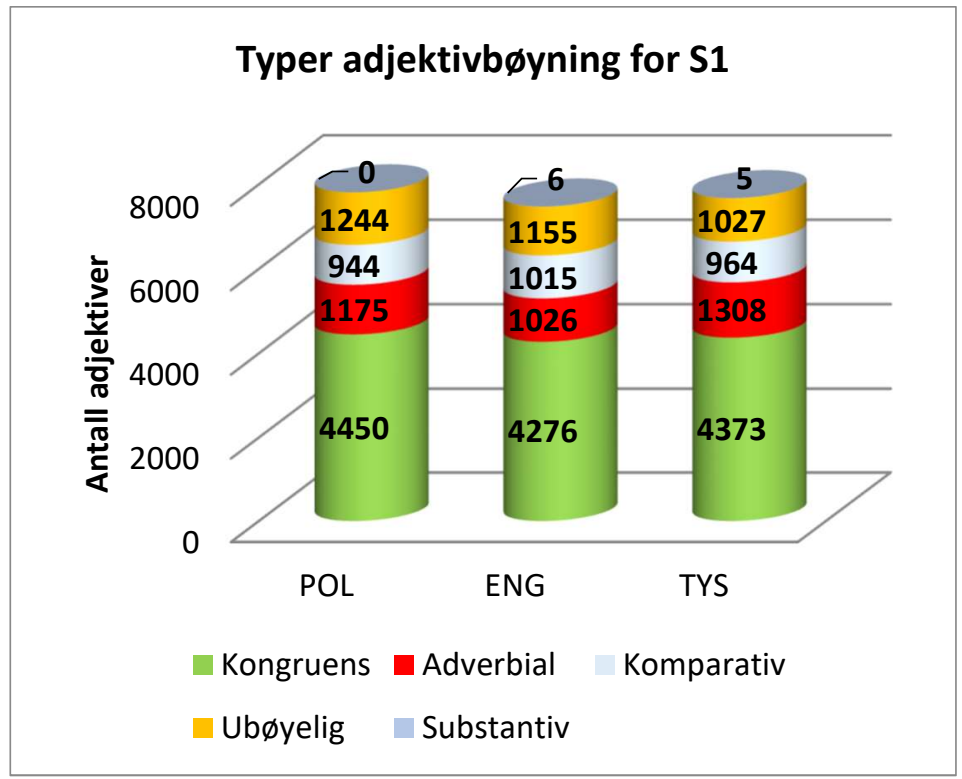

Figur 10: Typer adjektivbøyning for S1

Etter å ha ekskludert alle de ubøyelige adjektivene og adjektivformene, ble det igjen $\mathrm{i}$ analysen bare bøyelige adjektiver i positiv og superlativ som er brukt $i$ kongruens med det ordet / den frasen de modifiserer. Som allerede sagt, er forekomster av slike adjektiver referert til som forekomster av adjektivkongruens / forekomster av adjektivisk samsvarsbøyning / kongruensforekomster / alle adjektiver brukt $i$ kongruens / alle samsvarsbøyde adjektiver / alle kongruensbøyde adjektiver. Totalt var det 13.099 forekomster av adjektivkongruens i mitt datamateriale. Hver av testtakerne i 
hver av S1-gruppene bruke minst ett adjektiv i kongruens (egentlig var minimumstallet 3 oppnådd av en S1-engelsk norskinnlærer). Tabell 47 viser totalantallet adjektiver brukt i kongruens for hver av S1-gruppene. Den første raden viser størrelsen på utvalget (det var nøyaktig 200 informanter i hver av de tre S1-gruppene); den tredje raden viser gjennomsnittsverdien for antallet forekomster av adjektivisk samsvarsbøyning for én innlærer i hver morsmålsgruppe, den fjerde medianen; den femte standardavviket; den sjette - minimumsverdien (det minste antallet adjektiver oppnådd av minst én informant $\mathrm{i}$ den gitte S1-gruppen); den sjuende raden viser maksimumsverdien (det største antallet adjektiver oppnådd av minst én informant i den gitte S1-gruppen); den åttende raden viser antallet tekster der det ikke ble brukt noen adjektiver, og den nederste raden viser totalantallet adjektiver brukt av alle informantene i hver S1-gruppe. Hver gang (bortsett fra de to siste radene) er det oppgitt to tall: det absolutte antallet forekomster av adjektiver i kongruens og antallet forekomster av adjektiver $\mathrm{i}$ kongruens $\mathrm{i}$ forhold til alle ord brukt av informantene.

\begin{tabular}{|l|r|r|r|r|r|r|}
\hline S1 & \multicolumn{2}{|c|}{ POL (N=200) } & \multicolumn{2}{|c|}{ ENG (N=200) } & \multicolumn{2}{c|}{ TYS (N=200) } \\
\hline & $\begin{array}{c}\% \\
\text { antall } \\
\text { forekom. }\end{array}$ & $\begin{array}{c}\text { av } \\
\text { alle } \\
\text { ord }\end{array}$ & $\begin{array}{c}\text { antall } \\
\text { forekom. }\end{array}$ & $\begin{array}{c}\text { av } \\
\text { alle } \\
\text { ord }\end{array}$ & $\begin{array}{c}\text { antall } \\
\text { forekom. }\end{array}$ & $\begin{array}{c}\text { av } \\
\text { alle } \\
\text { ord }\end{array}$ \\
\hline Gjennomsn. & 22,3 & 5,8 & 21,4 & 5,7 & 21,9 & 5,6 \\
\hline Median & 21 & 5,8 & 20 & 5,4 & 21 & 5,3 \\
\hline Std.avvik & 9,6 & 1,6 & 9,6 & 1,8 & 10,2 & 1,7 \\
\hline Min. & 5 & 2,1 & 3 & 1,4 & 4 & 0,9 \\
\hline Maks. & 48 & 11 & 53 & 11,1 & 55 & 11,7 \\
\hline $\begin{array}{l}\text { N tekster } \\
\text { med 0\% }\end{array}$ & 0 & & 0 & & 0 & \\
\hline TOTALT & 4450 & & 4276 & & 4373 & \\
\hline
\end{tabular}

Tabell 47: Antallet forekomster av adjektivkongruens for S1 
Som man ser av Tabell 47, brukte de polskspråklige informantene gjennomsnittlig flest adjektiver i kongruens (22,3 per informant) blant alle de tre morsmålsgruppene, og de engelskspråklige brukte gjennomsnittlig færrest adjektiver (21,4 per informant). De tyskspråklige plasserer seg på annen plass (med gjennomsnittlig 21,9 adjektiver brukt av hver informant), og de viser også den største variasjonen innen gruppen (standardavvik på 10,2). Også relativt sett produserte den S1-polske gruppen flest adjektiver brukt i kongruens. Den S1-engelske gruppen er på andre plass, og den S1-tyske gruppen har skapt relativt færrest adjektiver i samsvarsbøyning. Likevel finnes det ingen signifikante forskjeller mellom de tre morsmålsgruppene når det gjelder antall forekomster av adjektivisk samsvarsbøyning produsert av informantene $\left(X^{2}=1,6013, d f=2, p>0,05\right)^{61}$. Diagram 16 presenterer disse relasjonene.

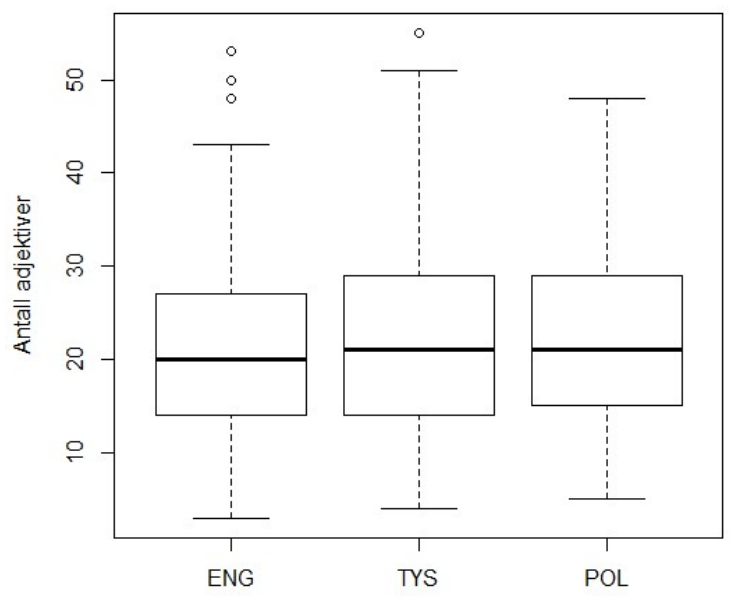

Diagram 16: Adjektiver brukt i kongruens for S1

${ }^{61}$ Kruskal-Wallis-testen. 
I Tabell 48 er det presentert antallet forekomster av feil i adjektivisk samsvarsbøyning for hver av de tre morsmålsgruppene både $\mathrm{i}$ totale $\mathrm{og}$ relative (dvs. som prosent antallet feil i adjektivkongruens utgjør i forhold til totalantallet adjektiver brukt i kongruens; dette tallet viser hvor korrekte informantene var i den adjektiviske samsvarsbøyningen) verdier. Den første raden viser størrelsen på utvalget, og den viser de samme verdiene som i Tabell 47 ettersom alle informantene brukte minst ett adjektiv i kongruens. Den tredje og fjerde raden viser respektivt gjennomsnittet og medianen av antallet feil i kongruensbøyning gjort av hver innlærer i hver av de tre S1gruppene. Den femte raden viser standardavviket, den sjette minimumsverdien (det minste antallet feil i adjektivkongruens oppnådd av minst én informant i den gitte S1-gruppen), den sjuende raden viser maksimumsverdien (det største antallet feil $i$ adjektivkongruens oppnådd av minst én informant $i$ den gitte S1-gruppen). Den nest siste raden presenterer antallet tekster som ikke inneholder noen feil i adjektivisk samsvarsbøyning. Den siste raden viser totalantallet feil gjort i adjektivkongruens i hver morsmålsgruppe. 


\begin{tabular}{|c|c|c|c|c|c|c|}
\hline S1 & \multicolumn{2}{|c|}{ POL $(\mathrm{N}=200)$} & \multicolumn{2}{|c|}{$\mathrm{ENG}(\mathrm{N}=200)$} & \multicolumn{2}{|c|}{ TYS $(\mathrm{N}=200)$} \\
\hline & 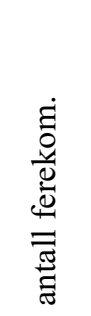 & 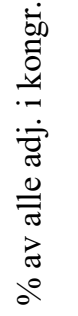 & 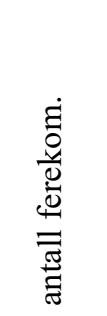 & 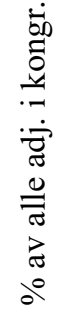 & 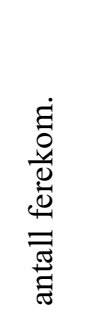 & 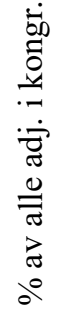 \\
\hline Gjennomsn. & 1,7 & 8,5 & 2,6 & 12,6 & 1,9 & 9,1 \\
\hline Median & 1 & 6,7 & 2 & 11,1 & 1 & 6,7 \\
\hline Std.avvik & 1,5 & 9,0 & 2,4 & 11,0 & 1,9 & 9,2 \\
\hline Min. & 0 & 0 & 0 & 0 & 0 & 0 \\
\hline Maks. & 7 & 55,6 & 13 & 57,1 & 11 & 44,4 \\
\hline $\begin{array}{l}\mathrm{N} \text { tekster } \\
\text { med } 0 \%\end{array}$ & 53 & & 36 & & 47 & \\
\hline TOTALT & 331 & & 515 & & 372 & \\
\hline
\end{tabular}

Tabell 48: Feil i adjektivkongruens for S1-gruppene

Ut av Tabell 48 kan man lese at de polskspråklige norskinnlærere gjør færrest feil (331 totalt), mens de engelskspråklige gjør flest feil (515 totalt) i samsvarsbøyning av norske adjektiver. De tyskspråklige plasserer seg i midten med totalt 372 feil. I hver av de tre morsmålsgruppene er det en del informanter som ikke gjorde noen feil i kongruensbøyning, og her er det igjen de polskspråklige som har flest (53) feilfrie (på samsvarsbøyning-området) tekster. De tyskspråklige følger etter dem (47 feilfrie tekster), og de engelskspråklige har færrest feilfrie tekster (36). De samme relasjonene er også illustrert i Diagram 17, Diagram 18 og Diagram 19. 


\section{Feil i adjektivisk samsvarsbøyning i S1 polsk}

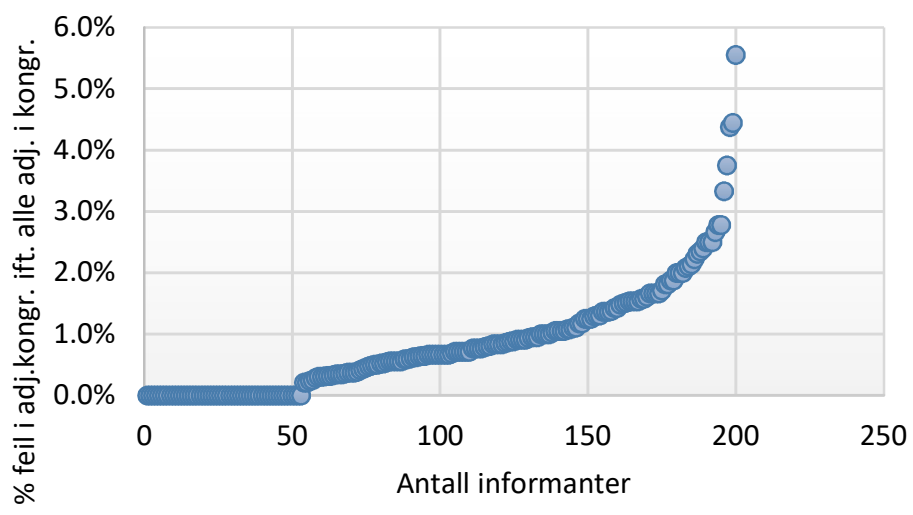

Diagram 17: Feil i adjektivisk samsvarsbøyning i S1 polsk

\section{Feil i adjektivisk samsvarsbøyning i S1 engelsk}

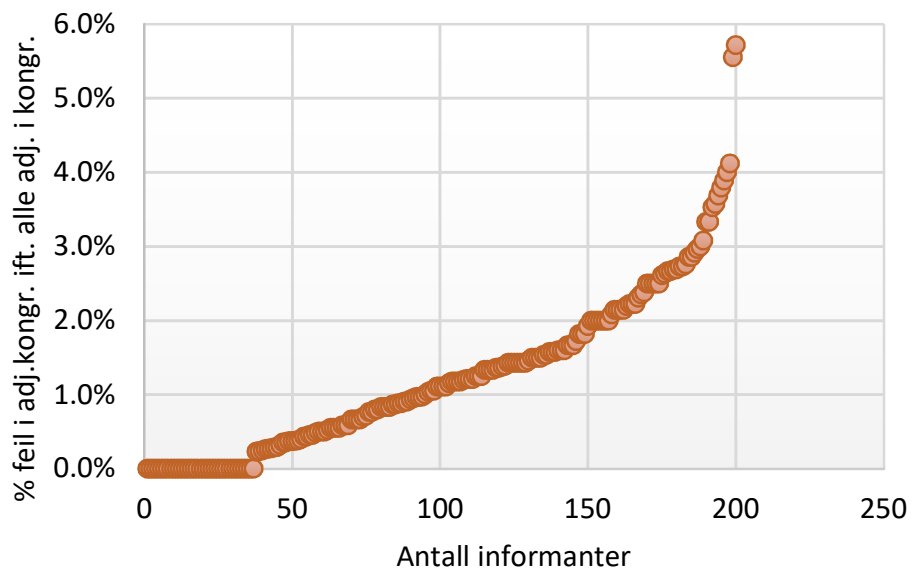

Diagram 18: Feil i adjektivisk samsvarsbøyning $i$ S1 engelsk 


\section{Feil i adjektivisk samsvarsbøyning i S1 tysk}

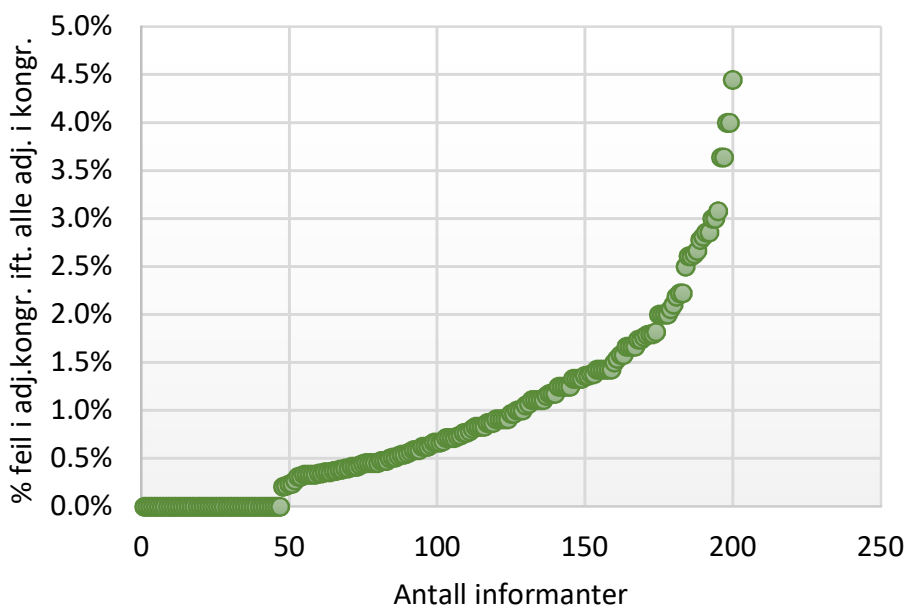

Diagram 19: Feil i adjektivisk samsvarsbøyning i S1 tysk

Transferanalysen bygger på metoden framstilt i Jarvis og Pavlenko (2008), og Jarvis (2010). Den krever å gjennomføre fire typer observasjoner for å påvise tverrspråklig innflytelse. Analysen er stort sett kvantitativ (i tilfellet intragruppehomogenitet, intergruppe-heterogenitet, og delvis innenspråklige ulikheter), men dataene er også undersøkt kvalitativt (i tilfellet tverrspråklig performansesamsvar og delvis innenspråklige ulikheter). Nedenfor er hver type observasjoner omtalt $i$ en separat seksjon, bortsett fra intragruppehomogenitet, intergruppe-heterogenitet som er omtalt sammen på grunn av at de undersøkes samtidig ved hjelp av de samme statistiske testene. 


\subsubsection{Intragruppe-homogenitet og intergruppe-heterogenitet}

Intragruppe-homogenitet og intergruppe-heterogenitet er sterkt knyttet til hverandre, og de statistiske testene (The Kruskal-Wallis analysis of ranks og the Mann-Whitney U-test) jeg bruker til å påvise deres tilstedeværelse, undersøker dem samtidig ved å sjekke om variasjon mellom gruppene er større enn variasjon innen gruppene.

Ved hjelp av Kruskal-Wallis-testen har jeg sammenlignet det relative antallet feil (dvs. antallet feil i adjektivisk samsvarsbøyning i forhold til alle adjektivene brukt i samsvarsbøyning) $i$ adjektivisk samsvarsbøyning produsert av testtakerne i alle de tre S1-gruppene: den polske, engelske og tyske (jf. Tabell 48 ovenfor og Figur 11 nedenfor). Resultatet oppnådd i denne testen viser at det forekommer signifikante forskjeller blant disse morsmålsgruppene $\left(X^{2}=18,5392, d f=2, p<0,001 * * *\right)$. Kruskal-Wallis-testen viser imidlertid ikke hvor nøyaktig den signifikante forskjellen (de signifikante forskjellene - dersom de er flere) befinner seg. Av den grunn var det nødvendig å gjennomføre en post-hoc test, Mann-Whitney-testen i dette tilfellet. Denne testen ble brukt tre ganger - for hvert S1-par separat. På grunn av gjentatte sammenligninger måtte Bonferroni-korrigering anvendes. Mann-Whitney-testen viste at signifikante forskjeller fant sted mellom to S1-par. Informantene fra den engelske S1-gruppen produserte signifikant flere feil enn informantene i de to resterende S1gruppene (ENG-TYS: $W=23863,5, p<0,01 * *$, ENG-POL: $W=$ 24616,5, $p<0,001^{* * *}$, Bonferroni-korrigering). Det ble ikke funnent noen signifikant forskjell mellom antallet feil produsert av informantene i den polske og tyske S1-gruppen (POL-TYS: $W=20682,5, \mathrm{p}>0,05$, Bonferroni-korrigering). 


\section{Relativt antall feil i adjektivisk samsvarsbøyning for S1}

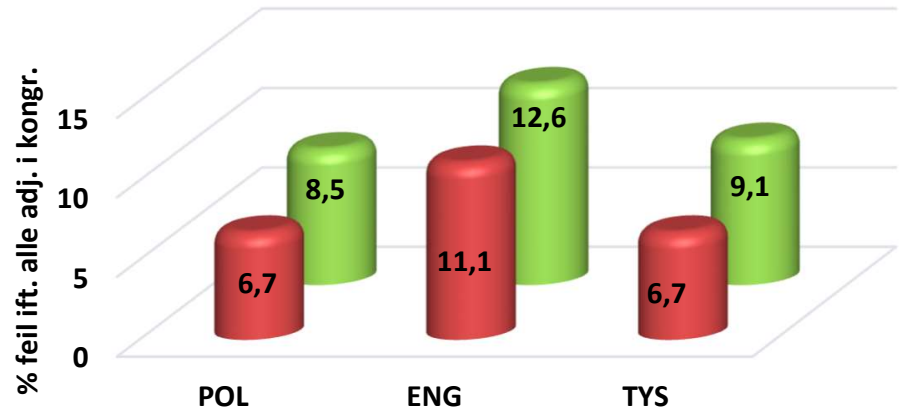

Median $\square$ Gjennomsnitt

Figur 11: Relativt antall feil i adjektivisk samsvarsbøyning for S1

\subsubsection{Tverrspråklig performansesamsvar}

I tverrspråklig performansesamsvar ser jeg på bruken av kongruensendelsene i norsk som S2 i mellomspråkene til de polsk-, engelsk- og tyskspråklige innlærerne. Ideelt sett ville man sammenligne performansen av de samme informantene $\mathrm{i}$ deres morsmål og målspråk, men med de dataene jeg står til rådighet med, er det umulig. Derfor sammenligner jeg informantenes utsagn i S2 norsk med deres potensielle utsagn i deres morsmål ${ }^{62}$. Slike potensielle utsagn har jeg laget selv ved

${ }^{62}$ Dette er gjort i samsvar med det Jarvis og Pavlenko selv påstår i beskrivelsen av metodologisk rigorisme:

Furthermore, regarding crosslinguistic performance congruity, although several studies have compared source- and recipient-language performance directly (...), a great number of studies have not done so, but instead have compared recipient-language performance with intuitions or general 
å oversette informantenes utsagn i norsk til deres morsmål (dvs. polsk, engelsk og tysk) basert på deskriptive grammatikker om disse språkene. Oversettelsene til engelsk og tysk har jeg dessuten konsultert med morsmålsbrukere av disse språkene.

Testtakernes utsagn er presentert $\mathrm{i}$ tre grupper her (hver av gruppene danner en separat underseksjon) for at presentasjonen blir mer oversiktlig. Disse gruppene er: 1) mangel på kongruens (dvs. bruk av ingen endelse når en endelse, enten - $t$ eller $-e$, er nødvendig), 2) feil bruk av kongruens (dvs. bruk av en endelse, enten - $t$ eller $-e$, når ingen endelse er nødvendig), 3) feil kongruensendelse (dvs. enten bruk av -t-endelsen når $-e$ endelsen er nødvendig eller omvendt). Tabell 49 viser fordelingen av feiltypene.

\begin{tabular}{|c|c|c|c|c|c|c|}
\hline S1 & \multicolumn{2}{|c|}{ POL } & \multicolumn{2}{|c|}{ ENG } & \multicolumn{2}{|c|}{ TYS } \\
\hline & 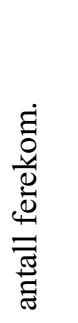 & 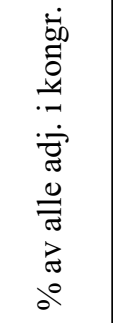 & 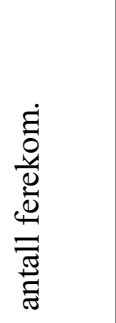 & 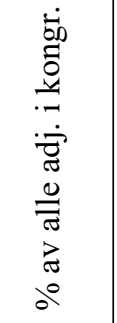 & 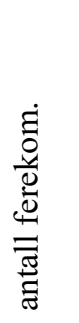 & 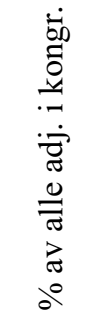 \\
\hline $\begin{array}{l}\text { mangel på } \\
\text { kongruens }\end{array}$ & 201 & $60,7 \%$ & 325 & $63,3 \%$ & 257 & $69,2 \%$ \\
\hline $\begin{array}{l}\text { feil bruk av } \\
\text { kongruens }\end{array}$ & 119 & $36,0 \%$ & 144 & $27,5 \%$ & 86 & $22,9 \%$ \\
\hline $\begin{array}{l}\text { feil } \\
\text { kongruens- } \\
\text { endelse }\end{array}$ & 11 & $3,3 \%$ & 46 & $9,2 \%$ & 29 & $7,9 \%$ \\
\hline TOTALT & 331 & & 515 & & 372 & \\
\hline
\end{tabular}

Tabell 49: Feiltyper i kongruens for S1

descriptions (e.g. written grammar) of how the source language works (...). (Jarvis \& Pavlenko 2008: 48-49) 
Ettersom antallet feil i kongruens gjort av alle testtakerne til sammen er ganske stort (det er til sammen 1218 feil i kongruens), skal jeg i denne seksjonen vise bare 10 feil av hver type i hver S1-gruppe. Hver gang skal jeg vise fem feil i attributiv stilling og fem i predikativ stilling. For å spare plass $\mathrm{i}$ kapittelet vil jeg oftest ikke angi hele setninger, men fraser i den grad det er tilstrekkelig (slik som det er gjort i det første underkapittelet).

\subsubsection{Mangel på kongruens}

\subsection{S1 polsk}

s0916 $^{63}$ : Lærer presenterer for barn kort filmer om fugler, blomster ...

Nauczyciel prezentuje dzieciom krótkie filmy o ptakach, kwiatkach ...

*kort $>$ korte

s0756: Jeg håper at norsk kongen og polsk ...

Mam nadzieję, że norweski król i polski ...

*norsk $>$ (den) norske

s0165: Det var intensiv kurs.

To był intensywny kurs.

*intensiv $>$ (et) intensivt

h0104: Menn er uten følelser og tar alt med "kald hode".

Mężczyźni są bez uczyć i biorą wszystko z ,zimną głową".

*kald $>$ kaldt

h0648: ... å se på den vakker naturen.

Patrzeć na piękną przyrodę.

*vakker > vakre

s0762: Alle var redd.

Wszyscy byli przestraszeni.

*redd $>$ redde

s0939: Enkeltepersoner kan bli mer fornuftig med å bruke bil, ... Jednostki mogą być bardziej rozsądne przy używaniu samochodu, ... $*_{\text {fornuftig }>\text { fornuftige }}$

63 Eksemplene er presentert på samme måte som i det første underkapittelet med det unntaket at feilene og korrigeringene befinner seg under informantenes ytringer og oversettelsene. 
h0454: Med stress, vår daglig venn, ...

Ze stresem, naszym codziennym przyjacielem ...

$*$ daglig $>$ daglige

s0921: Det er veldig klar at de som kommer hjem fra jobben ...

To było bardzo oczywiste, że ci, którzy przychodzą do domu z pracy ...

*klar $>$ klart

h0071: A leie leilihet er dyr men å leie hus er ...

Wynajmowanie mieszkania jest drogie, ale wynajmowanie domu jest ...

$*$ dyr $>$ dyrt

I alle tilfellene ovenfor overså de polskspråklige informantene kontekster for kongruensbøyning av norske adjektiver. Feilene informantene gjorde, er ikke i samsvar med reglene for kongruensbøyning av adjektiver i polsk der det også, slik som i norsk, kreves adjektivisk samsvarsbøyning i alle disse kontekstene.

\subsection{S1 engelsk}

s0319: Natur, musikk, hyggelig mennesker og restauranter ...

Nature, music, nice people and restaurants ...

*hyggelig > hyggelige

s0228: Alle har på seg fine klærne med norsk flag ...

Everybody is wearing fine clothes with Norwegian flags ...

*norsk $>$ (det) norske

h0498: Ingen dårlig vær, bare dårlig klær, sier jeg ...

No bad weather, only wrong clothes, I say ...

*dårlig > dårlige

s0304: Et veldig popular tema, spesielt i Norge, er været!

A very popular topic, especially in Norway, is the weather!

*popular > populært

h0271: Over hele verden er forurensing et stor problem ...

In the whole world, pollution is a big problem ...

*stor > stort

s0186: Noe andre ting som er viktig for meg ...

Some other things that are important to me ...

*viktig > viktige 
h0441: Alle mennesker skal ikke være veldig tynn, men de skal være i god helse ...

Not all people should be very thin, but they should be in good health ...

*tynn $>$ tynne

h0621: De fleste immigranter er ung og har ...

Most immigrants are young and have ...

*ung $>$ unge

s0292: Meneske som liker å bo et sted som er skitten, gatene burde være ...

People who like to live somewhere where it is dirty, streets should be ...

*skitten > skittent

h0300: Hans kjøleskap er hvit.

His fridge is white.

*hvit > hvitt

I eksemplene ovenfor oppførte de engelskspråklige norskinnlærerne seg i norsk samsvarsbøyning på samme måte som de ville oppført seg i sitt morsmål, det vil si at de ikke bøyde adjektiver i kongruens. Eller å si det på en annen måte de overså kontekster for adjektivisk kongruensbøyning i norsk.

\subsection{S1 tysk}

s0465: Jeg liker også mitt personlig livet.

Ich mag auch mein persönliches Leben.

*personlig > personlige

s0929: Jeg har sett bilfri boligområder flere ganger ...

Ich habe autofreie Wohngebiete mehrmals gesehen ...

*bilfri > bilfrie

h0557: ... når man ikke kjenner bakgrunnen til denne særegen humor.

... wenn man nicht den Hintergrund dieses eigenartigen Humors kennt.

*særegen > særegne

s0124: Hennes hus er fyllt med gamle møbler og gammel utstyr. Ihr Haus ist mit alten Möbeln und alten Geräten gefüllt. *gammel > gammelt 
h0478: Dermed har folk ofte ikke lengre hard kroppsarbeid ... Damit haben die Menschen oft keine harte körperliche Arbeit mehr ... *hard $>$ hardt

s0437: Nordmenn er fri i naturen ...

Norweger sind frei in der Natur ...

$*$ fri $>$ frie

s0965: Ikke mange er så heldig som vi.

Nicht viele sind so glücklich wie wir.

*heldig $>$ heldige

h0219: For kvinner som ikke har vært aktiv i yrkeslivet i flere år ...

Für Frauen, die seit vielen Jahren nicht beruflich aktiv sind ...

*aktiv $>$ aktive

s0935: Konseptet gjør programmet både underholdsom, lett å følge og lærrik ...

Das Konzept macht das Programm sowohl unterhaltsam, einfach zu folgen und informativ ...

*underholsom $>$ underholdsomt (egentlig: underholdene)

*lærrik > lærerikt

h0363: Et land som er rik kan ...

Ein Land, das reich ist, kann ...

*rik > rikt

Også de tyskspråklige informantene overså kontekster for adjektivisk kongruensbøyning i norsk. En del av feilene er i samsvar med korrektbruk av testakernes morsmål (når adjektivene står predikativt), men en del feil gjenspeiler ikke mønstret for adjektivsamsvarsbøyning i tysk. Informantene feilet altså i å identifisere kontekster for kongruensbøyning i norsk. 


\subsubsection{Feil bruk av kongruens}

\subsection{S1 polsk}

s0079: ... å gi barna en riktige rettning til å ...

... dać dzieciom właściwy kierunek do ...

*riktige $>$ riktig

s0761: Jeg vokste opp i en katoliske familie i ...

Dorastałam w katolickiej rodzinie w ...

*katoliske $>$ katolsk

h0196: Tiden som vi lever i nå preges av nye teknologi, ...

Czas, w którym teraz żyjemy, cechuje nowa technologia, ...

*nye > ny

s0080: Slik skaper man en trygt situasjon for barna ...

W ten sposób stwarza się bezpieczna sytuację dla dzieci ...

*trygt $>$ trygg

h0531: Så lenge man bruker sunt fornuft vil det gå riktig vei.

Jak długo używa się zdrowego rozsądku, będzie szło dobrze.

*sunt $>$ sunn

s0786: Jeg syns at mobiltelefonen er veldig viktige i ...

Uważam, że telefon komórkowy jest bardzo ważny w ...

*viktige $>$ viktig

s0761: Man kan ikke føle seg ensomme.

Nie można czuć się samotnym.

*ensomme $>$ ensom

h0474: Den tredje viktige grunnen til å være tykke er selvfølgelig...

Trzecim ważnym powodem bycia grubym jest oczywiście ...

*tykke $>$ tykk

s0943: Den er både morsomt, fullt av spenning og veldig lærerikt.

Jest zarówno zabawny, pełny napięcia i pouczający.

*morsomt $>$ morsom

$*$ fullt $>$ full

*lærerikt $>$ lærerik

h0239: Jeg tror at situasjonen i Norge er nesten optimalt ...

Uważam, że sytuacja w Norwegii jest prawie optymalna ...

*optimalt >optimal 
I tilfellene ovenfor bøyde de polskspråklige norskinnlærere adjektiver i kongruens selv om ingen bøyning var her nødvendig, og adjektivene kunne brukes i basisform. Man kan altså si at informantene markerte kontekster for adjektivisk samsvarsbøyning i samsvar med reglene som finnes i polsk, men som ikke finnes i norsk. Slik sett er tverrspråklig innflytelse en mulig forklaring for feilene.

\subsection{S1 engelsk}

S0320: ... er en del av et trivilige sted.

$\ldots$ is a part of a pleasant place.

*trivilige $>$ trivelig

s0319: Gode musikk, venner og mat er nesten alt man trenger.

Good music, friends and food is almost everything one needs.

*gode $>$ god

h0456: ... er det viktigste å lære folk i unge alder.

... is the most important (thing) to teach people at a young age.

*unge $>$ ung

s0319: ... er ikke så morsomt med is, snø og ... kaldt vind.

$\ldots$ is not so funny with ice, snow and ... cold wind.

*kaldt $>$ kald

h0423: ... problemet ved å spise sunnt mat.

... the problem with eating healthy food.

*sunnt $>$ sunn

s0338: Kanskje jeg er bare litt for gamle for å ...

Maybe I am just a bit too old to ...

$*_{\text {gamle }}>$ gammel

h0179: Jeg er ikke negative til " importering " av helsepersonell fra andre land ...

I am not negative to "importing" (against importing) the health personnel from other countries ...

*negative $>$ negativ

s0301: Jeg er sikkert på at det er noe som jeg ...

I am sure that this is something which I ...

*sikkert > sikker

h0614: ... lønn er ikke så lavt ...

... salary is not so low ...

*lavt > lav 
h0472: ... og er derfor nødt til å spise mat som er enkelt å forberede.

$\ldots$ and are therefore forced to eat food that is easy to prepare.

*enkelt $>$ enkel

Feilene vist ovenfor, som de engelskspråklige informantene gjorde, er ikke i samsvar med korrekt bruk av engelske adjektiver der de aldri blir bøyd. Tekstakerne feilte altså i å identifisere kontekster for adjektivisk kongruensbøyning i norsk slik at de betraktet ikke-kontekster som kontekster, og følgelig bøyde adjektivene til tross for at dette var i strid både med norsk og deres morsmål, det vil si engelsk.

\subsection{S1 tysk}

s0462: ... forandre seg ofte til en vanlige ting.

... ändern sich oft in eine gewöhnliche Sache.

*vanlige > vanlig

s0463: De sammenlignete med norske mat.

Sie verglichen (es) mit norwegischem Essen.

*norske $>$ norsk

h0578: Denne er en gjensidige prossess.

$\mathrm{Er}$ ist ein gegenseitiger Prozess.

*gjensidige $>$ gjensidig

s0460: Det var bare en liten fortelling, fra en normalt dag i en normalt by.

Das war nur eine kleine Geschichte von einem normalen Tag in einer normalen Stadt.

$*_{\text {normalt }>\text { normal }}$

*normalt $>$ normal

h0557: ... og så har vi en godt tysk humor.

... und so haben wir einen guten deutschen Humor.

* godt $>$ god

h0482: ... tilgangen til idrettslagene må være lette.

... der Zugang zu den Sportvereinen muss einfach sein.

*lette $>$ lett

s0910: Men luft er likevel så rent her i Oslo ...

Aber die Luft ist immer noch so sauber hier in Oslo ...

*rent $>$ ren 
s0457: Kanskje jeg er veldig negativt men også positivt.

Vielleicht bin ich sehr negativ aber auch positiv.

*negativt $>$ negativ

*positivt $>$ positiv

h0588: Faren er stort at innvandrerne ...

Die Gefahr ist groß, dass Einwanderer ...

*stort > stor

h0395: Hvis man er godt vil man være enda bedre.

Wenn man gut ist, will man noch besser sein.

*godt $>$ god

Feil bruk av kongruens hos de tyskspråklige er delvis i samsvar med korrekt bruk av informantenes morsmål, og delvis ikke. I attributiv stilling kongruensbøyde innlærerne adjektiver slik som de ville gjort i tysk, men det samme gjorde de også i predikativ stilling der det i tilfellene ovenfor behøvdes kongruens verken i norsk eller i tysk. Man kan altså si at de tyske informantene feilte i å identifisere kongruenskontekster i norsk.

\subsubsection{Feil kongruensendelse}

\subsection{S1 polsk}

s0794: Det er ikke pengene, pent huset ...

To nie pieniądze, ładny dom ...

*pent > (det) pene

s0726: ... slik at noen falskt ord kan skade ...

... tak że kilka fałszywych słów może skrzywdzić ...

$*_{\text {falskt }>\text { falske }}$

h0081: Stadig flere er fascinert over "det godt livet" ...

Coraz więcej jest zafascynowanych "dobrym życiem" ...

*godt $>$ gode

h0026: Så hvorfor tjener lærere så lite for deres hardt arbeid?

Więc dlaczego nauczyciele zarabiają tak mało za swoją ciężka pracę?

*hardt $>$ harde 
s0791: ... internett som skal være mest populært middel til å komunisere ...

... internet, który będzie najbardziej popularnym środkiem komunikacji ...

*(mest) populært > (det mest) populære

s0770: Livet er så enkle.

Życie jest takie łatwe.

*enkle > enkelt

s0734: De føler seg dumt.

Czują się głupi / głupio.

*dumt $>$ dumme

s0078: Barn må føle seg trygt ...

Dzieci muszą czuć się bezpieczne / bezpiecznie...

*trygt $>$ trygge

h0454: Det fører til en situasjon hvor vi vil se godt ut ...

To prowadzi do sytuacji, gdzie chcemy dobrze wyglądać ...

*godt $>$ gode

h0641: ... kan vi ... føle oss ensomt.

... możemy ... czuć się samotni.

*ensomt $>$ ensomme

Eksemplene ovenfor viser at de polskspråklige norskinnlærerne noen ganger klarte å identifisere kontekst for kongruensbøyning i norsk, men brukte en feil endelse da. De gjorde likevel få slike feil (11 til sammen), og feilene berører vanligvis enten adjektivbøyning i definitte fraser, genitivfraser, eller uttrykkene å føle seg, å se ut hvor det i norsk er samsvarsbøyning av adjektiver, og i polsk - adverbialbøyning.

\subsection{S1 engelsk}

s0303: Tradisjoner er også en gode møte for man å lære ...

Traditions are also a good way for one to learn ...

*gode $>$ god

h0621: ... og har en lenge arbeidsliv for seg.

... and have a long working life ahead of him.

$*$ (en) lenge $>$ (et) langt 
h0622: ... medfører til en stabile ansettelseforhold for lærere.

... leads to a stable employment for teachers.

*(en) stabile $>$ (et) stabilt

s0321: ... at man føler seg behagelig i det nytt land.

... that one feels comfortable in the new country.

*nytt > nye

h0255: Kanskje det er resultat av det tradisjonelt bilde av menn ...

Maybe this is the result of the traditional image of men ...

*tradisjonelt $>$ tradisjonelle

s0292: Et trivelig bosted bør også være flerkulturelle.

A pleasant place to live should also be multicultural.

$*_{\text {flerkulturelle }>\text { flerkulturelt }}$

s0294: Dessuten var det meget skitne der ...

Furthermore, it was very dirty there ...

*skitne $>$ skittent

h0289: ... er Amerika nok litt mer tradisjonelle ...

... America is probably a bit more traditional ...

*tradisjonelle $>$ tradisjonell

s0350: Forståelse for at ikke alle mennesker er likt er også noe som jeg synes er viktig.

Understanding that not all people are equal is also something which I think is important.

*likt $>$ like

h0271: ... i de største byene hvor gatene er fult av trafikk hele dagen rundt.

... in the largest cities where streets are full of traffic the whole day long.

$*$ fult $>$ fulle

Også de engelskspråklige informantene klarte noen ganger å identifisere kontekster for adjektivisk samsvarsbøyning korrekt, men de feilet i å velge den riktige bøyningsendelsen. Slike feil er imidlertid relativt sjeldne i denne S1-gruppen - de utgjør kun 9,2\% av alle feil gjort i kongruensbøyning. 


\subsection{S1 tysk}

s0455: Da får man også litt sosiale samfunn.

Dann bekommt man auch eine wenig soziale Gesellschaft.

*sosiale > sosialt

s0460: Gammelt folg sa at det er bedre å snakke ...

Alte Menschen haben gesagt, dass es besser ist zu sagen ...

*gammelt $>$ gamle

s0443: Verdtfulle er de lite momenter i livet ...

Wertvoll sind die kleinen Momente im Leben ...

*lite > små

h0211: ... de trives så veldig godt i sitt nesten bilfritt bysentrum.

... sie gedeihen so sehr gut in ihrem fast autofreien Stadtzentrum.

*bilfritt $>$ bilfrie

h0316: Men tross alt det negativet, er jeg ...

Aber trotz allem negativen bin ich ...

*negativet $>$ negative

s0989: ... og jeg tror det er veldig likke som Norge.

... und ich denke, dass das sehr ähnlich wie in Norwegen ist.

*likke $>$ likt

s0433: Nordmenn er veldig glade i sport, særlig å gå på ski og å spille fotball er svært populære.

Norweger mögen Sport sehr, besonders Skifahren und Fußball spielen ist sehr populär.

*populære > populært

h0321: ... og dens forskjellige tjenester er særlig populært blant unge kvinner.

... und seine verschiedenen Dienstleistungen sind besonders populär bei jungen Frauen.

*populært > populære

h0575: De er nytt i et land.

Sie sind neu im Land.

*nytt > nye

s0998: Boligprisene er alt for høyt i sveits.

Die Hauspreise sind viel zu hoch in der Schweiz.

*høyt > høye 
De tyskspråklige norskinnlærerne, slik som de polsk- og engelskspråklige, gjorde noen ganger feil i å velge bøyningsendelse ved adjektivet, men ellers identifiserte de tilstedeværelsen av kongruenskontekst korrekt. I tilfellet attributiv stilling var det samsvar mellom norsk og tysk i tilværelse av kongruensbøyningskontekst, men i tilfellet predikativ stilling fantes en slik kontekst bare i norsk.

\subsubsection{Innenspråklige ulikheter}

Innenspråklige ulikheter er en type observasjoner hvor man sammenligner to eller flere trekk som er ulikt distribuert i kildeog målspråket. I tilfellet adjektivisk samsvarsbøyning er kongruensdistribusjon mellom attributter og predikativer en god illustrasjon til dette fenomenet. Her vil hovedfokuset ligge på de tyskspråklige informantene ettersom det nettopp er tysk som skiller mellom attributiv (tilstedeværelse av samsvarsbøyning) og predikativ (fravær av samsvarsbøyning) stilling når det gjelder adjektivkongruens.

Tabell 50 og Tabell 51 viser distribusjonen av alle adjektiver brukt i attributiv (Tabell 50) og predikativ (Tabell 51) stilling. Øverste rad viser antallet informanter som har brukt adjektiver i henholdsvis attributiv og predikativ posisjon. Den tredje raden viser gjennomsnittsverdiene for hver testtager, den fjerde - medianen, den femte - standardavviket, den sjette - minimumsverdien (det minste antallet adjektiver brukt i attributiv / predikativ posisjon av minst én informant), den sjuende - maksimumsverdien (det største antallet adjektiver brukt i attributiv / predikativ posisjon av minst én informant), den nest siste raden viser antallet tekster hvor det ikke ble brukt noen adjektiver i attributiv / predikativ posisjon, og den nederste raden viser totalantallet adjektiver i attributiv / predikativ posisjon brukt av alle informantene i den gitte S1-gruppen. Bortsett fra de to siste radene er det oppgitt to tall til hver statistikk: antallet forekomster som viser til det reelle tallet adjektiver brukt av informantene, og prosent av alle adjektiver brukt i kongruens 
(dvs. antallet adjektiver brukt $\mathrm{i}$ henholdsvis attributiv og predikativ stilling delt på antallet alle adjektiver brukt i kongruens).

\begin{tabular}{|c|c|c|c|c|c|c|}
\hline \multirow[t]{2}{*}{ S1 } & \multicolumn{2}{|c|}{ POL $(\mathrm{N}=200)$} & \multicolumn{2}{|c|}{$\mathrm{ENG}(\mathrm{N}=198)$} & \multicolumn{2}{|c|}{ TYS (N=199) } \\
\hline & 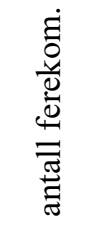 & 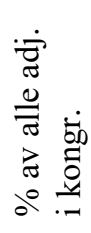 & 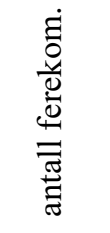 & 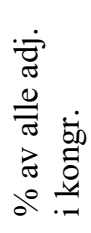 & 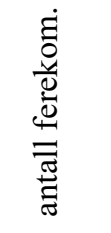 & 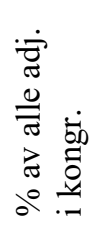 \\
\hline Gjennomsn. & 13,6 & 59,8 & 12,3 & 55,5 & 13,3 & 58,6 \\
\hline Median & 12 & 62,5 & 11 & 56,4 & 12 & 60 \\
\hline Std.avvik & 7,6 & 17,0 & 7,1 & 16,5 & 7,8 & 16,1 \\
\hline Min. & 1 & 8,3 & 0 & 0 & 0 & 0 \\
\hline Maks. & 40 & 100 & 35 & 90 & 39 & 89,3 \\
\hline $\begin{array}{l}\mathrm{N} \text { tekster } \\
\text { med } 0 \%\end{array}$ & 0 & & 2 & & 1 & \\
\hline TOTALT & 2727 & & 2460 & & 2667 & \\
\hline
\end{tabular}

Tabell 50: Adjektiver brukt i samsvarsbøyning $i$ attributiv stilling for S1

\begin{tabular}{|c|c|c|c|c|c|c|}
\hline \multirow[t]{2}{*}{ S1 } & \multicolumn{2}{|c|}{ POL (N=199) } & \multicolumn{2}{|c|}{$\mathrm{ENG}(\mathrm{N}=200)$} & \multicolumn{2}{|c|}{ TYS (N=200) } \\
\hline & 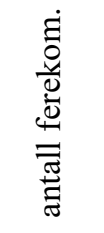 & 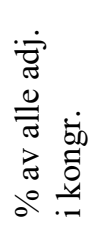 & 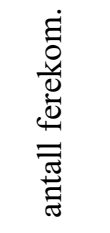 & 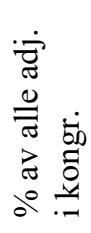 & 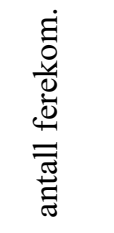 & 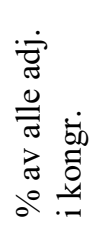 \\
\hline Gjennomsn. & 8,6 & 40,2 & 9,08 & 44,5 & 8,53 & 41,4 \\
\hline Median & 8 & 37,5 & 8,5 & 43,7 & 8 & 40 \\
\hline Std.avvik & 4,4 & 17,0 & 4,7 & 16,5 & 4,5 & 16,1 \\
\hline Min. & 0 & 0 & 1 & 10 & 1 & 10,7 \\
\hline Maks. & 23 & 91,7 & 29 & 100 & 26 & 100 \\
\hline $\begin{array}{l}\mathrm{N} \text { tekster } \\
\text { med } 0 \%\end{array}$ & 1 & & 0 & & 0 & \\
\hline TOTALT & 1723 & & 1816 & & 1706 & \\
\hline
\end{tabular}

Tabell 51: Adjektiver brukt i samsvarsbøyning i predikativ stilling for S1 
Som man ser i Tabell 50, produserte hver av de S1polskspråklige testtakerne adjektiver i attributiv stilling, mens det var 2 engelskspråklige og 1 tyskspråklig norskinnlærer som ikke produserte noen adjektiver i denne funksjonen (derfor står det at henholdsvis $\mathrm{N}=198$ og $\mathrm{N}=199$ ). Informantene med polsk som morsmål produserte også flest adjektiver i attributiv posisjon, både totalt sett (2727 forekomster) og gjennomsnittlig $(59,8 \%$ av alle adjektiver brukt i samsvarsbøyning). De engelskspråklige norskinnlærerne produserte færrest adjektiver både totalt sett (2460 forekomster) og gjennomsnittlig $(55,5 \%$ av alle adjektiver brukt i samsvarsbøyning), og de tyskspråklige norskinnlærerne plasserte seg imellom med 2667 forekomster totalt og gjennomsnittet på 58,6\% av alle adjektiver brukt i samsvarsbøyning.

Et annet bilde kommer fra Tabell 51. Når det gjelder antallet adjektiver i samsvarsbøyning i predikativ stilling, er det kun én person med polsk språkbakgrunn som ikke brukte noen adjektiver i predikativ stilling (derfor $\mathrm{N}=199$ ). Alle informantene $\mathrm{i}$ de to resterende morsmålsgruppene brukte minst ett adjektiv i predikativfunksjonen. I tilfellet adjektiver i samsvarsbøyning i predikativ stilling er de S1-egelskspråklige innlærerne på første plass med flest slike adjektiver (1816 totalt, og gjennomsnittet på $44,5 \%$ av alle bøyelige adjektiver brukt i samsvarsbøyning). De tyskspråklige informantene brukte færrest adjektiver i predikativposisjonen totalt sett (1706 forekomster), men det er de polskspråklige som gjennomsnittlig brukte færrest slike adjektiver (40,2 \% av alle bøyelige adjektiver brukt i samsvarsbøyning), mens de tyskspråklige brukte gjennomsnittlig $41,4 \%$ av alle bøyelige adjektiver i samsvarsbøyning i predikativstilling. De polskspråklige produserte totalt 1723 adjektiver i samsvarsbøyning i predikativ stilling.

Diagram 20 og Diagram 21 illustrerer forskjellene i produksjonen av adjektiver i kongruens i respektiv attributiv og predikativ posisjon. 


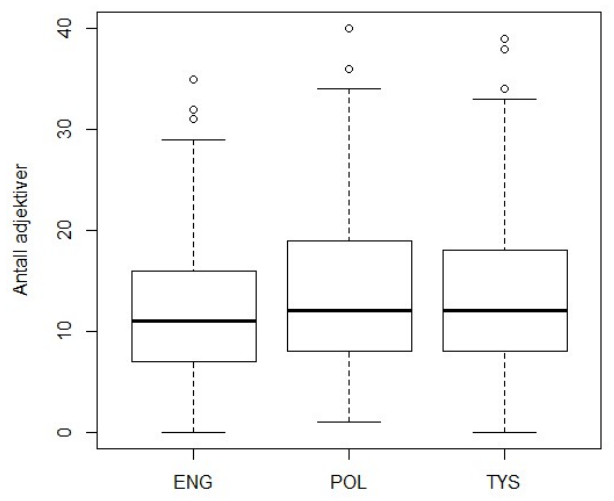

Diagram 20: Adjektiver i kongruens $i$ attributiv stilling for S1

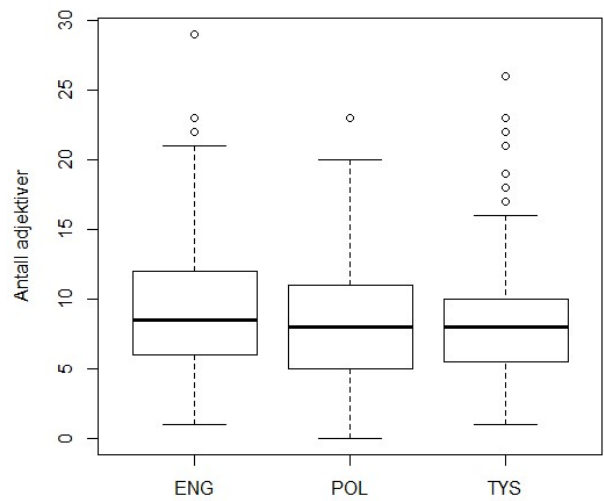

Diagram 21: Adjektiver i kongruens i predikativ stilling for S1

Jeg talte hvor mange feil informantene fra hver morsmålsgruppe gjorde $\mathrm{i}$ attributiv og predikativ stilling. Tabell $52 \mathrm{og}$ Tabell 53 nedenfor viser en oppsummering for respektivt attributter og predikativer. I tabellene viser den øverste raden 
antallet informanter som produserte adjektiver i attributiv / predikativ funksjon. Den tredje raden viser det gjennomsnittlige antallet feil i attributiv / predikativ funksjon, den fjerde raden viser medianen, den femte - standardavviket, den sjette minimumsverdien (dvs. det minste antallet feil gjort av minimum én innlærer), den sjuende maksimumsverdien (dvs. det største antallet feil gjort av minimum én innlærer), den åtte raden viser antallet tekster hvor det ikke ble gjort noen feil i adjektivkongruens i attributiv/ predikativ stilling, og den siste raden viser totalantallet feil i attributiv / predikativ posisjon gjort av alle innlærerne fra den gitte S1-gruppen.

\begin{tabular}{|c|c|c|c|c|c|c|}
\hline \multirow[t]{2}{*}{ S1 } & \multicolumn{2}{|c|}{ POL $(\mathrm{N}=200)$} & \multicolumn{2}{|c|}{ ENG $(\mathrm{N}=198)$} & \multicolumn{2}{|c|}{ TYS (N=199) } \\
\hline & 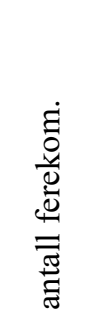 & 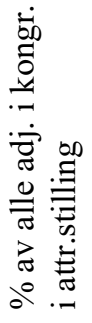 & 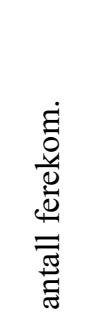 & 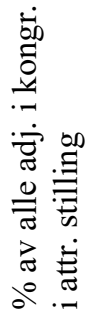 & 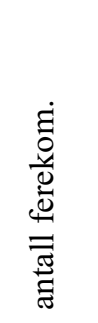 & 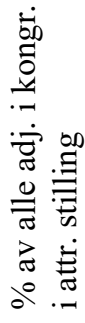 \\
\hline Gjennomsn. & 0,9 & 9,0 & 1,3 & 11,5 & 0,8 & 6,7 \\
\hline Median & 1 & 5,5 & 1 & 6,7 & 0 & 0 \\
\hline Std.avvik & 1,0 & 12,5 & 1,6 & 13,9 & 1,1 & 9,9 \\
\hline Min. & 0 & 0 & 0 & 0 & 0 & 0 \\
\hline Maks. & 6 & 100 & 12 & 66,7 & 7 & 50 \\
\hline $\begin{array}{l}\mathrm{N} \text { tekster } \\
\text { med } 0 \%\end{array}$ & 81 & & 79 & & 103 & \\
\hline TOTALT & 188 & & 260 & & 162 & \\
\hline
\end{tabular}

Tabell 52: Feil i adjektivisk samsvarsbøyning $i$ attributiv stilling for S1 


\begin{tabular}{|c|c|c|c|c|c|c|}
\hline \multirow[t]{2}{*}{ S1 } & \multicolumn{2}{|c|}{ POL $(\mathrm{N}=199)$} & \multicolumn{2}{|c|}{ ENG $(\mathrm{N}=200)$} & \multicolumn{2}{|c|}{ TYS (N=200) } \\
\hline & 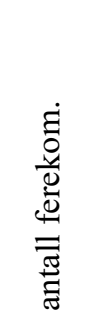 & 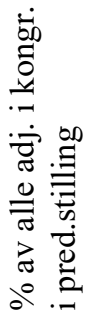 & 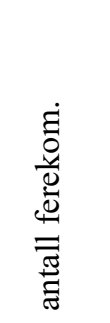 & 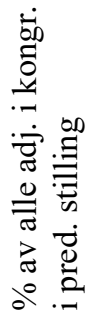 & 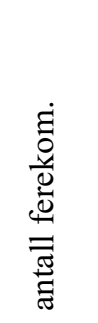 & 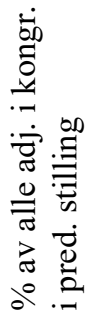 \\
\hline Gjennomsn. & 0,7 & 8,9 & 1,3 & 14,7 & 1,1 & 13,4 \\
\hline Median & 0 & 0 & 1 & 10 & 1 & 8,3 \\
\hline Std.avvik & 1,0 & 14,9 & 1,5 & 16,8 & 1,4 & 17,1 \\
\hline Min. & 0 & 0 & 0 & 0 & 0 & 0 \\
\hline Maks. & 5 & 100 & 9 & 100 & 9 & 100 \\
\hline $\begin{array}{l}\mathrm{N} \text { tekster } \\
\text { med } 0 \%\end{array}$ & 114 & & 74 & & 89 & \\
\hline TOTALT & 143 & & 255 & & 210 & \\
\hline
\end{tabular}

Tabell 53: Feil i adjektivisk samsvarsbøyning i predikativ stilling for S1

De tyskspråklige norskinnlærere gjorde færrest feil i kongruensbøyning $i$ attributiv stilling (162 feil totalt, gjennomsnittlig $6,7 \%$ av adjektivene brukt som attributter var ukorrekt), mens de engelskspråklige gjorte flest feil i denne stillingen (260 totalt, gjennomsnittlig $11,5 \%$ av adjektivene brukt som attributter var ukorrekt). De polskspråklige informantene plasserte seg i midten med 188 feil totalt (gjennomsnittlig $9 \%$ av adjektivene brukt som attributter var ukorrekt). I den tyske S1-gruppen var det også flest feilfrie tekster (når det gjelder samsvarsbøyning av adjektiver i attributiv posisjon) - 103, mens i den engelske S1-gruppen var det færrest feilfrie tekster (74). Den polske S-gruppen skiller seg fra de to resterende $i$ at det var der minst én informant som samsvarsbøyde alle adjektiver i attributiv posisjon ukorrekt, mens alle testtakerne $\mathrm{i}$ de den engelske og tyske S1-gruppen viste større korrekthetsnivå.

I predikativ stilling er det de polskspråklige innlærerne som var mest korrekte - de hadde færrest feil totalt (143) og 
gjennomsnittlig $(8,9 \%$ av adjektivene brukt som predikativer var ukorrekt). De tyskspråklige informantene plasserte seg på andre plass med 210 feil totalt (gjennomsnittlig 13,4\% av adjektivene brukt som predikativer var ukorrekt), og de engelskspråklige performerte dårligst med flest feil totalt sett 255 (gjennomsnittlig 14,7\% av adjektivene brukt som predikativer var ukorrekt) blant de tre morsmålsgruppene. De polskspråklige testtakerne hadde dessuten flest feilfrie tekster (når det gjelder samsvarsbøyning av adjektiver $\mathrm{i}$ predikativ posisjon) - 114, mens de engelskspråklige hadde minst feilfrie tekster (74), og de tyskspråklige hadde 89 feilfrie tekster. I hver av de tre morsmålsgruppene var det minst én person som samsvarsbøyde alle adjektiver i predikativ stilling ukorrekt.

Diagram 22, Diagram 23 og Diagram 24 illustrerer forholdet mellom antallet feil $i$ attributiv stilling og antallet feil i predikativ stilling for hver S1-gruppe separat. Den polske morsmålsgruppen skiller seg fra de to andre gruppene $i$ at de polskspråklige informantene gjorde færre feil i predikativ stilling en $i$ attributiv stilling, mens det var omvendt $i$ den engelske og tyske morsmålsgruppen. 


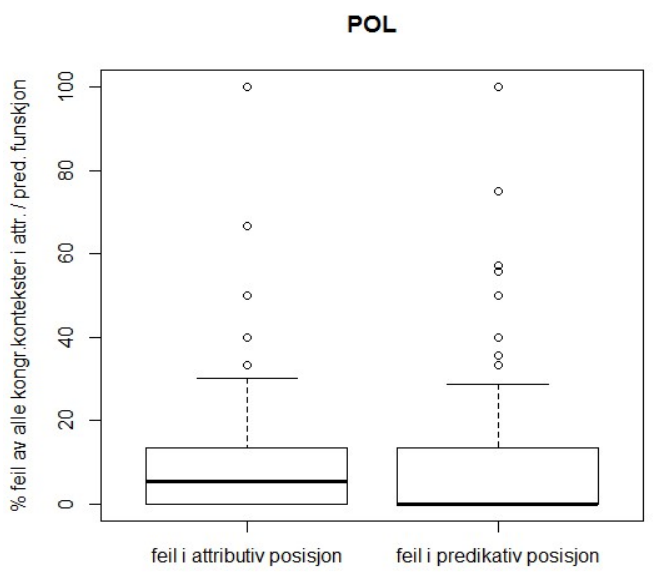

Diagram 22: De S1-polskspråkliges feil i adjektivkongruens som prosent av alle adjektiver $i$ kongruens de produserte $i$ attributiv og predikativ stilling

ENG

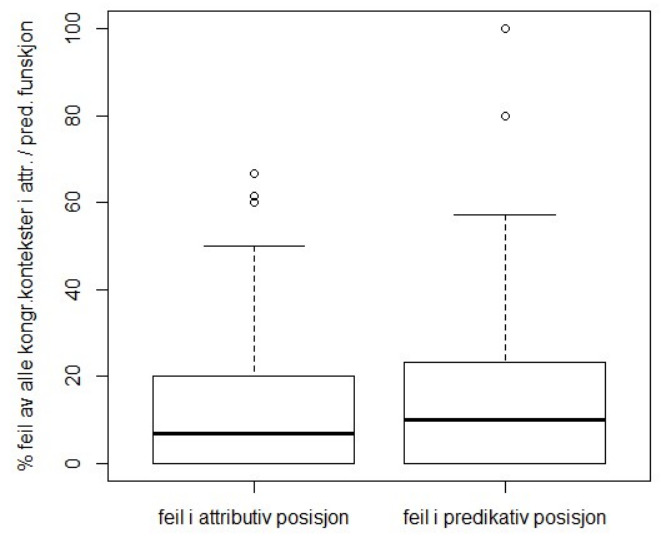

Diagram 23: De S1-engelskspråkliges feil i adjektivkongruens som prosent av alle adjektiver $i$ kongruens de produserte $i$ attributiv og predikativ stilling 


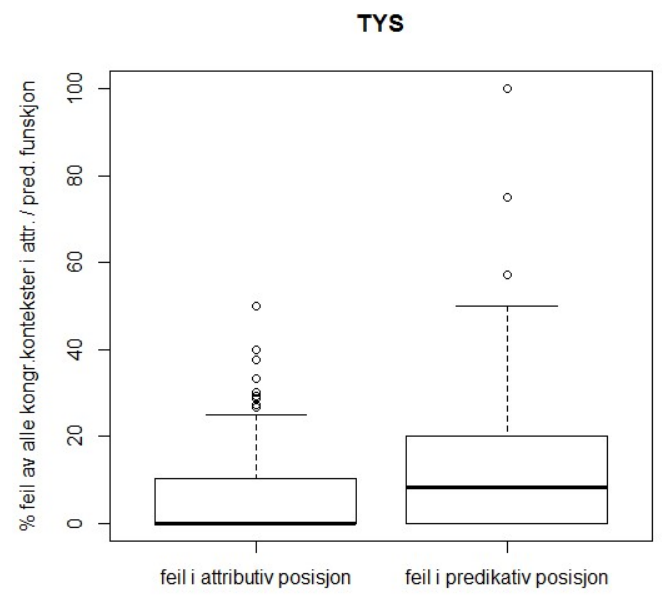

Diagram 24: De S1-tyskspråkliges feil i adjektivkongruens som prosent av alle adjektiver $i$ kongruens de produserte $i$ attributiv og predikativ stilling

I analysen av innenspråklige ulikheter brukes The Wilcoxon signed-ranks. Testen sjekker hvorvidt det var noen signifikante forskjeller mellom antallet feil i adjektivisk samsvarsbøyning $\mathrm{i}$ attributiv og predikativ stilling i hver av de analyserte S1-gruppene. Fordi den anvendes tre ganger (hver S1-gruppe testes separat), må Bonferroni-korrigering brukes. Testen viste ingen signifikante resultater i samsvarsbøyning av adjektiver i attributiv og predikativ stilling i tilfellet morsmålsbrukerne av polsk og engelsk (POL: $V=5290,5, p>0,05$, ENG: $V=5346,5, p>0,05$, Bonferroni-korrigering), men den viste en høyt signifikant forskjell hos de tyskspråklige informantene. De gjør signifikant flere feil i samsvarsbøyning av predikative adjektiver enn attributive adjektiver $(V=3233, p<0,001 * * *$, Bonferroni-korrigering).

Figur 12 og Figur 13 nedenfor illustrer de ovennevnte forholdene. 


\section{Relativt antall feil i attributiv stilling for S1}
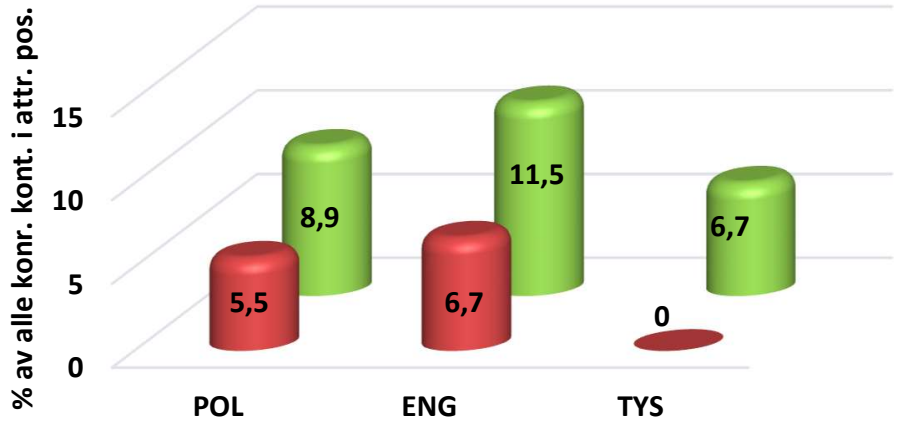

Median Gjennomsn.

Figur 12: Relativt antall feil $i$ attributiv stilling for $S 1$

\section{Relativt antall feil i predikativ stilling for S1}
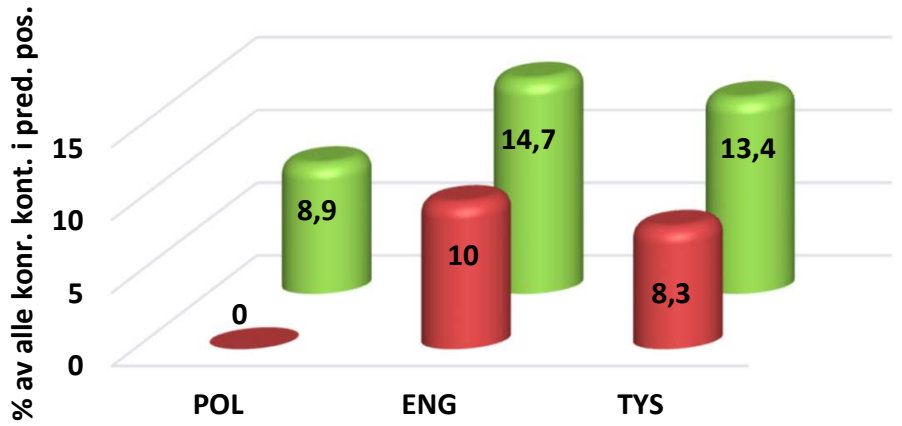

Median

Figur 13: Relativt antall feil i predikativ stilling for S1 


\subsubsection{Oppsummering}

Når det gjelder de polskspråklige informantenes performanse i norsk samsvarsbøyning av adjektiver, kan hypotesen om at transfer er en faktor som påvirker den, bekreftes. Den polskspråklige morsmålsgruppen er homogen når det gjelder antall feil den gjør i norsk kongruens (kravet om intragruppehomogenitet er oppfylt), dens performanse i norsk samsvarsbøyning er signifikant bedre enn performansen til den engelske morsmålsgruppen (kravet om intergruppe-heterogenitet er oppfylt), og gruppen oppfører seg likt (med ingen signifikante forskjeller) både i samsvarsbøyning av attributter og predikativer (kravet om innenspråklige ulikheter er oppfylt). Det forekommer imidlertid ikke fullt tverrspråklig performansesamsvar, derfor er dette kravet ikke påvist helhetlig. Likevel kan man påstå at det å ha polsk som morsmål virker fordelaktig på tilegnelsen av norsk samsvarsbøyning av adjektiver.

Resultatet som kommer fra transferanalysen er at det er påvist negativ transfer i den S1-engelske gruppen ettersom den oppfyller alle de fire kravene som er trengt til å bevise transfer, det vil si intragruppe-homogenitet, intergruppe-heterogenitet, tverrspråklig performansesamsvar (med noen unntak som likevel kan oppfattes som mislykte forsøk i tilegnelsen av den norske samsvarsbøyningen) og innenspråklige ulikheter. Denne morsmålsgruppen er altså både homogen og skiller seg ut fra de to resterende $\mathrm{S} 1$-gruppene når det gjelder performansen i norsk kongruensbøyning av adjektiver. Feilene viser stort sett samsvar med korrekt bruk av engelske adjektiver der de aldri blir bøyd, og de forekommer like ofte i attributiv og i predikativ stilling. Man kan altså konkludere med at det å ha engelsk som morsmål virker hindrende på tilegnelsen av norsk samsvarsbøyning av adjektiver (iallfall i sammenligning med det å ha polsk eller tysk som morsmål). 
Også hypotesene angående den tyske morsmålsgruppen blir bekreftet her. Gruppen er homogen (kravet om intragruppehomogenitet er oppfylt), er oftere korrekt i norsk samsvarsbøyning enn den engelske S1-gruppen (kravet om intergruppeheterogenitet er oppfylt), og oppfører seg signifikant mindre korrekt i predikativ stilling enn i attributiv stilling (kravet om innenspråklige ulikheter er oppfylt), noe som kan flere ganger sees når man sammenligner gruppens performanse i norsk og tysk. Likevel finnes det ikke noe fullt tverrspråklig performansesamsvar mellom de tyskspråkliges oppførsel i tysk og norsk, så dette kravet er ikke fullstendig bekreftet. Man kan tross alt påstå at det å ha tysk som morsmål virker fordelaktig på tilegnelsen av norsk samsvarsbøyning av adjektiviske attributter, og hindrende på tilegnelsen av norsk samsvarsbøyning av adjektiviske predikativer (iallfall i sammenligning med det å ha polsk og engelsk som morsmål).

\subsection{Oppsummering}

De polskspråklige informantenes performanse i norsk samsvarsbøyning av adjektiver viser at innlærerne ikke har større problemer med tilegnelsen av dette fenomenet siden adjektivkongruens stort sett er tilegnet av denne morsmålsgruppen. Den er i de fleste tilfellene korrekt, med noen få unntak som til sammen utgjør 7,4\% av alle adjektiver som gruppen brukte $\mathrm{i}$ kongruens. Feilene testtakerne gjorde avhenger for det meste av den grammatiske konteksten adjektivet befinner seg i, og ikke av adjektivet selv. Det betyr at det ikke finnes noen spesielt vanskelige adjektiver som er problematiske for innlærerne. Mens noen feil viser manglende kunnskaper i norsk samsvarsbøyning av adjektiver, er det en del feil som kan skyldes manglende kunnskaper i andre grammatikkområder i norsk (f.eks. definitte nominalfraser). Fordi tekstene informantene skrev, kommer fra friskriving, er antallet ulike grammatiske kontekster ulikt, og i flere tilfeller ganske begrenset (f.eks. det er veldig få eksempler på bruken av 
adjektiver i genitivfraser, i infinitivfraser, med at-setninger eller med subjekter med generisk referanse og i verbfraser med verbene føle seg og se ut). Det er høyst sannsynlig at slike fraser var unngått av informantene på grunn av deres vanskelighet.

Det er dessuten sjekket innflytelse av ulike faktorer på tilegnelse av norsk kongruensbøyning hos de polskspråklige informantene. Jeg har funnet bevis på påvirkning av tverrspråklig innflytelse, generelle norskkunnskaper og delvis av alder. Det å ha polsk som morsmål virker fordelaktig på tilegnelse av samsvarsbøyning av norske adjektiver (positiv transfer). Også det å generelt kunne norsk bedre (det å være på et høyere CEFR-nivå i norsk) påvirker performansen i norsk adjektivkongruens positivt. Når det gjelder alder, er det funnet en statistisk signifikant forskjell mellom de 30-39 år gamle og de 40-54 år gamle informantene, men ikke mellom de 19-29 år gamle og de 40-54 år gamle informantene, det kan altså ikke trekkes en konklusjon om at høyere alder virker fordelaktig på performansen i norsk adjektivkongruens. Noen påvirkning av utdanning, antall kurstimer i norsk, oppholdstid i Norge eller kunnskaper i engelsk som S3 på norsk kongruensbøyning ble ikke funnet / bekreftet. 


\section{Konklusjoner}

Hensikten med denne avhandlingen var å undersøke hvordan polskspråklige innlærere av norsk som andrespråk tilegner seg norsk adjektivkongruens. Jeg analyserte adjektiver i 200 tekster skrevet på norsk av polskspråklige personer ${ }^{64}$. I analysen så jeg både på selve adjektivene som ble kongruensbøyd, på den grammatiske konteksten kongruensen fant sted i, på språklig transfer fra morsmålet (som er en psykolingvistisk faktor) og på andre faktorer som jeg hadde antatt hadde innflytelse på innlærernes performanse i norsk samsvarsbøyning av adjektiver (de andre faktorene blir kalt for sosiale i denne sammenhengen). Formålet med dette kapittelet er først og fremst å diskutere analyseresultatene i lyset av forskningsspørsmålene og hypotesene jeg stilte i kapittel 2. Først skal jeg omtale adjektivene som ble bøyd ukorrekt av de polskspråklige innlærerne, så skal jeg drøfte resultatene som angår den grammatiske konteksten de polskspråklige informantene brukte kongruensbøyning $\mathrm{i}$, for så å komme til påvirkningen av den psykolingvistiske (transfer) og de sosiale faktorene. Det andre underkapittelet vil vise studieresultatene $\mathrm{i}$ lyset av undervisningsformål, og det siste underkapittelet vil vise i hvilken retning videre forskning på tilegnelsen av adjektivkongruens i norsk som S2 bør gå.

\subsection{Studieresultater}

\subsubsection{Adjektiver brukt ukorrekt av innlærerne}

Adjektivene som oftest ble bøyd ukorrekt av informantene, hører stort sett til det regelmessige bøyningsparadigmet og til det modifiserte bøyningsparadigmet (modifikasjoner av hovedregelen). Når det gjelder feilene $\mathrm{i}$ adjektivene med det modifiserte bøyningsparadigmet, forekom de vanligvis $\mathrm{i}$ situasjoner når modifikasjonen ikke gjaldt den gitte endelsen

64 Til transferanalysen brukte jeg dessuten 200 tekster skrevet av engelskspråklige og 200 tekster skrevet av tyskspråklige norskinnlærere. 
(f.eks. var flere feil gjort i adjektivet viktig ${ }^{65}$ hvor man enten ikke brukte endelsen -e når den behøvdes, eller når man brukte den når det ikke var behov for den). Det ser altså ut til at adjektivets tilhørighet til enten det regelmessige, modifiserte eller uregelmessige bøyningsparadigmet ikke har noe å gjøre med innlærerens suksess i å samsvarsbøye dette adjektivet. Likevel kan en psykologisk begrensning spille en rolle her: Innlæreren kan være spesielt oppmerksom på adjektivene med modifisert og avvikende bøyning (fordi hun husker at det er noe spesielt med disse adjektivene), noe som kan føre til at hun bruker dem med større forsiktighet og refleksjon. Dette kan i sin tur føre til at innlæreren prøver å unngå å gå i en felle når hun ser slike adjektiver, og da gjør hun feil. Denne hypotesen trenger imidlertid psykolingvistiske verktøy for å kunne påvises.

\subsubsection{Den grammatiske konteksten til kongruens}

De polskspråklige norskinnlærernes performanse i norsk adjektivkongruens ser ut å være vellykket generelt sett (dvs. at den samsvarer med det som er betraktet som normen i norsk bokmål), ettersom 92,6 \% av alle adjektivene informantene produserte, var bøyd korrekt. Testtakerne laget et bredt spekter ulike fraser med adjektiver. Noen av dem var svært hyppige (f.eks. substantivfraser med ett adjektiv som premodifikator som i: en varm genser), mens andre var sjeldne (f.eks. predikativer som betegner kjerner som er i generisk referanse som i: en ting er klart). Likevel viser suksessen i samsvarsbøyning seg å være forbundet med innlærerens korrekte eller mislykkete identifisering av samsvarsbøyningskonteksten, det vil si med hvorvidt innlæreren var klar over at det gitte adjektivet må bøyes i den gitte situasjonen eller ikke. Det finner

${ }^{65}$ Viktig hører til det modifiserte paradigmet ettersom adjektivet ikke kan få endelsen - $t$. Modifikasjonen påvirker altså ikke bruken av endelsen - $t$ i tilfellet viktig. 
altså sted to typer feil her ${ }^{66}$ : det å overse konteksten for samsvarsbøyning når den er til stede (noe som skjedde oftest), eller det å se konteksten der den ikke er til stede (en sjeldnere situasjon). Informantene brukte følgelig enten ingen adjektivendelse når en slik endelse (enten - $e$ eller $-t$ ) behøvdes, eller de brukte en endelse (enten - $e$ eller $-t$ ) når det ikke var behov for noen endelse ${ }^{67}$. Feilene berører alle kategoriene til adjektivet: begge tall, alle kjønn, ubestemt og bestemt form, og attributiv og predikativ stilling.

Når det gjelder feil gjort $\mathrm{i}$ adjektiver som står til substantiver i flertallsreferanse, forekommer slike feil både i attributiv og i predikativ stilling, men det er flere ukorrekt bøyde predikativer enn attributter ( 49 mot 21 forekomster). Den hyppigere frekvensen av slike feil i predikativ posisjon kan muligens forklares med Pienemanns prosessabilitetsteori og bekrefte resultater presentert av Glahn mfl. (2001) om at informasjonsutveksling først blir tilegnet innen fraser, så mellom fraser innen én setning, og til slutt mellom setninger. I min analyse skilte jeg ikke mellom predikativer innen én setning og predikativer i underordnete setninger, slik at steg 4 og 5 i Pienemanns (2003: 689) ${ }^{68}$ hierarki er slått sammen hos meg (først og fremst på grunn av et lite antall kongruensbøyde adjektiver brukt i underordnete setninger). En sammenligning av totalantallet kongruensfeil $\mathrm{i}$ attributiv og i predikativ posisjon viser imidlertid ingen signifikante forskjeller ${ }^{69}$, noe som igjen avkrefter Pienemanns prosessabilitetsteori i dette tilfellet. Jeg vil tross alt legge merke til at prosessering og

${ }^{66}$ Det forekommer også en tredje type feil hvor informantene forvekslet endelsen $-e$ og $-t$, men det er bare elleve slike feil i korpuset, derfor er de lagt mindre vekt på.

${ }^{67}$ Forutsetningen for at maskuline og feminine former er betraktet som null-kontekst for samsvarsbøyning, er gjort for metodologiske formål. Med dette vil jeg ikke henvise til generativ (regelbasert) lingvistikk som opererer med begrepet defaultgenus ettersom denne avhandlingen er bygget på kognitive andrespråkslæringsteorier hvor frekvens i innputt er viktigere enn regel, og hvor derfor ikke kan være snakk om defaultgenus (jf. Ragnhildstveit 2013).

${ }^{68}$ Se Prosesseringsseksjon i kapittelet Teoretisk tilnærming.

${ }^{69}$ Se Innenspråklige ulikheter i kapittelet Analyse. 
distansen mellom kontrolløren og adjektivet (som Lichtman 2009 undersøkte) kan ha sin innsats i innlærernes performanse i samsvarsbøyning av adjektiver som står til substantiver i flertall. En annen forklaring til hvorfor de polskspråklige informantene unnlater flertallsendelsen ved adjektiver i predikativ funksjon, kan være påvirkning av dialekter. Både nordnorsk og bergensk mangler flertallsendingen -e når adjektivet står til et flertallssubjekt etter verbene: vere/verte/bli (Papazian \& Helleland 2012: 123, Vigeland 1995: 37). Norskinnlærerne som bor i Nord-Norge eller i Bergen, kan altså ha tilegnet seg adjektivkongruensen som er gjeldende i de områdene de er boende i. I sitt hjerne gjør de slik sett ikke feil siden de bruker norsk analogt med den innputten de får (la meg igjen sitere innputtsdefinisjonen til Gass \& Selinker 2008: 304 som «the language to which learners were exposed $\rangle^{70}$ ), selv om formene de bruker, ikke er i samsvar med korrekt bruk av bokmål. ASK-korpuset gir imidlertid ingen informasjon om hvor $\mathrm{i}$ Norge informantene bor og har bodd.

En del feil de polskspråklige norskinnlærerne gjorde, var forårsaket av deres manglende viten om substantivets kjønn, noe som resulterte i enten bruk av en ukorrekt artikkel eller i å unngå artikkelbruk (som også var ukorrekt). I tilfellene når en ukorrekt artikkel ble brukt, og adjektivet ble samsvarsbøyd i henhold til artikkelen, (dvs. at det ble bøyd korrekt i henhold til artikkelen, men ukorrekt i henhold til substantivet), oppstår det et spørsmål om hva som er triggeren som utløser kongruensen: Er det substantivet, eller er det artikkelen? Mye tyder på at det nettopp er artikkelen som utløser kongruensen hos innlærerne, men denne avhandlingen betraktet jeg tross alt substantivet og ikke artikkelen som kongruenstrigger fordi substantivet er generelt omtalt som den vanligste kontrolløren i kongruens (ettersom det utgjør kjernen i substantivfraser, jf. bl.a. NRG 1997: 387). Derfor ble utsagn hvor innlærerne samsvarsbøyde adjektiver i henhold til artikkelen, og ikke til substantivet (som i disse tilfellene fikk ukorrekt tilskrevet kjønn), betraktet som

${ }^{70}$ Min framheving - M.O.J. 
feil i denne avhandlingen. Hypotesen om at en full tilegnelse av adjektivisk samsvarsbøyning i norsk som S2 er umulig før man har tilegnet seg genuskategorien, ser altså ut til å få bekreftelse her. Man må altså først kunne bygge substantivfraser som består av en artikkel + et substantiv korrekt, før man blir i stand til å bygge mer sammensatte fraser som består av en artikkel + et adjektiv + et substantiv. Tilegnelsen av adjektivisk kongruensbøyning er derfor strengt forbundet med tilegnelsen av genus.

En ganske vanlig type feil ved attributive adjektiver er å overse samsvarsbøyningskonteksten i definitte fraser (f.eks. i: det store huset). Problemet med slike feil er sammensatt. For det første, når slike fraser viser til entallsreferenter, kongruerer adjektivet ikke med substantivet $i$ henhold til kjønn, men får alltid endingen $-e$, noe som kan virke forvirrende for innlærerne. Likevel gjorde mine informanter bare to feil der de brukte entallsendelsen $-t$ istedenfor $-e$ i definitte fraser (bruken av ingen endelse $-\varnothing$ istedenfor $-e$ er et enda mer komplisert problem, ettersom man ikke ved hjelp av korpusdata kan avgjøre hva som var innlærernes hensikt med å ikke bøye adjektivet: om de ville bøye det i samsvar med substantivets genus, eller om de unngikk å bøye det av andre grunner, f.eks. manglende viten om oppbyggingen av bestemthetsfraser). Det kan tyde på at innlærerne enten visste at de ikke skulle samsvarsbøye adjektiver i henhold til substantivets kjønn i slike fraser (men istedenfor å bruke endelsen -e, unngikk de å bøye adjektivene $\mathrm{i}$ det hele tatt), eller at de slett ikke hadde lært seg oppbyggingen av definitte fraser. Den andre forklaringen kan vitne om innlærernes generelle problemer med definitte fraser (i tilfeller der de gjorde feil i adjektivisk samsvarsbøyning, og ikke totalt sett - i hele korpuset). I flere tilfeller unngikk de å bruke den definitte artikkelen og/eller å bøye substantivet $\mathrm{i}$ bestemt form. Det kan altså sies at tilegnelsen av adjektivisk kongruensbøyning forutsettes av tilegnelsen av bestemthetskategorien og tilegnelsen av oppbyggingen av definitte fraser $i$ norsk som S2. 
De polskspråklige norskinnlærernes performanse i norsk adjektivisk samsvarsbøyning var ukorrekt også i noen andre grammatiske kontekster. Det dreier seg om spesielle grammatiske strukturer hvor samsvarsbøyning ikke avhenger av substantivets kjønn, tall og (u-)bestemt form, men av andre prinsipper. Herunder faller først og fremst genitiv- og superlativfraser. Begge frasetyper virker problematiske for innlærerne, slik at de flere ganger gjør feil i disse frasene. En forskjell mellom disse to typene er at genitivfrasene med adjektiver ser ut å være underrepresentert i korpuset (noe som ikke er tilfellet ved superlativfraser). Det er til sammen 52 slike fraser laget av de polskspråklige informantene (hvorav 38 er korrekte). Adjektivene i genitivfraser utgjør 1,2\% av alle adjektivene brukt av de polskspråklige informantene. Dette kan indikere at denne typen fraser var unngått av informantene med hensikt, og forklaringen til dette kan være at genitivfraser med adjektiver er oppfattet som spesielt vanskelige av innlærere. Det kan altså forekomme negativ transfer her, som ifølge Odlin (1989: 36) kan ha sitt utslag i underproduksjon. Når det gjelder superlativfraser, har de en lignende struktur til bestemthetsfraser, og kan kanskje betraktes av innlærerne som like vanskelige som bestemthetsfraser.

En del andre grammatiske strukturer gir inntrykk av å være unngått i de polskspråkliges tekster. Her må det nevnes konstruksjoner med adjektiver i samsvarsbøyning med substantiver i generisk referanse (f.eks. i: en ting er klart) ${ }^{71}$, med infinitivfraser (f.eks. i: å skrive en melding er så populart) ${ }^{72}$, med at-setninger (f.eks. i: at det norske samfunnet er delt er sikkert) ${ }^{73}$, og etter verbene føle seg og se ut (f.eks. i: en familie føler seg veldig ensom) ${ }^{74}$. En stor del av adjektivene i slike konstruksjoner ble bøyd ukorrekt. Disse strukturenes relativt lave frekvens og relativt store feilandel kan igjen tyde på at de

${ }^{71}$ Informant s0955.

72 Informant h0658.

73 Informant h0664.

${ }^{74}$ Informant s0742. 
virker vanskelige for innlærerne, og derfor blir de unngått, noe som kan betraktes som utslag for negativ transfer i Odlins (1989: 36) forstand.

Basert på mitt datamateriale og analysen jeg har gjennomført, er det ikke mulig å bestemme en klar læringsløype og -rekkefølge som de polskspråklige norskinnlærerne tilegner seg den adjektiviske samsvarsbøyningen i norsk som S2 på. Det kan imidlertid sies at tilegnelsen av adjektivkongruensen i norsk som S2 er strengt forbundet med tilegnelsen av andre grammatiske kategorier og strukturer som er knyttet til adjektivkongruensen. Korrekt samsvarsbøyning av adjektiver forutsetter altså at innlæreren allerede har tilegnet seg genuskategorien, og kan bruke den korrekt, og at hun har tilegnet seg bestemthetskategorien, og kan bruke den korrekt. I tillegg til det kreves det at innlæreren har tilegnet seg andre grammatiske strukturer før hun er i stand til å bruke dem med adjektiver i kongruens (her er det snakk om bl.a. genitiv- og superlativfraser, konstruksjoner med adjektiver i samsvarsbøyning med substantiver i generisk referanse, med infinitivfraser, med atsetninger og etter verbene føle seg og se ut). En fullstendig tilegnelse av adjektivisk kongruens må derfor komme etter tilegnelsen av de grammatiske kategoriene og strukturene som er forbundet med den. Logisk virker hypotesen om at læringsløypen, det vil si etappene eller stegene som adjektivkongruens blir tilegnet i, vil gjenspeile læringsrekkefølgen adjektivkongruens er plassert i. Slik sett, dersom tallkategorien blir tilegnet før genuskategorien, og genuskategorien blir tilegnet før bestemthetskategorien, vil adjektivkongruens i tall tilegnes først, så vil det komme adjektivkongruens i genus, og til slutt adjektivkongruens i bestemthet. Denne hypotesen krever imidlertid en longitudinell studie hvor man vil overvåke tilegnelsen av flere grammatiske kategorier og strukturer samtidig, helst hos flere innlærere. 


\subsubsection{Den psykolingvistiske faktoren - transfer}

Tverrspråklig innflytelse er en faktor som spiller en stor rolle i tilegnelsen av adjektivkongruens i norsk som S2. Avhengig av hvorvidt innlærerens morsmål har adjektivkongruens eller ikke, vil innlæreren oppføre seg i norsk som S2 mer eller mindre korrekt når det gjelder samsvarsbøyning av adjektiver. I avhandlingen testet jeg tre hypoteser angående transfers påvirkning på norskinnlærernes performanse.

For det første testet jeg hypotesen om at takket være positiv transfer gjør de polskspråklige norskinnlærerne færre feil i adjektivisk samsvarsbøyning enn de engelskspråklige, på grunn av likheter mellom norsk og polsk og ulikheter mellom norsk og engelsk på adjektivkongruensområdet (både norsk og polsk har adjektivisk samsvarsbøyning $\mathrm{i}$ attributiv og predikativ stilling, mens ikke engelsk har adjektivisk samsvarsbøyning i det hele tatt). Denne hypotesen er blitt bekreftet gjennom analysen. Tre av fire krav Jarvis (2010) anser som nødvendige for å påvise tverrspråklig innflytelse, er oppfylt av denne morsmålsgruppen. Og det fjerde kravet er delvis oppfylt. De polskspråklige norskinnlærerne viser homogenitet som gruppe og skiller seg signifikant fra den engelskspråklige gruppen. Det betyr at variasjonen $i$ antallet feil gjort innen den polske S1-gruppen er mindre enn mellom denne gruppen og den engelske S1-gruppen. Kravet om intragruppe-homogenitet og intergruppe-heterogenitet er dermed oppfylt. Også kravet om innenspråklige ulikheter er oppfylt, for de polskspråklige informantene gjorde like mange feil i kongruens i attributiv posisjon som i predikativ (forskjeller i antallet feil er ikke statistisk signifikant i dette tilfellet og kan ha oppstått tilfeldig). Det eneste kravet fra Jarvis' (2010) metode som ikke ble oppfylt fullt her, er tverrspråklig performansesamsvar ${ }^{75}$. En sammenligning av innlærernes performanse i norsk som S2 og deres

${ }^{75}$ Det viser seg at dette kravet ikke kan oppfylles fullt $\mathrm{i}$ en undersøkelse av påvirkningen av transfer på kongruensbøyning, noe som kanskje kan tyde på 
hypotetiske performanse i polsk (som kan betraktes som en vanlig polskbruk) viser at bare en del av feilene innlærerne gjorde, er i samsvar med det som oppfattes som korrekt bruk av polsk. Det gjelder disse feilene som er betegnet som feil bruk av kongruens i analysen, det vil si tilfeller når de polskspråklige samsvarsbøyde de norske adjektivene i kontekster der det var overflødig. Endrer man analysemetoden i denne sammenhengen, blir det også mulig med en annen tolkning. I min analyse skiller jeg mellom kontekster og null-kontekster for adjektivisk samsvarsbøyning, noe som fører til at adjektiver i naken form (f.eks. god, stor, varm) betrakter jeg som ubøyd. Bøyde adjektiver er kun de som har enten - $e$ - eller - $t$-ending (f.eks. gode, store, varme, godt, stort, varmt). Dersom man betraktet nakne adjektivformer som bøyde former, ville man se at all korrekt utført kongruensbøyning av adjektiver er i samsvar med vanlig polskbruk, mens alle feilene de polskspråklige gjorde $\mathrm{i}$ norsk kongruensbøyning av adjektiver, ikke er i samsvar med polsk. Her ville det i tillegg oppstå et spørsmål om endelsesvarietet man har i norsk og polsk. Selv om adjektivkongruensen ser lik ut i begge språkene, brukes det ulike adjektivendelser, noe som også kan være en faktor man skulle ta hensyn til. Alt i alt, ved hjelp av den metoden jeg har brukt $i$ analysen, er kravet om tverrspråklig performansesamsvar delvis oppfylt. Siden de tre andre kravene er oppfylt, og det fjerde kravet er delvis oppfylt, vil jeg påstå at det det forekommer positiv transfer i de polskspråkliges performanse i norsk adjektivisk kongruensbøyning. Det å ha polsk som morsmål virker altså fordelaktig på tilegnelse av adjektivisk samsvarsbøyning av adjektiver i norsk som $\mathrm{S} 2$.

Den andre hypotesen om tverrspråklig innflytelse testet i analysen gjaldt negativ påvirkning fra S1-engelsk på de engelskspråklige norskinnlærernes performanse i adjektivkongruens (i sammenligning med de S1-polskspråklige). Denne

at denne typen observasjon ikke egner seg godt for studien om tverrspråklig innflytelse i kategorien samsvarsbøyning. 
hypotesen er også blitt bekreftet i analysen. Den S1-engelskspråklige gruppen oppfyller helt tre av Jarvis' fire krav om tverrspråklig innflytelse. Jeg har gitt bevis på denne morsmålsgruppens homogenitet (alle de engelskspråklige informantene oppførte seg likt når det gjelder samsvarsbøyning av norske adjektiver) og heterogenitet i forhold til den polske og tyske morsmålsgruppen - de engelskspråklige oppførte seg signifikant mindre korrekt (dvs. at de gjør flere feil) i adjektivisk samsvarsbøyning i norsk enn de polsk- og tyskspråklige. Kravet om intragruppe-homogenitet og intergruppe-heterogenitet er dermed oppfylt. Det er heller ikke funnet noen statistisk signifikant forskjell i antallet feil de engelskspråklige informantene gjorde $\mathrm{i}$ attributiv og predikativ posisjon (kravet om innenspråklige ulikheter er samtidig oppfylt). Den forskjellen som tross alt finnes $\mathrm{i}$ antallet feil $\mathrm{i}$ de to posisjonene, kan betraktes som tilfeldig. Også i dette tilfellet er kravet om tverrspråklig performansesamsvar delvis oppfylt, slik at det oppfylles bare $\mathrm{i}$ feilene som er betegnet som mangel på kongruens hvor adjektiver ikke ble samsvarsbøyd selv om det var behov for det. Analogt med det jeg skrev ovenfor om den metoden som ikke ble valgt $i$ analysen, hvor nakne adjektivformer også betraktes som bøyde former, er det naturlig å tro at dersom jeg hadde valgt den, ville jeg fått et litt annet resultat. I dette tilfellet ville all korrekt performanse i adjektivkongruens hos de engelskspråklige være et tegn på at fenomenet er tilegnet av dem, mens alle feilene i adjektivkongruens ville være betraktet som utslag for negativ transfer. Likevel kan man også ved bruk av den metoden jeg har valgt i analysen, bekrefte tilstedeværelsen av negativ transfer $\mathrm{i}$ performansen til de engelskspråklige norskinnlærerne. Det å ha engelsk som morsmål virker altså hindrende på tilegnelsen av norsk samsvarsbøyning av adjektiver, iallfall i sammenligning med det å ha polsk som morsmål.

Hypotesen om den tyske morsmålsgruppen er også bekreftet. Den, i likhet med de to andre S1-gruppene, tilfredsstiller Jarvis' (2010) tre av fire krav fullstendig, og det 
fjerde kravet i en viss grad. Kravet om intragruppe-homogenitet og intergruppe-heterogenitet er oppfylt, ettersom de tyskspråklige norskinnlærerne viser homogenitet når det gjelder feilantallet i norsk adjektivkongruens, og deres performanse er signifikant bedre enn performansen til den S1-engelske gruppen. Det er ikke funnet noen statistisk signifikant forskjeller mellom den tyske og polske S1-gruppen, noe som høyst sannsynlig er forårsaket av tilstedeværelsen av adjektivisk kongruens i begge språkene. De tyske norskinnlærerne skiller seg fra de to andre innlærergruppene $i$ at deres performanse $i$ samsvarsbøyning $i$ attributiv stilling er signifikant bedre enn den i predikativ stilling. Her ser man altså påvirkning av morsmålet hvor bare attributter, men ikke predikativer, kongruerer med kontrolløren. Kravet om innenspråklige ulikheter er derfor tilfredsstilt. Tverrspråklig performansesamsvar finner sted i de tyskspråkliges feil av typen mangel på kongruens der de ikke samsvarsbøyde norske adjektiver i predikativ stilling, og i feil av typen feil bruk av kongruens der de ikke samsvarsbøyde norske adjektiver i attributiv stilling. Kravet om tverrspråklig performansesamsvar er derfor oppfylt til en viss grad. Det kan også påstås at tverrspråklig innflytelse er en faktor som påvirker de tyskspråklige norskinnlærernes tilegnelse av adjektivisk samsvarsbøyning i norsk som S2. I sammenligning med det å ha engelsk som S1, er den tyske S1-innflytelse positiv. Likevel avhenger transferspåvirkningen av adjektivets funksjon i setningen. Det forekommer nemlig positiv transfer i tilfellet samsvarsbøyning av attributter og negativ transfer i tilfellet samsvarsbøyning av predikativer.

Et spørsmål som kan stilles under analysen, angår tilstedeværelsen av feil som de polskspråklige norskinnlærerne gjør i adjektivkongruensen i norsk som S2. Selv om det kan påvises påvirkning av positiv transfer på deres performansen, gjør de polskspråklige tross alt feil i samsvarsbøyning av norske adjektiver. Det kan forstås slik at den positive innflytelsen morsmålet har på innlærernes performanse i S2-norsk, ikke gir 
dem $100 \%$ garanti for at det ikke vil oppstå feil i samsvarsbøyning av adjektiver. Tilstedeværelsen av feil kan ha ulik forklaring. For det første kan den være forbundet med transferabiliteten. Som sagt i kapittel 2 påstår Kellerman (1979) at innlærerne overfører trekk fra et språk til et annet når de for det første vurderer kilde- og målspråket som like, og for det andre - når de ikke betrakter kildespråkets trekk som språkspesifikke (dvs. når de ikke oppfatter dem som prototypiske). Fordi norsk og polsk hører til to forskjellige språkfamilier (den germanske og den slaviske), og fordi språkene viser mange ulikheter, er det mulig at også polskspråklige norskinnlærere oppfatter de to språkene som ulike, og heller uvillig vil støtte seg på sine polskkunnskaper når de bruker norsk. Dessuten, siden bøyningsendelsene ved adjektiver er forskjellige i norsk og polsk, kan også adjektivkongruens oppfattes av innlærerne som språkspesifikk og umulig å overføre mellom språkene. Dette kan igjen føre til at transfereffekten er mindre enn den kunne vært. På den annen side kan likheter mellom norsk og engelsk oppfattes av de engelskspråklige norskinnlærerne som større enn de er i virkeligheten, slik at innlærerne kan tro at de er gjeldende også i adjektivkongruens. Hypotesen om hva som oppfattes som transferbart fra polsk og engelsk til norsk (og tysk), krever imidlertid å bli undersøkt psykolingvistisk.

Feil av typen mangel på kongruens som ikke er kongruent med vanlig polskbruk, kan kanskje skyldes transfer fra S3engelsk. Selv om det ikke er påvist noen fast påvirkning fra engelsk som S3 på de polskspråkliges performanse i norsk kongruensbøyning (faktoren kunnskaper i engelsk som S3 er tatt opp i seksjonen 5.2), er det mulig at det å kunne engelsk som andrespråk kan redusere den positive effekten morsmålstransferen har på de polskspråkliges tilegnelse av norsk adjektivkongruens. Denne forklaringen er imidlertid bare spekulativ så lenge den ikke er blitt testet empirisk.

En annen grunn til at det oppstår feil i adjektivbøyning, er adjektivendelsenes lille saliens. Endelsene er enkle lyder på slutten av ordene, de er ofte uttalt uklart eller til og oppslukt av 
den talende. Dessuten er det sjelden at de skaper forskjeller i setningens betydning (som f.eks. i: Hun svømte vakker/vakkert i bølgene). Berggreen og Tenfjord (1999: 90-94) påstår at saliens er en faktor som har innflytelse på at innputt blir til inntak. Når et språklig fenomen er lite salient, er det følgelig mindre sannsynlig at det i første omgang vil bli lagt merke til, og så bli til inntak, for å til slutt bli tilegnet. Adjektivkongruens, på grunn av dens lille saliens i norsk, kan derfor være oversett av innlærerne, særlig på begynnernivået, noe som igjen øker sannsynligheten til at feil på dette området oppstår.

Den mest trivielle årsaken til feilene, som heller ikke kan utelates, er stress, hastighet og vanlig slurv som ikke sjelden forekommer i en testsituasjon.

I transferanalysen tok jeg i betraktning bare to typer utslag som transfer kan gi i mellomspråk, det vil si positiv transfer og produksjonsfeil som utgjør en underkategori av negativ transfer. Ifølge Odlin (1989: 36) kan negativ transfer ha også andre utslag: underproduksjon, overproduksjon og mistolkning. Og ved siden av positiv og negativ transfer er det også snakk om endret tilegnelsestempo. Det sistnevnte utslaget av transfer er ikke mulig å bestemme ved hjelp av min analyse fordi man først må vite hvordan tilegnelsestempoet av adjektivkongruens i norsk som andrespråk er, før man kan undersøke transfers påvirkning på det. Her vil jeg heller ikke berøre mistolkning ettersom det heller oppstår i forståelsesoppgaver enn i produksjonsoppgaver. Når det derimot gjelder under- og overproduksjon, er det ikke mulig å måle uten at man har tekster skrevet av norsktalende personer som sammenligningsgrunnlag. Jeg kan altså ikke med sikkerhet fastslå at noen strukturer var unngått eller favorisert av informantene. Likevel fikk jeg i analysen en mistanke om at underproduksjonsprosessen hadde foregått, ettersom noen av (de mest kompliserte) strukturene forekom veldig sjelden i korpuset. Her er det snakk om genitivfraser, konstruksjoner med adjektiver i samsvarsbøyning med substantiver i generisk referanse, med infinitivfraser, med at-setninger og etter verbene føle seg og se ut. Som sagt ovenfor, bare en 
sammenligning med tekster skrevet av personer med norsk som S1 kan gi svar på om disse konstruksjonene ble underrepresentert i tekstene av de polskspråklige norskinnlærerne eller ikke. En annen sak er knyttet til graden adjektivene ble korrekt samsvarsbøyd i disse konstruksjonene. Andelen ukorrekt bøyde adjektiver er der stor og utgjør cirka $30 \%$, det vil si at den er fire ganger større enn ellers (andelen feil i kongruensbøyning gjort av de polskspråklige informantene utgjør $7,4 \%$ av alle samsvarsbøyningskontekster). Det ser altså ut til at disse konstruksjonene ikke er mestret av de polskspråklige, noe som fører til negativ transfer i dette tilfellet, enten i form av feilproduksjon eller unngåing. Denne påstanden trenger imidlertid å bli nærmere analysert og bekreftet.

Mitt funn om at transfer påvirker tilegnelsen av adjektivisk samsvarsbøyning, kan være et motargument mot blant annet Dulay, Burt og Krashens (1982: 102) påstand om at grammatiske (dvs. morfologiske og syntaktiske) transferfeil er relativt sjeldne. Samtidig er studien min i samsvar med det Jarvis og Odlin (2000) har gitt bevis på, nemlig «transferability of bound morphology», og støtter til en viss grad Odlins (2003) generelle prinsipp om at språklig transfer påvirker alle lingvistiske subdomener: pragmatikk, retorikk, semantikk, syntaks, morfologi, fonologi, fonetikk og ortografi. Resultatet fra min studie bidrar ikke bare til å bekrefte det generelle prinsippet, men gir også detaljer angående mekanismer og vilkår som tverrspråklig innflytelse forekommer under, på dette spesifikke og ofte benektete området - grammatisk morfologi som ikke sjelden var betraktet som redundant og blottet for betydning.

\subsubsection{De sosiale faktorene}

I analysen prøvde jeg å finne en korrelasjon mellom seks sosiale faktorer og de polskspråkliges performanse i adjektivisk kongruensbøyning i norsk som andrespråk. Disse faktorene var: generelle norskkunnskaper, alder, utdanning, antall kurstimer tatt i norsk, oppholdstid i Norge og kunnskaper i engelsk som 
S3. Blant disse viste bare generelle norskkunnskaper en klar tendens til å korrelere med innlærernes performanse i norsk samsvarsbøyning. Med økende norskkunnskaper gjorde informanter færre feil i adjektivbøyningen. Det viste seg å være et generelt trekk i de polskspråkliges mellomspråk at de gjorde færre feil i adjektivisk samsvarsbøyning på B2-nivået og oppover enn på B1-nivået og nedover. Man kan derfor si at tilegnelsen av adjektivkongruensen kommer relativt sent $\mathrm{i}$ utviklingen av norsk som S2, nemlig på B2-nivået. Å samsvarsbøye adjektiver i S2-norsk krever altså «relativt stor grad av grammatisk kontroll» (Rammeverket 2011: 36). Ettersom negativ transfer pleier å minske med økende mestring av målspråket, mens positiv transfer samtidig øker, ifølge Jarvis og Pavlenko (2008: 202-203), er det naturlig å anta at bedre generelle norskkunnskaper fremmer påvirkningen av positiv transfer hos de polskspråklige norskinnlærere. Bedre norskkunnskaper påvirker altså tilegnelsen av norsk adjektivkongruens primært av seg selv, og sekundært gjennom økt positiv transfer fra morsmålet.

Til tross for at jeg har funnet en viss sammenheng mellom alder og tilegnelsen av adjektivkongruens i norsk som S2, kan denne sammenhengen ikke betraktes som en korrelasjon mellom denne faktoren og tilegnelsen. En statistisk signifikant forskjell er funnet mellom de 30-39 år gamle og de 40-54 år gamle informantene (de eldste gjorde færre feil enn de yngste), men ikke mellom de 19-29 år gamle og de 40-54 år gamle informantene, og heller ikke mellom de 19-29 år gamle de 3039 år gamle (de yngste gjorde færre feil enn de eldste). Antallet feil i adjektivkongruens synker ikke med økende alder. Det er imidlertid lite forskning om tilegnelsen av andrespråk av ulike voksne aldersgrupper. Snow og Hoefnagel-Höhles (1978) tese om at: «Older is faster, but younger is better» kan nok ikke brukes i dette tilfellet uten videre. Man kan imidlertid tenke seg at språktilegnelse i yngre så vel som eldre alder har sine fordeler og ulemper, og er kanskje knyttet til individuelle erfaringer og motivasjon. 
Det er ikke funnet noen korrelasjon mellom utdanningsnivået og antallet feil i samsvarsbøyning. I ASL er det hittil imidlertid ikke funnet bevis på at en slik korrelasjon finnes. Som R. Ellis poengterer (1994: 204), har utdanningsnivået man har, innflytelse på klassetilhørighet. Riktignok påstår R. Ellis (1994: 205) og Gass og Selinker (2008: 420) at det er en positiv korrelasjon mellom ens foreldres utdanningsnivå og sosialklasse og ens suksess i å tilegne seg et andrespråk, men i tilfellet voksne innlærere er det vanskelig å ta $\mathrm{i}$ betraktning utdanningsnivået til innlærernes foreldre. For øvrig gir ASK-korpuset ingen informasjon om informantenes foreldres utdanning. Når det gjelder alder som en mulig faktor som påvirker tilegnelsen av et $\mathrm{S} 2$, vil studien min ikke tilføye noen nye funn.

Når det gjelder antallet kurstimer i norsk informantene hadde tatt, og oppholdstid i Norge før de tok prøven, kan de kanskje omtales sammen ettersom de i grunnen måler det samme, nemlig lengden på språkopplæring. Forskjellen mellom de to faktorene er at antallet kurstimer i norsk refererer til eksplisitt læring, mens oppholdstid i Norge refererer til implisitt læring. Jeg har ikke funnet korrelasjon med de polskspråkliges performans i norsk adjektivkongruens i noen av tilfellene. R. Ellis (2012: 81) sier at instruert opplæring kan påvirke tempoet som innlæreren når til etterfølgende etapper i en læringsløype og -rekkefølge, selv om den ikke påvirker selve læringsløypen og -rekkefølgen i S2-tilegnelsen. Fordi tilegnelsestempoet av adjektivkongruens i norsk som andrespråk ikke er kjent ennå, kan man heller ikke måle i hvilken grad instruert opplæring endrer den. At jeg ikke kunne påvise korrelasjonen mellom oppholdstiden i Norge og tilegnelsen av adjektivkongruens, kan kanskje virke overraskende. Likevel har andre studier lagt vekt på et annet aspekt av denne saken, nemlig på daglig bruk av S2 (som oftest er forbundet med oppholdstid i S2-landet) som viste seg å fremme S2-tilgenelsen (f.eks. i studien til Flege, Birdsong, Bialystok, Mack, Sung \& Tsukada 2006). En annen sak er viktig å poengtere her. Guion, Flege, Liu og Yeni-Komshian (2000b) har påvist at negativ S1-transfer blir redusert med økende 
oppholdstid i S2-landet. Det er altså mulig at påvirkningen av oppholdstid i Norge har en sekundær innflytelse på tilegnelsen av adjektivkongruens i norsk som S2 gjennom positiv transfer. Dette er imidlertid bare en hypotese som ikke er blitt sjekket ennå.

Den siste faktoren jeg har undersøkt påvirkning på tilegnelsen av adjektivkongruens i norsk som S2 av, er kunnskaper i engelsk som S3. Heller ikke denne faktoren viser korrelasjon med tilegnelsen av samsvarsbøyning av norske adjektiver. Likevel, som allerede drøftet, er det mulig at kunnskaper i engelsk som S3 kan redusere den positive effekten morsmålstransferen har på de polskspråkliges tilegnelse av norsk adjektivkongruens. Det kan være en av årsakene til at de polskspråklige norskinnlærere tross alt gjør feil i norsk samsvarsbøyning. Problemet med at jeg ikke fikk bevist påvirkningen av S3-engelsk på tilegnelsen av norsk samsvarsbøyning, kan ligge i metoden som er valgt til analysen. Påvirkning av et tredjespråk er egentlig også tverrspråklig innflytelse som følgelig krever å anvende en metodologi som passer til transferanalysen, for eksempel den som Jarvis (2010) og Jarvis og Pavlenko (2008) har foreslått. For å gjennomføre en slik analyse trenger man imidlertid et mer omfattende datamateriale, for eksempel tekster skrevet av innlærerne både på S2 og S3. Slike individuelle opplysninger om egne engelskkunnskaper som finnes i ASK, er ikke tilstrekkelige til å gjennomføre en ordentlig transferanalyse.

\subsection{Konklusjoner for didaktiske formål}

Jeg vil påstå at studien min har to viktige konklusjoner for didaktikken. Den første er kongruenstilegnelsens avhengighet av tilegnelsen av andre grammatiske kategorier og strukturer, og den andre er rollen som positiv transfer spiller i tilegnelsen av adjektivisk samsvarsbøyning i norsk som andrespråk.

Resultatene fra undersøkelsen tyder på at tilegnelsen av norsk samsvarsbøyning er strengt forbundet med tilegnelsen av 
kategoriene de norske adjektivene kongruerer i, det vil si tall, genus og bestemthet. Fordi jeg ikke har noen bevis på at numeruskategorier skaper problemer for de polskspråklige, utelukker jeg denne kategorien fra drøftelsen nedenfor. Siden samsvarsbøyning av norske adjektiver krever forståelsen og bruken av både genus og bestemthet, er riktig bruk av disse to kategoriene nødvendig i samsvarsbøyningen. Det er altså ikke mulig at innlærere vil samsvarsbøye adjektiver korrekt før de har lært seg genus- og bestemthetskategorien. I undervisningen er det derfor meningsfullt å innføre og øve på genus og bestemthet før adjektivkongruensbegrepet blir innført. Dessuten er jeg overbevist om at innføring av samsvarsbøyningsbegrepet vil kreve en repetisjon og ny forklaring av genus- og bestemthetskategorien, ettersom innlærerens forrige viten må bygges om ved introduksjonen av kongruensbegrepet. Adjektivkongruens forekommer i tillegg i noen konstruksjoner som, slik det ser ut fra studien min, virker kompliserte for innlærerne. Her tenker jeg først og fremst på genitivfraser med adjektiver og konstruksjoner med adjektiver i samsvarsbøyning med substantiver i generisk referanse, med infinitivfraser, med $a t$-setninger og etter verbene føle seg og se ut. Disse grammatiske strukturene trenger mye øving og en eksplisitt problematisering når de opptrer med adjektiver. I samsvar med det Norris og Ortega (2000: 417-418) påstår, er det å forvente at en eksplisitt instruks vil bringe nytte for innlæreren: «the effectiveness of L2 instruction is durable and that the type of outcome measures used in individual studies likely affects the magnitude of observed instructional effectiveness».

I undervisningen kan man dra nytte av likheter mellom norsk og polsk som finnes i adjektivisk samsvarsbøyning. Det å framheve likheter og problematisere ulikheter kan bidra til innlærernes bedre og raskere tilegnelse av adjektivkongruensen i S2-norsk. Læreren bør dessuten ikke glemme påvirkningen av positiv transfer i tilegnelsen av norsk kongruensbøyning. Det nytter å oppmuntre de polske norskinnlærerne til å støtte seg på sine polskkunnskaper i tilfellet adjektivisk samsvarsbøyning. 
Man må imidlertid ikke glemme at tilegnelsen av adjektivkongruensen kommer ganske sent i utviklingen av norsk S2. Selv om det er en signifikant forskjell på innlærerne på B2- og B1-nivået (de på høyere nivå gjør færre feil), forekommer feil i samsvarsbøyning på begge nivåene. Man kan derfor ikke forvente feilfrie tekster (iallfall når det gjelder kongruensbøyning av adjektiver) opp til B2-nivået.

\subsection{Videre forskning}

Denne studien er første forsøk i å forklare tilegnelsen av adjektivisk samsvarsbøyning i norsk som S2 og har ikke gitt svar på alle spørsmål som angår fenomenet. Det er derfor nødvendig med videre forskning på dette området. Basert på resultatene fra min studie vil jeg påstå at videre forskning må ta hensyn til fire aspekter som drøftes nedenfor.

For det første trengs det en psykolingvistisk undersøkelse som vil teste noen av hypotesene jeg har stilt i løpet av min analyse, blant annet hvordan innlærerne tilegner seg adjektiver med regelmessig, modifisert og avvikende bøyning, om de betrakter adjektiver med ulik type bøyning på ulik måte, eller tvert imot. Et annet viktig spørsmål som må besvares, gjelder hva som utløser kongruensen hos innlærerne: Er det artikkelen, substantivet eller noe helt annet? Et svar på dette spørsmålet vil sikkert gi et nytt synspunkt på undervisningen av norsk som andrespråk. Videre kan man se på hvordan de polskspråklige norskinnlærerne oppfatter distansen mellom norsk og polsk, om de ser på begge språkene som heller like hverandre, eller som forskjellige. Den oppfattete distansen mellom språkene har påvirkning på transferforekomsten, og den kan kanskje modifiseres gjennom undervisning i språktypologi.

Videre vil en longitudinell undersøkelse av læringsløypen og -rekkefølgen av tilegnelsen av adjektivkongruens i S2-norsk gi mye ny kunnskap om kongruenstilegnelsen. Bare ved å undersøke innlærere over en lengre periode vil kunne gi mer innsikt i hvordan utviklingsmønstre i norsk som andrespråk ser 
ut. En slik studie vil gi størst verdi dersom den kombineres med forskningen på tilegnelsen av tall-, genus- og bestemthetskategorien, ettersom disse fenomenene er uunnværlig forbundet med hverandre. Dersom man vet hvordan tilegnelsestempoet av kongruens er, kan man videre forske på hvilke faktorer som framskynder tempoet. Først og fremst kan man da teste påvirkningen av transfer og antall kurstimer i norsk.

En annen sak man kan undersøke, gjelder påvirkningen av dialekter på tilegnelsen av kongruensbøyning i norsk. Fordi det nettopp er dialekter mennesker i Norge snakker, og norskinnlærerne hører daglig, kan man anta at innlærerne som bor i ulike landsdeler, tilegner seg ulike dialektale trekk siden det er talemål som er innputten $\mathrm{i}$ de fleste tilfellene. Dialekten innlærerne hører, kan derfor ha en direkte innflytelse på deres norsktilegnelse.

Til slutt vil jeg nevne en mulig unngåing av grammatiske strukturer som kan oppfattes som vanskelige av innlærerne. Som sagt ovenfor kan en sammenligning av tekster skrevet av morsmålsbrukere av norsk og polsk (og kanskje også andre språk) vise om kompliserte strukturer er unngått av S2-innlærerne. Jeg håper imidlertid at studien min vil bli et godt utgangspunkt til videre arbeid med kongruenstilegnelsen i norsk som andrespråk. 


\section{Sammendrag på polsk (streszczenie)}

Niniejsza rozprawa, zatytułowana Odmiana przymiotnika $w$ języku norweskim - akwizycja kongruencji przymiotnika $u$ polskojęzycznych uczacych się języka norweskiego, jest w pewnym stopniu częścią norweskiego projektu badawczego ASKeladden ${ }^{76}$. Praca powstała w ramach dyscypliny naukowej akwizycja języka norweskiego jako drugiego, która należy do dziedziny naukowej akwizycja języka drugiego (ang. Second Language Acquisition - SLA). Mimo że SLA stała się już autonomiczną dyscypliną naukową (Ortega 2013: 2), to nadal jest stosunkowo nową dziedzina która ciągle się rozwija i nadal potrzebuje dowodów na potwierdzenie swoich teorii. Jej dynamiczny rozwój w ostatnich latach jest w dużej mierze rezultatem coraz większej potrzeby dwujęzyczności we współczesnym świecie (Tenfjord \& Berggreen 1999: 15) i związanych z nią procesów lingwistycznych, psycholingwistycznych i społecznych (Doughty \& Long 2003b: 4-7). W ostatnich latach również w społeczeństwie norweskim nasiliły się kontakty z innymi językami (spowodowane częstszymi podróżami, migracją ludności i rozwiązaniami technologicznymi ułatwiającymi kontakt ponad granicami państw), w związku z czym pojawił się problem dwujęzyczności i związana z nim potrzeba dwujęzycznej komunikacji (Sandøy \& Tenfjord 2006: 7). Pierwszą badaczką akwizycji języka drugiego w Norwegii jest Kari Tenfjord, która w 1997 obroniła rozprawę doktorską poświęconą podłużnemu badaniu przyswajania norweskich czasów przeszłych u wietnamskojęzycznych (L1) ${ }^{77}$ dzieci (Johansen et.al. 2010: 5).

Głównym celem mojej rozprawy jest zbadanie procesu akwizycji kongruencji norweskich przymiotników przez

76 Projekt został zakończony wiosną 2014 roku, a jego głównym celem było badanie wpływu transferu na przyswajanie języka norweskiego jako drugiego.

${ }^{77} \mathrm{~L} 1$ = język ojczysty, ang. First Language. 
polskojęzycznych uczących się języka norweskiego jako L2 ${ }^{78}$. W tym celu po pierwsze przedstawiam stan ich kompetencji w odmianie norweskich przymiotników w składni zgody, a po drugie ustalam, jakie czynniki z nią korelują. Czynniki te podzieliłam na psycholingwistyczne, lingwistyczne i społeczne (szeroko rozumiane). Zostaną one szerzej omówione w dalszej części streszczenia.

Praca składa się z sześciu rozdziałów. Rozdział pierwszy stanowi wstęp do dalszych rozważań. Przedstawiam w nim swoją motywację do podjęcia badań nad zjawiskiem akwizycji kongruencji przymiotników. Dużą rolę w decyzji o podjęciu się tego tematu odegrały zajęcia ze studentami pierwszego i trzeciego roku studiów licencjackich filologii norweskiej Uniwersytetu Adama Mickiewicza w Poznaniu, które prowadziłam w roku akademickim 2010/2011. Podczas zajęć zauważyłam, że poprawna odmiana przymiotników w składni zgody sprawia problem studentom, również tym z trzeciego roku. Błędy pojawiały się zarówno w wypowiedziach ustnych, jak i pisemnych i to pomimo wielu moich uwag i objaśnień. W licznych testach, które pisali studenci, poziom błędów utrzymywał się na poziomie $20-25 \%$. Wyniki jednego z nich postanowiłam przedstawić we wstępie do niniejszej rozprawy ${ }^{79}$. Test ten napisało 21 studentów drugiego roku studiów licencjackich filologii norweskiej na UAM. Był on częścią innego sprawdzianu i polegał na uzupełnieniu luk odpowiednio odmienionymi przymiotnikami, które weszłyby w składnię zgody z rzeczownikami, zaimkami osobowymi i w jednym przypadku ze słowem begge (= oboje, obie, obydwaj). Przymiotniki zostały przeze mnie wcześniej usunięte z przedstawionych dziewięciu zdań i podane $\mathrm{w}$ formie nieodmienionej w nawiasach. Poziom błędów w tym teście wyniósł 29\%. Ponieważ moi studenci byli w przeważającej większości osobami zdolnymi i szybko uczącymi się, doszłam do wniosku, że popełniane przez nich błędy w stosowaniu kongruencji norweskich przymiotników

${ }^{78}$ L2 = język drugi, ang. Second Language.

${ }^{79}$ Znajduje się on również w aneksie (Vedlagg na str. 263). 
nie wynikają z braku umiejętności, lecz z pewnych, ewidentnie problematycznych, cech kongruencji norweskich przymiotników, która pozornie wydaje się łatwa do opanowania, jako że wybór końcówek fleksyjnych jest niewielki w tym języku: $\varnothing$, - $e$ i $-t$. W projekcie doktorskim postanowiłam zatem zbadać interjęzyk (ang. interlanguage, zdefiniowany przez R. Ellisa 2012: 31 jako mental system of L2 knowledge reflected by the systematic development of learner language) polskojęzycznych uczących się języka norweskiego i w tym w celu zbadać proces akwizycji kongruencji norweskich przymiotników.

Interjęzyk jest pojęciem stworzonym przez kognitywnych badaczy akwizycji języka drugiego i właśnie na kognitywnych teoriach przyswajania języka, które zostały szeroko opisane w drugim rozdziale, opiera się niniejsza rozprawa. Teorie te podtrzymują, że przyswajanie języka drugiego niczym nie różni się od uczenia się wszelkich innych czynności, na przykład prowadzenia samochodu (Berggreen \& Tenfjord 1999: 291), i odpowiadają za nie te same procesy poznawcze. Według kognitywistów, uczący się w trakcie akwizycji języka rozwija w swoim umyśle pewien system językowy, który właśnie nazywany jest interjęzykiem. Należy jednak podkreślić, że mimo że interjęzyk przypomina błędną wersję języka docelowego oraz mimo że nosi wspólne cechy języka źródłowego i docelowego, nie należy go traktować jako tę 'gorszą, błędną wersję' języka docelowego, lecz jako w pełni autonomiczny system językowy, który rządzi się własnymi regułami (Tenfjord 1997: 243).

$\mathrm{Na}$ rozwój interjęzyka mają wpływ różne czynniki, $\mathrm{z}$ których R. Ellis (2012) wymienia między innymi: psycholingwistyczne (np. transfer językowy i operacje przetwarzania - processability), lingwistyczne (np. frekwencja, nacechowanie), społeczne (np. częstotliwość używania L2) i indywidualne (np. wiek, motywacja). W mojej analizie czynniki indywidualne zostały scalone ze społecznymi, tak więc używam wspólnej nazwy społeczne w odniesieniu do obu rodzajów czynników. 
Żeby osiągnąć główny cel projektu doktorskiego, to jest zbadać proces akwizycji odmieniania norweskich przymiotników w składni zgody przez polskojęzycznych uczących się języka norweskiego jako L2, postawiłam sobie pytania badawcze dotyczące:

1) roli transferu w przyswajaniu norweskiej kongruencji,

2) korelacji czynników społecznych (wybrałam następujące sześć: ogólny poziom biegłości językowej mierzony w skali $\mathrm{CEFR}^{80}$, wiek, wykształcenie, liczba godzin kursu językowego, długość pobytu w Norwegii, znajomość języka angielskiego jako L3) z liczbą błędów popełnianych w kongruencji norweskich przymiotników przez polskojęzycznych uczących się .

3) czynników lingwistycznych mogących mieć wpływ na performancję polskojęzycznych uczących się (tutaj zwracam uwagę zarówno na kontekst gramatyczny, w którym przymiotnik się znajduje, jak i na paradygmat odmiany, do którego należy dany przymiotnik).

Rozdział drugi kończę postawieniem hipotez badawczych. Pierwszą z nich jest to, że pozytywny wpływ na akwizycję kongruencji norweskiego przymiotnika będą miały:

1) wyższy poziom biegłości językowej mierzony w skali CEFR,

2) niższy wiek uczących się,

3) wyższy poziom wykształcenia,

4) odbycie większej liczby godzin kursu językowego,

5) dłuższy pobyt w Norwegii,

6) wyższy poziom znajomości języka angielskiego jako L3.

80 CEFR $=$ the Common European Framework of Reference for Languages: Learning, Teaching, Assessment. 
Kolejne hipotezy dotyczą wpływu transferu językowego na rodzimych użytkowników języków polskiego, angielskiego- i niemieckiego uczących się norweskiego. Tutaj zakładam:

1) oddziaływanie pozytywnego transferu na performancję polskojęzycznych uczących się (w porównaniu z angielskojęzycznymi), spowodowane podobieństwem użycia składni zgody w języku polskim i norweskim (w obu językach przymiotniki są odmieniane w składni zgody zarówno w pozycji przydawki, jak i orzecznika),

2) oddziaływanie negatywnego transferu na performancję angielskojęzycznych uczących się (w porównaniu z polskojęzycznymi), spowodowane różnicami użycia składni zgody w języku angielskim i norweskim (angielskie przymiotniki nie odmieniają się w składni zgody),

3) oddziaływanie pozytywnego transferu na performancję w odmianie norweskich przydawek u niemieckojęzycznych uczących się (w porównaniu z angielskojęzycznymi) spowodowane funkcjonowaniem przydawek w składni zgody w języku niemieckim i norweskim oraz jednoczesne oddziaływanie negatywnego transferu na performancję w odmianie norweskich orzeczników spowodowane brakiem funkcjonowania orzeczników w składni zgody w języku niemieckim u niemieckojęzycznych uczących się (w porównaniu z polskojęzyczny$\mathrm{mi})$

Ponieważ wpływ czynników językowych analizuję w badaniu jakościowym, nie postawiłam w ich przypadku żadnych hipotez, jedynie następujące pytania badawcze:

1) Jakie typy błędów w kongruencji popełniają polskojęzyczni uczący się języka norweskiego? Jakie końcówki fleksyjne mylą? Co jest przyczyną tych błędów? 
2) Jaki jest gramatyczny kontekst błędów? Czy tendencją jest, że częściej dochodzi do błędów w formach nieokreślonych/ określonych, liczbie pojedynczej/mnogiej, w funkcji przydawki/orzecznika? W jakich kontekstach gramatycznych przymiotniki są odmieniane poprawnie? Czy istnieją jakieś kategorie gramatyczne, w których uczący się częściej lub rzadziej popełniają błędy?

3) Jakie właściwości mają przymiotniki, które najczęściej są odmienione błędnie? Czy należą do regularnego paradygmatu odmiany, czy raczej wykazują odstępstwa od reguły?

Trzeci rozdział niniejszej pracy ma funkcję pomocniczą. Ustalam w nim definicję operacyjną przymiotnika. Za przymiotniki uważam zatem słowa, które: 1) denotują pojedyncze cechy, 2) funkcjonują zarówno w funkcji przydawki, jak i orzecznika w zdaniu, 3) można stopniować i odmieniać w składni zgody. Z klasy przydawek odrzucam imiesłowy, rzeczowniki, przysłówki, zaimki dzierżawcze i liczebniki (z wyjątkiem første $=$ pierwszy). $\mathrm{W}$ tej części pracy podaję również definicję kongruencji, która stanowi podstawy analizy. Zgodnie z definicją, którą podaje Corbett, kongruencją (ang. agreement) określa się sytuację gramatyczną, w której «one word can carry the grammatical meaning relevant to another» (Corbett 2006: 1). Obszerną część rozdziału trzeciego stanowi opis właściwości syntaktycznych i morfologicznych norweskiego przymiotnika oraz przedstawienie paradygmatów odmiany przymiotników wraz $\mathrm{z}$ wyjaśnieniem, kiedy stosuje się każdy z paradygmatów .

W czwartym rozdziale przedstawiam materiał badawczy i metodologię użytą do jego analizy. Materiał badawczy rozprawy stanowią dane $\mathrm{z}$ korpusu ASK (The Norwegian Language Learner Corpus) stworzonego na Uniwersytecie w Bergen przez grupę badawczą ASKeladden, która bada wpływ transferu językowego na naukę norweskiego jako L2. Korpus zawiera teksty napisane w języku norweskim jako L2 przez 
uczących się tego języka posługujących się dziesięcioma różnymi językami ojczystymi (albańskim, angielskim, niderlandzkim, polskim, rosyjskim, serbsko-chorwackim, somalijskim, hiszpańskim, niemieckim, wietnamskim). W każdej grupie L1 znajduje się 200 tekstów (z wyjątkiem albańskiego, somalijskiego i wietnamskiego - ze względu na brak wystarczającej liczby egzaminowanych). Teksty znajdujące się w korpusie zostały sprawdzone przez doświadczonych egzaminatorów i sklasyfikowane według poziomu biegłości CEFR. Części mowy zostały otagowane automatycznie, a błędy językowe - manualnie przez egzaminatorów. Teksty te można czytać w całości, co umożliwia, obok oczywistej w przypadku badań korpusowych analizy kwantytatywnej, również analizę jakościową, z której to możliwości skorzystałam.

W zależności od charakteru pytania badawczego zastosowałam w analizie trzy metody badawcze: jakościową, ilościową (statystyczną) i transferową, która łączy w sobie dwie pozostałe. Za pomocą metody jakościowej analizuję performancję $\mathrm{w}$ zakresie odmiany norweskich przymiotników w składni zgody u polskojęzycznych uczących się języka norweskiego. Biorę tutaj pod uwagę zarówno błędy, jak i użycie poprawne. Główny nacisk kładę jednak na błędy, które podzieliłam na trzy kategorie: 1) brak kongruencji (tj. nieużycie końcówki, kiedy jest wymagane zastosowanie - $t$ lub -e), 2) złe zastosowanie kongruencji (tj. użycie $-t$ lub $-e$, kiedy żadna końcówka nie jest wymagana), oraz 3 ) niepoprawna końcówka (tj. użycie - $t$ zamiast - $e$ lub na odwrót). Taki podział błędów jest możliwy, gdyż w analizie odróżniam kontekst dla kongruencji (tj. kiedy jest wymagane zastosowanie końcówki - $t$ lub -e) od zerowego kontekstu dla kongruencji (tj. kiedy nie jest wymagane zastosowanie końcówki, np. w przypadku orzeczników stojących w składni zgody z męskimi lub żeńskimi rzeczownikami w liczbie pojedynczej). Poprzez analizę jakościową staram się odpowiedzieć na powyżej przedstawione pytania badawcze dotyczące kontekstu gramatycznego, w którym dochodzi do błędów. 
Do badania korelacji między czynnikami społecznymi a błędami popełnionymi w odmianie przymiotników zastosowalam metodę statystyczną. Wykorzystałam tutaj trzy testy statystyczne: test Kruskala-Wallisa, test Manna-Whitney'a (jako post-hoc test dla testu Kruskala-Wallisa) i test Wilcoxona. Wszystkie te testy są testami nieparametrycznymi, ponieważ $\mathrm{w}$ badanej próbie nie stwierdziłam obecności normalnej dystrybucji, co sprawdziłam za pomocą testu Shapiro-Wilka. W przypadkach, kiedy wykonywałam kilka razy ten sam test na tej samej próbie statystycznej, stosowałam poprawkę Bonferroniego.

Osobna metoda została zastosowana do sprawdzenia wpływu transferu na akwizycję kongruencji przymiotników. Została ona zaczerpnięta z Jarvisa i Pavlenko (2008) oraz Jarvisa (2010) i opiera się na czterech rodzajach obserwacji: homogeniczności wewnątrzgrupowej (intragroup homogeneity), heterogeniczności międzygrupowej (intergroup heterogeneity), międzyjęzykowej zgodności w performancji (crosslinguistic performance congruity) i kontrastu wewnątrzjęzykowego (intralingual contrast). Pierwsze dwa rodzaje obserwacji bada się zazwyczaj za pomocą wspólnych narzędzi statystycznych. Polegają one na wykazaniu, że wariancja wewnątrz jednej grupy L1 jest mniejsza niż wariancja między tą grupą i inną grupą (innymi grupami) L1, które to grupy różnią się między sobą występowaniem badanego zjawiska językowego (Jarvis \& Pavlenko 2008: 46). Obserwowanie międzyjęzykowej zgodności $w$ performancji ma charakter jakościowy i polega na porównaniu użycia badanych zjawisk językowych w języku źródłowym i docelowym uczących się. Idealne badanie zakłada porównanie performancji tych samych użytkowników języków w ich L1 i L2, ale ze względu na to, że nie zawsze jest to osiągalne, możliwe są też inne rozwiązania (Jarvis \& Pavlenko 2008: 47). Ponieważ korpus ASK nie zawiera wypowiedzi badanych w ich językach ojczystych, porównuję ich performancję w L2 z ich hipotetycznymi wypowiedziami w ich L1. Hipotetyczne wypowiedzi są tłumaczeniami błędnych zdan, 
które badani napisali w języku norweskim, na ich języki ojczyste, to jest polski, angielski i niemiecki. Zdania thumaczyłam osobiście, w przypadku tłumaczeń na angielski i niemiecki konsultowałam się albo z rodzimymi użytkownikami tych języków, albo z filologami mającymi w tych językach kompetencje zbliżone do natywnych. Obserwacja kontrastu wewnątrzjęzykowego polega na po pierwsze podzieleniu danego zjawiska językowego na struktury, które inaczej są stosowane w L1 i L2 uczących się (w tej kwestii metoda ma charakter jakościowy), a po drugie na sprawdzeniu, czy zachowanie badanych w użyciu tych struktur w L2 jest podobne do użycia tych struktur w L1 (co można zrobić zarówno za pomocą badania jakościowego, jak i statystycznego, którym się posłużyłam). Rygor metodologiczny wymaga potwierdzenia wszystkich czterech typów obserwacji, ale ponieważ nie zawsze jest to możliwe i ponieważ wyżej opisane obserwacje są ze sobą powiązane, w niektórych przypadkach jedną $\mathrm{Z}$ obserwacji można zastąpić innymi (Jarvis 2010: 182).

W analizie postanowiłam skupić się przede wszystkim na błędach w kongruencji przymiotników (wyjątek stanowi tutaj kwalitatywna część analizy, gdzie po uwagę biorę również poprawne użycie). Decyzja ta jest motywowana przede wszystkim spojrzeniem na błędy i poprawne użycie jak na dwie strony tego samego zjawiska, w związku z czym badając jedno, można również scharakteryzować drugie. Każdy przymiotnik był oznaczony w analizie jako albo błędnie, albo poprawnie odmieniony w składni zgody (nie wyznaczałam żadnych poziomów pośrednich), tak więc liczba błędnie i poprawnie odmienionych przymiotników daje w sumie 100\% wszystkich przymiotników użytych przez badanych. Skupienie się na błędach było poza tym podyktowane względami ekonomicznymi wynikającymi $\mathrm{z}$ faktu, że błędnie odmienionych przymiotników jest po prostu mniej w korpusie niż odmienionych poprawnie. U polskojęzycznych uczących się błędy w kongruencji przymiotników wynoszą 7,4\%. 
Rozdział piąty rozprawy zawiera analizę danych, której wyniki są omówione w szóstym i ostatnim rozdziale pracy. Z analizy wynika, że kongruencja przymiotników w języku norweskim jako L2 jest ogólnie rzecz biorąc dobrze przyswojona przez badanych, gdyż poziom poprawności ich performancji wynosi 92,6\%. Polskojęzyczni uczący się użyli przymiotników w wielu różnych rodzajach fraz, z których niektóre pojawiały się dość często (np. frazy nominalne $\mathrm{z}$ przymiotnikiem jako przydawką), podczas gdy inne były rzadkie (np. frazy nominalne z przymiotnikiem jako przydawką po rzeczowniku w dopełniaczu lub zaimku dzierżawczym). Sukces w kongruencji przymiotników wśród badanych zależał w dużej mierze od prawidłowego rozpoznania kontekstu kongruencji. Jeśli chodzi o odmianę przymiotnika w liczbie mnogiej, to zauważyłam częstsze występowanie takich błędów w przypadku orzeczników niż przydawek ( 49 w stosunku do 21 wystąpień), co może być spowodowane na przykład ograniczeniami operacyjnymi w przetwarzaniu informacji u uczących się (processability) spowodowanymi odległością między wyrazem nadrzędnym a orzecznikiem (por. Glahn et.al. 2001, Lichtman 2009, Pienemann 2003). Przewaga błędów w pozycji orzecznikowej może być również spowodowana niewystępowaniem kongruencji orzeczników w liczbie mnogiej w niektórych norweskich dialektach, na przykład w Nord-Norge i w Bergen (Papazian \& Helleland 2012: 123, Vigeland 1995: 37), co z kolei musi wpływać na input, jaki dostają uczący się języka norweskiego mieszkający na tych obszarach.

Ponadto stwierdziłam, że wiele błędów, które uczący się popełnili w kongruencji, jest spowodowane nieprzyswojeniem sobie rodzajów rzeczowników, które trzeba opanować. W wielu przypadkach do rzeczowników dopisano błędny rodzaj, co również wpłynęło na odmianę przymiotników. Podobna sytuacja ma miejsce $\mathrm{w}$ przypadku określonych fraz nominalnych. Częstym zjawiskiem jest brak odmiany przymiotników w takich frazach, co jest błędem - zresztą niejedynym popełnianym w określonych frazach nominalnych (gdzie często brakuje 
również rodzajnika określonego lub formy określonej rzeczownika). Moja konkluzja jest zatem taka, że pełna akwizycja kongruencji przymiotnika w języku norweskim nie jest możliwa bez uprzedniego przyswojenia kategorii rodzaju i określoności.

Niektóre konstrukcje gramatyczne zawierające przymiotniki sprawiają wrażenie unikanych przez uczących się, co zgodnie z klasyfikacją transferu przez Odlina (1989: 36) może być wynikiem oddziaływania transferu negatywnego - w tym przypadku to jedynie niepotwierdzona jeszcze hipoteza. Konstrukcjami, które można uznać za unikane, podejrzane o bycie unikanymi są w przypadku polskojęzycznych uczących się: frazy nominalne $\mathrm{z}$ przymiotnikiem jako przydawką po rzeczowniku w dopełniaczu lub zaimku dzierżawczym, rzeczowniki w składni zgody $\mathrm{z}$ rzeczownikami o znaczeniu generycznym, $\mathrm{z}$ frazami bezokolicznikowymi, ze zdaniami podrzędnymi z at $(=\dot{z} e)$ oraz po czasownikach føle seg i se ut (= czuć się, wyglądać).

Polskojęzyczni uczący się norweskiego popełniali błędy w kongruencji przymiotników, niezależnie od paradygmatu odmiany, do którego należały przymiotniki. Nie można zatem stwierdzić, że tak zwany zmodyfikowany wzorzec odmiany lub nieregularny wzorzec odmiany przymiotników wpływają negatywnie na użycie przymiotników w składni zgody.

Z czynników społecznych, których wpływ na akwizycję kongruencji przebadałam, jedynie ogólny poziom biegłości językowej mierzony w skali CEFR koreluje z poprawnością $\mathrm{w}$ zakresie kongruencji przymiotników. Wraz z rosnącym poziomem umiejętności językowych w norweskim uczący się popełniali coraz mniej błędów w badanej kompetencji językowej. Przełomowy okazał się poziom B2. Uczący się dysponującymi kompetencjami językowymi na tym lub na wyższym poziomie posługiwali się kongruencją istotnie poprawniej niż uczący się znajdujący się na poziomie B1 i niższych. Pozostałe czynniki, to jest wiek, wykształcenie, liczba godzin kursu językowego, długość pobytu w Norwegii, znajomość języka angielskiego 
jako L3, nie miały wpływu na akwizycję kongruencji norweskich przymiotników.

Z przeprowadzonych badań wynika, że transfer stanowi czynnik wpływający pozytywnie na poprawność odmiany przymiotników w grupie polskiej. Grupa ta charakteryzuje się zarówno homogenicznością i heterogenicznością w stosunku do grupy angielskiej (polskojęzyczni robią statystycznie istotnie mniej błędów niż angielskojęzyczni) i nie wykazuje różnic w odmianie przydawek i orzeczników (istniejące różnice nie są statystycznie istotne i mogły powstać przypadkowo), co oznacza że obserwacje wewnątrzgrupowej homogeniczności, międzygrupowej heterogeniczności i wewnątrzjęzykowego kontrastu zostały potwierdzone. Obserwacje międzyjęzykowej zgodności w performancji nie zostały w pełni potwierdzone $\mathrm{w}$ tej grupie L1 (ani zresztą w żadnej innej), gdyż jedynie część błędów wykazuje zgodność z performancją w L1.

Ponadto stwierdziłam występowanie transferu negatywnego u angielskojęzycznych badanych, którzy podobnie do polskojęzycznych spełniają w pełni trzy z czterech kryteriów transferu, podczas gdy kryterium międzyjęzykowej zgodności w performancji spełnione jest jedynie częściowo. W przypadku grupy niemieckojęzycznej stwierdziłam występowanie transferu pozytywnego w kongruencji przydawek i transferu negatywnego w kongruencji orzeczników. Grupa ta różni się od dwóch pozostałych jedynie kryterium kontrastu wewnątrzjęzykowego. Okazuje się, że niemieckojęzyczni uczący się statystycznie istotnie bardziej poprawnie odmieniają przydawki w składni zgodny niż w funkcji orzecznika, co właśnie świadczy o występowaniu transferu językowego w tej grupie.

Rozdział szósty kończę wnioskami, które mogą być przydatne do celów dydaktycznych i stanowią propozycję dalszych badań nad akwizycją kongruencji przymiotników w języku norweskim jako L2. Po niespełna 20 latach badań nad akwizycja języka norweskiego jako L2 nie udało się jeszcze wyjaśnić jej wszystkich aspektów. Wyniki moich badań mogą przyczynić się bezpośrednio do ogólnego opisu akwizycji 
języka norweskiego, co jest konieczne ze względu na coraz większe zaangażowanie społeczeństwa norweskiego w kontakty z innymi społeczeństwami i związaną z tym potrzebą dwujęzyczności. 


\section{Litteratur}

Andersen, Roger. 1983. Transfer to somewhere. I: Gass, Susan M. \& Larry Selinker (red.) Language transfer in language learning. Rowley, Massachusetts: Newbury House, ss. 177-201.

Andersen, Roger. 1984. The one-to-one principle of interlanguage construction. I: Language Learning 34, ss. 77-95.

Andersen, Roger. 1990. Models, processes, principles and strategies: second language acquisition inside and outside the classroom. I: B. VanPatten Bill \& James F. Lee (red.) Second Language Acquisition-Foreign Language Learning. Clevedon, UK: Multilingual Matters, ss. pp. 45-78.

Anderssen, Marete. 2007. The Acquisition of Compositional Definiteness in Norwegian. I: Anderssen, Merete \& Marit Westergaard (red.): Papers from the Language Acquisition Workshop, SCL 2006, Nordlyd 34 (3), ss. 252-275.

Anward, Jan. 2000. A dynamic model of part-of-speech differentiation. I: Petra M. Vogeland Bernard Comrie (red.) Approaches to the typology of word classes. (Empirical Approaches to Language Typology 23.) Berlin / New York: Mouton de Gruyter, ss. 3-45.

Awedykowa, Sława. 1976. Gramatyka opisowa języka norweskiego (bokmål) $w$ zarysie. Poznań: Wydawnictwo Naukowe Uniwersytetu im. Adama Mickiewicza w Poznaniu.

Axelsson, Monica. 1994. Noun phrase development in Swedish as a second language. A study of adult learners acquiring definiteness and the semantics and morphology of adjectives. Stockholm University: Centre for Research on Bilingualism.

Baayen, R. H. 2008. Analyzing Linguistic Data. A Practical Introduction to Statistics Using R. Cambridge: Cambridge University Press.

Bardovi-Harlig, Kathleen. 1987. Markedness and salience in secondlanguage acquisition. Language Learning 37, ss. 385-407.

Bartning, Inge. 2000. Gender agreement in L2 French: Pre-advanced vs advanced learners. I: Studia Linguistica, 54 (2). Special Issue: A selection of papers from EUROSLA 9, Lund, Sweden, June 10-12, 1999, ss. 225-237.

Berggreen, Harald \& Kari Tenfjord. 1999. Andrespråkslcering. Oslo: Ad Notam Gyldendal. 
Berulfsen, Bjarne. 1967. Norsk grammatikk: ordklassene. Oslo: Aschehoug.

Bhat, Darbhe Narayana Shankara. 1994. The Adjectival Category: criteria for differentiation and identification. Amsterdam: John Benjamins Publishing Company.

Birdsong, David. 1999. Introduction: whys and why nots of the Critical Period Hypothesis for second language acquisition. I: Birdsong, David (red.) Second Language Acquisition and the Critical Period Hypothesis. Mahwah, NJ: Lawrence Erlbaum Associates, ss. 1-22.

Bley-Vroman, Robert. 1983. The Comparative Fallacy in Interlanguage Studies: The Case of Systematicity. I: Language Learning. A Journal of Applied Linguistics, 2006, vol. 33/1, ss. $1-17$.

Bley-Vroman, Robert. 1988. The fundamental character of foreign language learning. I: Rutherford, William \& Michael Sharwood Smith. (red.) Grammar and second language teaching: A book of readings. New York: Newbury House, ss. 19-30.

Bock, Kathryn, \& Carola A. Miller. 1991. Broken Agreement. Cognitive Psychology 23, ss. 45-93.

Bokmålsordboka. Definisjons- og rettskrivningsordbok. 2005. Boye Wangensteen (red.). 3. utg. Oslo: Kunnskapsforlaget.

Cantos Gómez, Pascual. 2013. Statistical methods in language and linguistic research. Sheffield: Equinox Publishing Ltd.

Carlsen, Cecilie. 2010. A knytte ASK til Rammeverket - hvorfor og hvordan. I: Johansen, Hilde, Anne Golden, Jon Erik Hagen \& Ann-Kristin Helland (red.). Systematisk, variert, men ikke tilfeldig. Antologi om norsk som andrespråk $i$ anledning Kari Tenfjords 60-årsdag. Oslo: Novus Forlag, ss. 131-147.

Carter, Ronald \& Michael McCarthy. 2006. Cambridge grammar of English: a comprehensive guide. Spoken and written English grammar and usage. Cambridge: Cambridge University Press.

Cenoz, Jasone. 2001. The Effect of Linguistic Distance, L2 Status and Age on Cross-linguistic Influence in Third Language Acquisition. I: Cenoz, Jasone, Britta Hufeisen \& Ulrike Jessner. Cross-linguistic Influence in Third Language Acquisition Psycholinguistic Perspectives. Clevedon / Buffalo / Toronto / Sydney: Multilingual Matters Ltd, ss. 8-20.

Chomsky, Noam. 1965. Aspects of the theory of syntax. Cambridge, Mass.: M.I.T. Press. 
Corbett, Greville G. 2001 (1. utg. i 1998). Morphology and Agreement. I: Spencer, Andrew \& Arnold M. Zwicky (red.): The Handbook of Morphology. Oxford: Blackwell Publishers, ss. 191-205.

Corbett, Greville G. 2006. Agreement. Cambridge: Cambridge University Press.

Corder, Pit. 1967. The significance of learner's errors. International review of applied linguistics in language teaching 5, ss. 161-170.

Croft, William. 1991. Syntactic categories and grammatical relations: the cognitive organization of information. Chicago: The University of Chicago Press.

Cruse, Alan. 2000. Meaning in Language. An Introduction to Semantics and Pragmatics. Oxford: Oxford University Press.

Dalgaard, Peter. 2008. Introductory Statistics with R. Second Edition. New York: Springer.

DeKeyser, Robert. 2003. Implicit and Explicit Learning. I: Doughty, Catherine J. \& Michael H. Long (red.) The Handbook of Second Language Acquisition. Singapore: Blackwell Publishing, ss. 313-348.

Dewaele, Jean.-Mark. \& Daniel Veronique. 2000. Relating gender errors to morphosyntax and lexicon in advanced French interlanguage. I: Studia Linguistica 54 (2), ss. 212-224.

Dixon, Robert M.W. 1982. Where have all the adjectives gone? I: Where have all the adjectives gone? - and other essays in Semantics and Syntax. De Gruyter Mouton, Canberra, ss. 1-62.

Dörnyei, Zoltán \& Peter Skehan. 2003. Individual Differences in Second Language Learning. I: Doughty, Catherine J. \& Michael H. Long (red.) The Handbook of Second Language Acquisition. Singapore: Blackwell Publishing, ss. 589-630.

Doroszewski, Witold. 1963. Podstawy gramatyki polskiej. Część I. 2. utg. Warszawa: Państwowe Wydawnictwo Naukowe.

Doughty, Catherine J. \& Michael H. Long 2003a. SLA and Cognitive Science. I: Doughty, Catherine J. \& Michael H. Long (red.) The Handbook of Second Language Acquisition. Singapore: Blackwell Publishing, ss. 866-870.

Doughty, Catherine J. \& Michael H. Long. 2003b. The Scope of Inquiry and Goals of SLA. I: Doughty, Catherine J. \& Michael H. Long (red.) The Handbook of Second Language Acquisition. Singapore: Blackwell Publishing, ss. 3-16. 
Duden. 2005. Die Grammatik - Unentbehrlich für richtiges Deutsch. 7., völlig neu erarbeitete und erweiterte Auflage (Band 4 - Der Duden in 12 Bänden); hrsg. von der Dudenredaktion; Dudenverlag; Mannheim, Leipzig, Wien, Zürich.

Dulay, Heidi, Marina Burt, \& Stephen Krashen. 1982. Language two. Oxford: Oxford UniversityPress.

Ellis, Nick C. 1994. Implicit and explicit language learning - an overview. I: Ellis, Nick C. (red.). Implicit and Explicit Learning of Languages. London: Academic Press, ss. 1-31.

Ellis, Nick C. 1997. Vocabulary acquisition: Word structure, collocation, grammar, and meaning. I: M. McCarthy \& N. Schmidt (red.): Vocabulary: description, acquisition and pedagogy. Cambridge: Cambridge University Press, ss. 122-139.

Ellis, Nick C. 2006. SLA: The Associative Cognitive CREED. I: VanPatten Bill \&Jessica Williams (red.). Theories in second language acquisition: An introduction. Mahwah NJ: Erlbaum, ss.100-121.

Ellis, Nick C. 2008. Usage-based and form-focused language acquisition: The associative learning of constructions, learned attention, and the limited L2 endstate. I: Ellis Nick C. \& Peter Robinson (red.): The Handbook of Cognitive Linguistics and Second Language Acquisition. New York: Routledge, ss. 372-405.

Ellis, Rod. 1994. The study of second language acquisition. Oxford: Oxford University Press.

Ellis, Rod. 2012. Second Language Acquisition. (1. utg. 1997). Oxford: Oxford University Press.

Engel, Ulrich. 1996. Deutsche Grammatik. 3., korrigierte, Auflage. Heidelberg: Groos.

Engen, Thor Ola \& Lars Anders Kulbrandstad. 2004. Tospråklighet, minoritetsspråk og minoritetsundervisning. Oslo: Gyldendal.

Evans, Vyvyan \& Melanie Green. 2011. Cognitive linguistics. An introduction (First published 2006). Edinburgh: Edinburgh University Press.

Faarlund, Jan Terje. 1988. Morfologi. Bøyningssystemet $i$ nynorsk og bokmål. Oslo Det Norske Samlaget.

Faarlund, Jan Terje, Svein Lie \& Kjell Ivar Vannebo. 1997. Norsk referansegrammatikk. Oslo: Universitetsforlaget.

Færch, Claus \& Gabriele Kasper. 1980. Processes in foreign language learning and communication. Interlanguage Studies Bulletin 5, ss. $47-118$. 
Field, Andy. 2011. Discovering statistics using SPSS. 3. utg. London: Sage.

Flege, James Emil, David Birdsong, Ellen Bialystok, Molly Mack, Hyekyung Sung, Kimiko Tsukada. 2006. Degree of foreign accent in English sentences produced by Korean children and adults. I: Journal of Phonetics 34, ss. 153-175.

Franceschina, Florencia. 2005. Fossilized Second Language Grammars: the Acquisition of Grammatical Gender. Amsterdam: John Benjamins.

Friberg, Jon Horgen \& Anne Golden. 2014. Norges største innvandrergruppe: Historien om migrasjon fra Polen til Norge og om andrespråkskorpuset ASK. I: NOA norsk som andrespråk 2, ss. 11-23.

Friedman, Debra A. 2012. How to Collect and Analyze Qualitative Data. I: Granger, Sylviane, Joseph Hung, \& Stephanie PetchTyson (red.) Computer Learner Corpora, Second Language Acquisition and Foreign Language Teaching. Amsterdam \& Philadelphia: Benjamins, ss. 180-200.

Garbacz, Piotr. 2014. Dialekter i Norge og i Polen - forskjellig status? I: NOA norsk som andrespråk 2, ss. 24-39.

Garman, Michael. 1990. Psycholinguistics. Cambridge: Cambridge University Press.

Gass, Susan. 2003. Input and Interaction. I: Doughty, Catherine J. \& Michael H. Long (red.) The Handbook of Second Language Acquisition. Singapore: Blackwell Publishing, ss. 224-255.

Gass, Susan M. \& Alison Mackey. 2002. Frequency effects and second language acquisition: A complex picture? I: Studies in Second Language Acquisition 24 (2), ss. 249-260.

Gass, Susan M. \& Larry Selinker. 1994. Second language acquisition: an introductory course. New York: Routledge.

Gass, Susan M., \& Larry Selinker. 2008. Second language acquisition: an introductory course (1. utg. 1994). New York: Routledge.

Glahn, Esther, Gisela Håkansson, Björn Hammerberg, Anne Holmen, Anne Hvenekilde \& Karen Lund. 2001. Processability in Scandinavian second language acquisition. I: Studies in Second Language Acquisition 23 (3), ss. 389-416.

Golden, Anne \& Kari Tenfjord. 2014. Møte mellom polsk og norsk i Norge. I: NOA norsk som andrespråk 2, ss. 5-10. 
Golden, Anne, Kirsti Mac Donald \& Else Ryen. 2014. Norsk som fremmedspråk. Grammatikk. Oslo: Universitetsforlaget.

Golden, Anne, Lise Iversen Kulbrandstad \& Kari Tenfjord. 2007. Norsk andrespråksforskning - utviklingslinjer fra 1980 til 2005. Nordand 2 (1), ss. 5-41.

Golden, Anne. 2009. Ordforråd, ordbruk og ordlaring. 3. utgave. Oslo: Gyldendal Akademisk.

Goldschneider, Jennifer M. \& Robert M. DeKeyser. 2005. Explaining the "Natural order of L2 morpheme acquisition" in English: a meta-analysis of multiple determinants. Language Learning, 55, ss. $1-50$.

Granger, Sylviane. 2002. A bird's eye view of learner corpus research. I: Granger, Sylviane, Joseph Hung, \& Stephanie Petch-Tyson (red.) Computer Learner Corpora, Second Language Acquisition and Foreign Language Teaching. Amsterdam \& Philadelphia: Benjamins, ss. 3-33.

Granger, Sylviane. 2012. How to Use Foreign and Second Language Learner Corpora. I: Mackey, Alison \& Susan M. Gass (red.) Research Methods in Second Language Acquisition. A Practical Guide. Chichester: Wiley-Blackwell, ss. 7-29.

Greenbaum, Sidney \& Randolph Quirk. 1990. A student's grammar of the English language. Harlow: Longman.

Gregg, Kevin R. 2003. SLA Theory: Construction and Assessment. I: Doughty, Catherine J. \& Michael H. Long (red.) The Handbook of Second Language Acquisition. Singapore: Blackwell Publishing, ss. 831-865.

Guion, Susan G., James E. Flege \& Jonathan D. Loftin. 2000a. The effect of L1 use on pronunciation in Quichua-Spanish bilinguals. I: Journal of phonetics 28 (1), ss. 27-42.

Guion, Susan G., James E. Flege, Serana H. Liu \& Grace H. YeniKomshian. 2000b. Age of learning effects on the duration of sentences produced in a second language. Applied Psycholinguistics 21, ss. 205-228.

Hagen, Jon Erik 1992. Feilinvertering, overinvertering og underinvertering. I: NOA. Norsk som andrespråk 15, ss. 27-38.

Hagen, Jon Erik. 1998. Norsk grammatikk for andrespråkslcerere. Oslo: Gyldendal Akademisk.

Hammarberg, Björn \& Sarah Williams. 2009. A study of third language acquisition. I: Hammarberg, Björn. Processes in Third 
Language Acquisition. Edinburgh: Edinburgh University Press, ss. 17-27.

Hammarberg, Björn. 1996. Examining the processability theory: The case of adjective agreement in L2 Swedish. I: Kellerman, Eric, Bert Weltens, \& Theo Bongaerts (red.), EUROSLA 6: A Selection of papers. Toegepaste taalwetenschap in artikelen 55. Amsterdam: Ane'la.

Hammarberg, Björn. 2001. Roles of L1 and L2 in L3 Production and Acquisition. I: Cenoz, Jasone, Britta Hufeisen \& Ulrike Jessner. Cross-linguistic Influence in Third Language Acquisition Psycholinguistic Perspectives. Clevedon / Buffalo / Toronto / Sydney: Multilingual Matters Ltd, ss. 21-41.

Haskell, Todd \& Maryellen MacDonald. 2005. Constituent Structure and Linear Order in Language Production: Evidence from Subject-Verb Agreement. Journal of Experimental Psychology: Learning, Memory, and Cognition 31 (5).

Helbig, Gerhard \& Joachim Buscha. 2001. Deutsche Grammatik. Ein Handbuch für den Ausländerunterricht. Berlin, München: Langenscheidt.

Helland Gujord, Ann-Kristin. 2013. Grammatical encoding of past time in L2 Norwegian. The roles of L1 influence and verb semantics. Avhandling for dr.art.-graden, Universitetet i Bergen.

Hofherr, Patricia Cabredo. 2010. Adjectives. An introduction. I: Hofherr, Patricia Cabredo \& Ora Matushansky (red.): Adjectives. Formal analyses in syntax and semantics. Amsterdam: John Benjamins.

Hulstijn, Jan H. 2005. Theoretical and empirical issues in the study of implicit and explicit second-language learning: Introduction. I: Studies in Second Language Acquisition 27, ss. 129-140.

Hyltenstam, Kenneth. 1977. Implicational patterns in interlanguage syntactic variation. I: Language Learning 27 (2), ss. 383-411.

Hyltenstam, Kenneth. 1984. The use of typological markedness conditions as predictors in second language acquisition: The case of pronominal copies in relative clauses. I: Andersen, Roger (red.) Second Languages: A cross-linguistic perspective, Rowley, Mass: Newbury House Publishers, ss. 39-58.

Jahr, Ernst Håkon \& Karol Janicki. 1995. The function of the standard variety: a contrastive study of Norwegian and Polish. I: International Journal of the Sociology of Language 115, ss. 25-45. 
Jahr, Ernst Håkon \& Mæhlum, Brit (red.). 2009. Norsk lingvistisk tidsskrift 27 [temahefte om standardtalemål].

Janik, Marta Olga. 2013. Hva er et adjektiv? Et forsøk på en kognitivdefinisjon. I: Folia Scandinavica Posnaniensia (15), ss. $15-30$.

Jarvis, Scott. 2000. Methodological Rigor in the Study of Transfer: Identifying L1 Influence in the Interlanguage Lexicon. I: Language Learning 50 (2), ss. 245-309.

Jarvis, Scott. 2010. Comparison-based and detection-based approaches to transfer research. I: L. Roberts, M. Howard, M. Ó Laoire, \& D. Singleton (red.), EUROSLA Yearbook 10. Amsterdam: Benjamins, ss. 169-192.

Jarvis, Scott \& Aneta Pavlenko. 2008. Crosslinguistic influence in language and cognition. New York: Routledge.

Jarvis, Scott \& Terence Odlin. 2000. Morphological type, spatial reference, and language transfer. Studies in second language acquisition 22, ss. 535-556.

Johansen, Hilde, Anne Golden, Jon Erik Hagen \& Ann-Kristin Helland (red.). 2010. Systematisk, variert, men ikke tilfeldig. Antologi om norsk som andrespråk i anledning Kari Tenfjords 60-årsdag. Oslo: Novus Forlag.

Johansen, Hilde. 2008. Inversjon i norsk innlærerspråk En undersøkelse av variasjonsmønstre i skrevne tekster. I: NOA. Norsk som andrespråk 24 (2), ss. 50-71.

Kahneman, Daniel. 1973. Attention and effort. Englewood Cliffs, NJ: Prentice Hall.

Kellerman, Eric. 1979. Transfer and non-transfer: where we are now. Studies in Second Language Acquisition 2, ss. 37-57.

Kellerman, Eric. 1983. Now you see it, now you don't. I: Gass, Susane \& Larry Selinker (red.). Language Transfer in Language Learning. Rowley, MA: Newbury House, ss. 112-134.

Kellerman, Eric. 1995. Crosslinguistic influence: Transfer to nowhere? I: Annual Review of Applied Linguistics 15, ss. 125-150.

Klemensiewicz, Zenon. 2001. Podstawowe wiadomości z gramatyki języka polskiego. 15. utg. Warszawa: Wydawnictwo Naukowe PWN.

Kløve, Marit Helene. 1997. Second language syllabification: elements of a prosodic theory based on the acquisition of Norwegian by Cantonese speakers. Avhandling for dr.art.-graden, Universitetet i Bergen. 
Krashen, Stephen. 1982. Principles and Practice in Second Language Acquisition. London: Pergamon.

Krashen, Stephen. 1985. The Input Hypothesis: Issues and Implications. New York: Longman.

Kulbrandstad, Lars Anders. 2012. Språkets mønstre. Grammatiske begreper og metoder. 3. utg. Oslo: Universitetsforlaget.

Lado, Robert. 1957. Linguistics across Cultures. Ann Arbor: University of Michigan Press.

Lakoff, George. 1987. Women, fire, and dangerous things: What categories reveal about the mind. Chicago: Chicago University Press.

Leech, Geoffrey \& Jan Svartvik. 2013. A communicative grammar of English. 3. utg. Routledge.

Lennenberg, Eric. 1967. Biological foundations of language. New York: John Wiley.

Lichtman, Karen. 2009. Acquisition of Attributive and Predicative Adjective Agreement in L2 Spanish. I: Bowles, Melissa mfl. (red.) Proceedings of the 10th Generative Approaches to Second Language Acquisition Conference (GASLA 2009). Somerville, MA: Cascadilla Proceedings Project, ss. 231-247.

Lie, Svein. 1979. Innføring $i$ norsk syntaks. Oslo, Bergen, Tromsø: Universitetsforlaget.

Lightbown, Patsy. 1983. Exploring relationships between developmental and instructional sequences in L2 acquisition. I: Seliger Herbert W. \& Michael H. Long (red.) Classroom Oriented Research in Second Language Acquisition. Rowley, MA: Newbury House, ss. 217-243.

Long, Michael. 1996. The Role of the Linguistic Environment In Second Language Acquisition. I: Ritchie, William C. \& Tej K. Bhatia (red.) Handbook of Second Language Acquisition. San Diego, CA: Academic Press, ss. 413-468.

Lyons, John. 1971. Introduction to Theoretical Linguistics. Cambridge: Cambridge University Press.

MacKay, Ian \& James Emil Flege. 2004. Effects of the age of secondlanguage (L2) learning on the duration of L1 and L2 sentences: The role of suppression. I: Applied Psycholinguistics 25, ss. 373-396. McEnery, Tony \& Andrew Hardie. 2012. Corpus Linguistics: Method, Theory and Practice. Cambridge: Cambridge University Press. McLaughlin, Barry. 1990. Restructuring. Applied Linguistics 11, ss. $113-128$. 
McNally, Louise \& Christopher Kennedy. 2008. Introduction. I: McNally, Louise \& Christopher Kennedy (red.): Adjectives and Adverbs. Syntax, Semantics, and Discourse. Oxford: Oxford University Press.

Milewski, Tadeusz. 1965. Językoznawstwo. 4. utg. Warszawa: Wydawnictwo Naukowe PWN.

Moravcsik, Edith. 1988. Agreement and markedness. I: Barlow, Michael \& Charles A. Ferguson (red.): Agreement in Natural Language: Approaches, Theories, Descriptions. Stanford: CSLI, ss. $86-106$.

Nagórko, Alicja. 2007. Zarys gramatyki polskiej (ze stowotwórstwem). Warszawa: Wydawnictwo Naukowe PWN.

Nayak, Nandini, Nina Hansen, Nancy Krueger \& Barry McLaughlin. 1990. Language learning strategies in monolingual and multilingual adults. I: Language Learning 40 (2), ss. 221-244.

Nistov, Ingvild. 2001. Referential choice in L2 narratives: a study of Turkish adolescent immigrants learning Norwegian. Avhandling for dr.art.-graden, Universitetet i Oslo.

Nordanger, Marte. 2009. Keiserens nye kloer? Lingvistisk og konseptuell transfer $i$ markeringen av grammatikalisert definitt referanse i russiskspråklige og engelskspråkliges norske mellomspråk en studie basert på ASK. Masteroppgave, Institutt for lingvistiske, litterære og estetiske studier, Universitetet i Bergen.

Norris, John M., Lourdes Ortega. 2000. Effectiveness of L2 Instruction: A Research Synthesis and Quantitative Metaanalysis. I: Language learning 50 (3), ss. 417-528.

NRG 1997. Se: Faarlund, Jan Terje, Svein Lie \& Kjell Ivar Vannebo. 1997.

Næss, Åshild. 2011. Global grammatikk. Språktypologi for språklaerere. Oslo: Gyldendal akademisk.

Oakes, Michael P. 1998. Statistics for Corpus Linguistic. Edinburgh: Edinburgh University Press.

Odlin, Terence. 1989. Language transfer: cross-linguistic influence in language learning. Cambridge: Cambridge University Press.

Odlin, Terence. 2003. Cross-Linguistic Influence. I: Doughty, Catherine J. \& Michael H. Long (red.) The Handbook of Second Language Acquisition. Singapore: Blackwell Publishing, ss. 436-486.

Odlin, Terence \& Scott Jarvis. 2004. Same Source, Different Outcomes: A Study of Swedish Influence on the Acquisition of 
English in Finland. I: International Journal of Multilingualism 1 (2), ss. $123-140$.

Olshtain, Elite, Elana Shohamy, Judy Kemp \& Rivka Chatow. 1990.

Factors Predicting Success in EFL among Culturally Different

Learners. I: Language Learning 40 (1), ss. 23-44.

Ortega, Lourdes. 2013. Understanding second language acquisition

(1. utg. 2009). New York: Routledge.

Papazian, Eric \& Botolv Helleland. 2012. Norsk talemål. Lokal og sosial variasjon. Kristiansand: Høyskoleforlaget.

Pavlenko, Aneta. 2000. L2 Influence on L1 in Late Bilingualism.

I: Issues in applied linguistics 11 (2), ss. 175-205.

Pienemann, Manfred \& Hakansson, Gisela. 1999. A Unified Approach toward the Development of Swedish as L2:

A Processability Account. I: Studies in Second Language Acquisition 21, ss. 383-420.

Pienemann, Manfred, Bruno Di Biase, Satomi Kawaguchi \& Gisela Håkansson. 2005a. Processability, typological distance and L1 transfer. I: Pienemann, Manfred (red.) Cross-linguistic aspects of processability theory. Amsterdam/New York: John Benjamins Publishing Company, ss. 85-116.

Pienemann, Manfred, Bruno Di Biase, Satomi Kawaguchi \& Gisela Håkansson. 2005b. Processing Constraints on L1 Transfer. I: de Groot, Annette M. B. \& Judith F. Kroll (red.): Handbook of Bilingualism: Psycholinguistic Approaches. Oxford: Oxford University Press, ss. 128-153.

Pienemann, Manfred. 1998. Language processing and second language development; Processability theory. Amsterdam: John Benjamins.

Pienemann, Manfred. 2003. Language Processing Capacity. I: Doughty, Catherine J. \& Michael H. Long (red.) The Handbook of Second Language Acquisition. Singapore: Blackwell Publishing, ss. 679-714.

Pienemann, Manfred. 2005. Discussing PT. I: Pienemann, Manfred (red.) Cross-linguistic aspects of processability theory. Amsterdam/New York: John Benjamins Publishing Company, ss. 61-83.

Rácz, Péter. 2013. Salience in Sociolinguistics: A Quantitative Approach. Berlin/Boston: Walter de Gruyter GmbH.

Ragnhildstveit, Silje. (under arbeid). Genus og transfer når norsk er andrespråk. Tre korpusbaserte studier. 
Ragnhildstveit, Silje. 2013. The concept of default gender. A discussion of its explanatory value in second language acquisition (et upublisert vitenskapsteoretisk innlegg).

Rammeverket. 2011. Se: Det felles europeiske rammeverket for språk. Læring undervisning vurdering. 2011.

Ringbom, Håkon. 2001. Lexical Transfer in L3 Production. I: Cenoz, Jasone, Britta Hufeisen \& Ulrike Jessner. Cross-linguistic Influence in Third Language Acquisition Psycholinguistic Perspectives. Clevedon / Buffalo / Toronto / Sydney: Multilingual Matters Ltd, ss. 59-68.

Rosch, Eleanor. 1978. Principles of Categorization. I: Rosch, Eleanor \& Barbara B. Lloyd, (red.), Cognition and categorization. Hillsdale, NJ: Lawrence Erlbaum, ss. 27-48.

Rowntree, Derek. 1981. Statistics without tears. An introduction for non-mathematicians. London: Penguin Books.

Rønhovd, Jarle. 1993. Norsk morfologi. Oslo: Ad Notam Gyldendal.

Salkind, Neil J. 2008. Statistics for people who (think they) hate statistics. 3. utg. Los Angeles: Sage Publications.

Saloni, Zygmunt \& Marek Świdziński. 1998. Składnia współczesnego języka polskiego. 4. utg. Warszawa: Wydawnictwo Naukowe PWN.

Sandøy, Helge. 1988. Samsvarbøying av adjektiv og perfektum partisipp i norske dialektar. I: Bjørkum, Andreas \& Arve Borg (red.): Nordiske studiar. Oslo: Universitetsforlaget, ss. 85-117.

Sandøy, Helge. 1996. Talemål. Oslo: Novus Forlag.

Sandøy, Helge \& Kari Tenfjord (red.). 2006. Den nye norsken? Nokre peilepunkt under globaliseringa. Oslo: Novus Forlag.

Schmeck, Ronald Ray. 1988. An Introduction to Strategies and Styles of Learning. I: Schmeck, Ronald Ray. Learning Strategies and Learning Styles. New York: Plenum, ss. 3-19.

Segalowitz, Norman \& Jan Hulstijn. 2005. Automaticity in Bilingualism and Second Language Learning. . I: de Groot, Annette M. B. \& Judith F. Kroll (red.): Handbook of Bilingualism: Psycholinguistic Approaches. Oxford: Oxford University Press, ss. 371-388.

Segalowitz, Norman. 2003. Automaticity and Second Languages. I: Doughty, Catherine J. \& Michael H. Long (red.) The Handbook of Second Language Acquisition. Singapore: Blackwell Publishing, ss. 382-408. 
Selinker, Larry. 1972. Interlanguage. I: International Review of Applied Linguistics in Language Teaching 10, ss. 209-231.

Selinker, Larry. 1992. Rediscovering interlanguage. London: Longman.

Sharwood Smith, Michael \& Eric Kellerman. 1989. The interpretation of second language output. I: Dechert, Hans-Wilhelm \& Manfred Raupach (red.) Transfer in language production. Norwood, NJ: Ablex, ss. 217-36.

Sinclair, John McHardy. 1992. Collins Cobuild. English Grammar. London: William Collins Sons \& Co Ltd.

Sinclair, John. 1996. EAGLES. Preliminary recommendations on Corpus Typology. Internettilgang: http://www.ilc.cnr.it/ EAGLES96/corpustyp/corpustyp.html [sist tilgang: 30.05.2015]. Slobin, Dan. 1996. From "thought and language" to "thinking for speaking”. I: Gumperz John J. \& Stephen C. Levinson (red.), Rethinking linguistic relativity. Cambridge, Cambridge UP, ss. 70-96.

Slobin, Dan. I. 1985. Crosslinguistic evidence for the LanguageMaking Capacity. I: Slobin, Dan I. (red.), The crosslinguistic study of language acquisition 2. Hillsdale, New Jersey: Lawrence Erlbaum Associates, s. 1157-1256.

Snow, Catherine \& Marian Hoefnagel-Höhle. 1978. The critical age for second language acquisition: evidence from second language learning. Child Development 49, ss. 1114-1128.

Sørland, Kjartan. 2010. Utvikling av substantivfrasar i tidleg innlærarnorsk. I: Johansen, Hilde, Anne Golden, Jon Erik Hagen \& Ann-Kristin Helland (red.). Systematisk, variert, men ikke tilfeldig. Antologi om norsk som andrespråk $i$ anledning Kari Tenfjords 60-årsdag. Oslo: Novus Forlag, ss. 78-93.

Spencer, Andrew. 1991. Morphological Theory. An Introduction to Word Structure in Generative Grammar. Oxford: Blackwell Publishers.

Stockwell, Robert, J. Donald Bowen, \& John W. Martin. 1965a. The Grammatical Structures of English and Italian. Chicago: University of Chicago Press.

Stockwell, Robert, J. Donald Bowen, \& John W. Martin. 1965b. The Grammatical Structures of English and Spanish. Chicago: University of Chicago Press.

Strutyński, Janusz. 2009. Gramatyka polska. 8. utg. Kraków: Wydawnictwo Tomasz Strutyński. 
Svendsen, Bente Ailin. 1998. Adjektivtilegnelse hos voksne innlærere med norsk som andrespråk. I: NOA Norsk som andrespråk nr. 21., ss. $82-118$.

Szymańska, Oliwia. 2010. Konseptualisering av rommet hos polske norskinnlærere - utfordringer og diagnoser. En korpusbasert studie med i og på i fokus. Avhandling for dr.art.-graden, Adam Mickiewicz Universitetet i Poznań.

Tenfjord, Kari. 1997. Å ha en fortid på vietnamesisk. En kasusstudie av fire vietnamesiske språkinnlæreres utvikling av grammatisk fortidsreferanse og perfektum. Avhandling for dr.art.-graden, Universitetet i Bergen.

Tenfjord Kari. 2004. ASK - A Computer Learner Corpus. I: Henrichsen, Peter Juel (red.) CALL for the Nordic Languages. Tools and Methods for Computer Assisted Language Learning. Copenhagen Studies in Language 30. Fredriksberg: Samfundslitteratur.

Tenfjord Kari, Jon Erik Hagen \& Hilde Johansen. 2009. Norsk andrespråkskorpus (ASK) - design og metodiske forutsetninger. I: NOA Norsk som andrespråk. $25 / 1$, ss. 52-81.

Toledo, Cecilie Carlsen. 1995. Subjektløshet og underinversjon i spanskspråklige elevers norske mellomspråk: en tilnærming til spørsmålet om UGs rolle i voksen andrespråkstilegnelse. Hovedoppgave i nordisk - Universitetet i Bergen.

Vassenden, Lars. 1993. Norsk syntaks. Bergen: Ad Notam Gyldendal. Venås, Kjell. 1990. Norsk grammatikk. Nynorsk. Oslo: Universitetsforlaget.

Viberg, Åke, 1987. Vägen till ett nytt språk. Del 1. Andraspråksinlärning i ett utvecklings-perspektiv. Stockholm: Natur och Kultur.

Vigeland, Bjørn. 1981. Dialekter i Norge. Målmerker med språkhistoriske forklaringer. Oslo: Universitetsforlaget.

Vigeland, Bjørn. 1995. Norske dialektar. Oversyn, heimfesting og normalisering. Oslo: Universitetsforlaget.

Weinreich, Uriel. 1953. Languages in Contact. New York: Linguistic Circle of New York.

White, Lydia. 2003. On the Nature of Interlanguage Representation: Universal Grammar in the Second Language. I: Doughty, Catherine J. \& Michael H. Long (red.) The Handbook of Second Language Acquisition. Singapore: Blackwell Publishing, ss. 19-42. 
Wróbel, Henryk. 2001. Gramatyka języka polskiego. Kraków: Spółka Wydawnicza "OD NOWA" s.c.

Åfarli, Tor A. \& Laila Sakshaug. 2006. Syntaks og morfologi med norsk $i$ sentrum. Oslo: Det norske samlaget. 


\section{Internettkilder}

ASK - Norsk andrespråkskorpus, internettkilde: clarino.uib.no/ask [tilgang: 28.06.2015].

ASKeladden-nettside: http://www.uib.no/fg/askeladden

[tilgang: 31.05.2015].

Det felles europeiske rammeverket for språk. Laring undervisning vurdering. 2011. Utdanningsdirektoriatet. Oversatt fra engelsk av: Stephanie Hazel Wold (originaltittel: Common European Framework of Reference for languages: Learning, Teaching, Assessment):

http://www.udir.no/Upload/Verktoy/5/UDIR_Rammeverk_sept 2011_web.pdf?epslanguage $=$ no [tilgang:: $1 \overline{4} .02 .2015]$.

Folkehøyskole-nettside: http://www.folkeuniversitetet.no/sider/test-inorsk-hoyere-niva/side-id-10068/ [tilgang: 31.05.2015].

Gil, David. 2013. Numeral Classifiers. I: Dryer, Matthew S. \& Haspelmath, Martin (red.) The World Atlas of Language Structures Online. Leipzig: Max Planck Institute for Evolutionary Anthropology. (Tilgjengelig online på: http://wals.info/chapter/55, [tilgang: 17.08.2014].

MulitLing: http://www.hf.uio.no/multiling/ [tilgang: 04.01.2015].

Oslo-Bergen-taggeren - en grammatisk tagger for bokmål og nynorsk: http://tekstlab.uio.no/obt-ny/index.html [tilgang: 31.05.2015].

R-prosjekt, internettkilde: http://www.r-project.org/about.html [tilgang: 10.05.2015].

SSB_1 - Statistisk sentralbyrå: Innvandrere og norskfødte med innvandrerforeldre, 1. januar 2015:

https://www.ssb.no/befolkning/statistikker/innvbef [tilgang:27.03.2015].

SSB_2 - Statistisk sentralbyrå: Folkemengde, innvandrere og norskfødte med innvandrerforeldre etter landbakgrunn (Eget, eventuelt mors eller fars fødeland dersom det er utenlandsk, ellers Norge.). 1970-2012. Absolutte tall og prosent: http://www.ssb.no/a/kortnavn/innvbef/tab-2012-04-26-06.html [tilgang: 27.03.2015].

SSB 3 - Statistisk sentralbyrå: Nøkkeltall for innvandring og innvandrere: https://www.ssb.no/innvandring-oginnvandrere/nokkeltall [tilgang: 27.03.2015].

SSB_4 - Statistisk sentralbyrå: Østby, Lars (red.): Innvandrere i Norge - Hvem er de, og hvordan går det med dem? Del I 
Demografi:

http://www.ssb.no/a/publikasjoner/pdf/notat_200465/notat_200 465.pdf

[tilgang: 27.03.2015].

Vox-nettside: http://www.vox.no/norskprove/\#ob=11946

[tilgang: 31.05.2015]. 


\section{Vedlegg}

\section{Oppgaven i pilotundersøkelsen}

Oppgaven var en del av en annen test andreårsstudentene ved Adam Mickiewicz Universitet i Poznań tok, og besto av 9 setninger hvor adjektivene ble tatt bort og satt i parentes i ubøyd form. Studentenes oppgave var å bøye adjektivene i samsvar med kontrolløren (kontrollørene var substantiver, pronomener eller kvantoren begge). Oppgaven var delt i to grupper: gruppe A og gruppe B:

Oppgave - gruppe A:

Sett inn adjektivene i riktig form, eventuelt med artikkel:

1. Kålrabistappe er (god)

2. (liten) .......... boka er om skyer.

3. Mannens (gammel) .......... radio kostet $90 \mathrm{kr}$.

4. Kan du vaske (skitten) ........... tallerkenene?

5. Hun liker (grå) .......... klær.

6. Er dette brødet virkelig (søt) .......... ?

7. Dette diktet er (spansk)

8. Vi er (vant) ........... til å lære masse.

9. Dere to er utrolig (lik) .......... hverandre. 
Oppgave - gruppe B:

Sett inn adjektivene i riktig form, eventuelt med artikkel:

1. Ungdomsromaner er (dum)

2. (liten) kakene koster $20 \mathrm{kr}$.

3. Guttens (ny) ........... kjæreste heter Ingvild.

4. Kan du kjøpe noen (moden) bananer?

5. Han liker ikke å gå i (blå) .......... klær.

6. Journalisten skrev et (rask) ........... svar på brevet.

7. Dette diktet er (bulgarsk)

8. Vi er (takknemlig) ........... for at vi kan lære så masse.

9. Begge to er (klar) .......... etter en så lang arbeidsdag.

Det var 21 studenter som tok testen: 11 i gruppe A, og $10 \mathrm{i}$ gruppe B. Hver student har fått et nummer som også viser hennes gruppetilhørighet. Tabell 54 viser resultatene fra testen: antall feil hver av studentene gjorde (feilskriving og mangel på artikkelen var også betraktet som feil), og Tabell 55 viser studentenes svar. 


\begin{tabular}{|l|l|l|l|}
\hline Stud_nr. & Feil & Korrekt & \% feil \\
\hline Stud_1_A & 2 & 7 & $22 \%$ \\
\hline Stud_2_A & 0 & 9 & $0 \%$ \\
\hline Stud_3_A & 0 & 9 & $0 \%$ \\
\hline Stud_4_A & 1 & 8 & $11 \%$ \\
\hline Stud_5_A & 2 & 7 & $22 \%$ \\
\hline Stud_6_A & 2 & 7 & $22 \%$ \\
\hline Stud_7_A & 1 & 8 & $11 \%$ \\
\hline Stud_8_A & 2 & 7 & $22 \%$ \\
\hline Stud_9_A & 3 & 6 & $33 \%$ \\
\hline Stud_10_A & 5 & 7 & $56 \%$ \\
\hline Stud_11_A & 3 & 6 & $33 \%$ \\
\hline Stud_1_B & 4 & 5 & $44 \%$ \\
\hline Stud_2_B & 7 & 2 & $78 \%$ \\
\hline Stud_3_B & 3 & 6 & $33 \%$ \\
\hline Stud_4_B & 2 & 7 & $22 \%$ \\
\hline Stud_5_B & 3 & 6 & $33 \%$ \\
\hline Stud_6_B & 3 & 6 & $33 \%$ \\
\hline Stud_7_B & 2 & 7 & $22 \%$ \\
\hline Stud_8_B & 4 & 5 & $44 \%$ \\
\hline Stud_9_B & 3 & 6 & $33 \%$ \\
\hline Stud_10_B & 2 & 7 & $22 \%$ \\
\hline TOTALT & 54 & 138 & $29 \%$ \\
\hline
\end{tabular}

Tabell 54: Resultater fra pilotundersøkelsen 


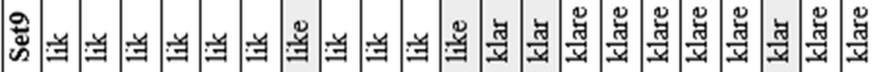

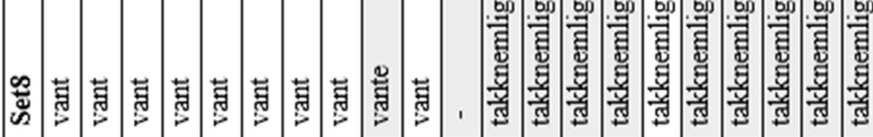

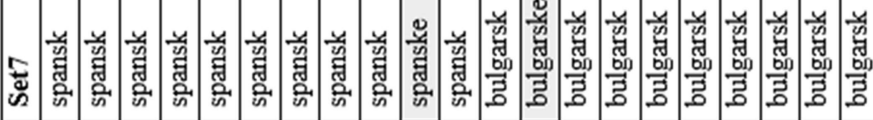

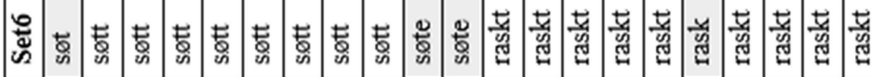

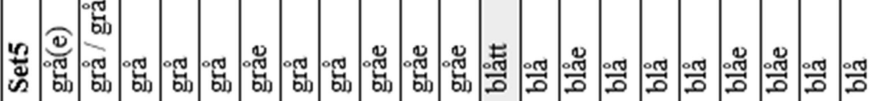

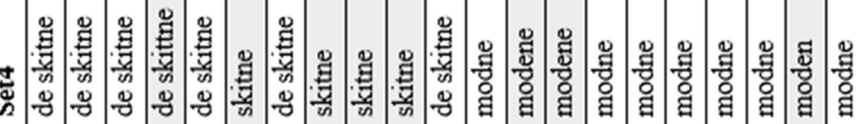

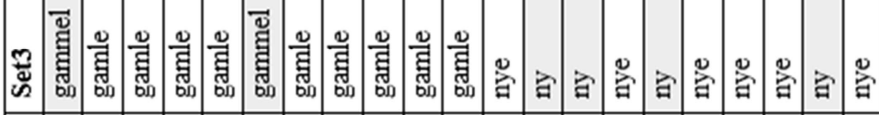

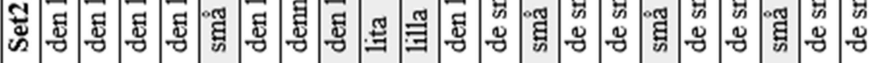

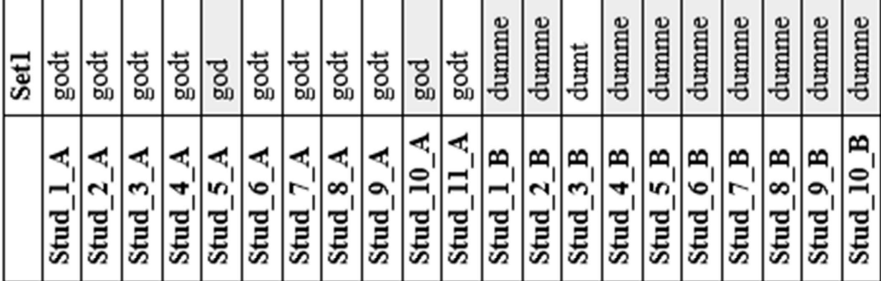

Tabell 55: Studentenes svar i pilotundersøkelsen 



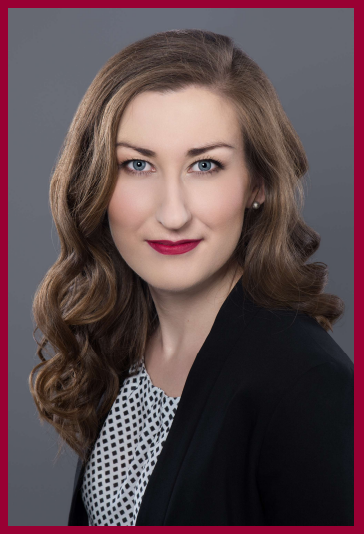

Marta Olga Janik - lingwistka specjalizująca się w języku norweskim. Jej głównym polem zainteresowań jest akwizycja języka drugiego i w ramach tej dyscypliny uzyskała stopień doktora na Uniwersytecie Adama Mickiewicza w Poznaniu. W czasie studiów, zarówno doktoranckich, jak i magisterskich, badaczka wielokrotnie przebywała w Norwegii: na Uniwersytecie NTNU w Trondheim oraz na Uniwersytecie w Bergen.

Niniejsza rozprawa, zatytułowana Adjektivbøyning $i$ norsk - kongruenstilegnelse hos polskspråklige norskinnlcerere (Odmiana przymiotnika w języku norweskim - akwizycja kongruencji przymiotnika przez polskojęzycznych uczących się języka norweskiego), jest w pewnym stopniu częścią norweskiego projektu badawczego ASKeladden (projekt został zakończony wiosną 2014 roku, a jego głównym celem było badanie wpływu transferu na przyswajanie języka norweskiego jako drugiego). Dane przedstawione i przeanalizowane w pracy zostały zebrane w trakcie rocznego pobytu na Uniwersytecie w Bergen dzięki grantowi Yggdrasil mobility programme przyznanemu przez The Research Council of Norway.

Rozprawa przedstawia proces akwizycji kongruencji norweskich przymiotników przez polskojęzycznych uczących się języka norweskiego jako drugiego. Pokazano zarówno poziom ich kompetencji w odmianie norweskich przymiotników w składni zgody oraz ustalono, jakie czynniki (spośród psycholingwistycznych, lingwistycznych i społecznych) z nią korelują. Ponadto, praca zawiera dokładny opis odmiany przymiotników w składni zgody w języku norweskim.

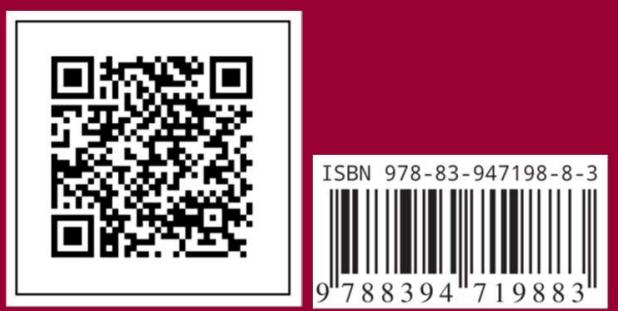

*DOI: $10.14746 / 9788394719883 *$ 